
UNIVERSIDADE DE SÃO PAULO

Instituto de Arquitetura e Urbanismo

\title{
Rios, cidade e espaços livres em Presidente Prudente - SP: a bacia hidrográfica do Córrego do Veado
}

\author{
Versão corrigida
}

GABRIEL VALENTINI FRANCISQUETI

Dissertação apresentada ao Instituto de Arquitetura e Urbanismo da Universidade de São Paulo para a obtenção do título de Mestre em Ciências.

\section{Programa}

Arquitetura e Urbanismo

Área de concentração

Teoria e História da Arquitetura e Urbanismo

Linha de Pesquisa

Arquitetura, Cidade e Paisagem no Brasil e na América Latina

Orientadora

Profa. Dra. Luciana Bongiovanni Martins Schenk 


\begin{abstract}
AUTORIZO A REPRODUCAO TOTAL OU PARCIAL DESTE TRABALHO, POR QUALQUER MEIO CONVENCIONAL OU ELETRONICO, PARA FINS DE ESTUDO E PESQUISA, DESDE QUE CITADA A FONTE
\end{abstract}

Ficha catalográfica elaborada pela Biblioteca do Instituto de Arquitetura e Urbanismo com os dados fornecidos pelo(a) autor(a)

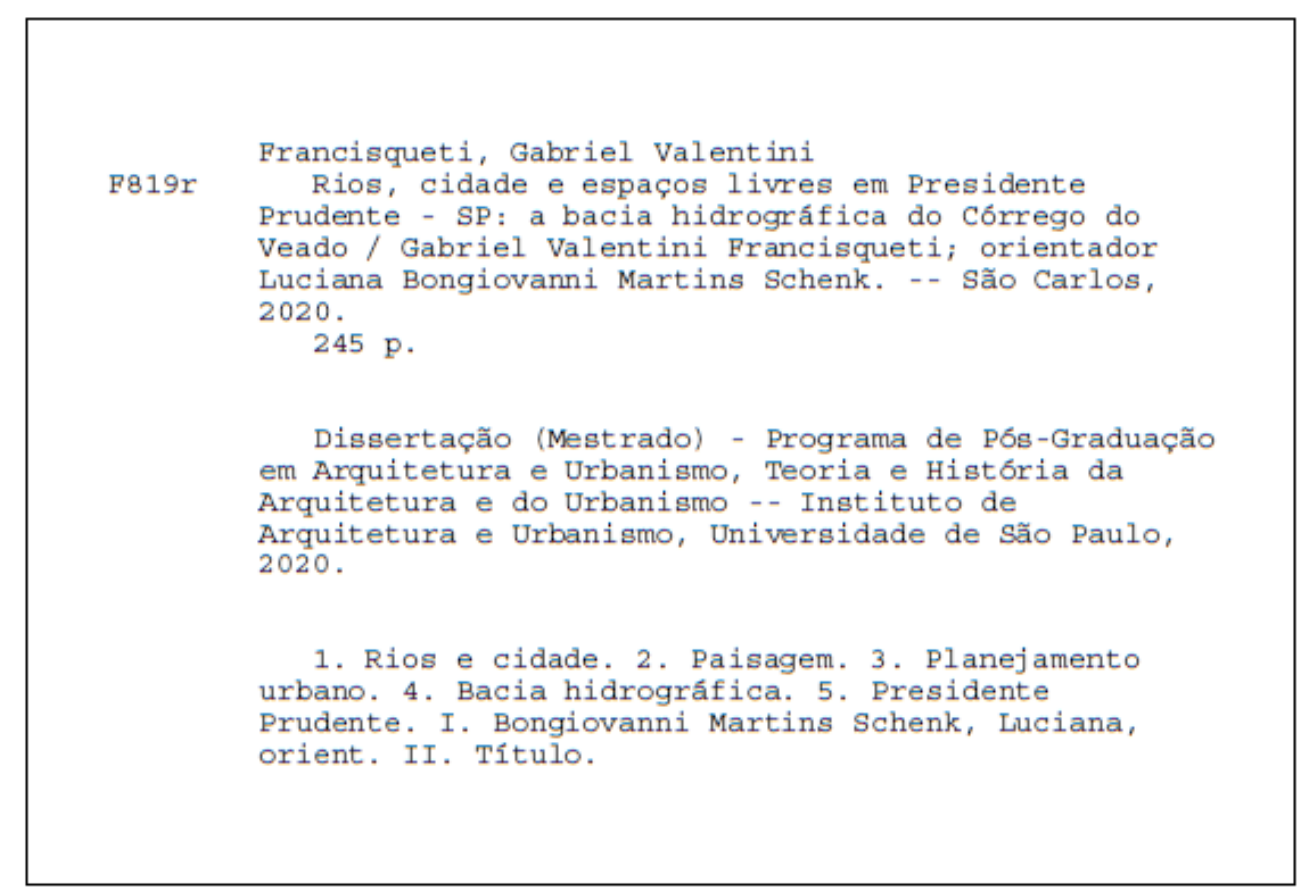

Bibliotecária responsável pela estrutura de catalogaçăo da publicaçăo de acordo com a AACR2:

Brianda de Oliveira Ordonho Sígolo - CRB - 8/8229 


\section{FOLHA DE JULGAMENTO}

Candidato(a): Gabriel Valentini Francisqueti

Título da dissertação: "Rios, Cidade e Espaços Livres em Presidente Prudente - SP: a Bacia Hidrográfica do Córrego do Veado"

Data da defesa: $21 / 05 / 2020$

Orientadora: Profa. Dra. Luciana Bongiovanni Martins Schenk

Comissão Julgadora:

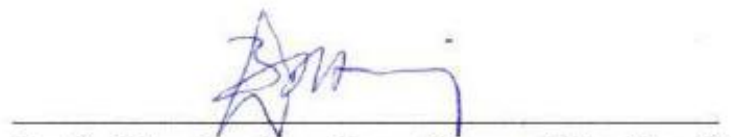

Profa. Dra. Luciana Bongiovanni Martins Schenk

(IAU/USP)

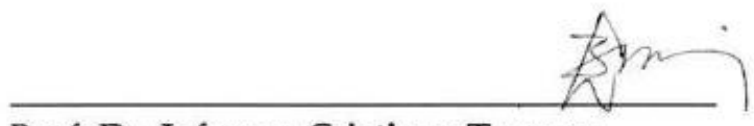

Prof. Dr. Jeferson Cristiano Tavares (IAU/USP)

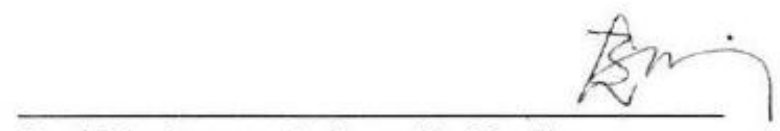

Prof. Dr. Leonardo Loyolla Coelho

(Belas Artes e Escola da Cidade)

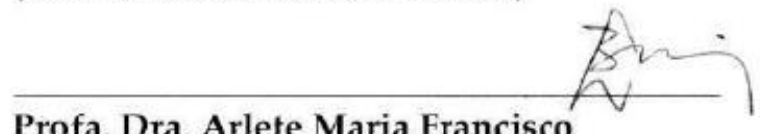

Profa. Dra. Arlete Maria Francisco

(UNESP/Presidente Prudente)
Resultado:

Não votante
Aprovado

Aprovado

Aprovado

Coordenador e Presidente da Comissão de Pós-Graduação do Programa de PósGraduação em Arquitetura e Urbanismo: Prof. Dr. Tomás Antonio Moreira. 



\section{AGRADECIMENTOS}

Agradeço a minha família, por todo apoio e suporte para que sonhos pudessem ser realizados e o presente se concretizasse.

Agradeço aos encontros que o viver nos proporciona.

Foi em um deles, ainda em 2012, ao assistir a uma palestra sobre arquitetura da paisagem e espaços livres, que encontrei uma razão para chegar até esta dissertação.

Assim, agradeço a minha orientadora Luciana Schenk, que proferiu aquela palestra na FCTUNESP e que aceitou me orientar nesta jornada. Obrigado pela amizade, ensinamentos, sabedoria e experiências compartilhados. Seu amor e comprometimento em tudo o que faz são inspiradores.

Agradeço a Luciana por também ter me apresentado à ABAP [Associação Brasileira de Arquitetos Paisagistas]: do contato com os mestres e referências às visitas técnicas e eventos organizados, estar em rede é fundamental para a continuidade, valorização e disseminação da profissão.

Agradeço aos professores e às universidades públicas, em especial à USP e UNESP, que me possibilitaram ter acesso ao conhecimento e experiências que me tornaram a pessoa e profissional que sou.

Agradeço ao CNPq [Conselho Nacional de Desenvolvimento Científico e Tecnológico] e à CAPES [Coordenação de Aperfeiçoamento de Pessoal de Nível Superior] pelo auxílio financeiro que tornou possível esta pesquisa.

Ao Gabriel, agradeço pela paciência, pelo carinho e suporte; e por tornar tudo mais leve.

Aos amigos feitos no período do mestrado, agradeço pela amizade que se expande e permanece. Obrigado por todos os momentos.

Agradeço também às amizades estabelecidas nas cidades em que residi e paisagens que vivenciei por mais tempo: Catanduva, Presidente Prudente, São Carlos e, agora, Barretos. E aos laços e amigos que se estabeleceram a partir destas. Por todo o apoio, encontros, cafés e conversas. Cada um de vocês sabe o quanto é especial. Meu muito obrigado. 



\section{RESUMO}

FRANCISQUETI, Gabriel Valentini. Rios, cidade e espaços livres em Presidente Prudente - SP: a bacia hidrográfica do Córrego do Veado. Dissertação de mestrado. Instituto de Arquitetura e Urbanismo, Universidade de São Paulo. São Carlos, 2020.

As relações entre cidade e natureza e rios e cidade sofreram complexas alterações a partir das transformações provocadas pela rápida urbanização das sociedades a partir do advento da revolução industrial. Aquelas relações, antes harmônicas, transformaram-se em conflituosas. No Brasil, os conflitos presentes em nossas cidades refletem o modo de urbanização assim como as políticas de planejamento urbano adotadas, principalmente no decorrer do século XX, quando a população urbana supera a rural. Nos processos de construção da vida urbana, cidade e natureza foram colocadas uma contra a outra, intensificando as problemáticas entre o meio físico e os processos de ocupação - como inundações e alagamentos - e gerando alterações consideráveis na paisagem - como a invisibilização dos cursos d'água e de outros processos naturais -, que se torna monótona, e da qual a população passa a desconhecer a diversidade e possibilidades uma vez que a natureza é apresentada como um ente externo ao meio urbano. Com base nas metodologias e projetos desenvolvidos no campo disciplinar e profissional da arquitetura da paisagem, elege-se a bacia hidrográfica como unidade de planejamento e procura-se ressignificar as relações entre rios e cidade por meio de projetos - que vão desde os dispositivos da infraestrutura verde a um sistema de espaços livres que eduquem a população - educação pelo lugar e pelo olhar -, fazendo-a entender a participação e necessidade de manutenção dos processos ecológicos nas cidades para a manutenção da vida. Assim, este trabalho investiga as relações rio e cidade em Presidente Prudente - SP, uma cidade média brasileira e que, semelhante às grandes cidades - guardadas proporções e escalas - apresenta conflitos e problemáticas entre cidade e natureza decorrentes dos processos de planejamento e estruturação urbanos. Com o auxílio de documentos, fotos e bibliografias, faz-se uma descrição do surgimento e desenvolvimento da cidade à luz das políticas de planejamento e legislações - federal, estadual e municipal - e procura-se entender seu impacto sobre a paisagem da cidade e de seus fundos de vale, cursos d'água e áreas de preservação, refutando o senso comum de que "não houve planejamento para a cidade". Elegendo como recorte final para a pesquisa a Bacia Hidrográfica do Córrego do Veado, sobre a qual a cidade se expandiu e que se encontra completamente inserida na malha urbana de Presidente Prudente, o trabalho procura evidenciar possibilidades de projeto - desenvolvidas em um workshop com discentes do curso de arquitetura e urbanismo - a partir do planejamento sistêmico e ecossistêmico com a paisagem.

Palavras-chave: rios e cidade; paisagem; planejamento urbano; bacia hidrográfica; Presidente Prudente. 



\begin{abstract}
FRANCISQUETI, Gabriel Valentini. River, city and open spaces system in Presidente Prudente - SP: Veado's River basin. Master dissertation. Instituto de Arquitetura e Urbanismo, Universidade de São Paulo. São Carlos, 2020.

The relations between city and nature and rivers and city have undergone complex changes since the transformations that were caused by the rapid urbanization of societies since the advent of the industrial revolution. Those relations, which were once harmonious, became conflicted. In Brazil, the conflicts present in our cities reflect the mode of urbanization as well as the urban planning policies adopted, especially during the twentieth century, when the urban population surpasses the rural. In the processes of construction of urban life, city and nature were pitted against each other, intensifying the problems between the physical environment and the occupation processes - such as floods - and generating considerable changes in the landscape such as invisible streams and other natural processes -, which becomes monotonous, and from which the population is unaware of the diversity and possibilities since nature is presented as an entity external to the urban environment. Based on the methodologies and projects developed in the disciplinary and professional fields of landscape architecture, the hydrographic basin is chosen as a planning unit and seeks to reframe the relationship between rivers and the city through projects - ranging from green infrastructure devices to a system of open spaces system - which educate the population - education by place and by look -, making population understand the participation and the need to maintain ecological processes in cities in order to maintain life. Thus, this research investigates the relationship between river and city in Presidente Prudente - SP, a medium Brazilian city that, similar to large cities - kept proportions and scales - presents conflicts and problems between city and nature resulting from urban planning and structuring processes. Based on research in documents, photos and bibliographies, a description of the creation and development of the city was carried out in the light of the planning and legislation policies - federal, state and municipal - and seeks to understand its impact on the city landscape and its valley funds, rivers and streams and preservation areas, refuting the common sense that "there was no planning for the city". Choosing Veado's River Basin as the final delimitation for the research, over which the city has expanded and which is completely inserted in the urban area of Presidente Prudente, the work seeks to highlight project possibilities - developed in a workshop with students from architecture and urbanism graduation - having as a reference the systemic and ecosystem planning with the landscape.
\end{abstract}

Key words: rivers and city; landscape; urban planning; river basin; Presidente Prudente. 



\section{SUMÁRIO}

INTRODUÇÃO

1 CAPÍTULO I - RIOS E CIDADE E AÇÕES DE PLANEJAMENTO URBANO NO BRASIL

1.1 Relações rio-cidade 23

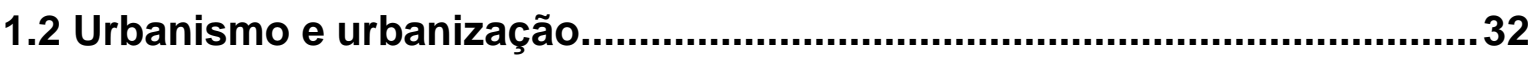

1.2.1 Urbanismo, urbanização e planejamento urbano no Brasil ........................ 34

1.3 Considerações sobre a cidade brasileira..................................................42

1.40 contexto de um planejamento regional para o estado de São Paulo e as cidades médias.

2 CAPÍTULO II - PLANEJAR COM A PAISAGEM .................................................55

2.1 Planejar com a paisagem - um percurso histórico....................................55

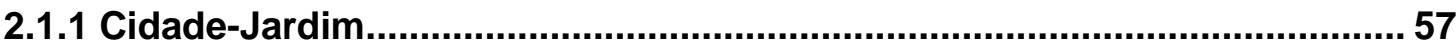

2.1.2 Espaços livres e planejamento com a paisagem: Frederick Law Olmsted 66

2.2 Paisagem e Arquitetura da Paisagem ....................................................70

2.3 Planejar com a paisagem: tempos recentes .............................................73

2.3.1 Planejamento a partir de uma unidade de paisagem: bacia hidrográfica.. 84

2.3.2 Infraestrutura verde. 95

3 CAPÍTULO III - PRESIDENTE PRUDENTE: HISTÓRIA, CRESCIMENTO E

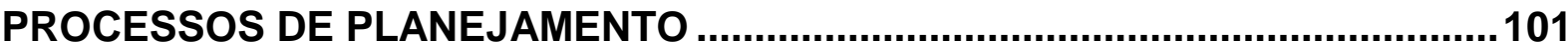

3.1 Histórico: surgimento e desenvolvimento até a década de 1950 ............104

3.2 Histórico: décadas de 1960 e 1970 - polo regional de desenvolvimento e primeiro plano diretor .........................................................................................114

3.2.1 CIBPU: Projeto de um Distrito Industrial (1966/1968) ................................. 115

3.2.2 CPEU: Plano Diretor de Presidente Prudente (1968/1969)....................... 124

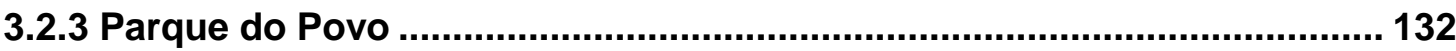

3.2.4 Programa CURA em Presidente Prudente ............................................. 136

3.3 Histórico: a expansão urbana a partir da década de 1980 .......................138 
3.4 Legislação municipal atual

3.4.1 Plano Diretor de Presidente Prudente - Lei no 230/2018............................ 147

3.4.2 Lei de Zoneamento do Uso e Ocupação do Solo - Lei no 231/2018 .......... 147

3.4.3 Lei de Parcelamento do Solo do Município - Lei no 232/2018 ................... 149

3.4.4 Lei do Sistema Viário - Lei no 233/2018 ................................................. 149

4 CAPÍTULO IV - PRESIDENTE PRUDENTE: BACIA HIDROGRÁFICA DO CÓRREGO DO VEADO ............................................................................. 153

4.1 Bacia Hidrográfica do Córrego do Veado: uma radiografia.................... 153

4.2 Relações rio - cidade e espaços livres: do passado à configuração atual 163

4.2.1 Surgimento do município até a década de 1950.......................................163

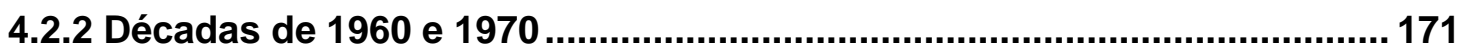

4.2.3 Décadas de 1980, 1990 e século XXI ........................................................ 186

5 CAPÍTULO V - WORKSHOP "PLANEJAR COM A PAISAGEM": UMA ALTERNATIVA PARA SE PENSAR O PLANEJAMENTO ................................. 201

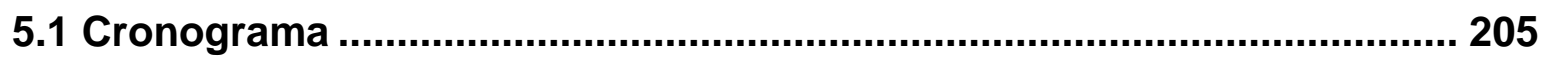

5.2 Percursos e experiências: estratégia metodológica ............................... 209

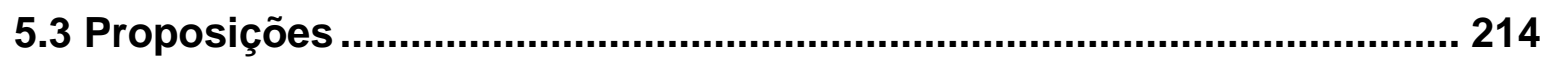

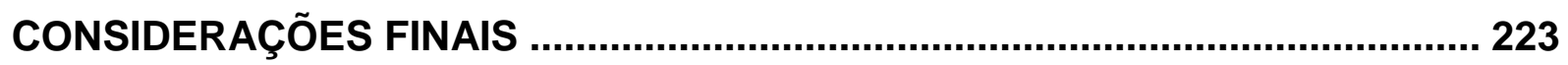

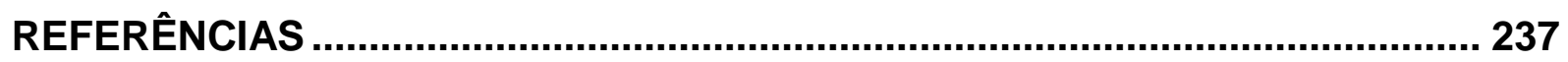

Todas as citações diretas em língua estrangeira presentes neste trabalho foram traduzidas pelo autor, com o trecho original indicado em nota de rodapé. 


\section{LISTA DE FIGURAS}

Figura 1- Os três ímãs, apresentando cada modo de vida e suas vantagens. 60

Figura 2 - Diagramas: distritos e centro da cidade-jardim; diagrama de crescimento; formação da rede de crescimento das cidades. .62

Figura 3 - Plano original de Letchworth Garden City, 1904. .63

Figura 4 - Ideia de um sistema: conexões entre os espaços livres - pequenos parques, grandes unidades de conservação, parques regionais. .66

Figura 5 - Corte Fisiográfico: estudo para a região do The Valleys..........................78

Figura 6 - Estudo de cenários possíveis para o projeto do The Valleys....................79

Figura 7 - Mapa síntese de aptidões. . .87

Figura 8 - Matriz elaborada por McHarg para a Bacia do Rio Potomac. .88

Figura 9 - À esquerda, meandros originais do Rio Don (Canadá), sobrepostos ao canal gerado pela urbanização da área. Á direita, a relação dos bairros do entorno com o acesso ao local.

Figura 10 - Plano estratégico para a parte baixa do Rio Don. .92

Figura 11 - Região administrativa de Presidente Prudente, com o município em destaque 101

Figura 12 - Unidades de Gerenciamento de Recursos Hídricos (UGRHI) do estado de São Paulo, com demarcação do município de Presidente Prudente (entre as unidades 21 e 22 do mapa). 102

Figura 13 - Recorte do mapa hipsométrico de Presidente Prudente, evidenciando as diferentes classes altimétricas dentro do perímetro urbano (contorno preto). 103 Figura 14 - Estado de São Paulo: cidades, inauguração das estações ferroviárias e expansão cafeeira. 105

Figura 15 - Excerto de jornal que traz detalhes sobre a venda das terras na região de Presidente Prudente. 106

Figura 16 - Planta da cidade de Presidente Prudente, 1923. 108

Figura 17 - Vila Goulart, a partir da estação, ainda sem a esplanada e praça da Bandeira (década de 1930). 110

Figura 18 - Vila Marcondes - Rua Quintino Bocaiúva, principal via comercial (década de 1940).

Figura 19 - Evolução Urbana de Presidente Prudente (1917 a 1967). 
Figura 20 - Vista parcial do centro de Presidente Prudente (1937), a partir do local da atual Santa Casa, na qual é possível observar que a cidade transpõe um dos primeiros fundos de vale. Neste caso, o do córrego Água Bôscoli..... 112 Figura 21 - Presidente Prudente, 1939. Representação elaborada pela Companhia

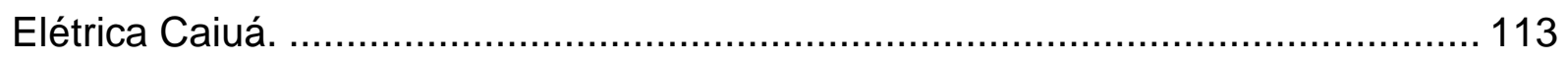
Figura 22 - Diretrizes de Organização Urbana para Presidente Prudente, com demarcação dos distritos/usos propostos. O fundo de vale do Córrego do Veado, em azul, aparece descrito na legenda como "faixa central".

Figura 23 - Distrito Industrial Diversificado, localizado a sudeste da mancha urbana, com destaque para os jardins/áreas verdes e caminhos exclusivos para pedestres.

Figura 24 - Distrito industrial proposto (à esquerda) e executado posteriormente (à direita). 122

Figura 25 - Ocupação do fundo de vale do Córrego do Veado (o córrego está representado pela linha pontilhada)............................................................. 123

Figura 26 - Trecho do Parque do Povo, Presidente Prudente. ............................ 123 Figura 27 - Hipótese de expansão urbana; os números representam as áreas que foram definidas como prioritárias.

Figura 28 - Malha urbana atual de Presidente Prudente, com demarcação da ferrovia (em vermelho) e do quadrilátero central, evidenciando o vetor de expansão a oeste da linha férrea. 128

Figura 29 - Plano de Massas e Sistema Viário existente e proposto. 129

Figura 30 - Plano de Massas: proteção dos fundos de vale e apontamento das unidades de ensino, existentes e propostas. 130

Figura 31 - Zoneamento proposto. 131

Figura 32 - Anteprojeto de Urbanização do Fundo de Vale do Córrego do Veado. 133 Figura 33 - Córrego do Veado retificado e canalizado em trecho do Parque do Povo.

Figura 34 - Desmoronamento das placas da canalização do Córrego do Veado, no Parque do Povo. 135

Figura 35 - Área do Parque do Povo em Presidente Prudente. 136

Figura 36 - Á esquerda, geomorfologia de Presidente Prudente: as áreas escuras representam as áreas de espigão. À direita, Córregos: do Veado (número 1), Água Bôscoli (2), Bacarin (3) e Salto (4,) sobre imagem atual. 
Figura 37 - Expansão da área urbana no período 1920 - 2015.

Figura 38 - Presidente Prudente em 1974, com demarcação do córrego do Veado (em azul).

Figura 39 - Presidente Prudente, 2019, com demarcação do córrego do Veado (em azul), da linha férrea (em vermelho) e do quadrilátero central (em amarelo). 143

Figura 40 - Expansão da malha urbana de Presidente Prudente-SP sobre o relevo (1917 - após 2000).

Figura 41 - Situação atual dos rios e córregos no perímetro urbano de Presidente Prudente, SP.

Figura 42 - Parâmetros e índices urbanísticos segundo a Lei de Zoneamento (Lei no231/2018) para Presidente Prudente-SP. 148

Figura 43 - Área da Bacia Hidrográfica do Córrego do Veado. 154

Figura 44 - Atual estado dos córregos que compõem a Bacia Hidrográfica do Córrego do Veado em Presidente Prudente-SP. 155

Figura 45 - Vista da cidade de Presidente Prudente, contendo os limites da Bacia Hidrográfica do Córrego do Veado, demarcação do núcleo central originário - em amarelo - e da altitude em diferentes pontos da bacia. Os três pontos em azul representam nascentes dos córregos atualmente invisíveis porque foram canalizados e tamponados na região central da cidade. 157

Figura 46 - Bacia Hidrográfica do Córrego do Veado. Os números indicam a localização dos pontos nos quais foram realizadas as fotografias. 159 Figura 47 - Compilado de fotografias que retratam as questões das enchentes, inundações e alagamentos em Presidente Prudente, na Bacia Hidrográfica do Córrego do Veado. 160

Figura 48 - Armazém e pátio da Estrada de Ferro Sorocabana, 1941. À direita, ao fundo, trecho da Vila Marcondes e Indústrias Matarazzo, que se instalariam na cidade em 1937. 164

Figura 49 - Espaços livres qualificados na década de 1940. 165

Figura 50 - Aerofoto Oblíqua de Presidente Prudente 1939/1940. 166

Figura 51 - Bosque Municipal, década de 1940. 167

Figura 52 - Planta de Presidente Prudente, 1947, com modificações feitas pelo autor. A imagem apresenta a indicação das nascentes dos córregos Bacarin e Água Bôscoli. 
Figura 53 - Detalhe ampliado da Planta de Presidente Prudente, 1947, com demarcação da região inicial do Córrego Água Bôscoli, já transformado em galeria.

Figura 54 - Bacarin: aterro do "buracão" e canalização do córrego, localizados em frente à "Casa Bacarin", sem data. .............................................................. 170 Figura 55 - Vista aérea (ao fundo) do loteamento Jardim Bongiovani, ainda desocupado. O Córrego do Veado com entorno desocupado, em partes, e em momento anterior às obras do Projeto Fundo de Vale, que originariam o Parque do Povo.

Figura 56 - Região do Córrego Água Bôscoli. 174

Figura 57 -Obras de canalização do Córrego Água Bôscoli, década de 1970. O local da foto corresponde à área ocupada atualmente pelo PUM. 175 Figura 58 - Antigo "Buracão do Bôscoli", onde está localizado o Córrego Água Bôscoli e sobre o qual foi construído o Parque de Uso Múltiplo (PUM), com recursos do programa CURA. 176

Figura 59 - Rua de Pedestres sobre o córrego Água Bôscoli, neste registro, canalizado e tamponado. 176

Figura 60 - Região do Córrego Bacarin 177

Figura 61- Tênis Clube de Presidente Prudente (sem data), À frente, avenida Washington Luiz e, ao fundo das quadras, o Córrego do Bacarin. 178 Figura 62 - Obras de canalização do Córrego Bacarin ..... 178

Figura 63 - Espaços livres percorridos no trecho intermediário do Córrego Bacarin, entre o Jardim Aviação e Jardim Paulista. 179 Figura 64 - Região do Córrego do Veado. 180 Figura 65 - Implementação do Parque do Povo no fundo de vale do Córrego do Veado. Na parte superior, pode-se observar a canalização aberta e o campo de futebol; na parte inferior, um canteiro de obras: terraplenagem, retificação do córrego e construção do canal. 181

Figura 66 - Parque do Povo, 2016: ao centro, cortando o parque, a Avenida da Saudade.

Figura 67 - Imagens do projeto "Fundo de Vale". 183

Figura 68 - Trecho de respiro do Córrego do Veado, no Parque do Povo, ao lado da Avenida da Saudade 184

Figura 69 - Trecho do Córrego Colònia Mineira. 185 
Figura 70 -Trecho do Córrego da UNESP.

Figura 71 - Região demarcando a área sobre a qual viria a ser construído o Prudenshopping, meados da década de 1970.

Figura 72 - Região de confluência dos córregos do Veado, Bacarin, Colônia Mineira e da UNESP, evidenciando a situação dos córregos na região. 188

Figura 73 - Rios, fundos de vale e espaços livres. 192

Figura 74 - Transição entre a canalização aberta e o trecho ainda não canalizado do Córrego do Veado. 193

Figura 75 - Região do Córrego Maracanã (à esquerda) e Córrego Colônia Mineira (à direita), em diferentes décadas. 194

Figura 76 - Região do Córrego do Saltinho, em diferentes décadas. 195 Figura 77 - Região do Córrego do Veado e Córrego da UNESP, em diferentes décadas

Figura 78 - Localização do Parque Ecológico em comparação com o Parque do Povo.

Figura 79 - Comparação entre o projeto e a implantação do Parque Ecológico. ...200 Figura 80- Palestra "O histórico do Planejamento com a Paisagem", por Luciana Schenk. 205

Figura 81 - Dinâmica-aula com as docentes Luciana Schenk e Arlete Francisco...206 Figura 82 - Cada grupo recebeu um mapa da cidade de Presidente Prudente com os trechos ou "fatias" (1 a 10) a serem palmilhadas de cumeada a cumeada, atravessando o vale. 207

Figura 83 - Apresentação dos campos realizados pelos grupos e dinâmica sobre o pensamento em totalidade para a Bacia a partir das cartografias produzidas 208 Figura 84 - Dinâmica de apresentação das propostas e intenções de projeto para a Bacia Hidrográfica do Córrego do Veado. 209

Figura 85 - Percurso planejado versus percurso sensível. 210

Figura 86 - Percursos e experiências. 211

Figura 87 - Percursos e experiências. 211

Figura 88 - Percursos e experiências. 212

Figura 89 - Percursos e experiências. 213

Figura 90 - Apresentação e discussão sobre as proposições para um projeto de paisagem pensando sistemicamente. 214

Figura 91 - Proposições elaboradas durante o workshop. 
Figura 92 - Proposições elaboradas durante o workshop.................................... 216

Figura 93 - Proposições elaboradas durante o workshop...................................... 217

Figura 94 - Proposições elaboradas durante o workshop..................................... 218

Figura 95 - Proposições elaboradas durante o workshop....................................... 218

Figura 96 - Proposições elaboradas durante o workshop...................................... 219

Figura 97 - Proposições elaboradas durante o workshop..................................... 220

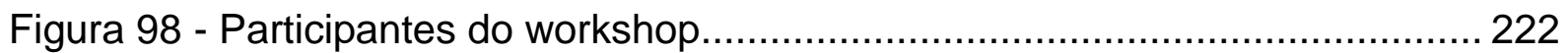




\section{INTRODUÇÃO}

No passado, a dependência do homem em relação a fontes próximas de água potável foi determinante para a escolha dos espaços que viriam a se constituir nas primeiras aglomerações humanas. Por apresentarem abundância em volume, permitindo além do consumo próprio o desenvolvimento da navegação e exploração de novas áreas, os rios foram utilizados como barreiras de segurança e também como de porta de entrada para a exploração de novas áreas, permitindo a conquista do território. Assim, grandes povoações foram estrategicamente estabelecidas de acordo com a proximidade a rios e outras fontes de água. Os rios eram vistos e entendidos como parte integrante da paisagem nestes locais.

Com o desenvolvimento de novas técnicas e domínio de novos processos e tecnologias, a água potável para abastecimento e consumo da população pôde vir de distâncias maiores e muitos dos rios e córregos foram se tornando as regiões de fundos das cidades. Com os processos de crescimento e explosão populacional urbanos, os rios passam a ser endereçados como locais nos quais eram despejadas as águas servidas e resíduos industriais. Grande parte das políticas de planejamento à época entenderam os rios como barreira e limite ao desenvolvimento das cidades, além de trazerem mau-cheiro, acúmulo de lixo e representarem regiões concentradoras de vetores de doenças.

A partir de então, os rios passam, pouco a pouco, a desaparecer no desenho de muitas cidades e, consequentemente, do imaginário da população. A relação harmônica e de necessidade mútua dá lugar a um processo de ruptura dos rios com as cidades (GORSKI, 2010) e sua invisibilização na paisagem (SPIRN, 1995). Transformados em canais e galerias fechadas, sobrepostos por ruas e avenidas e apresentando suas margens e área livres do entorno impermeabilizadas, os rios e fundos de vale tornam-se regiões de inundações e alagamentos frequentes sobre os quais são desenvolvidos novos projetos de drenagem que buscam solucionar matematicamente as problemáticas causadas pelo próprio processo de ocupação humana. É um ciclo no qual, cada vez mais, a cidade é entendida e vista como um ente separado da natureza, um produto humano que transforma o meio físico e natural e que, por isso, perderia sua relação com o todo.

O campo disciplinar do urbanismo e o da arquitetura da paisagem surgem para entender e repensar este modelo, buscando respostas para a má qualidade de 
vida e trabalho enfrentados pelos moradores das cidades industriais, que já se apresentavam insalubres no século XIX - no decorrer do trabalho será explicada a diferente abordagem e prosseguimentos dados por cada campo profissional e disciplinar. De todo modo, projetos e estudos teóricos, como os desenvolvidos por Frederick Law Olmsted (1822-1903), Ebenezer Howard (1850-1928) e Patrick Gueddes (1854-1932), propuseram alternativas para a precária situação da vida urbana entendendo a necessidade da participação dos processos naturais na construção das cidades ou buscando a reinserção dos mesmos nas já existentes, planejando com a paisagem através de um sistema de espaços livres, considerando a dinâmica dos processos naturais para, por exemplo, criar parques em diferentes escalas nas cidades.

No século XX, arquitetos paisagistas como lan McHarg (1920-2001), Michael Hough (1928-2013) e Anne Whiston Spirn (1947- ) pesquisariam e trabalhariam com a paisagem por meio de um planejamento ecológico e desenvolvendo metodologias de projeto que, cruzando informações, permitissem um trânsito de escalas (MCHARG, 1969), da local à regional, e evidenciando a importância de tornar visíveis os processos que sustentam a vida (HOUGH, 1998) para que a população entenda a necessidade de se considerar a cidade como parte integrante da natureza (SPIRN, 1995) para a manutenção da vida.

Em comum, esses autores abordam questões envolvendo os cursos d'água e sua importância para os processos de planejamento com a paisagem uma vez que representam, nos conflitos relacionados a processos de ocupação e o meio físico, grande parte da problemática atual das cidades ao mesmo tempo em que se apresentam como possibilidade de conexão dos diversos espaços e regiões em um planejamento sistêmico. As bacias hidrográficas emergem, então, como uma possível unidade de planejamento para a ressignificação dos rios e da natureza nas cidades.

No Brasil, o acelerado processo de urbanização e crescimento da população urbana foram responsáveis por intensificar o conflito entre cidade e natureza e agravar a relação entre rios e cidade. Muitas das políticas de planejamento urbano aplicadas eram frutos de um dos ramos do campo disciplinar que procurava a ordenação e saneamento das cidades, promovendo o desenvolvimento urbano sem considerar os processos naturais. Para o entendimento e discussão das problemáticas acima, esta pesquisa utiliza como referência os trabalhos produzidos por Milton Santos (19262001) e Flávio Villaça (1929-), entre outros; e, para entender como as questões de 
planejamento urbano e legislação reverberam além das metrópoles e grandes cidades, utiliza-se o repertório produzido pelas pesquisas de Maria Encarnação Beltrão Sposito (1955- ) sobre estruturação urbana e produção do espaço urbano nas cidades médias, chegando a Presidente Prudente-SP, cidade escolhida para esta pesquisa.

Assim, este trabalho apresenta como fio condutor a investigação histórica das relações rio e cidade para uma cidade média do interior paulista: Presidente Prudente, tendo como objetivo final a contextualização de um recorte, a bacia hidrográfica do Córrego do Veado, fazendo emergir possibilidades de um Sistema de Espaços Livres (SEL) a partir de um embasamento histórico dos processos de ocupação do território e das políticas de planejamento urbano e legislações aplicadas ao solo, cursos d'água e fundos de vale.

Para que o trabalho pudesse ser realizado, a metodologia desenvolvida contou com leitura e fichamento de artigos e livros que tratam das principais temáticas abordadas - urbanização e planejamento urbano no Brasil, cidades médias, paisagem e arquitetura da paisagem, espaços livres, rios e cidade - e também com a pesquisa histórica sobre a cidade de Presidente Prudente - buscando em livros, dissertações e teses os processos de formação do município e seu desenvolvimento urbano.

Além disso, foi realizada uma pesquisa documental, que buscou por cartografias, mapas e imagens históricas no Museu Histórico Municipal de Presidente Prudente, no Arquivo Público do Estado de São Paulo e nas bibliotecas da Faculdade de Ciências e Tecnologia da UNESP em Presidente Prudente-SP (FCT-UNESP) e da Faculdade de Arquitetura e Urbanismo da USP (FAU-USP) em São Paulo-SP. As fotografias com fonte "arquivo do autor" são resultado dos trabalhos de campo realizados durante os anos de graduação e também no decorrer dos anos de mestrado; as imagens e fotografias sobre o workshop são, em sua maioria, produto dos trabalhos desenvolvidos pelos discentes do terceiro ano - 2019 - do curso de arquitetura e urbanismo da FCT-UNESP, a partir de uma oficina que percorreu o território da bacia hidrográfica do Córrego do Veado em Presidente Prudente, e foi realizada por meio de uma parceria entre as docentes Prof. ${ }^{-}$Dr. ․ Luciana Bongiovanni Martins Schenk (IAU-USP) e Prof. ${ }^{\text {a }}$ Dr. ${ }^{\underline{a}}$ Arlete Maria Francisco (FCT-UNESP).

Deste modo, a dissertação apresenta-se dividida em cinco capítulos: I- "Rios e cidade e ações de planejamento urbano no Brasil"; II- "Planejar com a paisagem"; III- "Presidente Prudente - história, crescimento e processos de planejamento"; IV- 
"Presidente Prudente: Bacia do Córrego do Veado"; e V- "Workshop Planejar com a paisagem: uma alternativa para se pensar o planejamento". A estrutura do trabalho foi dividida em uma abordagem de temas e processos ocorridos a nível global - neste caso, tendo o ocidente como referência - e nacional - capítulos I e II - e depois, a nível local - capítulos III, IV e V.

Assim, o primeiro capítulo trata das questões rios e cidade e dos processos de planejamento urbano brasileiros, abordando desde o surgimento do campo disciplinar do urbanismo à urbanização em cidades brasileiras, chegando ao nível das cidades médias.

O segundo capítulo traz a temática de planejamento com a paisagem, discutindo que, ao passo que a urbanização e o planejamento urbano "convencionais" contribuíam para a ruptura das relações rios e cidade, outras correntes de pensamento e projetos mostram uma outra abordagem, que planeja com e a partir da natureza e seus processos, evidenciando possibilidades concretas - de metodologias a projetos executados - de ressignificar as relações rios, cidade e espaços livres a partir de uma unidade de planejamento: a bacia hidrográfica.

Relacionado ao primeiro capítulo, mas trazendo a abordagem para o nível local, da cidade de Presidente Prudente, o terceiro capítulo trata do histórico do surgimento da cidade, seu desenvolvimento sobre o relevo e meio natural, sua elevação a capital e polo regionais, políticas de planejamento urbano e ressonâncias locais e, por fim, a influência das legislações na ocupação do território. O terceiro capítulo aborda então as questões que caracterizam a cidade e sua forma urbana.

O quarto capítulo faz uma radiografia da bacia hidrográfica do Córrego do Veado em Presidente Prudente-SP - que se encontra completamente ocupada pela malha urbana - contextualizando sua ocupação e processos de planejamento através de imagens comparativas entre diferentes décadas. Procura evidenciar a ocupação dos fundos de vale dos rios e córregos na referida bacia hidrográfica, apontando também para a formação e definição de seus espaços livres.

No quinto capítulo, o "Workshop Planejar com a paisagem: uma alternativa para se pensar o planejamento" encerra o trabalho, descrevendo metodologias e possibilidades - como as discutidas no segundo capítulo - para as problemáticas e conflitos encontrados em uma cidade e sua principal bacia hidrográfica - nas quais ecoam ressonâncias do fenômeno da urbanização e dos processos de planejamento urbano discutidos no primeiro capítulo. 


\section{CAPÍTULO I - RIOS E CIDADE E AÇÕES DE PLANEJAMENTO URBANO NO BRASIL}

A água é o sangue da vida das cidades: impele as fábricas, aquece e resfria as casas, nutre os alimentos, mata a sede e carrega os dejetos. As cidades importam mais água do que todos os outros bens e matérias-primas combinados. Água suficiente não é apenas um prérequisito para a saúde, é essencial para a vida". (SPIRN, 1995, p.145)

\subsection{Relações rio-cidade}

Desde os primórdios das civilizações, a questão da água sempre foi de suma importância, seja para consumo, para locomoção e transporte, conquista territorial, segurança e poder. Historicamente sociedades foram fundadas próximas às águas e assim também é que se mantém diversas cidades pelo mundo. Do mesmo modo em relação às águas, conquistar os mares e dominar a navegação representava o poder de civilizações sobre as outras.

No Brasil, mesmo as cidades litorâneas surgiram a partir da instalação dos povoados próximos a fontes de água doce, como rios e lagoas. Os rios representaram uma porta de entrada para a conquista do território quando este era ainda predominantemente povoado pelos índios e dominado por uma vegetação densa e de difícil permeabilidade. Boa parte do interior do Brasil - e da América enquanto continente - foi desbravado e ocupado a partir da grande rede de rios que corta o território, muitos deles se dirigindo "continente adentro".

Ao longo dos tempos, porém, essa relação harmônica e de dependência entre a sociedade e o rio foi se alterando, e "a evolução da urbanização foi conseguindo eclipsá-los e anular sua importância, restringindo sua presença quase apenas aos sintomas perturbadores, ou seja: mau cheiro, obstáculo à circulação e ameaça de inundações" (GORSKI, 2010, p. 31); a relação entre natureza e cidade, que era harmônica, passa então a ser uma relação de conflito. Ainda de acordo com a autora, o período em que essa relação passa a ser conflituosa se dá, no Brasil, por volta da metade do século $X X$, acentuando-se após o processo de industrialização, em especial a partir do final dos anos 1960 , quando a população urbana no país supera a rural - os dados seriam revelados pelo Censo 1970.

Neste momento de intensa urbanização e aglomeração da população, com incipientes políticas de planejamento e fixação da população, aumenta a ocupação 
dos fundos de vale, a ampliação e espraiamento das periferias das cidades, registrase o saneamento básico insuficiente, que somados aos processos industriais, geram poluição e mau-cheiro. Esse processo contribui na percepção de que os rios e córregos serão mal vistos e "dispensáveis" por parte da população, sendo sua canalização vista como uma ação necessária, contudo, em relação às populações mais vulneráveis, a realidade é ainda pior:

O difícil acesso da população de baixa renda às áreas mais centrais das cidades contribuiu, segundo Rolnik ${ }^{1}$ (1997), para a expansão da periferia, o que muitas vezes implicou, e implica ainda, invasão de áreas de proteção de mananciais, com a aquiescência do poder público. Essa dinâmica agravou a situação de risco dos mananciais, pela eliminação das matas ciliares e consequente erosão das margens dos cursos d'água e assoreamento de suas calhas, e pela contribuição do esgoto in natura. (GORSKI, 2010, p. 62)

Gorski (2010) ainda cita a cultura do automóvel e a difusão do modelo rodoviarista como grandes responsáveis pelos casos de transformação dos fundos de vale em corredores viários, muitos deles em obras que aterraram e tamponaram os córregos, provocando sua invisibilidade (SPIRN, 1995); a partir da década de 1970 e nos anos 1980, a grande maioria das cidades brasileiras de médio e grande porte transformou muitos de seus fundos de vale em vias de trânsito rápido, inspiradas na retificação do rio Tietê em São Paulo e na construção de suas vias marginais.

Excetuando-se os maiores, todos os córregos e cursos d'água da paisagem anterior à urbanização desapareceram dos mapas modernos. Cobertos e esquecidos, antigos cursos d'água ainda correm através da cidade, enterrados sob o solo em grandes tubulações, canais primários de um sistema de drenagem subterrâneo. Seu ruído abafado pode ser ouvido sob as ruas após uma chuva pesada; eles são invisíveis, mas sua contribuição potencial às enchentes a jusante não é, todavia, diminuída, mas sim, aumentada. (SPIRN, 1995, p. 146)

Situação comum ao se lidar com os rios urbanos, a cena acima se repete nas cidades brasileiras; Gorski também enfatiza a alteração da paisagem urbana ao se canalizar córregos e embuti-los em dutos e galerias, "contribuindo para a descaracterização dos vales e para a ocorrência de inundações" (GORSKI, 2010, p 42).

${ }^{1}$ ROLNIK, Raquel. A cidade e a lei: legislação, política urbana e território na cidade de são Paulo. São Paulo: Studio Nobel. 1997 
Com as inovações e soluções técnicas ao longo do século $X X$, em grande parte pensadas para as questões de drenagem - levar a água das chuvas até os rios e destes para fora da área urbana no menor tempo possível - os córregos e rios deixam de ser parte da paisagem urbana e cada vez mais perdem seu contexto no imaginário da sociedade, que não mais precisa buscar água diretamente nos córregos, e nem precisa mais utilizá-los para navegação ou orientação, uma vez que as estradas, e não mais os cursos de água, conectam os lugares e pessoas. A poluição e mau-cheiro contribuem para esse afastamento e, então, as obras de canalização e tamponamento ou de construção de vias marginais, vem para ratificar a ruptura (GORSKI, 2010) dos rios com a cidade.

Ao verificarem-se as situações de ruptura nas relações entre as cidades e os cursos d'água ou, mais amplamente, entre sociedade e natureza, percebe-se nitidamente que o desligamento físico do rio das funções urbanas acarreta num desligamento afetivo dos sistemas fluviais e fundos de vale, e a eles se atribuem características de entrave e de elemento de depreciação do ambiente urbano. (GORSKI, 2010, p. 68)

Observa-se que o processo de ordenamento e crescimento das cidades não apenas criou um conflito entre cidade e natureza, mas também o agravou. O planejamento territorial, que muitas vezes ignorou o relevo, ignorou também as áreas de várzea e fundos de vale, que à época das chuvas é ocupada pelas águas fluviais, em um movimento de cheias que é natural.

Enchentes são processos naturais do ciclo hidrológico, mas inundações resultantes de urbanização são processos combinados de ocupação do solo, a começar pelas planícies de várzea, que originalmente eram reservatórios naturais de absorção. (GORSKI, 2010, p. 66)

Trata-se da natureza ocupando um lugar que sempre foi seu; mas aos olhos da população, que enxerga o rio como criador de conflito e entrave à vida urbana, e não como potencial criador de vida: a natureza mais uma vez é vista como culpada por um processo que foi, muitas vezes, fruto de um planejamento feito pelo homem.

Com uma visão mais técnica a respeito das águas urbanas, que envolvem não somente os rios e córregos, mas os sistemas de abastecimento, saneamento e drenagem, bem como seus processos, Tucci (2008) apresenta em seu trabalho o impacto sobre águas urbanas a partir do planejamento urbano para a cidade formal e também sobre a ocupação do território e a produção da cidade informal. 
Os principais problemas, segundo o autor, estão relacionados à deterioração da qualidade da água por falta de tratamento de esgoto, a ocupação das áreas de várzea e sua impermeabilização, provocando inundações, bem como a canalização e retificação dos rios urbanos, que provocam impermeabilização do leito, diminuição da absorção e aumentam a velocidade e vazão das águas, acarretando problemas e incidentes em outros pontos.

Outra questão importante trazida pelo autor, e que nos auxilia na compreensão acerca da relação rio-cidade, é uma periodização do desenvolvimento histórico sobre as águas urbanas em quatro fases: pré-higienista, higienista, corretiva e desenvolvimento sustentável (TUCCI, 2008).

A primeira, pré-higienista, ocorre até o início do século $X X$ e apresenta como características o esgoto em fossas ou na drenagem sem coleta e tratamento e a água proveniente de fontes, poços e rios; como consequências, doenças e epidemias. A segunda fase, higienista, que se prolonga até a década de 1970, é marcada pelo transporte de esgoto para áreas distantes das pessoas, tendo como consequências a canalização do escoamento, rios contaminados, impactos na água e inundações. Entre 1970 e 1990, a terceira fase, corretiva, apresenta um início do amortecimento do escoamento e de tratamento do esgoto, com a recuperação de rios, obras hidráulicas e impacto ambiental. A partir de 1990, período marcado pelas mudanças de postura relacionadas ao chamado desenvolvimento sustentável, entra em pauta a conservação ambiental, redução das inundações e melhoria da qualidade de vida, apresentando esta fase a característica de novos processos que preservam o sistema natural.

O autor pontua que o Brasil ainda se encontra na fase higienista - reiterando que deve-se analisar as especificidades de cada local - evidenciando que o tratamento dado aos rios urbanos no país relaciona-os a canais de transporte de esgoto e drenagem rápida das águas pluviais, contribuindo para inundações e que permanecem ratificando um processo de planejamento de canalização e retificação cumpre mencionar que atualmente só não é concluído com o tamponamento porque a legislação ambiental não mais o permite - excetuando-se casos específicos.

Com relação a uma legislação brasileira de proteção aos rios e suas margens, apenas na década de 1960 do século XX, com o Código Florestal - Lei o 4771 de 1965 - é que se teve a definição de uma Área de Preservação Permanente (APP) 
(BRASIL, 1965); em sua redação original, no artigo 1ำ § $2^{\circ}$, inciso II, o Código Florestal de 1965 definia:

área de preservação permanente: área protegida nos termos dos artigos $2^{\circ}$ e $3^{\circ}$ desta lei, coberta ou não por vegetação nativa, com a função ambiental de preservar os recursos hídricos, a paisagem, a estabilidade geológica, a biodiversidade, o fluxo gênico de fauna e flora, proteger o solo e assegurar o bem estar das populações humanas; (BRASIL, 1965)

A lei que instituiu o Código Florestal previa também uma faixa de cinco metros de proteção às matas ciliares, para cursos d'água de até dez metros de largura; como não havia legislação federal relacionada à proteção das margens e rios em áreas urbanas, e como não havia uma legislação federal sobre parcelamento do solo, aplicava-se também ao urbano o que era previsto no Código Florestal (BRITO et al., 2012).

Apenas em 1979, com a publicação da Lei n 6766, ou Lei Lehmann, que dispõe sobre o parcelamento do solo urbano, é que passou a vigorar a especificação de uma faixa non aedificandi de quinze metros para cada lado dos rios e córregos, entre outros. O artigo $4^{\circ}$ da Lei $n^{\circ}$ 6766/79 exige, entre os requisitos mínimos, que:

ao longo das águas correntes e dormentes e das faixas de domínio público das rodovias, ferrovias e dutos, será obrigatória a reserva de uma faixa "non aedificandi" de 15 (quinze) metros de cada lado, sem exigência de área verde, salvo maiores exigências da legislação específica. (BRASIL, 1979)

Em 1986, com a Lei no 7511, a distância mínima passou a ser de 3ํmetros a partir do leito regular; com a Lei n 7803 , de 1989, os limites passaram a ser medidos a partir do leito maior, considerando o período de cheias.

A legislação que dispõe atualmente sobre o tema é o Código Florestal, Lei no 12651 de 2012 - com alterações incluídas pela Lei no 12727 de 2012 - que define no artigo 4을

Considera-se Área de Preservação Permanente, em zonas rurais ou urbanas, para os efeitos desta Lei:

I - as faixas marginais de qualquer curso d'água natural perene e intermitente, excluídos os efêmeros, desde a borda da calha do leito regular, em largura mínima de: (Incluído pela Lei no 12.727, de 2012). a) 30 (trinta) metros, para os cursos d'água de menos de 10 (dez) metros de largura;

b) 50 (cinquenta) metros, para os cursos d'água que tenham de 10 (dez) a 50 (cinquenta) metros de largura;

c) 100 (cem) metros, para os cursos d'água que tenham de 50 (cinquenta) a 200 (duzentos) metros de largura; 
d) 200 (duzentos) metros, para os cursos d'água que tenham de 200 (duzentos) a 600 (seiscentos) metros de largura;

e) 500 (quinhentos) metros, para os cursos d'água que tenham largura superior a 600 (seiscentos) metros. (BRASIL, 2012).

Desde a publicação do Código Florestal, em sua versão de 1965 até a mais recente, em 2012, e somadas outras leis, como a Lei Lehmann, e resoluções, as áreas de preservações passaram de $5 \mathrm{~m}$ iniciais a uma faixa non aedificandi de trinta metros em cada margem - para cursos d'água com menos de 10 metros, que são cursos de água que interessam a esse trabalho em específico. Houve ganho de áreas permeáveis e proteção a matas ciliares e ao ecossistema como um todo, institucionalizou-se o espaço livre lindeiro a essas áreas e mais, com a lei de parcelamento do solo urbano, os espaços livres públicos urbanos foram federalmente institucionalizados: na lei original do parcelamento do solo, foram fixadas as porcentagens de doação de áreas públicas: $20 \%$ de sistema viário, $5 \%$ de área institucional e 10\% de área verde/sistema de lazer. Com a revisão feita em 1999, a definição dessas porcentagens passou a ser atribuição de cada município.

Porém, não se pode deixar de mencionar que muitas cidades brasileiras tiveram sua fundação em datas anteriores às legislações, além da efetividade na aplicação das mesmas ter passado por um conflituoso processo, no qual grande parte das áreas de proteção, fossem elas de cinco ou trinta metros, já estavam ocupadas pela população há anos. Assim, em todo o país, fossem as cidades metrópoles, grandes, médias ou pequenas, o conflito rio-cidade estava não só instaurado como em franco crescimento.

A cidade de São Paulo é um grande exemplo dos processos relatados anteriormente, que exemplificam o desenvolvimento das diferentes fases das águas urbanas e que serviu como paradigma para projetos e processos de planejamento e ocupação de fundos de vale e áreas ribeirinhas em muitas outras cidades do país, e no interior do próprio estado, como veremos em Presidente Prudente.

Assim como existem diferentes classificações para a evolução urbana das "muitas São Paulos", conforme descreve Campos (2002) ao citar os diferentes trabalhos e autores ${ }^{2}$ que pesquisaram o processo de surgimento e desenvolvimento

2 São eles: Benedito Lima Toledo aborda três momentos na evolução de São Paulo: a cidade colonial, a metrópole do café e a cidade atual. Nestor Goulart Reis apresenta quatro fisionomias para a cidade: a cidade de taipa (até 1888), a cidade europeia (1889 a 1930), a cidade modernista (1930 a 1960) e a metrópole centralizada. Prestes Maia organiza as alterações na estrutura urbana da cidade de acordo 
dessa cidade, também se pode periodizar e caracterizar a evolução das relações entre a cidade de São Paulo e seus rios.

Em A fluvialidade em rios paulistas, Oseki e Estevam (2006) apresentam um histórico da ocupação e das intervenções em fundo de vale na cidade de São Paulo, em que se propuseram a "descrever o processo de perda gradativa da relação entre a cidade e seus rios, rios estes que foram responsáveis pela sua própria condição de metrópole brasileira" (OSEKI; ESTEVAM, 2006, p. 90), permitindo-nos ratificar o que é apresentado por Tucci (2008) e comparar, em diferentes escalas e perspectivas, o que se vê em todo o país quando o assunto aborda as águas urbanas, especialmente na relação entre a cidade e seus rios e córregos.

Fundada no século XVI, ainda como vila de São Paulo de Piratininga, em uma colina entre os rios Anhangabaú e Tamanduateí, São Paulo funciona como local entreposto de mercadorias entre o interior e o porto de Santos até meados do século XIX, quando a produção de café no estado passa a transformar a cidade, que se desenvolveria ainda mais rápido com a instalação da rede ferroviária conectando diferentes produtores do interior até o porto de Santos, atravessando a cidade e tornando-a entroncamento da rede, com as estações da Luz (São Paulo Railway), Sorocabana e estação Norte (Central do Brasil), todas instaladas nas planícies próximas aos grandes rios que por muitos anos funcionaram como um limite para a cidade, Tietê e Tamanduateí. Ainda no século XIX, a cidade já sofria com as consequências de inundações e com o desafio de lidar com as águas servidas:

As grandes cheias ocorridas durante o século XIX, bem como o déficit na coleta de esgotos (presente até hoje) foram causadores de diversas epidemias, sendo que a maior delas se deu em 1855, quando a cidade sofreu um grave surto de cólera (OSEKI, ESTEVAM, 2006, p. 85).

Entre os anos de 1874 e 1920, São Paulo passa por um período de explosão demográfica, com sua população crescendo dos 20 mil habitantes para cerca de 580 mil; como relatam Oseki e Estevam (2006). Com a construção das ferrovias e o início do processo industrial, que se fortalece com a crise de 1929, os fundos de vale começam a ser ocupados pelos trilhos, pelas fábricas, pelas vilas operárias, esse processo se materializa numa cidade que passa a ser composta por retalhos de

com quatro administrações municipais: João Teodoro (1872-1875), Antônio Prado (1899-1910), Raimundo Duprat (1911-1914) e sua própria administração, no período (1938-1945). Disponível em: Campos, Cândido Malta. Os rumos da cidade: urbanismo e modernização em São Paulo, São Paulo: Editora Senac São Paulo, 2002. 
diferentes loteamentos das antigas chácaras que ficavam nos arredores do triângulo histórico da cidade.

O resultado dessa ocupação dos fundos de vale e do crescimento exponencial da população é a primeira etapa de intervenções nos cursos d'água da cidade, em uma tentativa de controlar as inundações ocasionadas pela ocupação das várzeas, e melhorar as condições de saneamento. Trata-se da primeira fase (OSEKI; ESTEVAM, 2006), que ocorreu, segundo os autores, entre meados do Século XIX e a década de 1920, na qual foram retificados trechos do rio Tamanduateí e do rio Tietê.

A segunda etapa, conhecida como "fase das canalizações e das avenidas de fundo de vale" foi proposta nos planos e processos de planejamento para a cidade: 0 Plano de Avenidas, de Prestes Maia, o Plano Moses (1950) e Sagmacs (1957) e, ao fim, a consolidação do modelo no Plano Urbanístico Básico (1968) que "recomendava o uso dos vales como suporte das avenidas, em função do baixo custo e da topografia suave. As várzeas deixariam de ser os fundos da cidade [...]" (OSEKI; ESTEVAM, 2006, p. 85). Na década de 1970 foram construídas as marginais dos rios Tietê, Pinheiros e a avenida do Estado no rio Tamanduateí, todas realizadas após a retificação dos mesmos rios. Com isso:

\begin{abstract}
A conjugação de canais e vias marginais tornou-se a prática urbanística recorrente para ocupação das várzeas na cidade de São Paulo. O binômio saneamento/vias públicas enraizou-se na administração municipal e metropolitana como maneira eficiente do poder público resolver vários problemas simultaneamente. (OSEKI; ESTEVAM, 2006, p.85).
\end{abstract}

A terceira fase, chamada por Oseki e Estevam (2006) de "reservação" foi uma resposta para tentar corrigir ou diminuir os impactos causados pela fase anterior. Porém, ao impermeabilizar grandes áreas das várzeas e carregar mais rapidamente o volume de águas para a jusante foi responsável por aumentar a frequência das enchentes e inundações. Esta terceira fase é caracterizada pelos "reservatórios de amortecimento", ou simplesmente, piscinões, que funcionam armazenando a água em pontos estratégicos, ajudando a controlar o volume de água que chega à jusante. $\mathrm{O}$ primeiro piscinão foi inaugurado em 1992, no Pacaembu, sob a praça Charles Miller e, atualmente, a cidade de São Paulo conta com 32 piscinões construídos, segundo o DAAE (Departamento de Águas e Energia Elétrica do Estado de São Paulo).

A partir do que foi abordado e descrito, conclui-se que o crescimento e o ordenamento da cidade são parte de um processo que, muitas vezes, termina por 
construir o conflito entre rio e cidade. E que o modo como são tratados os rios em seus trechos urbanos são parte de um modelo de planejamento urbano que num primeiro momento histórico, tem seus canais como escoamento de águas servidas, e depois como canais de drenagem, modelo que culmina finalmente com suas várzeas transformadas em pistas de rolamento para o tráfego.

Neste processo, muitos dos córregos e rios foram ainda eclipsados, tamponados, ocultos da paisagem, invisibilizados (SPIRN, 1995) e tornadas meras galerias subterrâneas, que recuperam sua força e caráter ao início das chuvas mais intensas causando inundações; o processo de tamponamento de rios e córregos cessou apenas porque os órgãos legislativos ambientais atuam para impedir essa agressão ambiental. Porém, a canalização e retificação, que impermeabilizam as margens e ampliam a velocidade das águas, ainda são permitidas.

O modelo de planejamento e gestão das águas adotado contribuiu não só para aumentar justamente os mesmos problemas de drenagem - inundações -, como também contribuiu para afastar cada vez mais a população do contato com os rios urbanos e o espaço livre por eles representados.

Porém, ao mesmo tempo em que se replicavam obras de canalização e tamponamento de córregos, políticas de construção de marginais, ocupação de fundos de vale, impermeabilização das várzeas e construção de piscinões, alguns grupos já estudavam e aplicavam outros modos de projetar com a paisagem, mantendo o meio ambiente natural e suas águas como protagonista de um sistema de espaços livres. As questões de planejamento e projeto com a paisagem serão abordadas em tópico mais à frente.

O que se pode dizer, apresentando o fio que conduz esse trabalho, é que o primeiro passo para que essa relação conflituosa se transforme é que é necessário "habitar o rio" (COSTA, 2006, p. 11), torná-lo visível ao imaginário e memória da população, para que ela o reconheça como paisagem. Na descrição de Costa (2006), que indaga como as cidades habitam os rios:

[Habitar] É quando a intervenção humana, no seu processo de construção, e portanto de transformação de mundo, revela e valoriza ainda mais os significados e os atributos da paisagem, tornando-os visíveis. Por este enfoque, muito de nossos rios ainda estão por ser habitados. [...]

Reconhecer o rio como paisagem, portanto, é habitar o rio. (COSTA, 2006, p. 10 e p. 11) 


\subsection{Urbanismo e Urbanização}

As questões que envolvem o conflito entre natureza e cidade, ou entre rios e cidade em particular, têm seu surgimento e potencial compreensão a partir das lógicas de ocupação do território e como foram ordenadas as nossas aglomerações urbanas, desde seu processo de surgimento e criação bem como sua transformação ao longo dos tempos, envolvendo diferentes atores, políticas, legislações e entes de planejamento. Assim, este trecho do trabalho levanta questões e conta um pouco do histórico do processo de urbanização e planejamento urbano no Brasil.

O surgimento do urbanismo como campo de conhecimento e estudo, no sentido de se realizar análises e pesquisas com intuito científico para proposição de ideias deu-se a partir da instauração de uma nova realidade advinda com a Revolução Industrial: a sociedade capitalista moderna e a cidade industrial. Como relata MonteMór (2008, p.33), "diversas correntes se formaram sob diferentes enfoques, mas sempre partindo do princípio de que a industrialização gerou uma desordem social e urbana, à qual deveria ser imposta, ou aposta, uma nova ordenação espacial".

De fato, o avanço da era industrial - baseada na exploração do carvão, desenvolvimento do vapor, maquinaria, grandes fábricas, linhas férreas, escoamento de produção, busca por matérias primas - levou a uma transformação do mundo e expansão sem precedentes das cidades, que explodiram em população. $\mathrm{O}$ avanço, porém, nem sempre foi acompanhado por uma estruturação e planejamento, e então as cidades tornavam-se insalubres e pouco atrativas: havia falta de saneamento, poluição, precariedade nas habitações, nos espaços públicos, na vida social, além da insalubridade nas condições de trabalho: era, portanto, uma cidade miserável (GEDDES, 1915).

No século XIX a Revolução Industrial deixou outras profundas e bem conhecidas marcas nas cidades europeias: pelo inédito aumento de suas populações, da poluição do ar e dos cursos d'água, de grandes problemas de higiene e consequentemente da enorme deterioração do ambiente urbano. É na habitação dos operários e da massa dos sem-trabalho que se vê obrigada a deixar o campo e as cidades de pequeno porte para procurar melhor sorte, que os resultados são contundentes. [...] Com frequência, as habitações operárias situavamse em vielas estreitas, sem contar com iluminação e ventilação razoáveis. (OTTONI, 1996, p.18)

Por pressão da população e reflexões elaboradas por pensadores e teóricos frente às condições de vida insalubres, em 1848 o Parlamento inglês aprova a Public 
Health Act, primeira de uma série de leis que visava à ordenação das cidades, regulando a construção de edificações e das ruas. Junto a esta lei, outras complementares viriam (1851, 1858 e 1875), regulando até mesmo o espaço entre as edificações; a partir delas, uma série de obras de melhoramentos e obras de saneamento foram realizadas em Londres. O mesmo ocorre em Paris, que tem na reforma proposta por Napoleão III e liderada por Georges Eugène Haussmann, entre 1853 e 1870, o exemplo mais influente das reformas das cidades industriais do Século XIX, com novos eixos de circulação, melhorias em saneamento, espaços de lazer e cultura, praças, bulevares, novos prédios públicos e espaços livres visando à salubridade urbana e social.

Era o início de uma nova realidade: a ideia de planejar o urbano disseminaria teorias e técnicas mundo afora, tal qual ocorreu com a própria expansão do capital industrial e das indústrias - e as mazelas geradas por esse modelo. Esses acontecimentos fariam surgir, no início do século $\mathrm{XX}$, uma disciplina que englobaria 0 estudo e análise dessa (r)evolução ${ }^{3}$ urbana: o urbanismo.

Tomemos apenas, como ponto de partida, a emergência de saberes sobre a cidade como objeto global, como organismo, [...], como sistema. Entre os precursores, Cerdà, cuja Teoria geral da urbanização foi publicada em 1867. Mas o momento decisivo é posterior: são os anos 1900-1910 quando aparecem simultaneamente na Grã-Bretanha o "city survey" e o "town planning", na França, a "ciência das cidades" e o "urbanismo", nos Estados Unidos, o "city planning", que precede em mais de uma década a "human ecology". O que marca desde a origem estas disciplinas é a procura de uma ordem escondida sob a desordem aparente, ao mesmo tempo que a definição de meios para remediar esta desordem. (TOPALOV; LEME, 1991, p.29)

Como relata Choay (1970), têm-se então o nascimento do campo teórico - o urbanismo - que abordará os processos - a urbanização - seus fenômenos e problemáticas, a partir de um campo disciplinar que, como mencionado acima,

\footnotetext{
${ }^{3}$ O termo revolução urbana faz referência ao livro A Revolução Urbana, publicado em 1970 por Henri Lefébvre. Na obra, o autor faz uma análise do fenômeno urbano a partir da transformação da sociedade, que passa por três fases: rural, industrial e, em um período pós-industrial, tornando-se uma sociedade urbana. Em sua análise, Lefébvre critica ainda o próprio urbanismo (no caso, o urbanismo moderno), por considerá-lo enquanto campo de conhecimento um urbanismo de classe, ao não considerar a transformação nas relações sociais. O urbanismo moderno seria tecnocrata e acabaria por promover, em resumo, o zoneamento monofuncional, resultando em uma sociedade dividida, por funções e atividades, de acordo com um "capitalismo organizacional", que acabaria por reforçar o modelo de desenvolvimento centro-periferia.
} 
procurará a ordem em meio à desordem (TOPALOV; LEME, 1991) advinda com as novas realidades apresentadas pelas cidades a partir da industrialização.

\subsubsection{Urbanismo, urbanização e planejamento urbano no Brasil}

Durante muito tempo, do início da ocupação portuguesa no território e por mais de duzentos anos seguintes, o Brasil apresentou-se como um país essencialmente agrícola e rural. Nesse período, a cidade se manifesta mais como "uma vontade de marcar presença num país distante" (SANTOS, 2005, p. 19). Fato que só começaria a se alterar a partir do século XVIII, quando "a casa da cidade tornase a residência mais importante do fazendeiro ou do senhor de engenho, que só vai à sua propriedade rural no momento do corte e da moenda da cana" (BASTIDE ${ }^{4}, 1978$, apud SANTOS, 2005, p. 21). A partir de então, as cidades passam a contar com uma vida urbana mais intensa, e que viria a efervescer apenas nas últimas décadas do século XIX.

Conforme verifica-se em Déak (2004), a urbanização brasileira iniciou-se após a constituição da "nação-Estado" e se intensificou a partir de 1850, com a promulgação da Lei das Terras e o término da importação de escravos, fatores esses que impulsionaram o trabalho assalariado e um aumento no número de habitantes nas cidades, uma vez que, instaurando a propriedade privada, o trabalhador precisa vender sua força de trabalho para poder garantir sua sobrevivência e morada. A cidade passa a ser polo de atração populacional, de pessoas em busca de trabalho e/ou mercadorias e também passa a ser o local de produção de grande parte delas, o que leva ao desenvolvimento de fábricas e indústrias, marcando o início do fenômeno da industrialização no país. Como relata Déak (2004, p.16), "o trabalho assalariado vale dizer, o desenvolvimento do capitalismo -, a industrialização e a urbanização não são apenas inseparáveis ou inter-relacionados: são um só processo."

Assim, conforme verifica-se em Santos (2005), enquanto ao final do Brasil Colônia o país possuía 2,85 milhões de habitantes e a população nas cidades representava 5,7\% do total, em 1872 são 5,9\% do total na área urbana e em 1900 já são 9,4\%, sendo mais de 1,2 milhões nas cidades, de um total de 14,3 milhões - em quinze anos, a população do país aumenta em 15\%. A urbanização como fenômeno

${ }^{4}$ BASTIDE, Roger. 1978. Brasil, Terra de Contrastes. São Paulo, DIFEL. 
fica evidente, porém, ao observar-se o período entre 1920 e 1940, quando o índice no país triplica - comparada ao intervalo 1890 e 1920 - chegando a 31,24\% (SANTOS, 2005, p. 25). No estado de São Paulo o processo é ainda mais expressivo, apresentando um índice de $43 \%$.

Nesse momento em que se estabelecerá a lógica da industrialização - e atrelada a ela, a urbanização - e o estado de São Paulo como polo e vetor desse processo - uma vez que concentrava uma dinamicidade econômica e social, além dos melhoramentos em infraestrutura pioneiros no país, advindos da produção do café e as mudanças econômicas geradas - conforme será destacado à frente, é também um momento de alterações políticas no país, que resultam em uma mudança estrutural quanto à governança, quando se tem a instauração do planejamento urbano como parte da agenda do Estado.

Como relata Monte-Mór (2008, p.34):

à medida que as forças modernas do capitalismo penetram os espaços econômicos subdesenvolvidos, vão sendo buscadas, na experiência do mundo desenvolvido, as abordagens existentes para os problemas gerados. O urbanismo no Brasil não foge à regra.

O país vivenciou inclusive a implantação de diversos planos e projetos, de diferentes correntes de pensamento, ao longo destes períodos, conforme observado em Campos (2002), Monte-Mór (2008), entre outros autores.

O desenvolvimento técnico e tecnológico relacionado aos transportes permitiu criar bairros mais distantes, algumas vezes deslocando a elite para fora do centro urbano econômico, outras vezes levando a população mais pobre a bairros periféricos, dando início a um modelo urbano centro-periférico de suas cidades.

Apesar dos diferentes contextos, a principal influência no processo urbanístico e de planejamento urbano brasileiro, ratificada com a construção de Brasília, se dá com o modelo progressista/racionalista, pautado pela técnica e estética definidos pelo Movimento Moderno, presente em um de seus principais documentos, a Carta de Atenas. A principal questão crítica a esse movimento é que ele acaba, através de sua organização pautada pelo zoneamento, por impor "autoritariamente um espaço urbano acabado que visa permitir um rendimento máximo no desenho das funções urbanas" (MONTE-MÓR, 2008, p.37). Ao tratar a cidade a partir de um viés industrial, defendem autores como Monte-Mór (2008), os planejadores utilizam perspectivas pautadas pelas relações de trabalho e estética na qual as "necessidades básicas dos 
homens são as mesmas" (MONTE-MÓR, 2008, p.36) ${ }^{5}$ em todo o mundo e então o urbanismo também o poderia ser.

Entre 1940 e 1980, como relata Santos (2005) o lugar de residência da população brasileira se inverte, com a taxa de urbanização passando de $26,35 \% \mathrm{em}$ 1940 a 68,86\% em 1980. "Nesses quarenta anos, triplica a população total do Brasil, ao passo que a população urbana se multiplica por sete vezes e meia" (SANTOS, 2005, p. 31), com os anos 1960 e 1970 representando o momento em que a população urbana supera a rural.

A década de 1930 marca o início de um período representativo no planejamento brasileiro do século XX, apresentando duas questões emblemáticas: a concentração nas metrópoles e tendo o Estado como principal agente. A mudança na organização política e a reforma administrativa vão colocar o planejamento na agenda de interesses do governo e o urbanista passaria então a uma mudança no perfil profissional, com forte participação no governo. Conforme relata Feldman (2008) apud Fernandes (2012), a criação do DASP (Departamento Administrativo do Serviço Público), em 1937, indica uma reforma administrativa em que se estrutura o urbanismo como prática profissional no país.

Além disso, os processos de industrialização promovem mudanças na sociedade e cidades brasileiras, gerando urbanização até mesmo onde não há concentração industrial, uma vez que deslocam trabalhadores, estabelecem mercados consumidores, aumentam a rede de transporte, entre outros. Assim:

$O$ quadro de transformações urbanas estruturais que caracterizava aquele momento, acoplado a um novo regime de acumulação, com grandes fluxos migratórios e de investimentos, particularmente imobiliários e de infraestrutura, ensejava a necessidade de enfrentamento da complexa questão urbana de forma mais articulada, indicando que a construção do urbanismo como política geral poderia constituir uma alternativa importante para o problema. (FERNANDES, 2012, p.52)

O urbanismo deixa então de estar ligado somente às práticas higienistas e tecnicistas, presentes nos Códigos de Posturas e Códigos de Obras e passa, a partir dos anos 1930, a ser influenciado pelos referenciais ingleses e, principalmente, americanos.

\footnotetext{
${ }^{5}$ Monte-Mór (2008) cita a tradução e transcrição de Choay (1979) - para a afirmação feita por Le Corbusier -: "Todos os homens têm o mesmo organismo, as mesmas funções. Todos os homens têm as mesmas necessidades".
} 
Com o período democrático e a Constituição de 1946, os municípios passam a ter maior autonomia, consagra-se a ideia de planejamento governamental, o zoneamento se estabelece como instrumento protagonista no planejamento brasileiro; surgem outros órgãos ligados a questões urbanísticas e de planejamento, como a Sociedade de Análise Gráfica e Mecanográfica de Complexos Sociais - SAGMACS (1947), o Instituto Brasileiro de Administração Municipal - IBAM (1952), o Centro de Pesquisas e Estudos Urbanísticos - CPEU (1955), que elaborará diversos Planos Diretores para municípios no estado de São Paulo e será de fundamental importância para Presidente Prudente.

Começam também, na década de 1950, as discussões acerca do planejamento regional, abrangendo para além da esfera municipal, que já estavam presentes nos Congressos Internacionais de Arquitetura Moderna (CIAM), nos Estados Unidos e Inglaterra. Como relata Mumford (1938), o planejamento regional é estratégico e se dá pela concentração de atividades em regiões definidas, delimitadas e que, se coordenadas, podem ter seu potencial aumentado.

No Brasil, o planejamento regional terá forte influência em políticas para a região Nordeste, região Amazônica, bem como para os estados da bacia do Rio São Francisco e do Paraná-Uruguai; estes últimos constituirão a Comissão Interestadual da Bacia Paraná-Uruguai - CIBPU (1951), que será responsável nas décadas de 1950 e 1960, principalmente, por projetos ligados a transporte fluvial e energia hidrelétrica.

A ideia de região transitará também em relação às cidades que funcionariam como centralidades para outras cidades menores. Essa perspectiva seria consolidada pela elaboração de um Projeto de Distrito Industrial para Presidente Prudente, dentro da política de polos de desenvolvimento, que segundo Santos (1965), era uma das formas essenciais para a realização de planos regionais, essa ação promotora sobre determinando cidades visava o fortalecimento da economia regional; este plano será abordado mais adiante.

Segundo Flávio Villaça, em sua análise em Uma contribuição para a história do planejamento urbano no Brasil, entende-se por planejamento urbano as "ações do Estado sobre o urbano que tenham sido objeto de algum plano, por mais amplo que seja o conceito de plano" (VILLAÇA, 1999, p.180) e não os pensamentos e teorias sobre o urbano, itens estes abordados no campo disciplinar do urbanismo.

Villaça (1999) distingue duas abordagens diferentes relacionadas a planejamento: o planejamento urbano lato sensu e o planejamento urbano stricto 
sensu; o primeiro tratando sobre um panorama geral e suas várias correntes e o segundo, como parte do primeiro, tratando sobre a época de implantação dos planos diretores integrados, que terá abordagem mais aprofundada neste trabalho pois influencia diretamente a análise do objeto desta pesquisa.

O autor convoca então, em sua análise, uma divisão do planejamento urbano brasileiro - lato sensu - nas seguintes correntes: planejamento urbano dos planos diretores integrados - strictu sensu -, o zoneamento, o planejamento de cidades novas e o urbanismo sanitarista. Antes de abordamos as questões dos planos diretores integrados, resumiremos algumas características das outras correntes.

Assim, o urbanismo sanitarista é uma das menores correntes a se disseminar pelo país e se resume, segundo Villaça (1999), no projeto de saneamento para a cidade de Santos, realizado por Saturnino de Brito. Por sua vez, o projeto das cidades novas inicia-se com a construção de Belo Horizonte, cuja inauguração ocorre em 1897. A partir dela, diversas outras cidades serão implantadas, muitas delas seguindo certas características baseadas em outros ideários de urbanismo - e não apenas no Moderno que tributa às raízes do CIAM, que inspiraria Brasília - mas outros de matriz ligada ao modelo Cidade Jardim como Goiânia e Maringá.

Quanto ao zoneamento, este talvez seja o mais difundido mecanismo de planejamento no Brasil, visto que se inicia ainda no final do século XIX, muito antes dos próprios planos diretores, como uma legislação para definir e regular certos usos ${ }^{6}$ e posturas nas cidades. Embora atualmente considera-se a inclusão do zoneamento no plano diretor uma prática, em outras épocas o zoneamento existiu por si.

No Brasil, a análise histórica do planejamento urbano pode ser dividida em três fases, segundo o autor: 1875 a 1930, de 1930 a 1990 e, por fim, o período atual, posterior à última década do século $\mathrm{XX}$ e em curso nos dias de hoje; algumas subdivisões também são apresentadas pelo autor.

A primeira fase é definida pelos planos de melhoramentos, provenientes da França haussmaniana, mas que se espalharam por todo o mundo e tiveram reflexos em muitas cidades. No Brasil, essa prática inspirou os planos das classes dominantes para o embelezamento monumental das nossas cidades, ganhando a expressão, por parte da esfera municipal, de "embelezamento urbano", e perdurou até os anos de 1940. Por trás dos nomes "embelezamento" ou "melhoramento" estava uma proposta

${ }^{6}$ Servindo a interesses das classes de mais alta renda em muitos momentos, conforme relata Villaça (1999). 
de planejamento, com várias ações implementadas, sendo datado o ano de 1875 como seu início pois trata-se do ano de lançamento de um plano geral feito para a cidade do Rio de Janeiro por uma Comissão de Melhoramentos, da qual Francisco Pereira Passos era membro.

As bases deste plano deram origem à reforma urbana feita por Pereira Passos, entre os anos de 1903 e 1906, quando ocupa o cargo de prefeito do Rio de Janeiro. A reforma propôs a abertura da Avenida Central, com a criação de um eixo monumental, e foi responsável por uma série de desapropriações, remoções da população, redefinição de vias, testadas, fachadas e tamanho dos lotes, tal qual ocorreu na reforma urbana de Paris, por Haussmann.

Em São Paulo, os planos de melhoramentos incluíram a remodelação do Vale do Anhangabaú, a construção de praças e aberturas de vias adjacentes ao vale, bem como a construção do Teatro Municipal. Ainda que o Plano Bouvard - assim conhecido por ser de autoria do francês Joseph-Antoine Bouvard, realizado a pedido do prefeito Barão de Duprat, e que incluía um parque para o Anhangabaú e outro para a várzea do Carmo - não tenha sido implementado em sua totalidade naquela gestão, Duprat sinalizou a "necessidade de que se garanta sua realização futura" (VILLAÇA, 1999, p. 198). Esse momento é considerado por Villaça como o advento que inaugura a articulação entre Urbanismo e do Plano Diretor, representando a segunda fase do histórico do planejamento urbano no Brasil.

A partir de 1930:

vem-se desenvolvendo no Brasil uma visão do mundo urbano segundo a qual os problemas que crescentemente se manifestam nas cidades são causados pelo seu crescimento caótico - sem planejamento -, e que um planejamento "integrado" ou "de conjunto", segundo técnicas e métodos bem definidos, seria indispensável para solucioná-los. Essa é a essência da ideologia do planejamento que ainda perdura. (VILLAÇA, 1999, p.183)

Segundo Villaça (1999), essa segunda fase da historiografia do planejamento urbano brasileiro, está compreendida entre os anos 1930 e 1990. A década de 1930 seria importante marco no qual ocorreriam mudanças no cenário político e econômico, com a burguesia urbano-industrial ascendendo ao poder, e a aristocracia rural perdendo seu domínio, é marcada por um planejamento urbano de afirmação, no qual a burguesia "necessitará sempre de produzir e reproduzir intensamente os mecanismos necessários à manutenção de sua dominação" (VILLAÇA, 1999, p. 202), 
uma vez que as classes mais baixas ganhavam consciência social. É o período do plano intelectual, que pretende impor-se e ser executado porque contém "boas ideias", tem base científica e é correto tecnicamente (VILLAÇA, 1999, p. 204).

Em 1930, são publicados planos para Rio de Janeiro e São Paulo respectivamente Plano Agache, por Alfred Agache e Estudo de um Plano de Avenidas para a cidade de São Paulo, por Prestes Maia - marcando o início da nova fase, na qual tais planos não falam somente sobre o embelezamento das cidades, mas abordam as questões estruturais, como transporte e saneamento, para toda a cidade.

A partir de 1965, segundo periodização proposta por Villaça (1999), tem-se início a fase dos superplanos, até 1971, nos quais a cidade não poderia ser analisada apenas por aspectos físicos, mas deveriam participar também os aspectos econômicos e sociais, assim como as instituições presentes na realidade urbana. Os superplanos apresentam-se como interdisciplinares e seu produto como um diagnóstico, com levantamentos, pesquisas e proposições legislativas. Esse período pode ser exemplificado pelos planos: Agache, Plano Doxiadis, PUB-SP e o Plano para a Região Metropolitana de Porto Alegre. O Plano Doxiadis, entregue ao governo no final de 1965, representa o apogeu durante os anos de atividade do Serviço Federal de Habitação e Urbanismo (SERFHAU). Além deste, outras entidades públicas surgiriam, assim como empresas privadas e institutos, e o superplanos marcariam o planejamento urbano de diversas cidades do interior do Brasil.

A crítica a estes planos se deu a partir de sua abrangência: eram extensos, muitas vezes realizados fora da realidade administrativa municipal, reuniam propostas complexas e que envolviam diversos setores - sendo, (des)integrados em muitos casos -, e ainda apresentavam como conclusões uma série de recomendações, que nem sempre estavam ao alcance de aprovação por parte do legislativo.

A última fase dessa periodização proposta por Villaça, conhecida como "Plano sem Mapa" inicia-se com a publicação da lei do Plano Diretor de Desenvolvimento Integrado (PDDI) de São Paulo, em 1971. Tratava-se de uma simples propositura legislativa, sem diagnóstico, nem mapas. É um plano de diretrizes descolado de quaisquer possibilidades de efetivação pois carece de instrumentos, meios para sua existência.

Nos anos de 1970, os planos passam da complexidade, do rebuscamento técnico e da sofisticação intelectual para o plano singelo, simples - na verdade, simplório - feito pelos próprios técnicos municipais, quase sem mapas (VILLAÇA, 1999, p. 221). 
Reunindo algumas ideias do autor, pode-se dizer que o planejamento urbano no Brasil, entre 1940 e 1990, é então tido como uma atividade de elaboração de planos diretores e que não conseguiu cumprir as funções a que se propôs. Os problemas estruturais e sociais das cidades se agravam cada vez mais, estruturais de gestão e liderança, a pressão dos interesses do Capital pelas grandes obras de infraestrutura e não mais as de embelezamento. Os planos sendo produzidos, mas sem efetividade ${ }^{7}$.

Após as décadas de 1970 e 1980, o planejamento começa a entrar em uma nova fase, ampliado pelo movimento de abertura política e fim do Regime Militar, com a participação e organização de movimentos populares e o início de um Movimento pela Reforma Urbana. A última fase do planejamento urbano proposta por Villaça teria início na última década do século $X X$, quando então se aprova a Constituição de 1988 e, com ela, a obrigatoriedade dos planos diretores para municípios com mais de 20 mil habitantes.

Um dos grandes avanços dessa Constituição estaria na possibilidade de avaliação das propriedades estarem cumprindo ou não sua função social e estarem sujeitas a sanções sucessivas e progressivas. Essas prerrogativas estariam previstas no Estatuto da Cidade, que deu entrada no Senado em 1989, mas só seria aprovado em 2001, pela Lei 10.257 de 10 de julho do referido ano.

Os planos diretores permanecem como exigência na legislação, sendo previstas revisões a cada dez anos e, com a disposição de que haja a implementação de planos participativos - que devem conseguir promover debates e diagnósticos junto às comunidades e camadas mais populares.

Indo além da década de 1990 até os dias atuais, o autor realiza uma crítica acerca da proliferação de planos, que agora são mais de um: além do plano diretor, planos de mobilidade urbana, planos e política de saneamento, plano de abastecimento de água, planos de manejo de resíduos, plano de drenagem urbana...

Por meio dos registros históricos apresentados sobre ações e processos, planos e projeto, o que se pode afirmar é que a realidade pela qual passam muitas de nossas cidades, no que tange aos aspectos urbanos e ambientais, é fruto de um processo de planejamento urbano, que se deram de forma geral ou pontual,

7 “É o planejamento urbano enquanto ideologia que dominará - e ainda domina - o planejamento urbano no Brasil" (VILLAÇA, 1999, p. 227). 
procurando em diferentes períodos ordenar regiões das cidades. Contudo, esse processo de ordenamento terminou por criar conflitos em áreas que, por exemplo, podem não ter sido parte direta do processo de planejamento, ou ainda, podem ter ficado ao largo deste, funcionando como a contra face de um processo que privilegiou um problema e causou outros. Por exemplo, a canalização de um rio, com retirada da população do entorno para a abertura de vias, pode ter deslocado essa população para outras regiões da cidade, gerando possivelmente um novo conflito em novas áreas, quase sempre, periféricas, nas quais os planos podem até estar presentes, mas as ações de projeto demoram a chegar... Isso sem mencionar que a ocupação das várzeas por marginais é uma ação que vai na contramão das expectativas sócio ambientais, provocando inundações e impedindo que a relação rio cidade se estabeleça.

É preciso reconhecer que cada época teve um planejamento urbano de acordo com o conhecimento técnico vigente; é claro que em alguns momentos foi possível fazer diferente, como veremos mais à frente, mas é então que firmamos um ponto fundamental: o processo de planejamento em pauta representava a ideologia de uma classe dominante, social e economicamente, que lançava mão de diferentes instrumentos para se manter no controle, como defende Villaça (1999).

\subsection{Considerações sobre a cidade brasileira}

A maior parte dos conflitos presentes na cidade brasileira atual reflete o modo de urbanização pelo qual passou o país e sua população, principalmente no século $\mathrm{XX}$ e das políticas governamentais desses períodos.

Segundo Santos (1996), vivemos o meio técnico-científico-informacional, no qual a relação histórica entre a sociedade e a natureza parte de um meio antes natural para outro cada vez mais artificial, baseado no domínio de técnicas, ciência e tecnologias, no qual mercado e produto tornam-se globais.

O meio, antes natural, no qual o homem escolhia da natureza o que necessitava, passa a um meio crescentemente artificioso no fim do século XVIII, quando o território se transforma, agora rapidamente, através da mecanização.

Esse meio técnico-científico (melhor será chama-lo de meio técnicocientífico-informacional) é marcado pela presença de ciência e da técnica nos processos de remodelação do território essenciais às produções hegemônicas, que necessitam desse novo meio geográfico para sua realização. A informação, em todas suas formas, é o motor 
fundamental do processo social e o território é, também, equipado para facilitar a sua circulação". (SANTOS, 2005, p. 38)

Alterando-se as relações de consumo e produção, altera-se também a dinâmica de produção do espaço urbano, a qual provoca mudanças nas relações socioespaciais e consequentemente na forma urbana das cidades e sua paisagem. Desse modo, estudar a forma urbana é premissa para o entendimento da cidade contemporânea, uma vez que:

A forma urbana é a expressão fundamental do espaço urbano, palco e resultado dos principais processos sociais - culturais, econômicos e políticos - da escala do cotidiano à escala das ações de diferentes atores hegemônicos (MACEDO et al, 2012, p.154)

E, segundo, Spirn:

O ambiente natural de uma cidade e sua forma urbana, tomados em conjunto, compreendem um registro da interação entre os processos naturais e os propósitos humanos através do tempo. Juntos, contribuem para a identidade única de cada cidade. (SPIRN, 1995, p. 28)

A forma urbana não tem existência autônoma e constitui-se pela relação entre os espaços livres e edificados, públicos e privados, legais e ilegais, acolhedores ou excludentes (MACEDO et al., 2012) e permite a identificação e análise dos tecidos urbanos e suas tipologias, padrões de parcelamento, bem como sua participação na conformação dos espaços livres. Entender a forma urbana e o sistema de espaços livres possibilita-nos o conhecimento da esfera de vida pública e sua espacialidade:

Desde os primórdios da existência das cidades os espaços livres urbanos vêm se constituindo em importante elemento para a vida citadina. [...]. Em qualquer que seja a formação urbana, ocidental ou oriental, das menores cidades às megalópoles, o reconhecimento sistêmico do conjunto de espaços livres de cada uma delas se constitui em si, importante fator para análise, diagnóstico, proposição e gestão dos espaços livres, notadamente para os espaços públicos. (QUEIROGA; BENFATTI, 2007, p. 81-82)

Nas cidades brasileiras, que apresentaram maiores taxas de urbanização a partir da década de 1950 - com a intensificação do processo de industrialização -, e onde vivem atualmente $84 \%$ da população do país - de acordo com dados do Censo Demográfico do IBGE (2010) - pode-se dizer que:

Tem-se como princípio que a forma urbana em especial das cidades de médio e grande porte está em constante processo de transformação e expansão e que a cada ciclo socioeconômico novas 
manifestações são associadas às estruturas existentes tanto pela substituição de estruturas como pela construção e adição de novas. Enfatizam-se os processos contemporâneos de dispersão urbana física e funcional, de verticalização, da construção constante de estruturas viárias de porte, da expansão das áreas de lazer metropolitanas e urbanas além de seus limites físicos, a suburbanização acentuada e as questões ligadas à conservação e preservação de elementos naturais e à dinâmica ecológica. (CUSTÓDIO et al., 2013, p.01)

Além dos processos atuais correntes nas cidades brasileiras, a mancha urbana sofreu - e ainda sofre - forte influência da introdução de legislações específicas, algumas já citadas:

a) Lei № 4.771, de 15 de setembro de 1965, que instituía o Código Florestal, alterada pela:

b) Lei $N^{\circ} 12.651$, de 25 de maio de 2012, que dispõe sobre vegetação nativa, mais conhecida também como Código Florestal.

c) Lei № 6.766, de 19 de dezembro de 1979, que dispõe sobre 0 Parcelamento do Solo Urbano, com alterações recentes dispostas na:

d) Lei № 9.785, de 29 de janeiro de 1999;

e) Lei № 10.257 , de 10 de julho de 2001, mais conhecida por Estatuto da Cidade, que estabelece diretrizes gerais para a política urbana e o pleno desenvolvimento das funções sociais da propriedade e cidade a partir de instrumentos urbanísticos;

Faz-se necessário compreender o surgimento e o processo de crescimento das cidades, as qualidades de seu desenvolvimento, bem como o impacto gerado pelos novos modelos urbanísticos - loteamentos e condomínios fechados -, áreas industriais - que antes centrais, afastam-se do centro à procura de terra mais barata e fácil acesso às estradas -, verticalização - que se afasta do centro consolidado e se espraia-, sem contar a reflexão necessária acerca do estoque de terras públicas formado a partir da legislação das APP (Áreas de Preservação Permanente) e das leis de parcelamento -, que passam anos sem projeto e ocupação, destratadas pelo poder público.

Não podemos deixar de mencionar o impacto causado pelo aumento na frota de veículos, que leva à ampliação constante da rede viária priorizando o automóvel, 
transformando muitos espaços livres - em grande parte fundos de vale - em sistemas de circulação; bem como as dinâmicas habitacionais populares através de programas que criam enormes bairros periféricos, na maioria das vezes, estabelecidos às margens da mancha urbana consolidada.

Os novos modos de produção e apropriação do espaço citados acima, aparecem não somente nas metrópoles e capitais, mas também em cidades médias, que funcionam como espelho da metrópole, refletindo semelhanças (verticalização, industrialização, loteamentos fechados, priorização do transporte individual) e apresentando peculiaridades e especificidades a que cabem estudo e análise.

Em A Revolução urbana - La Révolution urbaine, originalmente publicado em 1970 - Henri Lefébvre introduz o segundo parágrafo do terceiro capítulo com uma sentença ainda pertinente nos dias atuais: "Hoje, o fenômeno urbano nos surpreende por sua escala; sua complexidade supera as ferramentas de nossa compreensão e os instrumentos de atividade prática"8 (LEFEBVRE, 2003, p. 45, tradução nossa).

Ainda que se tenha desenvolvido uma série de instrumentos e ferramentas ao longo do século para compreendê-lo, entender o fenômeno urbano ainda é um desafio - uma vez que se trata de um processo ainda em curso e, especialmente, seu estudo atual inclui a dimensão social e de processo de modo inalienável, pois como relata Lefebvre na conclusão da obra supracitada, é necessário conhecer o usuário, entender suas dificuldades e suas relações com o próprio fenômeno, e não excluí-lo do processo, como ainda se faz muitas vezes ao lidar com as questões teóricas, propositivas e práticas do urbanismo - e do planejamento urbano.

Por mais que os planos diretores atuais devam ser participativos desde a aprovação do Estatuto das Cidades (2001), é necessário que as classes participem não somente do processo de feitura do plano, mas dos processos de planejamento e gestão como um todo. É necessário que se faça perguntas à cidade, e que se busquem respostas: na sua história e na história dos que dela fazem parte. Uma vez que:

A cidade é, ao mesmo tempo, uma região e um lugar, porque ela é uma totalidade, e suas partes dispõem de um movimento combinado, segundo uma lei própria, que é a lei do organismo urbano, com o qual se confunde.

$[\ldots]$

8 "Today, the urban phenomenon astonishes us by its scale; its complexity surpasses the tools of our understanding and the instruments of practical activity" (LEFEBVRE, 2003, p. 45). 
Assim, nos é permitido dirigir perguntas à cidade, indagando a respeito de sua formação, já que a história da cidade é a história de sua produção continuada. A história de uma dada cidade se produz através do urbano que ela incorpora ou deixa de incorporar [...]. (SANTOS, 1994, p. 71)

\subsection{0 contexto de um planejamento regional para o estado de São Paulo e as cidades médias}

O fenômeno da urbanização brasileira e sua intensificação, no século passado, provocaram, como relatado, a explosão demográfica de cidades e trouxeram também conflitos e questões entre o processo de ocupação e desenvolvimento e o meio físico.

A urbanização não esteve restrita apenas às capitais das províncias: o país se urbanizava e cidades menores também passaram por um processo de crescimento populacional e econômico, despontando como centros de determinadas regiões, dentro de uma relação direta com cidades maiores, mas também com as cidades menores do seu entorno (centros urbanos estes que mais à frente denominaremos de cidades médias). O estado de São Paulo - ainda província no final do século XIX e início do século $X X$-, pela situação econômica na qual se encontrava, foi um grande exemplo dessa expansão e crescimento de cidades.

No século XIX, a vinda da família real portuguesa e a abertura dos portos, em 1808, somadas à Independência, em 1822, à Lei das Terras, em 1850, e à Lei Áurea, em 1888, provocaram transformações econômicas sem precedentes. O café, produzido inicialmente no Vale do Paraíba, foi deslocando-se e adentrando outras regiões do estado, nas quais encontrou as condições ideais para seu pleno desenvolvimento e produção; em meados do século XIX, o café já representava mais de $70 \%$ do valor das exportações brasileiras.

Para escoar a produção, incentivou-se a construção de ferrovias, que levavam a produção do interior do estado até o Porto de Santos, passando por São Paulo, em muito menos tempo. Em 1867, a Estrada de Ferro Santos-Jundiaí foi inaugurada; em seguida, em 1872, o trecho entre Jundiaí e Campinas. A Companhia Paulista construiria ainda as redes de ferrovia Ituana (1873), Mogiana (1875) e a Sorocabana (1879). Em 1877, São Paulo passaria também a ter uma ligação direta com o Rio de Janeiro, pela Estrada de Ferro do Norte. A província de pouca importância - no início do século XIX - estava, a partir de então, conectada ao interior de seu território e 
também à capital do país, por uma rede de trilhos, e se tornaria o centro econômico do país graças às lavouras cafeeiras. Em 1920, as ferrovias já atingiam todas as regiões do estado.

Mas, muito além de escoar a produção das lavouras, o desenvolvimento da rede ferroviária foi responsável pelo crescimento no número de cidades, que se desenvolviam ao longo dos trilhos e estações, colaborando com o movimento de expansão da urbanização e a implementação de uma rede urbana. Segundo Matos (1990), no período compreendido entre os anos de 1900 e 1930, cento e vinte novas cidades surgiram no estado.

A partir das consequências geradas pela Crise mundial de 1929 e a queda das exportações de café, e as mudanças políticas nacionais a partir de 1930, iniciase o processo efetivo de industrialização do país, com investimentos e política de incentivo por parte do governo. Assim, mesmo com a crise nas lavouras do café, o estado concentrava uma riqueza econômica considerável advinda da sua produção e comercialização, e que estava disponível para integrar o capital industrial, representando naquele momento solução econômica à crise de 1929. Como relatado anteriormente, este período coincide com a implementação de novas frentes do planejamento urbano no país, gerenciadas principalmente pelo Estado, abordando questões estruturais como saneamento e transporte.

Como relata Tavares (2017), a industrialização, por ser uma atividade predominantemente urbana, gerou urbanização no estado e esta também proporcionou aquela; assim:

Do ponto de vista territorial, a indústria no estado de São Paulo acentuou as bases urbanas e fez deslanchar um processo inevitável e irreversível de aumento da população nas cidades e da formação de polos atrativos (SILVA, 1976) de serviços e atividades diversificadas que, por sua vez atraiam mais indústrias. (TAVARES, 2017, p. 05)

A atividade industrial, porém, criava uma nova necessidade de deslocamento de produtos e matérias-primas, que integrasse as cidades, a produção, a população e os mercados consumidores; as ferrovias, que se deslocavam quase que exclusivamente entre o interior e a capital e dela até o porto de Santos, não atendiam a demanda de deslocamento do novo fenômeno e então o modelo rodoviário passa a ser pensado e posto em prática.

Como relata Tavares (2007), a partir de 1913, com o "Plano de Viação" para o estado e posteriormente, entre 1920 e 1940, com a idealização de uma rodovia Pan- 
americana, a estrutura rodoviária estender-se-ia pelo estado, em uma trama radial que conectaria a capital às outras regiões do interior paulista e do país, seguindo a hidrografia, a urbanização e as vias férreas já implantadas.

Essas estradas, concebidas e construídas com a finalidade de interligar as principais cidades do Interior do estado, reforçaram a importância desses centros urbanos evidenciando-os como nós de uma rede produtiva. Essa importância dos centros urbanos do interior paulista foi reforçada pelas reformas administrativas dos anos seguintes. (TAVARES, 2017, p. 06)

As reformas administrativas às quais se refere Tavares (2017) são as já abordadas reorganizações administrativas promovidas na Era Vargas, que a partir de 1938 promoveu uma divisão político-administrativa na qual os municípios ganharam destaque como protagonistas, instituindo também a ideia de comarca, ao estabelecer municípios dentro de uma região administrativa. Somadas às reformas promovidas no estado de São Paulo em 1935 por Armando Salles de Oliveira - que reorganizou administrativamente o território estadual, criando novos órgãos e promovendo sua autonomia no planejamento -, pode-se dizer que houve uma mudança estrutural no país, instituindo-se um processo de regionalização e de centros urbanos que passaram a ser núcleo principal das novas instâncias e esferas - políticas, econômicas, jurídicas (TAVARES, 2017).

Nos anos seguintes, nas décadas de 1940 e 1950, outros planos rodoviários, estaduais e nacionais, buscariam articular a capital, que já somava metade da produção industrial no país (CANO; GUIMARÃES NETO ${ }^{9}$, 1986, apud TAVARES, 2017) a essa rede de cidades que formavam uma nova rede urbana. Além destes planos, a partir da institucionalização do planejamento urbano por parte do Estado, outros foram traçados visando a busca por um desenvolvimento mais equilibrado, no qual a indústria se espalhasse pelo interior, dinamizando a economia das cidades, retendo população nestes centros urbanos e buscando equacionar o desenvolvimento entre capital e interior.

A regionalização do território paulista seria abordada nos estudos produzidos: pela SAGMACS em 1953, no âmbito das questões solicitadas pela CIBPU, recomendando no estudo "Problemas de Desenvolvimento - Necessidades e

9 CANO, Wilson; GUIMARAES NETO, Leonardo. A Questão Regional no Brasil: traços gerais de sua evolução histórica. In: Pensamiento Iberoamericano. Economia PoliticaMadri: Instituto de Cooperation Iberoamericana, n. 10, p. 167-184, 1986. 
Possibilidades do Estado de São Paulo" a "descentralização das indústrias orientada pelos principais polos de cada região sob as justificativas do potencial natural, da preexistência de atividade industrial e da urbanização dessas regiões" (TAVARES, 2017, p. 09); por Anhaia Mello, em 1954, no "Plano Regional de São Paulo", que proporia a desconcentração industrial da capital propondo novas áreas industriais em um raio de 100km; e por Carvalho Pinto, em 1959, no "Plano de Ação do Governo", que procurou descentralizar a administração pública, levando ao interior órgãos e serviços públicos relacionados à infraestrutura.

Assim, na década de 1960, "consolidou-se no estado de São Paulo o padrão de organização territorial pelos eixos rodoviários e pelos polos urbanos" (TAVARES, 2017, p. 10), com estes sendo estabelecidos pelo Decreto Estadual 48162/1967. O decreto estabelecia dez regiões geográficas de organização territorial no estado de São Paulo, cada uma com uma cidade sede de região, e que era responsável por coordenar e conectar as políticas estaduais aos municípios pertencentes a sua divisão.

Como polo urbano foi considerada a principal cidade de uma região que pela relação de interdependência social e econômica com as cidades circunvizinhas delimitava um raio de influência capaz de definir um aglomerado de cidades a ela subordinadas. (TAVARES, 2017, p. 12)

Nos anos 1970, segundo o mesmo autor, o governo estadual vincula sua política de desenvolvimento econômico e administrativo a partir da regionalização de seu território; programas como "Ação Regional" (1971), estabeleceram ações de planejamento urbano e desenvolvimento industrial em cidades no interior do estado, em ações como "Balcão de Projetos" (1974) - que estipulava uma espécie de tutorial para implementação industrial no interior - e "Cidades Médias" (1977) - que direcionava a 40 cidades médias recursos e verbas para infraestrutura, bem como para a demarcação e implantação de distritos industriais previstos em seus planos diretores e no projeto Balcão de Projetos.

Na década de 1980, "motivado pelas crises internacional e nacional e pelo sucessivo enfraquecimento político das instituições democráticas de planejamento, a escala regional tornou-se secundária frente a uma política estadual que se voltava a escala local" (TAVARES, 2017, p. 15), sendo a Política de Desenvolvimento e Desconcentração Industrial (PDDI) e a Política de Desenvolvimento Urbano (PDU) as 
ações postas em práticas e que exemplificam essa alteração da escala regional para a local.

Com essas políticas, que em geral procuravam a desconcentração industrial e sua distribuição pelo estado, buscando aumentar os ganhos e evitar gastos maiores com burocratizações e legislações restritivas de uso, os programas atribuíam maiores vantagens a regiões e cidades mais desenvolvidas e menores às menos desenvolvidas, provocando como resultado a "qualificação de uma porção do estado e o consequente subdesenvolvimento de outras regiões localizadas nos cones de fronteiras, caracterizadas pelo Vale do Ribeira e pelo Pontal do Paranapanema, historicamente conhecidos por "Regiões Problemas" (CIBPU, 1968)10." (TAVARES, 2017, p. 16).

Os programas do governo e ações de planejamento territorial urbano e regional tiveram certo êxito: "a interiorização ocorreu e legou um padrão de urbanização espraiado, ou disperso (REIS, 2006) ${ }^{11}$. A participação na produção industrial nacional da Região Metropolitana de São Paulo passou de 44\% (1970) para 25\% (1997) e a do emprego nas atividades industriais, no mesmo período, de 34\% para 24\%" (TAVARES, 2017, p.16) e o estado de São Paulo vivenciou, entre os anos de 1910 e 1980, um processo de urbanização e industrialização na chamada Região dos Vetores Produtivos (TAVARES, 2017); que é essa porção territorial na qual se conectam polos urbanos e eixos rodoviários - e na qual foram empenhadas as ações de planejamento ao longo do século XX que não formaram uma nova e única região econômica, mas consolidaram diversas regiões e centros urbanos em um território dinamizado, sendo responsáveis por definir a estruturação urbana e uma hierarquia de escalas entre regiões e cidades do interior do estado, as quais, excetuando as regiões metropolitanas, são analisadas com maiores detalhes por uma rede consolidada de pesquisadores: as cidades médias.

As cidades médias são assim denominadas pelo papel de intermediação e importância que desempenham em sua rede urbana (SPOSITO, 2001) e não somente por seu tamanho demográfico - as cidades de porte médio são aquelas que apresentam população entre 100 mil e 500 mil habitantes. São cidades que não fazem

\footnotetext{
10 CIBPU. A Regionalização do Estado de São Paulo. Versão Preliminar. Documento datilografado da Comissão Interestadual da Bacia Paraná-Uruguai, Departamento de Planejamento Econômico e Social, elaborado por Paulo Yokota, maio, 1968.

${ }^{11}$ REIS FILHO, Nestor Goulart. Notas sobre urbanização dispersa e novas formas de tecido urbano. São Paulo: Via das Artes, 2006.
} 
parte de regiões metropolitanas mas participam regionalmente como articuladoras entre as metrópoles e as cidades pequenas, em uma hierarquia complexa. Em sua conceituação "deveríamos considerar os papéis desempenhados pelas cidades em uma divisão de trabalho interurbana e as suas formas de expansão e aglomeração urbanas como indicadores de sua caracterização" (SPÓSITO, 2001, p. 235). Sposito (2001) e Savério Sposito (2007) sugerem que a análise dessas cidades e suas dinâmicas e mudanças devem considerar os fluxos intraurbanos - pensando sua reestruturação devido a sua contínua transformação - e os fluxos interurbanos, uma vez que seus processos atingem um território que constitui uma rede urbana.

Assim, podemos afirmar que as cidades médias se definem por sua situação geográfica em relação às outras cidades de mesmo porte, pela distância maior ou menor das cidades de maior porte, e pelo número de cidades pequenas que estão em sua área de influência. Além disso, os seus papéis dependem da forma como o território que comandam e representam participa da divisão do trabalho. Por essas razões, as cidades médias desempenham papéis segundo relações hierárquicas com as cidades pequenas que se servem dos bens e serviços por elas oferecidos, e com as cidades grandes que desempenham papéis de integração nacional ou internacional. (SAVERIO SPOSITO, 2007, p. 9).

Grande parte das cidades médias no estado de São Paulo teve seu desenvolvimento baseado na industrialização, ainda no começo do século $X X$, propiciado pela expansão da rede ferroviária - para o norte, oeste e noroeste - e proximidade a fontes de matéria prima. Entre altos e baixos, a industrialização nessas cidades voltou a crescer, segundo Savério Sposito (2007) e Tavares (2017), a partir da década de 1970, liderada por um processo de descentralização industrial na capital, que enfrentava elevação de custos de aglomeração na Grande São Paulo, perda de competitividade, modernização da agricultura e uma política estadual de construção de uma malha viária ampla, diminuindo os custos e apresentando novas vantagens para a localização industrial.

Maria Encarnação Beltrão Sposito e Eliseu Savério Sposito abordam em seus trabalhos que estas cidades, que passaram por um processo de estruturação urbana ao longo do século passado, atualmente enfrentam um processo de reestruturação, com a "constituição de centros e centralidades segundo as mesmas lógicas e interesses que comandam esse processo na metrópole" (SAVERIO SPOSITO, 2007, p.10), mas com ritmo e intensidade diferentes. 
Além dos modelos comerciais e de serviços, das novas centralidades e subcentros, do surgimento de shopping centers, dos novos eixos comerciais, da alteração nos deslocamentos e meios de transporte da população, que correspondem às formas de consumo e apropriação do espaço urbano, as cidades médias passam por novos processos de produção deste espaço - com distritos industriais, condomínios fechados - que apresentam semelhanças e guardam especificidades em relação aos processos que ocorrem nas metrópoles.

Assim, verifica-se nas cidades médias:

[...] uma homogeneização das paisagens citadinas, que imitam cada vez mais as metropolitanas, mesmo que haja diferenças entre as práticas sociais e a magnitude dos papéis desempenhados pelas cidades intermediárias. Os loteamentos fechados, por exemplo, têm sido os produtos de maior impacto no mercado imobiliário de cidades latino-americanas, nas últimas décadas.

Além disso, a instalação de "distritos industriais" [...] contempla a complexidade da reestruturação das cidades médias no momento atual.

Assim, no anel periurbano formado por glebas não loteadas apareceram, nos setores melhor servidos por infraestrutura viária, novos habitats urbanos e novas instalações industriais com diferentes graus de incorporação tecnológica, trazendo à periferia da cidade um desenho territorial que não Ihe era característico nas décadas de 1950 e 1960, quando o padrão geral de periferização do tecido urbano se generalizou. [...]. Assim, uma nova dinâmica instaura-se no processo de produção da cidade: é a articulação entre diferentes processos que definem como a estrutura urbana vai se reorganizar. Desse ponto de vista, o reconhecimento de uma nova morfologia urbana é indicativo que se vive um processo de ruptura no movimento de estruturação e que, portanto, há reestruturação dos espaços urbanos. (SAVÉRIO SPOSITO, 2007, p. 10-11).

Essa homogeneização das paisagens e processos relaciona-se também aos conflitos entre a ocupação humana e urbana e o meio físico, entre a cidade e a natureza, abordados ao longo deste capítulo. Grande parte dessas cidades médias sofreram um processo de ocupação que interveio severamente no espaço, eclipsando córregos, suprimindo áreas de vegetação nativa, ocupando margens de rios e fundos de vale, impermeabilizando o solo.

A questão que se apresenta aqui é: se o processo é semelhante ao já analisado e encontrado em outras cidades e metrópoles, como a própria cidade de São Paulo, já abordada, por que, então, estudar cidades médias?

A metrópole é, também, natureza transformada, coisificada, vendida aos pedaços, ainda que sempre natureza.

No caso das cidades pequenas e médias, esta interface é muito mais forte, porque são cidades com níveis menos amplos de interações. 
São cidades que, a meu ver, ainda nos possibilitam, pelo tamanho que têm, um tratamento mais adequado da natureza, bem como exigem reconhecimento de uma consciência maior sobre o fato de que a cidade é natureza, para superar aquela ideia de que a natureza está fora cidade. Então quando eu falo par de articulação não é a cidade de um lado e a natureza de outro, mas é a própria compreensão de que a cidade é natureza e de que, sem sombra de dúvidas, são os processos de produção do espaço urbano os que mais estão interferindo, desconhecendo, negligenciando a dinâmica dos processos naturais. (SPOSITO, 2009, p. 17 e 18)

Nesse contexto insere-se Presidente Prudente, polo regional desde a década de 1960, que estabelece relações com cidades vizinhas menores, com a capital do estado, com outros polos regionais e até mesmo com outros estados, devido a sua posição geográfica estratégica. Como veremos mais à frente, Presidente Prudente esteve envolvida nas ações de planejamento urbano e planejamento regional por parte do estado ao longo do século passado, e a cidade e sua paisagem atual, seja por seus conflitos ou congruências, foram fortemente influenciados por esse modelo de desenvolvimento descrito neste capítulo - origem nas lavouras de café, linhas férreas, processo de urbanização, conflitos entre cidade e meio físico, desenvolvimento local, eixos rodoviários, industrialização, estruturação urbana, planejamento urbano, planejamento regional, polo de desenvolvimento, cidade média, disseminação de modelos metropolitanos de consumo, apropriação do espaço e produção do espaço, espraiamento urbano, modelo centro-periférico, acentuação dos conflitos entre cidade e natureza, reestruturação urbana - e são parte desse processo de planejamento.

Cabe desse modo, descrever esse processo histórico tendo em mente 0 recorte estabelecido por esse trabalho. Através de seu processo de urbanização, procurar explicitar os conflitos estabelecidos entre o meio físico, bem como o comprometimento da relação rio cidade, ao mesmo tempo em que as lógicas contemporâneas de desenho e ocupação do território podem nos informar alternativas e revelar potencialidades de um futuro construído sobre bases mais sustentáveis de desenvolvimento. 


\section{CAPÍTULO II - PLANEJAR COM A PAISAGEM}

Mas a natureza na cidade é muito mais do que árvores e jardins, e ervas nas frestas das calçadas e nos terrenos baldios. É o ar que respiramos, o solo que pisamos, a água que bebemos e expelimos e os organismos com os quais dividimos nosso hábitat. [...] [A natureza na cidade] É a consequência de uma complexa interação entre os múltiplos propósitos e atividades dos seres humanos e de outras criaturas vivas e dos processos naturais que governam a transferência de energia, o movimento do ar, a erosão da terra e o ciclo hidrológico. A cidade é parte da natureza. (SPIRN, 1995, p. 20, grifo nosso)

\subsection{Planejar com a paisagem - um percurso histórico}

Ao longo de sua existência, os seres humanos ocuparam e transformaram o planeta produzindo mudanças em sua paisagem, das quais as cidades provavelmente sejam um dos maiores impactos e dos mais notáveis produtos da vida em sociedade. Como relata Anne Whiston Spirn, no prólogo da versão traduzida para o português de O Jardim de Granito12, "dificilmente um ponto sobre a terra, por mais remoto que seja, está livre do impacto da atividade humana" (SPIRN, 1995, p. 20).

Ainda segundo a autora, cidade e natureza foram colocadas uma contra a outra ao longo dos processos de construção da vida urbana e os principais conflitos enfrentados - poluição, enchentes, escassez de recursos -, e que se intensificaram nos últimos séculos, são resultados diretos deste pensamento de que a cidade não é parte da natureza.

Assim, este capítulo procura trazer a abordagem de que estas duas dimensões não são separadas e também discutir teorias e práticas que, desde o século XIX, mostram que as cidades podem - e precisam - ser projetadas como parte integrante da natureza e que esta não é apenas um embelezamento artificial ou artigo de luxo, mas uma "força essencial que permeia a cidade" (SPIRN, 1995, p. 21).

A ideia de um planejamento territorial - tratando questões ecológicas a partir da noção de região - que trouxesse o campo para a cidade foi apresentada por Patrick Geddes em seu livro Cidades em Evolução, que publicado em 1915, critica o crescimento excessivo das cidades inglesas e os problemas gerados pela industrialização e como estes afetaram o acesso a recursos naturais e causaram

${ }^{12} \mathrm{O}$ Jardim de Granito, de autoria de Anne Whiston Spirn, foi publicado originalmente como The Granite Garden: Urban Nature and Human Design. 
prejuízos à saúde da população, que vivia em um ambiente de trabalho e urbano insalubres e não tinha acesso à natureza (HALL, 1995).

Segundo Gueddes, o aumento da população necessitava de um acesso pleno ao campo e à vida campestre, ao mesmo tempo em que estes espaços devem ter maior importância e área dentro da municipalidade.

A saúde sem as alegrias da vida - das quais o acesso à natureza é o
primordial - não passa de aborrecimento; e isso conduziria a doenças
insidiosas. Junto com a preservação, vem a cultura de áreas florestais:
não o simples plantio de árvores, mas a silvicultura, a arboricultura e
a formação de parques, que é a sua maior e mais bela forma.
Essa visão sinóptica da Natureza, essa conservação construtiva de
sua ordem e beleza, visando a saúde das cidades e a felicidade
simples e viva de seus turistas (a quem a cidadania vai sabiamente
educar pela aceitação e nunca pela exclusão), é mais do que
engenharia: é uma obra de arte: maior do que a do planejamento de
ruas, é a prática do paisagismo; e assim, ela se integra ao
planejamento urbano. (GEDDES, 1994, p. 83)

Considerado por autores como Peter Hall um precursor do planejamento regional, Geddes (1994) direciona seus estudos sobre a cidade a partir de suas regiões naturais, levantando as florestas, áreas verdes, mananciais e fontes de água, entre outros; em sua obra, já em 1915, trabalha com mapas de demografia, afirmando sua importância e utilidade para a análise urbana; demonstra ainda a preocupação quanto ao acesso de água potável visto que os rios que cortavam as cidades já se apresentavam em condições desfavoráveis ao consumo.

Ao analisar o crescimento da grande Londres e sua expansão ao longo das "linhas" (estradas de ferro, cabos telegráficos), critica a falta de espaços abertos entre elas e afirma que uma rede de cidades não deve ser supercentralizada, para evitar que se repitam os erros de desenvolvimento e os problemas da grande Londres.

As grandes cidades vizinhas estão sendo ligadas pelas linhas de bondes, traçados de ruas, estradas de ferro, enquanto grandes espaços abertos que deveriam, ainda há pouco tempo, ter sido preservados como inigualáveis pulmões de vida, já são irrecuperáveis (GEDDES, 1994, p. 34).

Nesse momento em que considera grupos urbanos e cidades menores, permeadas por espaços abertos e de natureza, Geddes aproxima sua obra das ideias presentes na teoria da cidade-jardim, de Howard, que publicara em 1898 o livro Tomorrow: a Peaceful Path to a Real Reform. 


\subsubsection{Cidade-Jardim}

Contemporâneo a uma época conhecida como Revolução Industrial, na qual a força do trabalho, antes predominantemente manual, passa a ser exercida em parte por máquinas, com a relação mestre/artesão perdendo cada vez mais espaço, dá-se o crescimento das cidades, e as áreas urbanas tornam-se locais de concentração das indústrias e serviços. Temos aqui um movimento coetâneo que associa êxodo rural e cidades como polos de atração populacional, com um movimento cada vez maior dos campos, sendo a Inglaterra precursora dessa revolução, Ebenezer Howard vivenciava uma cidade - Londres - de ambientes opostos e contraditórios.

De um lado, a burguesia, ascendente através da política de liberalismo e práticas mercantilistas, que se associa estrategicamente à nobreza para habitar espaços arborizados e bairros elegantes construídos nos arredores da área central (OTTONI, 1996). Nesse modelo que inaugura uma nova fisionomia de cidade há predomínio do verde, praças e jardins arborizados e valorização dos espaços livres e abertos, com parques seguindo o desenho naturalista inglês, sinuoso, bucólico, pinturesco. Esses novos bairros passam a abrigar muitos donos das crescentes e numerosas fábricas.

Do outro lado, a cidade marcada pelo avanço da era industrial que, baseada na exploração do carvão, do desenvolvimento do vapor, maquinaria, mercadoria barata para manter mão de obra a baixos custos gerou cidades com numerosa população, baixíssimos padrões de vida, bem como solo limitado para agricultura; em resumo, uma cidade miserável (GEDDES, 1915). Essa situação foi agravada no último quarto do século por uma crise comercial, a partir do aumento da oferta de produtos devido à industrialização de outras nações; para equilibrar a balança e continuar lucrando, recuperação que ocorreu a partir de 1880, os industriais apostaram nas exportações, principalmente para a América do Sul, e, investindo nesses mercados, deixou de aplicar os lucros para melhorias na qualidade de vida de suas próprias cidades.

Porém, esses acontecimentos não se restringiam a Londres:

No século XIX a Revolução Industrial deixou outras profundas e bem conhecidas marcas nas cidades europeias: pelo inédito aumento de suas populações, da poluição do ar e dos cursos d'água, de grades problemas de higiene e consequentemente da enorme deterioração do ambiente urbano. É na habitação dos operários e da massa dos sem-trabalho que se vê obrigada a deixar o campo e as cidades de 
pequeno porte para procurar melhor sorte, que os resultados são contundentes. [...] Com frequência, as habitações operárias situavamse em vielas estreitas, sem contar com iluminação e ventilação razoáveis. (OTTONI, 1996, p.18)

Com o surgimento das ferrovias, o limite da cidade moderna passa a ser o tempo de viagem (GEDDES, 1915) - o tempo máximo que os trabalhadores podem enfrentar sem grandes reduções no seu dia de trabalho; a cidade se expande ainda mais: conurbações e subúrbios disparam em números. Em 1851, Londres possuía população de 2,3 milhões de habitantes; em 1891, atingiria 4,2 milhões de moradores na cidade e 5,6 milhões contando com os subúrbios (OTTONI, 1996).

Alegando a insustentabilidade desse modelo de crescimento e seu impacto na cidade (falta de saneamento, ventilação, iluminação, poluição, epidemias...) e inconformados com as péssimas condições de vida (habitação, condições de trabalho, vida social e financeira) de grande parte da população, principalmente a operária e aquela proveniente das áreas agrícolas, muitos dos quais sem ocupação, alguns empresários, industriais e políticos, embasados nas ideias de pensadores e teóricos de matriz humanista, buscam desenvolver novas formas de ocupação, criando bairros operários e até novas cidades, pautadas por certo rigor de planejamento e oferecendo melhores condições de vida, de educação e de trabalho aos operários e suas famílias.

Como relata Ottoni (1996), Robert Owen, na Escócia, além de modernizar sua fábrica e propor melhores condições aos empregados, bem como moradia, cria ainda, em 1817, uma cidade, com bases na indústria e agricultura, para 1200 habitantes; por suas ações, foi considerado um pioneiro do cooperativismo e socialismo. Na França, Charles Fourier propõe, em 1822, a ideia dos falanstérios, com uma comunidade para 1600 pessoas, rodeado por terras cultiváveis e tem sua ideia desenvolvida em Guise por Jean-Baptiste Godin, que aloja as famílias em três edifícios para habitação, os familistérios. Outros exemplos, semelhantes às ações de Owen em New Lanark, criam comunidades e cidades junto a suas fábricas, as quais foram denominadas company towns, são: Saltaire (1853, criada por Titus Salt), Bournville (1879, por George Cadbury) e Port Sunlight (1888, por William Lever). "Esses empreendimentos possuem, como características comuns, localização junto ao campo e espaços abertos, com desenho informal privilegiando 0 verde e adaptando-se às características do terreno" (OTTONI, 1996, p. 25). Há ainda exemplos na França, Estados Unidos e até mesmo no Brasil. 
No mesmo período, alguns daqueles pensadores, teóricos e empresários, além dos próprios habitantes, passam a pressionar o poder público, exigindo a aprovação de leis que visem à melhor qualidade e higiene dos espaços construídos, fato que marca o início das diretrizes e leis para o planejamento urbano e reorganização regional de diversas cidades, tanto na Inglaterra quanto no restante da Europa e, a partir de então, disseminando-se pelo restante do globo.

Ainda no século XIX, as ideias de William Morris e John Ruskin, ligados ao movimento "Arts \& Crafts", muito influenciariam nas preocupações com a melhoria das cidades: a produção industrial terminava por promover aquilo que esses autores reputavam como uma baixa qualidade estética dos produtos, visto que a relação entre mestres e artesãos havia sido alterada, com a desvalorização do trabalho humano e do trabalho manual. Assim, o retorno àquilo que havia sido construído culturalmente como benesses de uma cidade anterior, localizada numa hipotética cidade medieval, de porte menor, ligada à natureza, ao campo, aos trabalhos artesanais, à ideia da casa como uma obra de arte (desenhada por arquitetos e realizada por artesãos experientes) era a proposta saída para a alienação provocada pela cidade industrial (UNWIN, 1984).

Influenciado por essas teorias e procurando melhores condições de vida para a população, Ebenezer Howard publica, em 1898, afastando-se do caos urbano industrial e suas mazelas, a primeira edição de sua obra, na qual propõe a ideia de cidade-jardim, intitulada To-Morrow: A Peaceful Path to Real Reform, reeditado em 1902 como Garden Cities of Tomorrow.

A proposta de Howard era um modelo de vida em que cidade e campo, urbano e rural, fossem integrados, com a população aproveitando os benefícios e qualidades de ambos, formando um terceiro (figura 1). Conhecida pela consagrada representação dos três ímãs de atração: cidade, campo e cidade-campo: a town-country, como foi denominada na edição de 1898 de sua obra e depois renomeada para garden city, a cidade-jardim, na reedição de 1902. 
Figura 1- Os três ímãs, apresentando cada modo de vida e suas vantagens.

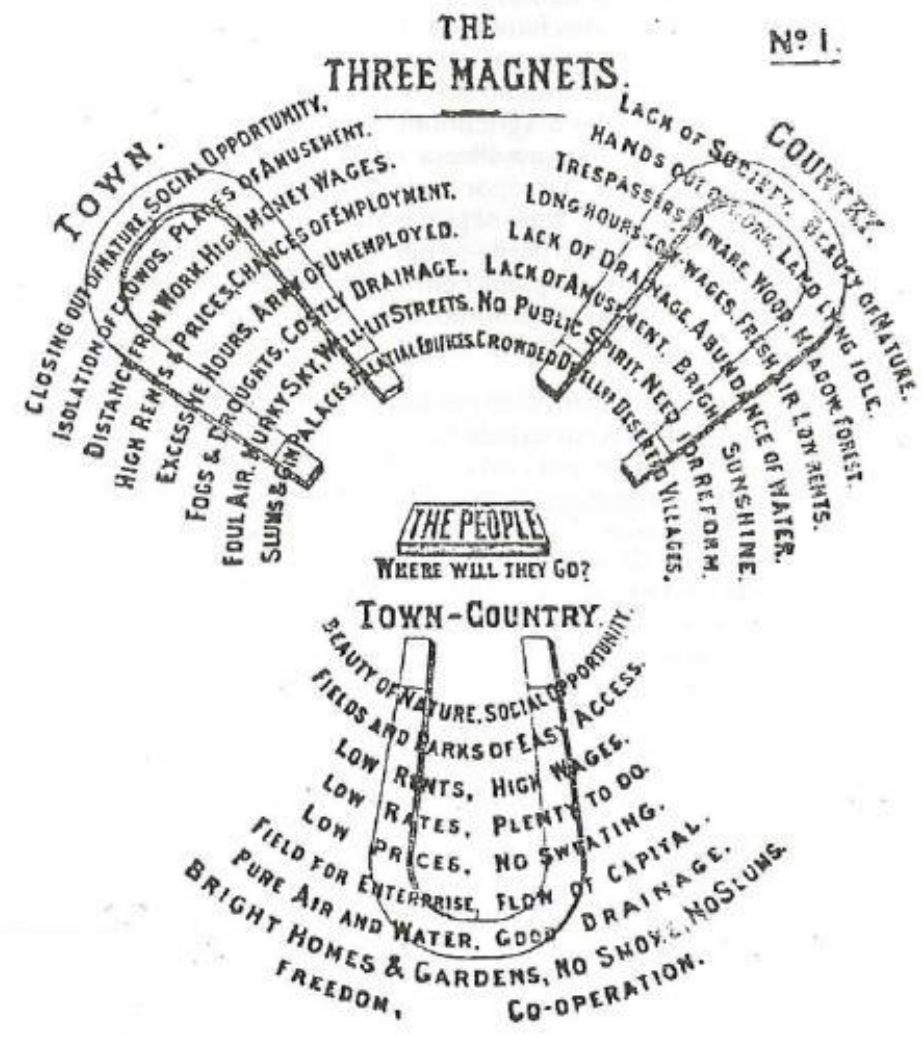

Fonte: Howard (1996), p.109.

Nas palavras de Howard:

Na verdade, não há somente duas alternativas, como se crê - vida urbana ou vida rural. Existe também uma terceira, que assegura a combinação perfeita de todas as vantagens da mais intensa e ativa vida urbana com toda a beleza e os prazeres do campo, na mais perfeita harmonia. (HOWARD, 1996, p.108).

Howard, que não era arquiteto, urbanista, construtor ou projetista, propôs então um modelo teórico, representado por diagramas de orientação, mas nunca chegou a propor um desenho urbano, ficando este a cargo de cada planejador e arquiteto, a partir do que encontrasse no local de implantação dos futuros projetos.

Seu modelo era formado a partir de uma terra agrícola, adquirida pela própria comunidade que viria a se instalar na área; o solo urbano criado seria, portanto, coletiva e não pertenceria a um loteador/especulador imobiliário. Assim, toda a renda obtida através das taxas, depois de pagas as parcelas de financiamento da terra, poderia ser reinvestida em benfeitorias para a própria cidade e sua população. Essa lógica partia de um governo central, municipal, selecionado e fiscalizado por ela. 
Howard procura provar que uma cidade-social, autossustentável, (self-maintenance), "envolvida por ambiente saudável de extenso verde, não é só realizável a custo convidativo, mas também socialmente desejável" (OTTONI, 1996, p.45).

A Cidade-Jardim seria construída no centro da propriedade adquirida e ocuparia uma área corresponde à sexta parte do total (de 2400 hectares, 400 ha seriam cidade); poderia apresentar forma circular e teria uma população de 30 mil habitantes na área "urbana" e dois mil no setor agrícola, que junto aos bosques e áreas verdes completariam os outros cinco sextos da propriedade.

O objetivo que aventuro-me agora a expor ante a população deste e dos demais países é nada mais, nada menos "nobre e adequado". Pretendo que ela possa entregar-se imediatamente à tarefa de edificar grupos de formosas cidades-lar, cada uma rodeada de jardins para aqueles que agora habitam cidades congestionadas e infestadas de cortiços (HOWARD, 1996, p. 178).

A partir de seu núcleo, no qual haveria um jardim de 2,2 ha e ao longo do qual estariam dispostos os edifícios públicos, haveria um parque público central de 56 ha, cortado por seis bulevares que, transversalmente à cidade, sairiam do núcleo e iriam até a circunferência, até o anel mais externo. Chegando à Grande Avenida, que forma mais um cinturão verde - green belt - com 4,8km de extensão, esta funcionaria como um parque de 46,5 ha. Apenas no anel mais externo é que se localizariam as fábricas, mercados, carvoarias, armazéns, bem com os hortifrutigranjeiros, próximos à área agrícola. Uma ferrovia envolveria toda a cidade, facilitando a entrada e saída de produtos e pessoas, e estaria conectada à linha principal, que cortaria a propriedade.

Quando a cidade-jardim atingisse sua população máxima, próxima a esta, a certa distância de sua zona rural, outra cidade seria construída, cada qual com sua municipalidade e um cinturão rural entre elas, formando uma rede de cidades com ligação direta à Cidade Central (figura 2). Por último, o agrupamento dessa rede de cidades sociais formaria uma área de 26700 hectares, uma região, com população de 250 mil habitantes, cada um com sua população de 32 mil habitantes e a Cidade Central com uma população de 58 mil habitantes (figura 2). 
Figura 2 - Diagramas: distritos e centro da cidade-jardim; diagrama de crescimento; formação da rede de crescimento das cidades.

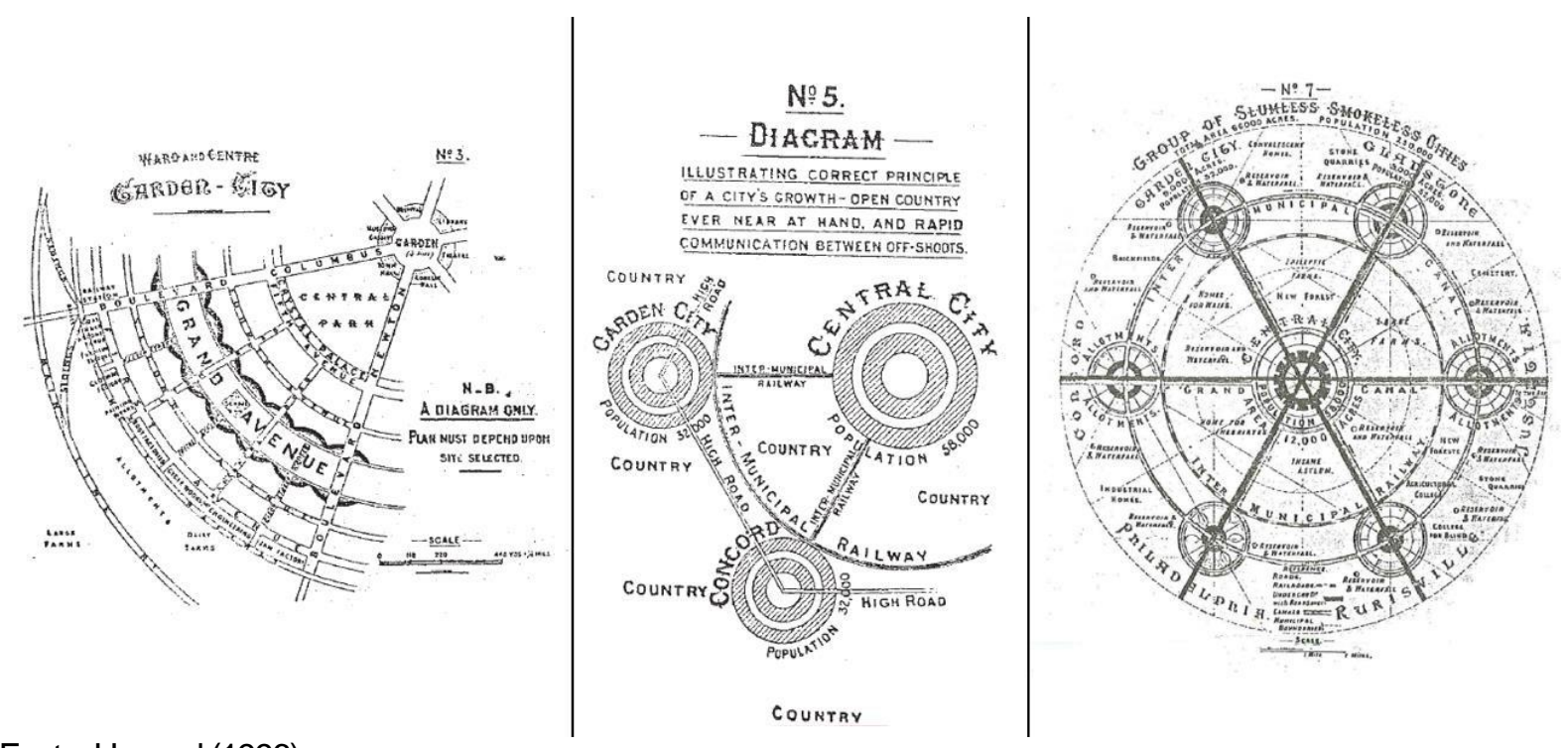

Fonte: Howard (1996).

Os espaços livres da cidade-jardim no plano de Howard eram marcados por seis bulevares com $36 \mathrm{~m}$ de largura que, irradiando a partir de um jardim central de 2,2 ha, em torno do qual está localizado também o Parque Central, com 56 ha, seguiam até o perímetro mais externo; além disso, no plano de avenidas concêntricas, a Grande Avenida se estenderia por 4,8km de extensão, além de possuir largura de $128 \mathrm{~m}$, totalizando um parque adicional de 46,5 ha. Neste plano proposto por Howard, descontando as áreas agrícolas e cinturões verdes externos ao perímetro urbano, a cidade-jardim contaria com um sistema de parques e áreas verdes de 104,7 ha, localizados a uma distância máxima de $220 \mathrm{~m}$ da residência de um remoto morador, no caso da Grande Avenida ou 558m no caso do Parque Central, no qual seria também instalado o Palácio de Cristal, que funcionaria como espaço comercial e jardim de inverno.

Considerando a arborização de grandes proporções, além dos jardins externos, calçadas, gramados, jardins internos das residências, a paisagem urbana da cidade-jardim manteria uma característica bucólica, com o campo permeando a cidade - influenciada pelo movimento Arts \& Crafts.

Além disso, os espaços livres e áreas verdes cumpririam seu papel de saneamento e ventilação dos espaços, permitindo a penetração da luz solar e ventos, 
o que não acontecia na cidade industrial superpovoada de condições urbanas precárias e vida miserável.

$\mathrm{Na}$ historiografia urbana, a proposta da Cidade-Jardim foi um dos modelos teóricos mais rápidos a se concretizar, tendo a cidade de Letchworth, na Inglaterra, sido fundada em 1903, intervalo curto de tempo entre teoria (lançamento do livro de Howard em 1898) e implantação. A compra do terreno, uma área inicial de 1546 hectares, foi realizada em 1902, a partir da fundação da "The Garden City Pioneer Company Ltd", a uma distância de $56 \mathrm{~km}$ de Londres.

Os responsáveis pelo projeto de implantação de Letchworth (figura 3) foram os arquitetos Raymond Unwin e Richard Barry Parker, que criaram um traçado simples; as ruas são abertas, bem como os espaços entre as residências, que formam blocos isolados, com recuos e jardins. As árvores, flores e arbustos e os parques abertos, com presença de vegetação original, acrescentam a aparência de campo à cidade e de convívio com a natureza. A ferrovia divide a propriedade em duas partes e a cidade é implantada sobre esse eixo, com a construção de uma estação central.

Figura 3 - Plano original de Letchworth Garden City, 1904.

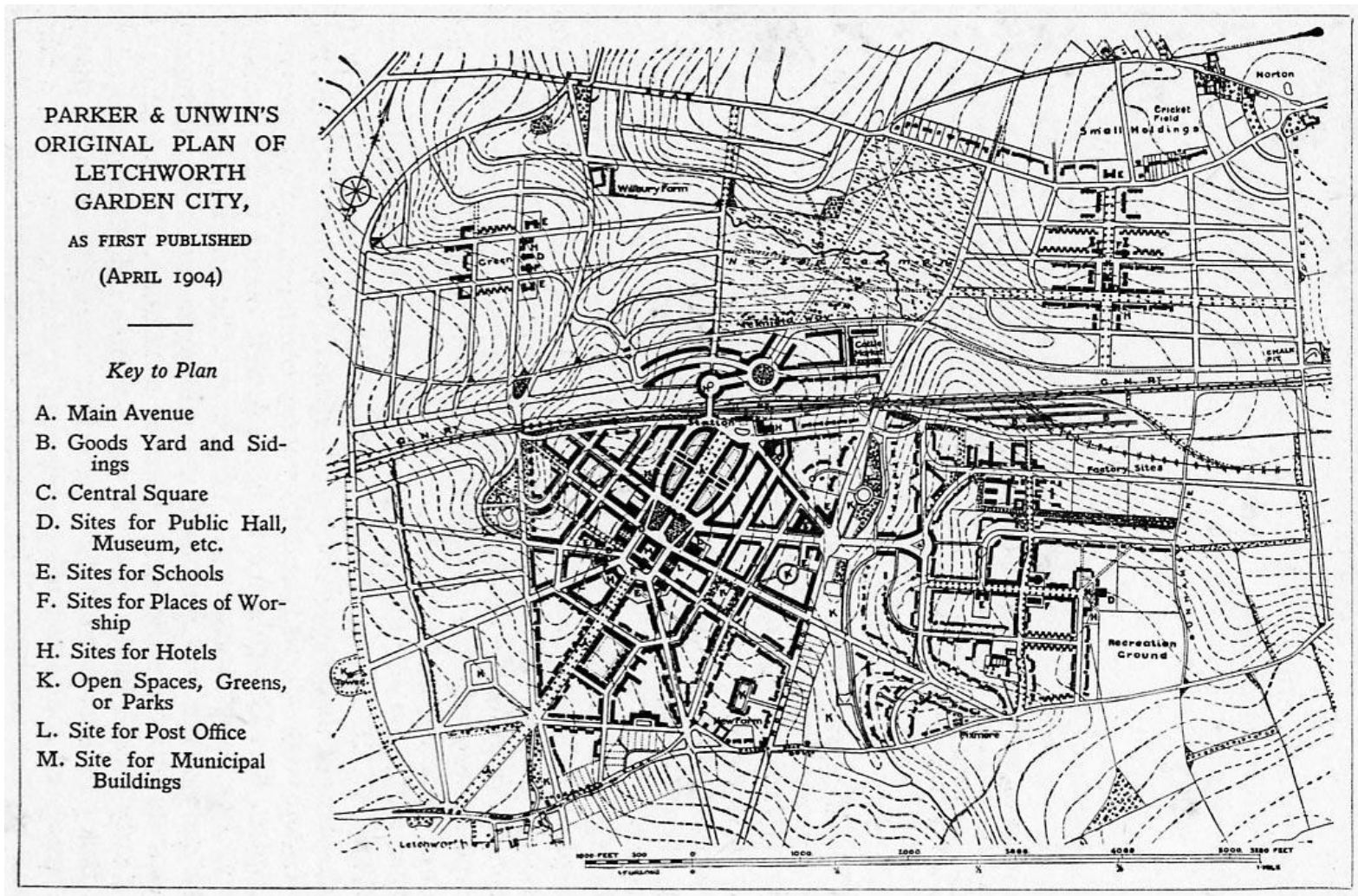

Fonte: Disponível em: http://reconomy.org/an-interview-with-julian-dobson-its-time-to-raise-a-glass-to-the-neweconomy/ 
A propriedade das terras urbanas e agrícolas por parte da municipalidade e 0 sistema de arrendamento permitem a continuidade do caráter coletivo da cidade, bem como de sua infraestrutura. Indústria e comércio instalam-se na cidade, mesmo que em passos lentos, mas cumprem sua função de promover empregos e acesso a bens de consumo e mercadorias.

Após a Primeira Guerra Mundial, em 1919, no período de reconstrução, Howard tenta implementar junto ao Governo um programa de construção de cidades baseados no modelo Cidade-Jardim, tornando-o uma política nacional. Desestimulado pelo governo, que procurava um plano de construção emergencial, com o maior número de casas em curto tempo, o grupo ligado a Howard decide por iniciativa própria construir outra cidade-jardim.

Welwyn, elaborada pelo arquiteto Louis de Soissons, foi desenvolvida em área rural a cerca de $15 \mathrm{~km}$ de Letchworth e marcada pela utilização da topografia do terreno na composição do traçado urbano: "ruas lineares junto à ferrovia, em terreno mais plano e encurvadas junto ao terreno mais inclinado, ajustando o desenho viário ao sítio urbano com sutil sensibilidade" (OTTONI, 1996, p.58). Trata-se de um desenho urbano em congruência com o meio físico.

A partir da teoria de Howard e o desenvolvimento de Letchworth, seu modelo de cidade-jardim servirá como base para outras propostas, desenvolvidas por Unwin e Parker em bairros e subúrbios, como é o caso de Hampstead Garden, um subúrbio de Londres, construído em 1907. Por considerar esse modelo uma fuga do projeto original, não representando a ideia de interação entre campo e cidade e muito menos gerando uma cidade-social, autossustentável, uma vez que o subúrbio-jardim nada mais é que um bairro periférico, não trazendo benefícios sociais à população, Howard rompe relações com Unwin.

Porém, a ideia de subúrbio-jardim e bairro-jardim se disseminaria pelo mundo, dando origens a bairros permeados pelo verde e traçado orgânico baseado nas linhas originais do relevo, muitas vezes ocupados pelas classes média e alta ${ }^{13}$.

As propostas e teorias da cidade-jardim, bem como de subúrbio-jardim, a partir dos trabalhos de Howard e Unwin, espalhar-se-iam rapidamente pelo mundo,

13 Com Clarence Stein, nos Estados Unidos, o modelo da Cidade-Jardim dará origem a diversos subúrbios; quando o modelo se alastrou pelo mundo, originou muitas vezes condomínios fechados, os enclaves fortificados (CALDEIRA, 2000), como são muitos dos casos encontrados nas cidades brasileiras. 
bem como pelo território brasileiro. Vitor da Silva Freire, Ulhôa Cintra, Saturnino de Brito, Prestes Maia, Luís Inácio Romeiro de Anhaia Melo são alguns dos profissionais que tem contato com o modelo e, de alguma forma, são influenciados por ele em seus novos projetos (BONFATO, 2008), com parques de várzea, parkways, green belt e até mesmo projetos para bairros inspirados no modelo cidade-jardim. Depois viriam Alfred Agache, no Rio de Janeiro, Atílio Corrêa Lima, em Goiânia, Jorge Macedo Vieira, em Águas de São Pedro, Maringá, entre tantos outros profissionais, bairros e cidades de atuação.

Porém, o destaque vai para a "City of São Paulo Improvements and Freehold Land Company LTD.", ou Companhia City como ficou conhecida, que elaborou, implantou e comercializou diversos projetos de bairros-jardins na cidade de São Paulo, disseminando o modelo. A Companhia, de capital inglês, acompanhando o mercado daquele país, que estava voltado aos lucros a partir de investimento externo e, aproveitando as possibilidades de crescimento de São Paulo, avaliadas por Joseph Bouvard, que aqui desembarcara em 1911 para colaborar com os planos de reestruturação do Anhangabaú, compra um total de 1200 hectares em terras, em 1912, valor que correspondia a $37 \%$ de todo o perímetro urbano de São Paulo (BONFATO, 2008).

Como base, a área do Jardim América é de 109 hectares, a qual foi loteada a partir de um projeto elaborado por Parker e Unwin; Parker chega ao Brasil em 1917 e desenvolve um projeto característico de um subúrbio-jardim, com ruas sinuosas, arborizadas e jardins internos às quadras - os quais viriam a ser loteados por falta de responsabilidade de manutenção já na década de 1930. A partir do enorme sucesso e com estoque de terras, a Companhia City urbaniza novos áreas, construindo os bairros do Pacaembu, Alto da Lapa, Alto de Pinheiros, Butantã e outros próximos ao Jardim América, além de realizar projetos para bairros e loteamentos em outras cidades no país.

Sobre a influência e disseminação no Brasil do modelo de Howard:

[...] falamos do bairro-jardim ou dos bairros-jardins, disseminados por todos os continentes e presentes na maioria das cidades brasileiras. $\mathrm{Na}$ realidade, observamos que trais produtos só guardam a tendência à rua sinuosa e a inserção da casa no centro do lote, o que lhes dá ares bucólicos, fugindo ao tradicional traçado monótono da quadrícula urbana. Por reunir tais características, os bairros-jardins se disseminaram entre as elites e se tornaram instrumentos poderosos de convencimento utilizados pelos especuladores imobiliários. Sua tradução mais funcionalista, no que se refere à especulação do uso da 
terra, é um produto que está do lado oposto ao que Howard apregoava: os condomínios fechados, "enclaves fortificados", onde o desenho sinuoso e até mesmo o excesso de áreas verdes foram devidamente triturados e direcionados à sociedade de consumo com alto poder aquisitivo. (BONFATO, 2008, p. 47)

\subsubsection{Espaços livres e planejamento com a paisagem: Frederick Law Olmsted}

Para Ester Higueras (2010), o sistema (figura 4) de espaços livres e áreas verdes compõem a espinha dorsal de qualquer projeto que vise à melhoria do bem-estar ambiental, sendo sua localização e quantificação os elementos que articulam toda a proposta de organização espacial para os usos recreativos e a localização de equipamentos.

Figura 4 - Ideia de um sistema: conexões entre os espaços livres - pequenos parques, grandes unidades de conservação, parques regionais.

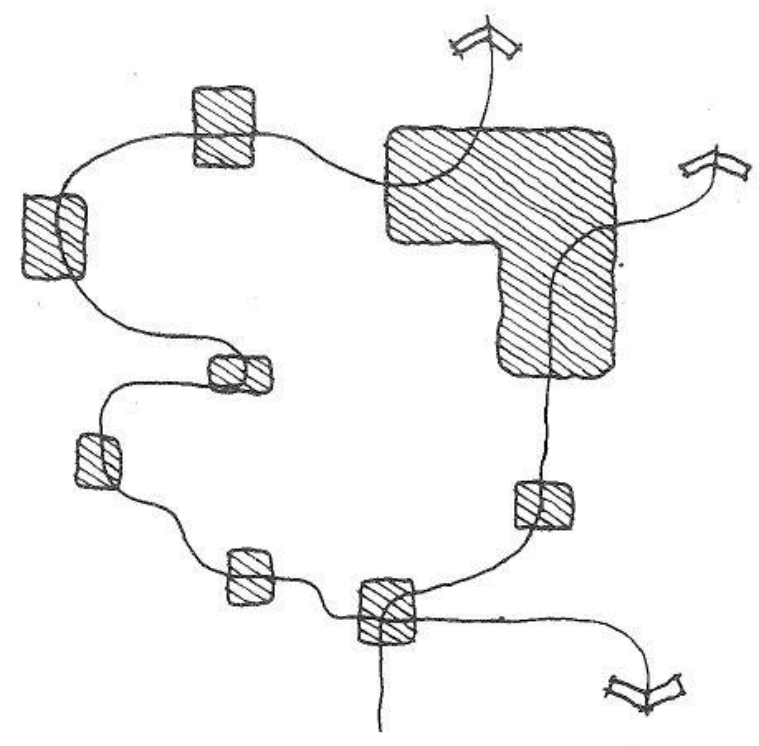

Fonte: HOUGH, 1998, p. 161

Miranda Magnoli (2006, p. 179) define: "o Espaço Livre é todo espaço não ocupado por um volume edificado (espaço-solo, espaço-água, espaço-luz ao redor das edificações a que as pessoas têm acesso)". Assim, o sistema de espaços livres (SEL) compreende todos os espaços livres de uma cidade, como ruas, rios, parques, jardins, quintais, praças, avenidas.... Sejam eles públicos ou privados.

$\mathrm{Na}$ cidade contemporânea o surgimento da estrutura básica dos espaços livres está diretamente vinculado às formas de propriedade, parcelamento do solo, possibilidades de renda e construção dos proprietários, tanto no caso de desmembramento de glebas com 
criação de novos trechos de malha viária, quanto no caso dos lotes por sobre os quais serão inseridas as construções. Os espaços livres são elementos estruturadores fundamentais, sendo responsáveis entre outros pelas condições básicas de circulação de veículos e pedestres, iluminação e aeração das construções. (CUSTÓDIO et al., 2013, p.02).

O espaço livre público, constituído em grande parte pelas ruas e calçadas, praças, parques, áreas livres, áreas de preservação, fundos de vale, forma um complexo sistema com o SEL, e interessa o estudo das suas particularidades e relações devido ao papel fundamental que desempenham na constituição da esfera de vida pública. Essa implicação tem raízes profundas no campo disciplinar da Arquitetura da Paisagem.

O espaço livre público representa, para a cidade, circulação, lazer, convívio, drenagem, proteção ambiental, conforto ambiental, conforto térmico, história, memória, cultura e significação; quanto mais dados e análises disponíveis, melhor a contribuição para o planejamento de novos espaços e para a reconfiguração dos preexistentes.

Portanto, o espaço livre é inerente à forma urbana; e inerente ao entendimento do processo de estruturação da cidade, que é baseada na produção do espaço por agentes públicos ou privados - e seus interesses próprios - com base em legislações específicas (MACEDO et al., 2012).

Pesquisando, já no século XX, e escrevendo sobre as relações entre cidade e natureza, espaços livres e também sobre a participação da natureza na paisagem urbana, Anne Spirn utiliza o caso de Boston, nos Estados Unidos, para exemplificar como as intervenções humanas na paisagem podem resultar em situações catastróficas para a cidade e sua população e também para relatar como um posterior processo de planejamento pautado pela valorização das características físico-naturais locais também pode reconverter a situação de conflito. A autora apresenta o projeto de paisagem realizado por Frederick Law Olmsted através de um planejamento sistêmico com os espaços livres para a cidade, e que o tornou reconhecido, somado a outros projetos, teorias e metodologia, como fundador do campo profissional da Arquitetura da Paisagem.

A cidade de Boston tem seu surgimento e desenvolvimento, ainda no século XVII, ligado a uma localização peninsular privilegiada, de fácil acesso, com fontes de água potável e extenso porto, o que levou a um grande crescimento populacional e 
econômico, que foi refletido na busca da ampliação do espaço físico, uma vez que, já no século XIX, a cidade apresentava restrições ambientais ao crescimento graças à presença de áreas alagáveis em boa parte de suas planícies.

Conforme relata Spirn (1995), para conseguir um aumento no território, colinas foram desmontadas e áreas das baías, pântanos e declives foram aterrados, alterando o formato inicial do território: "a linha da costa e a topografia de Boston foram mais alteradas pelas atividades humanas nos últimos 150 anos do que pelos processos naturais nos 10 mil anos anteriores" (SPIRN, 1995, p. 30-31).

O Século XIX apresentaria as modificações mais marcantes na paisagem da cidade, com o aterro da Back Bay e, nos anos seguintes, com a proposta para a construção de uma nova barragem, chamada de Mill, com a justificativa de geração de energia em maior quantidade. Porém, o sistema de drenagem da cidade, que era muito eficiente, dependia do fluxo das marés, que invadia as galerias na maré alta e, ao seu baixar, carregava consigo as águas servidas do sistema. A construção da nova barragem seria aprovada e sua construção concluída em 1821.

O novo sistema, entretanto, impedia a ação das marés, provocando uma mudança em seu curso e no fluxo dos rios da baía, levando a períodos de inundação nas partes mais baixas da cidade, além do acúmulo de esgoto, que muitas vezes era levado de volta pelo próprio sistema, devido às cheias provocadas pela nova barragem; como consequência: mau-cheiro, poluição das águas, diversas doenças.

A situação perdurou por cerca de cinquenta anos, até que, por volta de 1880, Frederick Law Olmsted projetou um parque - denominado Fens - desenvolvido em áreas criadas a partir da escavação da baía, e que serviria para o controle das enchentes e também para o controle do sistema de esgotamento sanitário. No local, o paisagismo contemplava espécies aptas a resistir às mudanças no nível das marés e com as diferentes características da água, uma mistura de águas doce e salgada.

O Fens foi projetado para armazenar temporariamente as águas das chuvas, sem provocar com isso a inundação das áreas adjacentes. Uma eclusa controlava o fluxo da maré para dentro e para fora do Fens, permitindo uma circulação regenerativa da água. Um novo sistema de canalização subterrâneo interceptava o esgoto vindo do córrego Stony e o desviava diretamente para o rio Charles. Desta forma, os baixios de maré da Back Bay transformaram-se num atrativo parque. (SPIRN, 1995, p. 38)

Frederick Law Olmsted foi responsável pelo desenvolvimento de um conjunto de vários parques para Boston, o Emerald Necklace, que tinha como base justamente 
o controle das enchentes e da qualidade da água e que acabou, por consequência, tornando-se em um espaço de recreação e lazer, permitindo o uso pela população em suas margens (SPIRN, 1995). Os parques criados por Olmsted em Boston, além de considerar a dinâmica dos processos naturais, conectavam as áreas centrais com outras mais distantes através de parques de diferentes escalas e bulevares, criando assim a ideia de um sistema (SCHENK, 2008). No caso do sistema de parques de Boston, ressalta-se que o projeto já se pautava na recuperação de uma paisagem totalmente alterada pelo homem.

O desmonte de morros e o aterro de áreas pantanosas resultaram não apenas na mudança de uma imagem que possibilitava a ampliação do território urbanizado, mas principalmente numa determinante alteração do fluxo das marés, que anteriormente contribuíam para esgotar e levar para o mar a água servida de bairros da cidade. (SCHENK, 2008, p. 121 e 122)

Frederick Law Olmsted é considerado pioneiro no campo da Arquitetura da Paisagem uma vez que sua trajetória de leitura, conceitos, pesquisa, experiências, trocas, encontros, projetos e ações compõem a base para a definição de um campo disciplinar e profissional que projeta os espaços livres para a cidade (SCHENK, 2008).

Olmsted, em uma viagem à Inglaterra em 1850, vivencia a situação de vida insalubre das massas populares e testemunha como os parques traziam significativa melhora à qualidade de vida no meio ambiente urbano, fazendo:

crescer a convicção de que esses espaços são necessários para civilizar a vida urbana; e mais, que a experiência artística passível de ser vivenciada nesses lugares só tem verdadeiro sentido se tornada pública; a beleza, repercutindo [John] Ruskin e seus outros profetas, não pode ser dissociada de sua utilidade social. (SCHENK, 2008, p. 99)

Além dos projetos para Boston, Olmsted desenvolve, juntamente com Calvert Vaux, o projeto para o Central Park, em Nova York, Estados Unidos - que viria a ser o vencedor dentre um concurso com outros 32 inscritos. No caso deste projeto, chama a atenção a criação de diversos cenários e paisagens - a partir do trabalho com 0 relevo e topografia, lagos, rochas e vegetação, criando percursos para pedestres, uma promenade para os passeios mais sociais e com expectativa de encontro, pistas de rolamento sem a quebra na continuidade da paisagem do parque, entre outros - em um local que não possuía belezas naturais notáveis. 
Segundo Schenk (2008), ao publicar Public Parks and the Enlargement of Towns, em 1870, Olmsted descreve o arranjo para a articulação dos sistemas de espaços livres nas cidades: parques, ruas - estas com um desenho de projeto diferenciado, mais apurado, que organizariam o tráfego e, uma vez que seriam arborizadas, além de permitir um caminhar agradável aos pedestres, funcionariam como conectoras desse sistema: as parkways - e avenidas. Ao longo de sua vida profissional, Olmsted desenvolve uma metodologia de projetar pensando os planos a partir de uma análise das características e dados locais, experiências e cenários possíveis, e que posteriormente viria a ser desenvolvida e aprimorada na leitura e proposições para as cidades que praticamos atualmente.

Assim, ao chegar ao planejamento para o sistema de parques em Boston, já em 1880, Olmsted trabalharia em uma escala que não mais seria a de um parque, mas a de um plano geral de desenvolvimento da região, articulando os espaços à cidade, sistematicamente. Ainda sobre o trabalho desenvolvido por Olmsted ao longo de sua vida e seu modo - pioneiro - de projetar, a autora afirma: "a preocupação com as lógicas próprias ao meio-ambiente urbano suscita a reflexão acerca da congruência entre projeto e lugar, sua natureza física e humana; associada a esta, o artifício que resulta numa paisagem" (SCHENK, 2008, p. 133).

Em vista disso, observa-se que paisagem é um conceito complexo, que vai muito além do natural e da estética, e envolve também processos sociais e sua relação com os aspectos físicos e ambientais; e que, por isso, encontra-se em constante - e acelerada, considerando o modo de vida do homem contemporâneo e sua produção e alteração do espaço - mudança.

\subsection{Paisagem e Arquitetura da Paisagem}

Para Milton Santos, paisagem é "a combinação de objetos naturais e de objetos fabricados, isto é, objetos sociais" (SANTOS, 1997, p. 37), compreendendo dois elementos: aqueles primeiros, que não são obra do homem, e estes, sociais, que são produto da ação do homem no território. Assim, sobre a paisagem transformada e construída pelo homem, que tem como um dos produtos fundamentais a cidade, Milton Santos relata:

Então, a cidade nos traz, através de sua materialidade, que é um dado fundamental da compreensão do espaço, essa presença dos tempos 
que se foram e que permanecem através das formas e objetos que são também representativos de técnicas. É nesse sentido que eu falei que a técnica é sinônimo de tempo: cada técnica representa um momento das possibilidades de realização humana e é por isso que as técnicas têm um papel tão importante na preocupação de interpretação histórica do espaço. Ora, essas técnicas que nos trazem as periodizações, que nos permitem reconstituir como aquele palimpsesto, que é a paisagem, a acumulação de tempos desiguais, que é a paisagem urbana, como ela chega até nós, permitem-nos também passar dos tempos justapostos aos tempos superpostos. Se considerarmos a história do espaço e do tempo ao longo da História, vamos ver que ela é o passar de momentos que se propuseram justapostos, isto é, em que cada sociedade que criava o seu tempo através de suas técnicas, através do seu espaço, através das relações sociais que elaborava, através da linguagem que conjuntamente criava também, a tempos que não são mais justapostos, tempos que são superpostos [...] (SANTOS, 2002, p. 21, grifo nosso).

Miranda Magnoli (2006) entende a paisagem como o objeto do paisagismo e não a ideia deste restrito somente aos estudos e projetos do "jardim": a paisagem seria o resultado das relações entre processos de ordem social e os processos naturais, adotando "uma perspectiva crítica, comum à geografia crítica, e já não aceita definir a paisagem simplesmente como a porção do território que a vista alcança a partir de um ponto privilegiado" (QUEIROGA, 2006, p.58). Para Magnoli, a paisagem é viva, qualificada e alterada por um sistema de ações que levam a diferentes estados da paisagem, fazendo-se necessário entendê-la em suas diferentes instâncias e dinâmicas.

Schenk (2008) descreve a paisagem como uma construção transversal e que contempla diferentes áreas do conhecimento, envolvendo-se, por isso mesmo, em diferentes percepções por profissionais de distintas áreas. Ainda segundo a autora, a definição de paisagem "carrega uma fixidez que só ganha movimento a partir da ideia do espaço" (SCHENK, 2008, p. 10), sendo este, portanto, o responsável por torná-la viva - o que nos faz relembrar Milton Santos e Miranda Magnoli, abordados acima - e possibilitar que seja construída por meio dos objetos e ações no decorrer dos tempos sobre este espaço.

Jean-Marc Besse, no livro de ensaios $O$ gosto do mundo: Exercícios de paisagem, também apresenta a complexidade do conceito de paisagem; polissêmico em sua definição, visto que diversas são as disciplinas e campos profissionais que tem a paisagem como objeto de estudo e trabalho. $O$ autor estabelece cinco possíveis 
leituras e abordagens, às quais nomina de "problemáticas paisagísticas", relacionando-as cada qual a um campo profissional:

Assim, a paisagem é considerada como uma representação cultural (principalmente informada pela pintura), como um território produzido pelas sociedades na sua história, como um complexo sistêmico articulando os elementos naturais e culturais numa totalidade objetiva, como um espaço de experiências sensíveis arredias às diversas formas possíveis de objetivação, e como, enfim, um local ou um contexto de projeto. (BESSE, 2014, p. 12)

A partir das descrições e análises por Besse (2014), de cada uma das problemáticas paisagísticas, podemos descrever ou citar alguns conceitos e ideiaschave:

a) "A paisagem fala-nos dos homens, dos seus olhares e dos seus valores, e não propriamente do mundo exterior" (BESSE, 2014, p.13); portanto analisar uma paisagem muitas vezes significa entender a expressão cultural de uma sociedade;

b) Apesar da gênese da paisagem estar ligada à pintura, ao enquadramento de cenários e às relações interior e exterior, a pintura é uma representação realizada a partir de uma interpretação do artista; é, portanto, uma construção social - e cultural, por consequência.

c) Paisagem é "um território produzido e praticado pelas sociedades humanas" (BESSE, 2014, p.27);

d) Ler a paisagem é visualizar uma organização espacial (BESSE, 2014, p.31) de uma sociedade em certa temporalidade ou em uma somatória de tempos;

e) A paisagem "é o elemento onde a humanidade se naturaliza e onde a natureza se humaniza (e se simboliza). E é o que invalida, no fundo, por princípio, qualquer abordagem unilateral da paisagem [...]: a paisagem deve ser definida mais rigorosamente, como meio ${ }^{14 "}$ (BESSE, 2014, p.42);

f) Paisagem é uma experiência: uma experiência fenomenológica;

g) "Caminhar é uma experimentação do mundo e dos seus valores. A caminhada, de fato, requalifica o espaço, no sentido próprio do termo: dando-lhe novas qualidades, novas intensidades" (BESSE, 2014, p. 55);

${ }^{14}$ (BERQUE, 1990 apud BESSE, 2014, p.42). Referência completa: BERQUE, A. Médiance. De milieux em paysages. Montpellier: GIP Reclus, 1990. 
Ao apresentar sua abordagem sobre a última chave - e que muito nos interessa pois trata da paisagem como projeto - o autor define o paisagista como um "operador da complexidade" (BESSE, 2014, p. 64). Transpassando por questões que vão desde a primeira porta, histórica, até a última, de projeto, o que aqui chamaremos arquiteto da paisagem reuniria as bases e questões dos diferentes campos e seria o responsável por transformar a paisagem - e planejar futuro e presente - a partir do que ele próprio compreende da mesma - em seu presente e passado -, e todas as suas relações.

Spirn (1995) e Besse (2014), mesmo abordando a paisagem por diferentes chaves, ou entradas - a primeira considerando as ações e processos de projeto realizados e o segundo destrinchando o conceito a partir dos seus vieses em cada campo profissional - ambos os autores têm em comum o fato de cidade e natureza não serem entes separados: a cidade é parte da natureza e a natureza está na cidade. Como escrevem, "a natureza já não significa mais apenas o "outro" da cidade, esta coisa verde mais ou menos selvagem que é encontrada no exterior do universo urbano" (BESSE, 2014, p. 58) uma vez que "ver a natureza na cidade é apenas uma questão de percepção" (SPIRN, 1995, p. 45).

Assim, caberia à arquitetura da paisagem reintroduzir essa percepção na cultura social: "educar o público através do lugar" (SCHENK, 2008, p. 121) - como afirmava Olmsted em seus escritos - criando a partir de "algo que já estava ali". (BESSE, 2014, p.61) - Essa tarefa cabe ao arquiteto da paisagem, uma vez que este projeta testemunhando e modificando, descrevendo e inventando, fazendo o inventário e construindo, desenhando (BESSE, 2014).

\subsection{Planejar com a paisagem: tempos recentes}

O planejamento com a paisagem é apresentado neste tópico com uma referência a "tempos recentes", desdobrando suas qualidades originais e atualizandose:

A arquitetura da paisagem, mesmo em terras americanas, não foi capaz de manter sua participação de forma decisiva no desenrolar do século XX. O urbanismo apresentar-se ia como a novidade técnica de gestão do fenômeno urbano, surgida também em meados do século XIX, quantificaria os problemas e registraria necessidades, 
substituindo os termos parques e jardins pelos espaços verdes (LE DANTEC apud SCHENK, 2008, p. 141)

Deste modo, constata-se acerca do planejamento com a paisagem em tempos recentes um retorno aos projetos de paisagem e uma continuidade de trabalhos com especial ênfase na dimensão ambiental. São pesquisas e projetos nesta área que não logrou ser a principal norteadora das ações de planejamento em um mundo Moderno - que priorizava a racionalidade funcional e para o qual as especificidades do lugar pouco, ou nada contavam (SCHENK, 2008, p.142).

O surgimento do Urbanismo e a necessidade de produzir uma matriz de ideias e pensamentos novos, que não tivessem a mesma referência dos trabalhos anteriores, levou a uma redução dos jardins e espaços livres a áreas verdes. O que era projetado e pensado a partir de uma noção espacial, foi-se condicionando para uma funcionalização, no qual o zoneamento ${ }^{15}$ - zoning - indicava áreas verdes para as cidades, mas não pensava no projeto do espaço e nas suas relações com o lugar.

Trabalhar com a paisagem de maneira sistêmica, através de um planejamento atualizado pela ecologia tem, em meados do século $\mathrm{XX}$, um retorno após longo período de perda de visibilidade enquanto prerrogativa que pudesse nortear ações de produção de Planos e Projetos. A partir dos trabalhos e pesquisas de lan McHarg que publica Design with Nature em 1969 - e, posteriormente, também com Anne Spirn - e a publicação da obra O Jardim de Granito, em 1984 - e Michael Hough - com Cities and Natural Process, em 1994.

McHarg, considerado o primeiro planejador ecológico, entende a natureza como processo, portanto mutável com e pelo ambiente e suas lógicas; assim, pensar sistematicamente é parte de um processo que envolve o meio físico (natureza), o meio construído (cidade) e as relações desenvolvidas entre eles na ocupação do território. Assim, "concluímos que a natureza é um sistema único de interação e que alterações em qualquer parte afetarão a operação do todo"16 (MCHARG, 1992, tradução nossa). McHarg é considerado pioneiro na autoria de uma estratégia metodológica que utiliza o cruzamento de informações para um planejamento sistêmico da paisagem.

\footnotetext{
15 Conforme relata Feldman (2005), o zoneamento se transforma, com o passar dos anos, no principal "instrumento" de planejamento urbano, quando este passar a ser institucionalizado.

${ }_{16}$ We conclude that nature is a single interacting system and that changes to any part will affect the operation of the whole (MCHARG, 1992, p. 56)
} 
O autor descreve exemplos de ocupação nos quais evidencia que o conhecimento dos processos naturais sobre o território, das ações humanas e interações, leva a situações nas quais se consegue antever ou lidar de melhor forma com as adversidades apresentadas pela natureza - tempestades, enchentes, movimentação de placas geológicas, por exemplo - ou criadas pelo homem - conflito meio físico versus ocupação humana. Desse modo, segundo o autor, "talvez a abordagem mais razoável seja investigar a tolerância ou intolerância dos vários ambientes ao uso humano em geral e a alguns usos particulares"17 (MCHARG, 1969, p. 13) e reconhecer as limitações e até mesmo proibições para certos usos.

Em seu livro, McHarg deixa clara a necessidade de preservação e cuidado com a natureza, principalmente àquela que permeia o urbano - portanto, não é uma questão de escolha entre cidade e campo -, à qual convoca como preciosa, por sua escassez em tempos atuais, nos quais as cidades "crescem, se fundindo em um colar continental de megalópoles, tecido cinza morto que circunda a nação"18 (MCHARG, 1969, p. 23).

Seus estudos e ações de projeto evidenciam trabalhos realizados em diferentes escalas, da local à regional, em um processo de planejamento no qual trabalha com o cruzamento de informações (MCHARG, 1969), previamente dispostas em camadas (layers), nas quais analisa individualmente aspectos como clima, recursos hídricos, vegetação, altimetria, vida selvagem, geomorfologia, geotécnico, pedologia e urbanização, dispostos em transparências que pudessem ser sobrepostas, para posteriormente projetar com a paisagem a partir do cruzamento destas informações.

Como parte do processo, McHarg mesclava ainda paisagem natural e paisagem cultural, identificando nos levantamentos mapas de lugares cênicos, lugares de interesse histórico, vistas interessantes, monumentos, entre outros. Ao fim, a síntese do processo de leitura da paisagem se dava através de um "mapa de aptidões" (suitability map).

\footnotetext{
${ }_{17}$ Perhaps the most reasonable approach would be to investigate the tolerance or intolerance of the various environments to human use in general and to some particular uses (MCHARG, 1969, p. 13).

${ }_{18}$ And so out cities grow, coalescing into a continental necklace of megalopolis, dead gray tissue encircling the nation. (MCHARG, 1969, p. 23)
} 
Assim, essa metodologia desenvolvida identificava a melhor ocupação para um espaço ou possíveis tipos de uso, considerando as melhores áreas e as mais vulneráveis para cada fim.

Ao propor seu método para identificar o melhor traçado para uma rodovia - a Richmond Parkway -, por exemplo, McHarg discute a frequente redução das problemáticas para as variáveis tráfego, volume, velocidade, capacidade, estrutura, pavimentação, quando o que deveria ser considerado, na verdade, deveria ser o provimento do "máximo benefício social ao mínimo custo social"19 (MCHARG, 1969, p. 32). Segundo o autor, para isso seria necessário "apenas abandonar o modelo econômico e a insensível indiferença do homem antropocêntrico"20 (MCHARG, 1969, p. 31) e passar a considerar a avaliação dos processos naturais e sociais. E na relação destes com a construção de Paisagens.

No processo, foram elaboradas três categorias de análise (MCHARG, 1969): a primeira, envolvendo critérios físicos e geológicos - declividade, geologia da rocha, condições de fundação do solo, drenagem do solo e suscetibilidade à erosão; uma segunda categoria, que aborda os perigos relacionados às propriedades e à vida, e incluiu as áreas vulneráveis à inundações causadas por furacões; por fim, em uma última etapa, foram analisados os processos sociais e naturais - valores históricos, da água, das florestas, de vida selvagem, cênicos, recreação, residenciais, institucionais e valores da terra.

Dispostos em transparências, as categorias, cartografadas, eram sobrepostas até a obtenção de um mapa resumo, no qual o tom mais escuro representava as maiores valorações - portanto menos recomendável para o traçado - e os tons mais claros apresentavam os menores valores - e, com eles, as áreas de menores custos para as categorias analisadas -, sendo, portanto, recomendáveis para a construção da via. O estudo e análises desenvolvidos foram aceitos pela comissão de transportes responsável pela rodovia e o traçado proposto foi revisto, em acordo com as indicações realizadas pelo estudo.

Do exemplo anterior, que poderíamos considerar como uma ação de projeto de caráter mais local, McHarg fez análises e foi convocado para diversos outros

\footnotetext{
19 The best route is the one that provides the maximum social benefit at the least social cost (MCHARG, 1969, p. 32)

${ }^{20}$ Is is necessary only to abandon the economic model and the calloused indifference of anthropocentric man. (MCHARG, 1969, p. 31)
} 
estudos e proposições, mais abrangentes, como um sistema de espaços livres - ou sistema de espaços abertos, como nomeia em seu livro - na região metropolitana de Filadélfia (EUA) e também um plano para aplicação de seu método de planejamento para o The Valleys, região metropolitana de Baltimore (EUA).

Para o primeiro, um sistema de espaços livres, McHarg propunha que os espaços abertos e verdejados, compreendidos fundamentalmente como aqueles que não tem construções, fossem distribuídos pelo território, estando a um maior e mais fácil alcance da população - "Buscamos um conceito que possa fornecer uma fusão entre espaço aberto e população"21 (MCHARG, 1969, p. 65). McHarg também almejava que as áreas ambientais fossem protegidas e identificadas pelo poder público, garantindo sua existência e permanência futura. Oito variáveis - águas superficiais, pântanos, várzeas, áreas de recarga de aquíferos, aquíferos, encostas íngremes, florestas, bosques, terras planas - referentes aos processos naturais foram analisadas e, a partir de então, foram definidas permissões ou proibições de uso do solo para, ao final da análise, identificar o "lugar da natureza" na metrópole 22 (MCHARG, 1969).

Para o caso do The Valleys, uma região em crescimento no subúrbio de Baltimore (EUA), cabe ressaltar que McHarg propõe um desenvolvimento equilibrado - "preparando um plano para garantir a preservação do mais alto nível de amenidade com ótimo desenvolvimento"23 (MCHARG, 1969, p. 79) - para a região, testando os princípios do planejamento ecológico em contraponto ao usual crescimento da metrópole baseada nos moldes do mercado imobiliário e de capital, que pressiona, neste caso, a urbanização da região pela valorização do seu potencial em virtude da abertura de novas estradas na área.

McHarg propõe, então, através de "princípios fisiográficos" para desenvolvimento e conservação, a manutenção e valorização de cenários, proibição de usos e de desenvolvimento em certas regiões - tais como várzeas e aquíferos -, manutenção do traçado e curso natural dos rios - além do indicativo de áreas de preservação lindeiras a estes cursos d'água - entre outras ações. Propõe também o

21 The problem lies not in absolute area but in distribution. We seek a concept that can provide an interfusion of open space and population. (MCHARG, 1969, p. 65)

22 However, eight natural process have been identified and these have been mapped and measured. Each one has been described with an eye to permissiveness and prohibition to certain land uses. It is from this analysis that the place of nature in the metropolis will be derived (MCHARG,1969, p. 57)

${ }^{23}$ Preparing a plan to ensure preservation of the highest level of amenity with optimum development. (MCHARG, 1969, p. 79) 
"corte fisiográfico" (figura 5) - que distingue especial tipo de corte, caracterizado não somente pela representação da geografia física, mas também a paisagem local - pelo qual a leitura da região e as proposições de cenários (figura 6) de crescimento e ocupação pudessem ser melhor entendidos e visualizados.

Figura 5 - Corte Fisiográfico: estudo para a região do The Valleys.

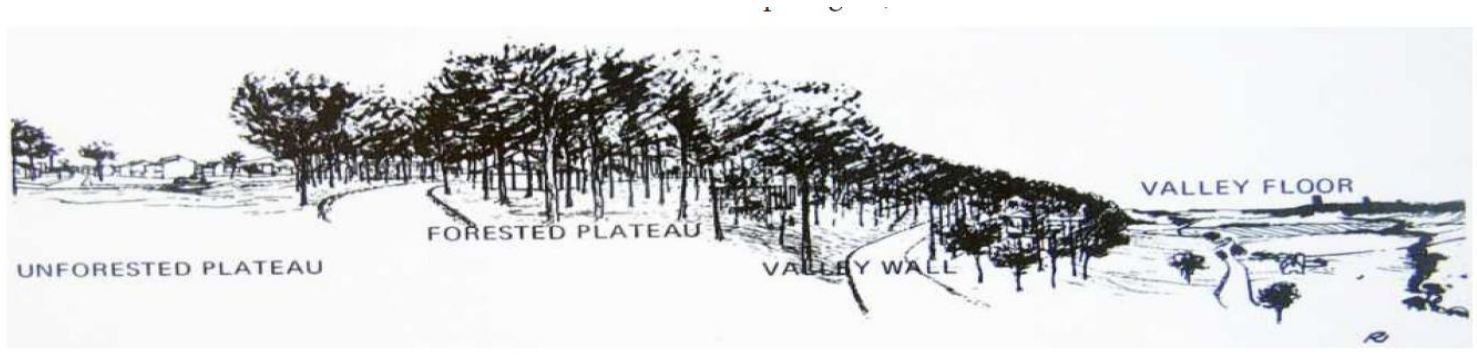

Fonte: McHarg (1969, p. 87).

Trabalhando com diferentes relações, dados e cenários em um sistema, lan McHarg chegou a processos de planejamento em escala regional, em áreas definidas pelos próprios processos naturais, como foi o caso do estudo para a bacia do rio Potomac, que teve como unidade de planejamento a bacia hidrográfica; este estudo será abordado no tópico conseguinte. 
Figura 6 - Estudo de cenários possíveis para o projeto do The Valleys.
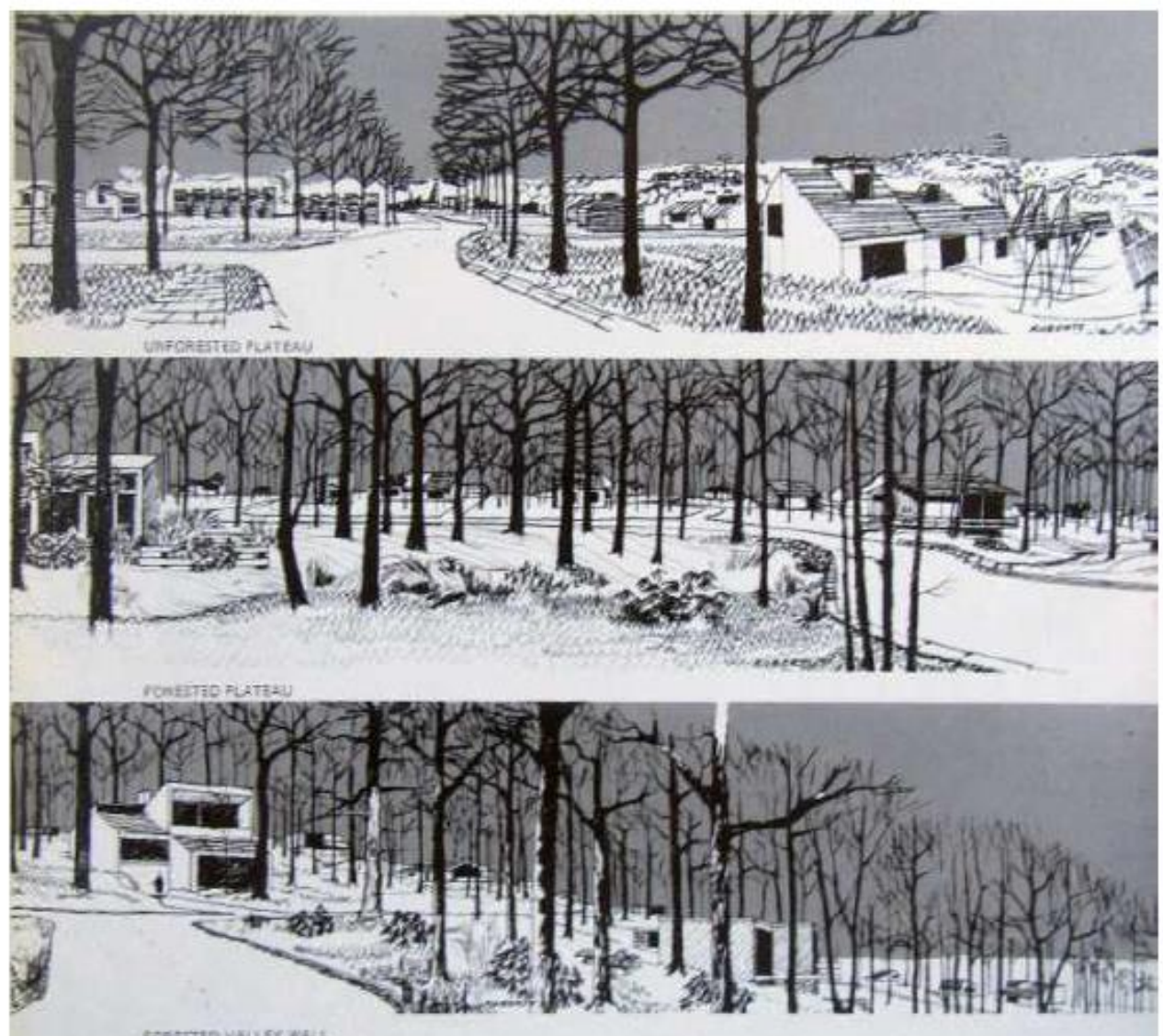

Fonte: McHarg (1969, p. 90).

Com relação a autores, projetos e trabalhos com a paisagem, seguindo os pensamentos e ideias de McHarg, Anne Spirn e Michael Hough também afirmam em seus trabalhos que a natureza comporia uma totalidade e, portanto, a cidade seria parte da natureza.

Em O Jardim de Granito, presente no início deste capítulo, Anne Spirn tenta desfazer o conflito que coloca cidade e natureza como dimensões separadas e não a primeira como parte desta segunda. Relata ser necessário a compreensão de que os mesmos processos que ocorrem na floresta ocorrem também na cidade, uma vez que essa visão de que são entes separados afetou e continua dominando o modo como a cidade é construída, agravando muitos dos problemas ambientais urbanos, que se refletem no todo, na natureza em geral, já que esta "é ubíqua, um todo que envolve a cidade" (SPIRN, 1995, p. 21).

Michael Hough, arquiteto paisagista canadense, também propõe uma visão ecológica de planejamento, na qual natureza e usos humanos sejam compatíveis e vistos como interdependentes, uma vez que é impossível dissociar o meio ambiente 
construído do meio ambiente natural na realidade em que vivemos, após tantas transformações promovidas pela vida humana.

[...]um retorno a um estado "puramente natural" com absoluta ausência de presença humana é impossível; o importante é que, na criação de novas paisagens - uma mistura de natural e humano que talvez não existisse antes - seja reconhecida a interdependência do homem e da natureza nas realidades ecológicas, econômicas e sociais da cidade ${ }^{24}$. (HOUGH, 1998, p. 29)

Em seu livro Cities and Natural Process, o autor propõe "encontrar uma alternativa ao tratamento tradicional da paisagem urbana que esteja em sintonia com uma crescente consciência ambiental das cidades e da natureza" ${ }^{25}$ (HOUGH, 1998, introdução). Para isso, incorpora os princípios biológicos no planejamento, propondo a renovação das cidades através da ecologia urbana, assunto tratado no primeiro capítulo; nos capítulos sequenciais, aborda separadamente os tópicos relacionados à natureza - água, plantas, fauna, agricultura urbana, clima - e seu impacto no processo de desenho e de planejamento.

A partir de uma base teórica e histórica, o autor evidencia a possibilidade de mudanças na vida urbana evidenciando projetos e processos de planejamento com a paisagem que foram concretizados e que invertem 0 viés majoritariamente 0 protagonismo econômico encontrado nos processos de urbanização e crescimento das cidades - em detrimento aos processos meio-ambientais e sociais (HOUGH, 1998).

Ao comentar a paisagem urbana encontrada nas cidades, Hough (1998) descreve o quão monótono é o desenho dos espaços qualificados através de projetos na cidade atual, bem como a falta de diversidade de espécies - vegetais, e consequentemente animais - que apresentam. Pontua a necessidade da diversidade nas cidades, entendendo que quanto mais diversa, mais instigante e estimulante se torna o ambiente. Segundo o autor, há falta de conexão e conhecimento em relação à dinâmica dos processos naturais (HOUGH, 1998).

A integração do planejamento urbano e da ecologia, alcançada através dos processos de design e planejamento, é o que nos

24 "[...] un retorno a un estado "puramente natural" con ausencia absoluta de la presencia humana es imposible; lo importante es que en la creación de nuevos paisajes - una mezcla de los naturales y humanos que pueden no haber existido antes - se reconozcan la interdependencia del hombre y la naturaleza en las realidades ecológicas, económicas y sociales de la ciudad". (HOUGH, 1998, p. 29)

25 "Es urgente encontrar una alternativa al tratamiento tradicional del paisaje urbana que esté en sintonía con una creciente conciencia medioambiental sobre las ciudades y la naturaleza." (HOUGH, 1998, p. 1) 
preocupa aqui. Isso estabelece laços entre uma visão local e uma visão bio-regional mais ampla e faz conexões entre elementos díspares, revelando possibilidades que de outra forma não seriam aparentes. A visão proporcionada pela ecologia urbana, quando agregada aos objetivos sociais e econômicos, cria uma base racional para moldar a paisagem da cidade. ${ }^{26}(\mathrm{HOUGH}, 1998$, p. 16).

E esta problemática se aplica não somente às questões de diversidade ecológica, mas também de drenagem das águas pluviais, de tratamento e condução das águas residuais, por exemplo: o modo a que nos foi ensinado, de ver a natureza como um ente separado da cidade, nos fez projetar e reproduzir mecanismos que devem retirar, da maneira mais rápida e funcional, as águas pluviais e residuais da cidade e levá-las para um local distante, fora dos centros ou para longe destes, no campo. Como se as dinâmicas da primeira não interferissem no segundo, e vice-versa. Hough destaca também o princípio da educação ambiental como base para o entendimento das problemáticas e conexões do meio ambiente: começando em casa, no próprio ambiente familiar, a educação ambiental pode levar ao entendimento e conexões com as problemáticas regionais e internacionais.

Continuando em um tópico educação, mas por outra abordagem - a educação pelo lugar e pelo olhar - o arquiteto paisagista propõe que "se façam visíveis os processos que sustentam a vida" 27 (HOUGH, 1998, p. 28, grifo nosso) e que este princípio esteja presente também nos projetos e planejamento, uma vez que "o design que oculta os processos naturais leva ao empobrecimento sensorial"28 (HOUGH, 1998, p. 28).

Em uma perspectiva que vai além do projeto como desenho de arquitetura e urbanismo, Michael Hough propõe um planejamento com a paisagem que é ambiental, social, cultural, econômico, energético, educacional; como é nomeado pelo próprio autor no primeiro capítulo do livro Naturaleza y Ciudad, esta ecologia urbana seria a base para a remodelação das cidades (HOUGH, 1998).

Os princípios baseados na ecologia urbana e aplicados às oportunidades oferecidas pela cidade por meio de recursos próprios

26 "La integración del urbanismo y de la ecología, conseguida a través de los procesos de diseño y planificación, es lo que nos preocupa aqui. Esto estabelece lazos entre una visión local y una visión bio-regional más amplia, y realiza conexiones entre elementos dispares, revelando unas posibilidades de que otra forma no resultarían evidentes. La visión que proporciona la ecología urbana, cuando se añade a los objetivos sociales y económicos, crea una base racional con la que conformar el paisaje de la ciudad." (HOUGH, 1998, p.16)

27 "Hacer visibles los procesos que sostienen la vida" (HOUGH, 1998, p. 28)

28 "El diseño que oculta los procesos naturales lleva a un empobrecimiento sensorial" (HOUGH, 1998, p. 28) 
formam a base para uma linguagem alternativa no design. Esses princípios incluem os conceitos de processo e mudança, a economia de meios que obtém o máximo benefício do mínimo esforço e energia, a diversidade como base da saúde ambiental e social, as conexões que reconhecem a interdependência da vida humana e não-humana, tornar visíveis os processos que sustentam a vida, uma educação ambiental que começa em casa e leva em conta problemas ecológicos em todo o mundo e uma meta que enfatiza a importância dos valores ambientais ligados à mudança, uma integração do ser humano com processos naturais em um nível essencial. ${ }^{29}$ (HOUGH, 1998, p. 31)

Ao relacionar seus princípios com os processos de planejamento, Hough (1998) apresenta múltiplos casos de projetos relacionados às diferentes temáticas que compõe a ecologia urbana:

a) Mostra casos de naturalização de parques - afirmando uma vez mais que o formalismo dos projetos causa monotonia estética e ecológica nestes espaços e que é necessário promover sempre a diversidade de espécies vegetais, animais e diversidade social e a conexão destas com os processos naturais e físicos -;

b) Restauro e regeneração de fauna nos parques e espaços livres urbanos;

c) Incentiva a agricultura urbana - mostrando, por exemplo, que espaços sob as linhas de eletricidade ou as intersecções rodoviárias poderiam ser utilizados para agricultura e que estas ações comporiam novas possibilidades de paisagem e projeto em espaços residuais -;

d) Apresenta a problemática do clima urbano e das alterações climáticas provenientes pelas formas e usos urbanos - explorando novas opções de desenho e projeto capazes de colaborar na produção de microclimas, como pátios sombreados, presença de água, jardins verticais em muros e paredes de edifícios, espaços exclusivos para pedestres;

\footnotetext{
29 "Los principios basados en la ecología urbana y aplicados a las oportunidades que proporciona la ciudad a través de sus propios recursos, forman la base para un lenguaje alternativo en el diseño. Estos principios incluyen los conceptos de proceso y cambio, la economía de medios que obtiene el máximo beneficio a partir del mínimo esfuerzo y energía, la diversidad como la base para la salud medioambiental y social, las conexiones que reconocen la interdependencia de la vida humana y no humana, hacer visibles los procesos que sustentan la vida, una educación medioambiental que comience en el hogar y tenga en cuenta los problemas ecológicos en todo el mundo, y una meta que acentúe la importancia de los valores medioambientales conectados con el cambio, una integración del ser humano con los procesos naturales en un nivel esencial." (HOUGH, 1998, p. 31)
} 
Contudo, é ao abordar o tópico água e os efeitos da urbanização sobre o ciclo hidrológico e sobre as águas urbanas que Michael Hough nos traz um exemplo paradigmático de uma restauração para toda uma bacia hidrográfica - a do Rio Don, situado na Grande Toronto, Canadá - em um processo de planejamento que procurou não apenas recuperar a dimensão ambiental física, mas contribuir no processo de ressignificação do rio e seu entorno para a população. Por trabalhar com toda a bacia, o processo de requalificação exigiu a análise de diversos parâmetros e questões, incluindo uma caracterização histórica que descreve acontecimentos presentes em grande parte dos rios em meio urbano: rios são vistos como entrave ao crescimento, são canalizados, poluídos, tem suas margens transformadas em corredores de transporte e, com o tempo, tornam-se invisíveis à população. Por suas questões de planejamento envolvendo uma bacia hidrográfica, e por estar relacionado a processos presentes na cidade analisada neste trabalho, abordaremos este projeto e suas especificidades em tópico posterior.

Enfim, observa-se que as mudanças ocorridas a partir dos anos 1960, com a reconsideração da natureza como parte do meio construído, foi um reencontro com processos já realizados ainda no século XIX. Em 1972, a Conferência da ONU sobre o Meio Ambiente, realizada em Estocolmo, foi "o primeiro grande evento a analisar e avaliar a temática ambiental de um ponto de vista que preconizava a necessidade de proteção dos recursos naturais para o bem-estar da sociedade" (GORSKI, 2010, p. 95).

Chega-se, nas décadas finais do século XX, portanto, com a certeza de que não é mais interessante, viável e possível - se pensarmos na continuidade e manutenção da vida em meio urbano - para as cidades se estruturarem através de obras rodoviárias, canalização e tamponamento de córregos, galerias de drenagem, impermeabilização do solo, supressão de vegetação e tantas outras soluções da chamada engenharia cinza. Do mesmo modo, não se pode mais, tendo em vista a agenda contemporânea ambiental considerar a natureza como dissociada das cidades: já vimos que são interdependentes e que as ações realizadas nas cidades interferem no campo, assim como o contrário também é válido. Um número cada vez maior de pesquisadores analisa os processos históricos e propõe a valorização do meio ambiente natural e sociocultural nos processos de projeto e de planejamento urbano e paisagem. 
Projetos realizados e estudos evidenciam a natureza presente na cidade e também buscam soluções de projeto baseadas nesse processo de planejamento ecológico, identificando os processos naturais, ecossistêmicos e sociais que ocorrem nas cidades e tentando rever conceitos e ideologias de planejamento do início e meio do século XX que não se "encaixam" na realidade atual. Desenvolvem-se também um número cada vez maior de projetos de baixo impacto, mas eficientes, sob um viés sustentável e que viria a ser referenciado como infraestrutura verde.

Estas técnicas - que consideram sobretudo um planejamento da paisagem e das cidades a partir da identificação de seus processos naturais e relações com 0 meio ambiente construído ao longo dos tempos - representam importantes pautas para o tema deste trabalho e serão abordados nos tópicos seguintes: o planejamento a partir das bacias hidrográficas e o conceito de infraestrutura verde.

\subsubsection{Planejamento a partir de uma unidade de paisagem: bacia hidrográfica}

Mais do que qualquer outro elemento além das árvores e dos jardins, [a água] tem o potencial de forjar um elo emocional entre o homem e a natureza na cidade. (SPIRN, 1995, p.159)

Conforme os assuntos tratados, entendemos que os rios foram parte do processo de surgimento de diversas cidades e estiveram presentes na paisagem e imaginário urbano da população.

Os rios tinham muito a oferecer, além de água: controle do território, alimentos, possibilidade de circulação de pessoas e bens, energia hidráulica, lazer, entre tantos outros. E desta forma, as paisagens fluviais foram paulatinamente se transformando em paisagens urbanas (COSTA, 2006, p.10).

Vimos também que processos de planejamento em vigor, sobretudo no século passado, levaram à descaracterização de muitos fundos de vale, incluindo os rios e suas margens, tendo como conclusão o encapsulamento de diversos destes cursos d'água - seja por sua canalização ou completa invisibilização pelo tamponamento - e sua transformação em vias de transporte. De significado análogo em termos de geração de invisibilidade é o abandono desses espaços, uma vez que a falta de manutenção de suas margens e a poluição geram na população uma percepção negativa. Isso, associado à ideia de que o corpo de água opera como limite, um 
entrave ao crescimento das cidades originou um processo de planejamento e ocupação dos vales que "dá as costas aos rios".

Excetuando-se os maiores, todos os córregos e cursos d'água da paisagem anterior à urbanização desapareceram dos mapas modernos. Cobertos e esquecidos, antigos cursos d'água ainda correm através da cidade, enterrados sob o solo em grandes tubulações, canais primários de um sistema de drenagem subterrâneo. Seu ruído abafado pode ser ouvido sob as ruas após uma chuva pesada; eles são invisíveis, mas sua contribuição potencial às enchentes a jusante não é, todavia, diminuída, mas sim aumentada (SPIRN, 1995, p. 146)

Este subitem do trabalho traz exemplos de metodologia e projetos concretizados que procuraram ressignificar os rios - buscando abordar um processo de reencontro (GORSKI, 2010) entre meio urbano, cursos d'água e processo de planejamento - projetando a paisagem de maneira ecossistêmica, a partir de suas bacias hidrográficas.

A escolha da bacia hidrográfica como base de trabalho não é aleatória; elas representam um sistema completo e complexo. Bacias hidrográficas são uma área de drenagem comum - limitada pelos divisores de água, que são os pontos mais altos do relevo - à qual uma séria de cursos d'água convergem para um rio de maior calibre, que geralmente nomeia a Bacia (GORSKI, 2010) e por isso possuem conflitos e processos - naturais, ecológicos, sociais - que mesmo pontuais podem afetar o sistema - bacia - como um todo e tudo que a ela estiver relacionado, como por exemplo, a dinâmica das cidades.

No Brasil, o planejamento público com base nas bacias hidrográficas, posto em prática nos de 1960 viria a se enfraquecer e só retornaria no fim do século XX, quando, em 1997, através da Lei federal no 9433/97, a bacia hidrográfica seria tida como a unidade de intervenção no modelo de gestão dos recursos hídricos; no estado de São Paulo, porém, desde 1991, com a Lei no 7633/91, se estabeleceu a Política Estadual de Recursos Hídricos, instituindo as Unidades de Gerenciamento de Recursos Hídricos (UGRHI) - embora essa instância esteja separada da efetividade de se projetar com a paisagem.

A partir da década de 1960, porém, a partir das análises e metodologias desenvolvidas sobre o planejamento ecológico e ecossistêmico da paisagem, alguns casos de recuperação de rios urbanos ou estudos relacionando a inserção e valorização dos processos naturais no processo de planejamento foram 
desenvolvidos. Assim, serão apresentados a seguir dois exemplos que são referência: o do Rio Potomac, nos Estados Unidos, e do Rio Don, no Canadá.

O Potomac River foi um estudo desenvolvido por McHarg juntamente com seus alunos do curso de Arquitetura da Paisagem e, segundo o autor, foi um teste para o método de planejamento ecológico uma vez que se tratava de uma única unidade hidrológica, a bacia - mas que cortava regiões fisiográficas diversas, em números e características - e na qual a preocupação estava em entender e avaliar todos os possíveis usos da terra (MCHARG, 1969).

O método agora pode ser desenvolvido mais completamente do que antes. E nossa intenção entender a Bacia do Rio Potomac como um processo de interação, interpretar esse sistema de valores e designar usos apropriados da terra. Agora, este não é um plano - um plano é uma determinação para alcançar certos objetivos sociais, relacionados ao poder da sociedade para alcançá-los. Não: este exercício busca apenas revelar a natureza como um armazém em operação constante, com implicações no uso e gerenciamento da terra. ${ }^{30}$ (MCHARG, 1969, p.127, grifo nosso)

Neste processo de estudo, o caminho percorrido procurou entender o clima e geologia locais; a partir de então, obteve-se a morfologia da região e então foi possível entender as regiões e perfis fisiográficos e, com eles, as diferentes interações da natureza e também a ocupação humana. McHarg descreve que o estudo serviu para mostrar que o conceito de zoneamento como conhecemos é limitado, uma vez que diversas interações e usos podem ocorrer em uma mesma área, sendo ela uma floresta ou uma comunidade urbanizada; assim, o objetivo era identificar os melhores desses usos para a bacia.

Para isso, analisa dados e produz cartografias de geologia, hidrologia, solo, fisiografia, associação de plantas, vida selvagem, problemas de água, territórios especiais, declividade e recursos minerais para, a partir da interpretação dos dados, reconhecer as singularidades ou recursos raros e propor um sistema de valores que permitirá a identificação dos melhores e mais adequados usos para cada região fisiográfica da bacia. Assim, são produzidos mapas de aptidão para agricultura,

30 "The method can now be developed more fully than before. It is our intention to understand the Potomac River Basin as an interacting process, to interpret this is a value system and to designate appropriate land uses. Now this is not a plan - a plan is a determination to achieve certain social goals, related to the power of society to accomplish these. No: this exercise seeks only to reveal nature as a working storehouse, with implications for land use and management." (MCHARG, 1969, p.127) 
silvicultura, recreação, urbanização e, por fim, um mapa síntese de aptidões (figura 7).

Figura 7 - Mapa síntese de aptidões.

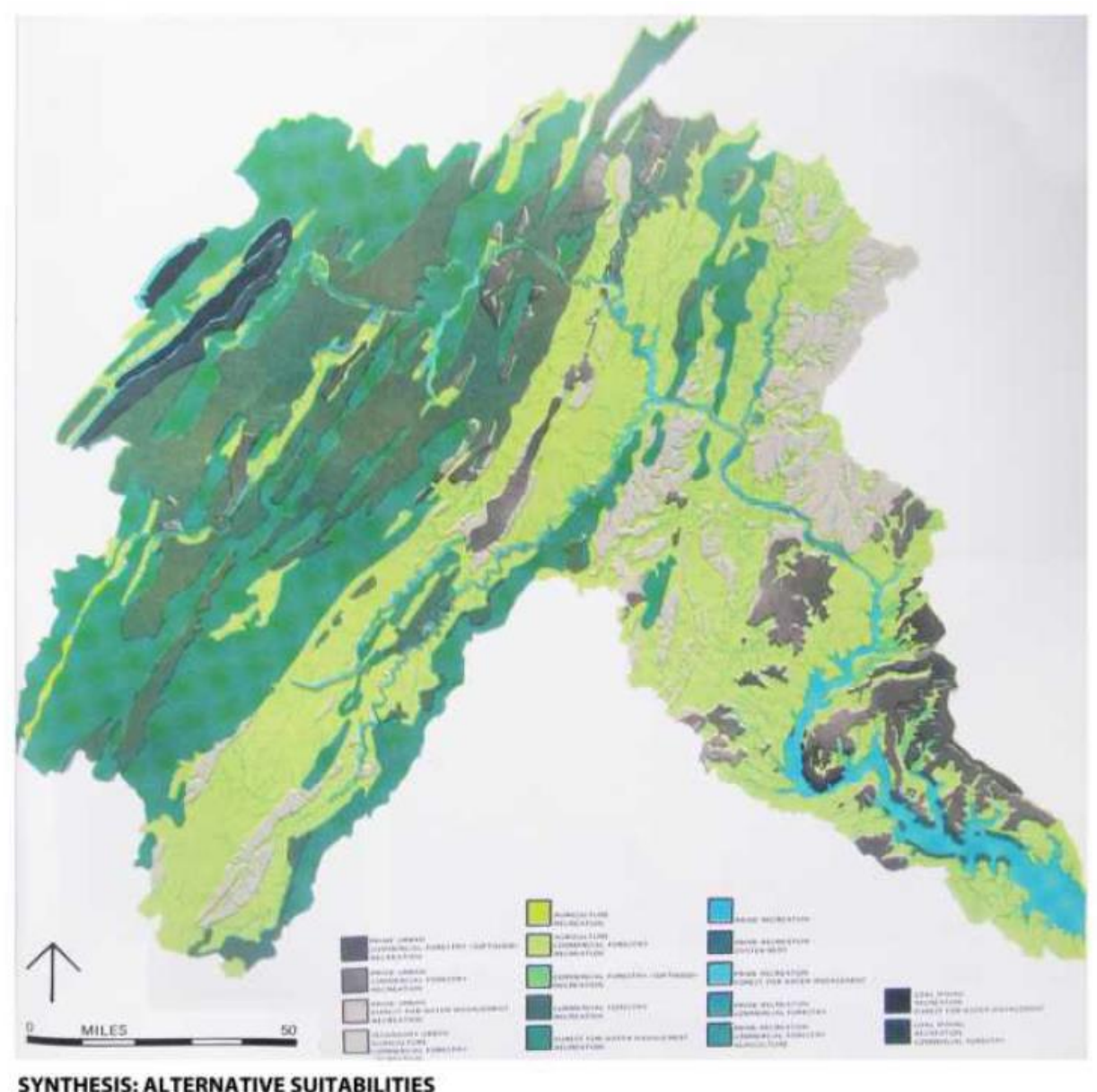

Fonte: McHarg (1969, p. 145)

Com a intenção de descobrir múltiplos usos para as áreas, cada item foi testado contra os outros até a obtenção de uma matriz (figura 8) que apresentasse o grau de compatibilidade para os usos na Bacia do Rio Potomac: "quando os resultados da matriz são aplicados, a conjunção potencial máxima de usos da terra coexistentes e compatíveis para a bacia é revelada"31 (MCHARG, 1969, p. 144). Por sua análise de múltiplas informações para identificar múltiplos usos da terra - além das cartografias, fotografias e dados analisados - o estudo para a Bacia do Rio Potomac é considerado uma das mais completas aplicações do seu método de planejamento ecológico.

31 "When the results of the matrix are applied, the maximum potential conjunction of coexisting and compatible land uses for the basin is revealed."(MCHARG, 1969, p. 144) 
Nas palavras McHarg (1969):

Esse é o método - um simples exame sequencial do local para entendê-lo. Essa compreensão revela o lugar como sistema de interação, armazenamento e sistema de valores. A partir dessas informações, é possível prescrever potenciais usos da terra - não como atividades únicas, mas como uma associação delas.

Não é uma pequena reivindicação, não é uma pequena contribuição: mas parece que o método ecológico pode ser empregado para entender e formular um plano com a natureza, talvez projetar com a natureza ${ }^{32}$ (MCHARG, 1969, p. 151, grifo nosso).

Figura 8 - Matriz elaborada por McHarg para a Bacia do Rio Potomac.

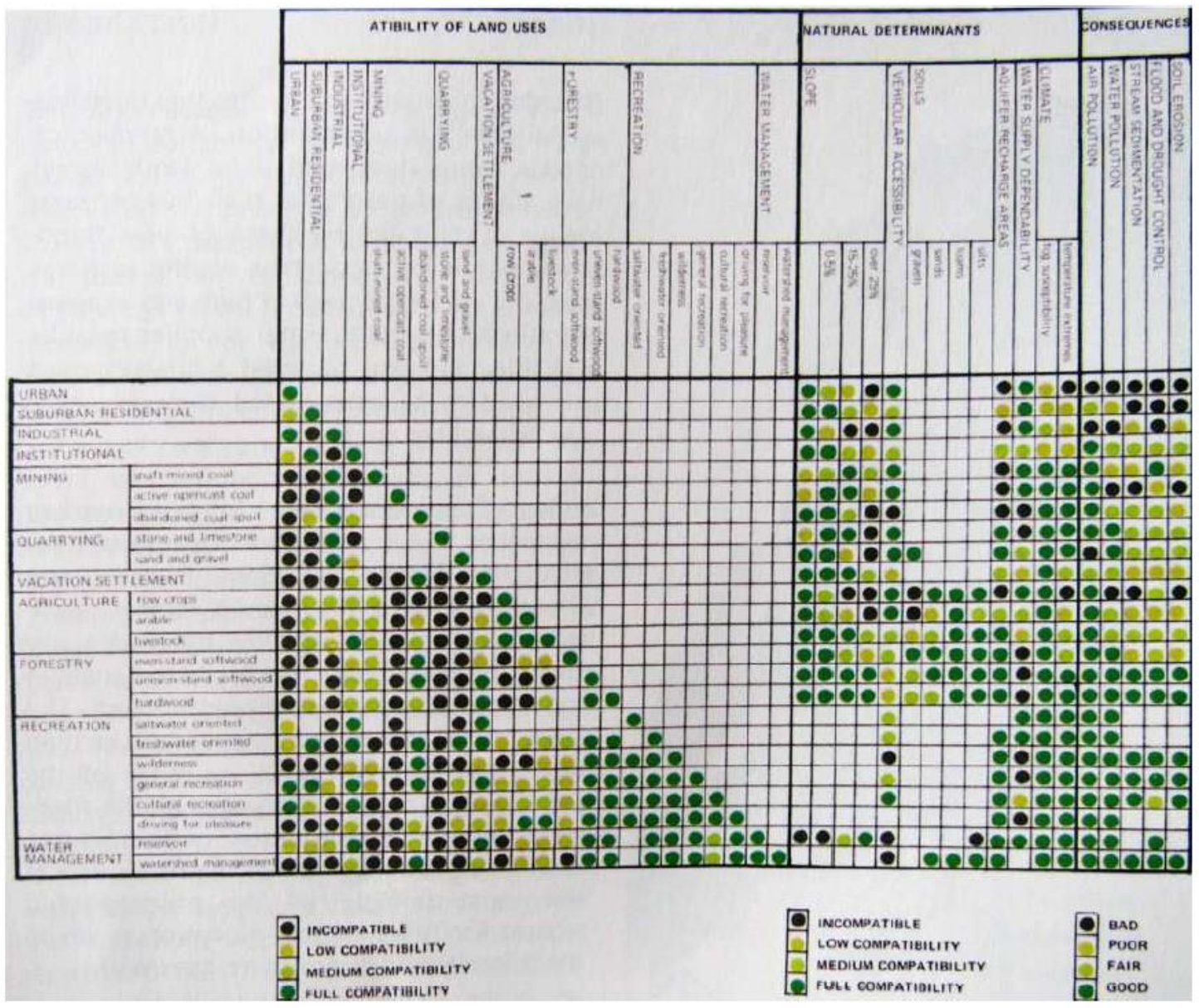

Fonte: McHarg (1969, p. 144)

32 "Such is the method - a simple sequential examination of the place in order to understand it. This understanding reveals the place as an interacting system, $s$ storehouse and a value system. From this information it is possible to prescribe potential land uses - not as single activities, but as associations of these.

It is not a small claim, it is not a small contribution: but it would appear that the ecological method can be employed to understand and formulate a plan with nature, perhaps design with nature". (MCHARG, 1969, p. 151). 
Sendo a água fundamental nos sistemas urbanos, seu uso e gestão deveriam ser controlados e planejados, tanto no caso do abastecimento quanto no de destino das águas residuais, pluviais e fluviais. Conforme foi posto ao longo deste trabalho, os processos de expansão e crescimento das cidades provocaram e foram responsáveis por um descompasso de ações no meio ambiente e nos processos naturais. Destes, a água talvez seja o elemento mais emblemático: ao mesmo tempo em que necessita de água potável, a sociedade se encarregou de tratar os rios e águas urbanas como entraves ao crescimento e como repositório de tudo aquilo que ela não quer ver na superfície para que seja levado: esgoto, poluição, lixo.

Assim, historicamente, redes de drenagem foram construídas, rios foram retificados, canalizados, tamponados, invisibilizados; suas várzeas e margens foram ocupadas e apropriadas por usos incompatíveis. Porém, como abordado, a natureza está na cidade porque a cidade é parte da natureza; e deste modo, as chuvas relembram a população de que as águas urbanas existem e que precisam de tratamento e adequadas ações de planejamento.

Conforme escreve Hough (1998), "o preço dos benefícios de ruas e espaços urbanos bem drenados são as margens erodidas dos rios, as inundações, a deterioração da qualidade da água e o desaparecimento da vida aquática" 33 (HOUGH, 1998, p. 47). Para que uma mudança ocorra, é necessário, sobretudo, reativar e reeducar o olhar da população, tornando aparente os processos que sustentam a vida $(\mathrm{HOUGH}, 1998)$.

[...] manter os sapatos secos na cidade garante que as pessoas permaneçam ignorantes sobre de onde a água vem ou para onde está indo. A água é drenada [...] e desaparece da consciência humana, perpetuando práticas que são ambientalmente destrutivas. $O$ modo como são usados a água e outros sistemas urbanos que sustentam a vida não é visível [...]. O princípio da visibilidade [...] é, portanto, crítico para alcançar um comportamento ambiental responsável. ${ }^{34}$ (HOUGH, 1998, p. 48, grifos nossos)

\footnotetext{
33 "El precio de los beneficios de las calles y espacios urbanos bien drenados son los bordes erosionados de los ríos, las inundaciones, el deterioro de la calidad del agua y la desaparición de la vida acuática." (HOUGH, 1998, p. 47)

34 "[...] mantener los zapatos secos en la ciudad asegura que la gente permanezca ignorante sobre dónde viene el agua o adónde va. Se drena el agua [...] y desaparece de la conciencia humana, perpetuando unas prácticas que son medioambientalmente destructivas. El modo en que se emplea el agua y otros sistemas urbanos que sostienen la vida, no es visible [...]. El principio de visibilidad tratado en el capítulo 1 es, por tanto, crítico para conseguir un comportamiento medioambiental responsable." (HOUGH, 1998, p. 48)
} 
Em uma maneira de reconverter um rio urbano e sua paisagem através de um processo de planejamento e projeto para toda a bacia, no qual se tornassem visíveis os processos e sistemas, Michael Hough nos apresenta o caso do Rio Don, no Canadá.

Situado em uma bacia que abrange a Grande Toronto, no Canadá, o rio Don foi urbanizado e muito degradado ao longo de duzentos anos, resultando em processos que geraram poluição, perda de diversidade ecológica e de sua significação para a população. Ao longo de sua história, foi visto como entrave ao crescimento, sua vegetação ciliar foi suprimida, teve suas áreas de várzea e pântano drenadas e aterradas, seus meandros foram retificados (figura 9), teve trechos canalizados, margens transformadas em pistas para automóveis, além de linhas de trem, linhas de transmissão de energia elétrica, e também serviu como área de descarte de lixo.

Nas palavras de Hough (1998, p. 51): "seu sentido de totalidade, beleza e lugar são [eram] somente uma lembrança" ${ }^{35}$, uma vez que "a cidade virou as costas para o rio e este tornou-se um vazio entre espaços, ao invés de ser ele próprio um espaço"36 (HOUGH, 1998, p. 56).

35 "Su sentido de totalidad, belleza y lugar son sólo un recuerdo" (HOUGH, 1998, p. 51)

36 "[...] la ciudad ha dado espalda al río y éste se ha convertido en un vacío entre espacios, en lugar de ser un espacio en sí mismo." (HOUGH, 1998, p. 56) 
Figura 9 - À esquerda, meandros originais do Rio Don (Canadá), sobrepostos ao canal gerado pela urbanização da área. Á direita, a relação dos bairros do entorno com o acesso ao local.
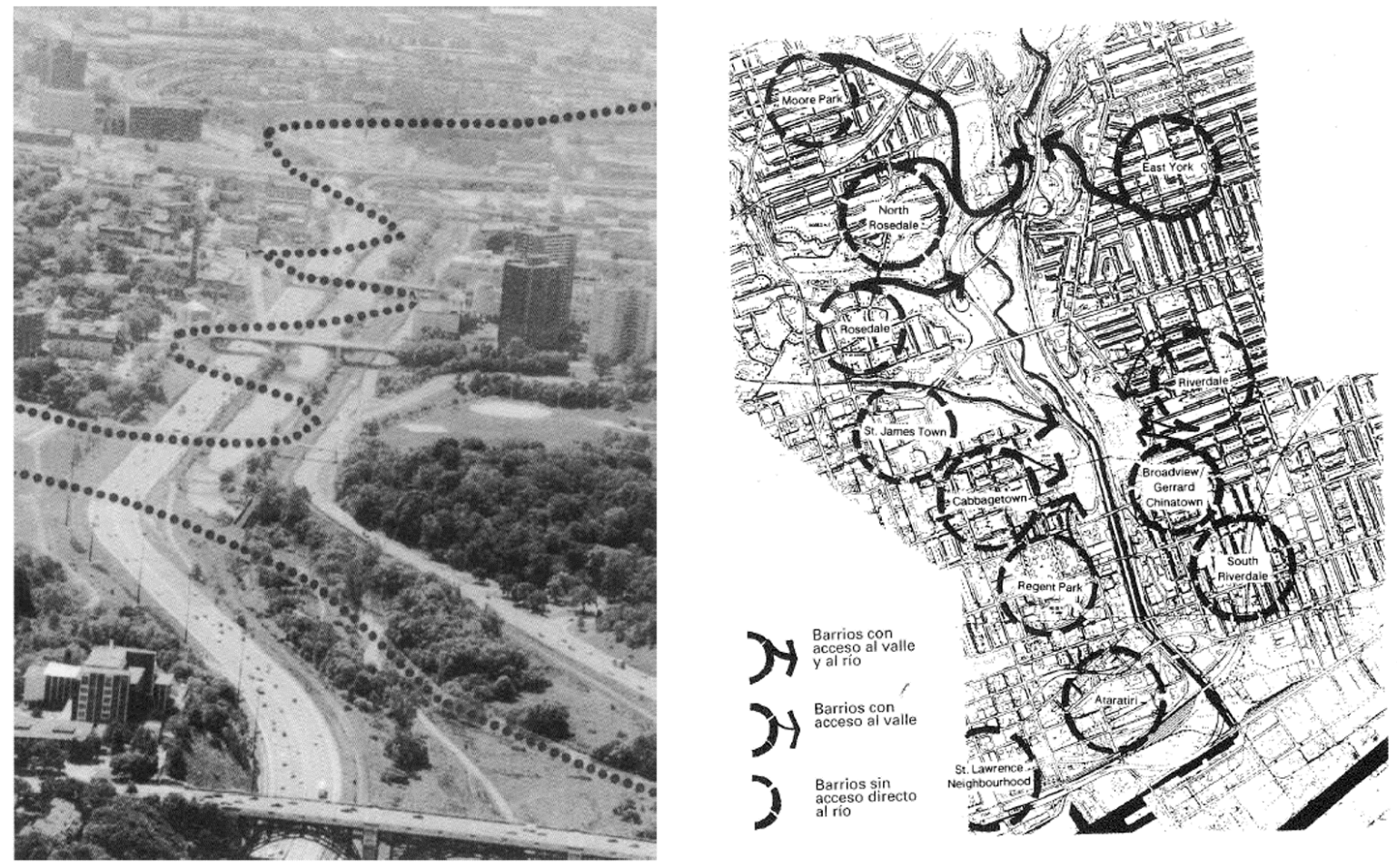

Fonte: Hough (1998, p. 56 e 58, respectivamente).

O desejo de restaurar o rio deu início a um movimento, inicialmente informal e composto por cidadãos comuns - intitulado The Task Force to Bring Back the Don ${ }^{37}$ -, até ser formalizado pela cidade de Toronto em 1990. O processo se iniciou pela parte mais degradada, porém tendo a recuperação da bacia - que se encontra $70 \%$ urbanizada - como propósito; as ações na parte mais baixa do vale incluíram o restabelecimento ecológico, políticas de conscientização e educação sobre os processos presentes no vale e a conexão do rio Don com o lago Ontario.

Foram feitas análises sensoriais nos espaços do vale, documentando os processos encontrados, os marcos na paisagem, as características naturais do local, seus limites e acessos, a biodiversidade ainda existente, a poluição sonora, industrial, visual, o microclima. Além disso, as análises de dados, mapas e histórico de ocupação reforçaram que nunca houvera uma política pública de planejamento para o vale como um todo.

As análises encontraram três unidades de paisagem melhor definidas no vale do rio Don e então foram estabelecidas as diferentes estratégias para a restauração do curso d'água e seu entorno, bem como de sua diversidade e sua relação com a

${ }^{37}$ A força-tarefa para trazer de volta o Don. 
cidade e a população. As unidades se definem pela foz do rio, área portuária e de vias elevadas; a parte mais urbana do rio, que fora canalizada; e, por fim, sua seção superior, que mantém ainda o traçado natural do curso d'água e apresenta grandes planícies inundáveis. As ações específicas para cada unidade podem ser identificadas na figura 10.

Figura 10 - Plano estratégico para a parte baixa do Rio Don.

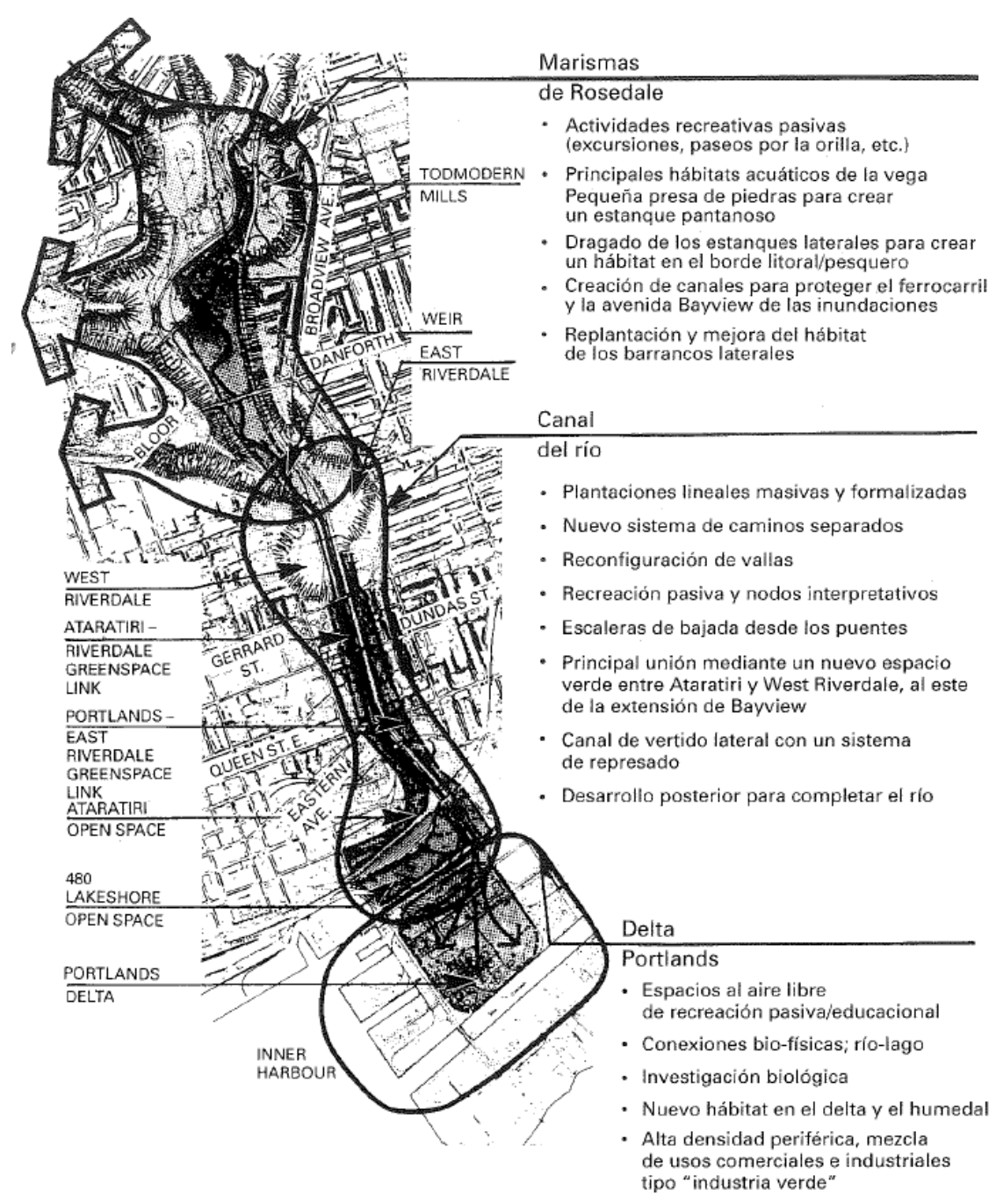

Fonte: Hough (1998, p. 63).

Além das etapas específicas para as unidades de paisagem identificadas, a restauração hidrológica do rio, de seus espaços livres e dos processos biofísicos demandavam um plano geral para o curso d'água. Pesquisas mostraram que a formação de um delta em sua foz seria capaz de conectar o rio com o lago Ontario e contribuir para o restabelecimento da biodiversidade - porém, desde o início de sua 
ocupação, como uma forma de diminuir inundações, os sedimentos acumulados eram drenados e removidos.

Então, foram desenvolvidas ações em sua foz - como o a recuperação dos pântanos e áreas sedimentares - e também rio acima, com foco na recuperação dos meandros e criação de lagoas - para desenvolvimento da vida aquática - e, na parte mais superior, projetos de lagos e áreas alagáveis, com o intuito de melhorar a qualidade da água também criar áreas inundáveis nos espaços livres do rio, controlando de maneira mais eficiente a velocidade e fluxo das águas pluviais.

Para o entorno urbano do rio, foram propostos usos mistos - residenciais, comerciais e de indústrias não poluentes. Partindo da foz, com características mais pantanosas, rio acima a população encontraria novos acessos ao canal, trechos de ciclovia, orla do rio arborizada, espaços de descanso, lazer e encontro - enfim, um rio mais urbano, com um projeto mais formal e que permitisse, ainda assim, que os cidadãos tivessem contato com os processos - ver, ouvir, sentir a água. Por último, na parte superior, uma terceira e quarta paisagens, envolvendo planícies de inundação, campos, caminhos e, enfim, a conexão do local com os bairros do entorno e com outros parques urbanos, através de espaços arborizados - um sistema.

Assim, a população teria contato com um grande espaço ao ar livre e, então, os cidadãos teriam contato com os processos e aprenderiam com o funcionamento da bacia do rio Don e seu processo de restauração a valorizar a beleza de um vale outrora degradado (HOUGH, 1998).

Hough destaca também a importância das diferentes escalas de ações para a execução do projeto: o que começou com uma ideia de poucos cidadãos, foi adotada por uma comunidade e apoiada por políticas públicas e comissões de planejamento, além de interesses privados. A efetividade do projeto em termos de gestão deveu-se à criação, por exemplo, de legislações e planos próprios para o vale, contemplando instrumentos urbanísticos para a criação dos espaços livres e mecanismos de controle dos usos do solo e de desenvolvimento do entorno; além disso, acordos entre as instituições ligadas ao rio - energia, transporte, saneamento - e também entre todas as cidades pertencentes à bacia do rio Don, para que fossem desenvolvidas em conjunto as atividades propostas pelo projeto.

Como um processo contínuo de renovação e cura, a estratégia do Don colocou em jogo princípios-chave, incluindo uma compreensão fundamental dos processos como uma idéia biológica integrada às agendas sociais, econômicas e políticas, com uma economia de meios 
na qual, com um aporte mínimo de energias e esforços, se alcance o maior benefício, e com uma educação ambiental em que o entendimento da natureza nas cidades faça parte de uma experiência de aprendizado que comece com a ação e a autorização da comunidade. ${ }^{38}$ (HOUGH, 1998, p. 70)

A tarefa atual é criar um novo simbolismo de projeto para a água (e para os sistemas naturais urbanos como um todo) que reflita os processos hidrológicos da cidade; uma linguagem de projeto que restaure a identidade de processos vitais; [...] As forças motrizes que moldaram os sistemas e tecnologias convencionais da cidade foram baseadas no encobrimento dos processos que a sustentam. Revelar e enriquecer os processos da natureza e a diversidade da paisagem cultural da cidade está, portanto, no cerne da experiência urbana e da forma artística. ${ }^{39}$ (HOUGH, 1998, p. 81-83)

Gorski (2010) também analisa diversos projetos pautados na recuperação de rios incluindo casos como o próprio rio Don, além de projetos brasileiros, como a requalificação da rua do Porto e o rio Piracicaba - e a reconversão de seus papéis na sociedade e no meio urbano e faz, assim, uma síntese das ideias, apresentando "Dez recomendações para projetos de recuperação de rios urbanos":

1. "Proteger ou recuperar as características funcionais e morfológicas dos rios, evitando estrangulamentos, tamponamentos, canalizações, mantendo ou recuperando vegetação ripária e criando um sistema de parques lineares, articulados a um sistema de espaços verdes urbanos;

2. Valorizar as paisagens fluviais como áreas de proteção e de lazer ativo e passivo, incorporando a dimensão estética como um fator relevante do projeto;

3. Integrar o plano de recuperação de rios urbanos aos planos diretores municipais, engajando a sociedade civil e se articulando a outras esferas do poder, tanto no sentido vertical como horizontal;

4. Inserir o plano ou projeto na escala da bacia hidrográfica;

5. Valorizar o patrimônio ambiental, histórico e cultural;

6. Implantar plano de drenagem urbana e tratamento de resíduos, aplicando as medidas adotadas pelos manuais do LID ou BMP, conhecidas como infraestrutura verde;

38 "Como un proceso continuo de renovación y curación, la estrategia del Don puso en juego principios claves, incluyendo una comprensión fundamental de los procesos como una idea biológica integrada con las agendas sociales, económicas y políticas, con una economía de medios en donde, con un mínimo aporte de energías y esfuerzos, se consiga el mayor beneficio, y con una educación medioambiental en la que el entendimiento de la naturaleza en las ciudades forme parte de una experiencia de aprendizaje que comience con la acción y la autorización de la comunidad." (HOUGH, 1998, p. 70)

39 "La tarea actual es crearan nuevo simbolismo de diseño para el agua (y para los sistemas urbanos naturales en su totalidad) que refleje los procesos hidrológicos de la ciudad; un lenguaje de diseño urbano que restablezca la identidad de los procesos vitales; [...] Las fuerzas motrices que han dado forma a los sistemas y tecnologías convencionales de la ciudad se han basado en el encubrimiento de los procesos que las sostienen. Revelar y enriquecer los procesos de la naturaleza y la diversidad del paisaje cultural de la ciudad yace, por lo tanto, en el corazón de la experiencia urbana y de la forma artística." (HOUGH, 1998, p. 81-83) 
7. Conscientizar políticos, gestores, técnicos e sociedade acerca da importância dos rios e dos elementos bióticos e abióticos no meio urbano e evitar empreendimentos e obras de infraestrutura de impacto nas vizinhanças do rio;

8. Rever o sistema viário a partir do leito fluvial incorporando um sistema multimodal, e garantir o acesso da população ao rio assegurando o balanço de uso recreacional e proteção;

9. Criar oportunidades de trabalho e atividades de uso múltiplo que garantam a vitalidade das áreas de vizinhança;

10. Criar programas de voluntariado, capacitação e educação ambiental para a população." (GORSKI, 2010, p. 282 e 283)

Spirn (1995) também propõe um plano para o manejo das águas urbanas, otimizando a recuperação das mesmas e prevenindo enchentes, além de conservar os recursos hídricos. Para isso, propõe, resumidamente:

a) "Projetar parques nas várzeas capazes de estocar as águas e resistir aos danos das enchentes (SPIRN, 1995, p. 185);

b) Reutilizar a água das chuvas para irrigar as plantas e, ao mesmo tempo, escolher espécies resistentes.

c) "Explorar a capacidade dos telhados, das praças, dos estacionamentos e do solo para reter ou absorver o escoamento de aguaceiros" (SPIRN, 1995, p. 185)

d) Proteger as áreas de mananciais e de recarga, em especial àquelas que são utilizadas para abastecimento da população;

e) Promover a não ocupação por novos edifícios e loteamentos das áreas de várzeas sujeitas a inundações;

f) "Localizar nas cabeceiras e nas várzeas a jusante novos parques e áreas verdes para preservar a capacidade de armazenamento das águas, e para melhorar a recarga dos lençóis freáticos" (SPIRN, 1995, p.184).

Algumas das ações citadas acima possuem baixo impacto de realização, menor custo de implantação e, contudo, alto desempenho; e podem representar o início de um processo de recuperação e controle das águas urbanas; são estratégias que participam dessa mudança de paradigma conhecido como infraestrutura verde.

\subsubsection{Infraestrutura verde}

Sistemas de drenagem transportam a água de um ponto para outro; eles não reduzem nem eliminam água, apenas mudam sua 
localização. A prática tradicional de drenagem protege ruas locais, subterrâneos e estacionamentos contra as enchentes, enquanto contribuem para um dano maior de inundação mais abaixo (SPIRN, 1995, p. 147).

O armazenamento da água das cheias e o lazer são compatíveis nos grandes parques urbanos. Parques que exploram a capacidade natural do armazenamento de água das cheias das várzeas desenvolvem as margens para espaços públicos (SPIRN, 1995, p. 163).

Infraestrutura Verde (IV) é "uma maneira de reconhecer e aproveitar os serviços que a natureza pode realizar no ambiente urbano" (CORMIER E PELLEGRINO, 2008); o termo foi utilizado pela primeira vez em 1994 nos relatórios da Comissão de Greenways da Flórida, citando a infraestrutura verde e a importância de seus sistemas naturais no contexto urbano como tão ou mais importantes que a conhecida infraestrutura convencional, ou "cinza” (FIREHOCK, 2010).

A infraestrutura cinza, ou engenharia cinza, é aquela que aplica ao meio físico os conhecimentos provenientes de modelos matemáticos e fórmulas, aliando processos que interrompem etapas dos sistemas naturais. Assim, canalização de córregos, construção de galerias, estreitamento do leito de rios, tamponamento dos mesmos, são processos que aplicam a engenharia cinza, com o amplo uso de concreto e impermeabilização de superfícies. Como relata Spirn: "sistemas de drenagem transportam a água de um ponto para outro; eles não reduzem nem eliminam água, apenas mudam sua localização" (SPIRN, 1995, p. 147).

A infraestrutura verde é composta por "intervenções de baixo impacto na paisagem e alto desempenho, com espaços multifuncionais e flexíveis, que possam exercer diferentes funções ao longo do tempo - adaptável às necessidades futuras" (AHERN,2009, apud HERZOG; ROSA, 2010).

Assim, entende-se a IV como uma rede interligada de sistemas naturais convivendo com a cidade e com a sociedade, conectando esta à natureza e impactando positivamente em sua qualidade de vida. Ainda segundo Pellegrino (2015), a IV é um modelo inovador de infraestrutura urbana, multifuncional e interdisciplinar, em contraste com os modelos tradicionais e tem papel estratégico no desenvolvimento de cidades mais sustentáveis e resilientes, uma vez que, ao associar-se a outros sistemas da paisagem, constituem-se em soluções multifuncionais. 
Sendo resiliência "a capacidade de um sistema absorver impactos e manter suas funções ou propósitos, sobreviver ou persistir em um ambiente com variações" (HERZOG, 2013, p. 79), cidades resilientes são, portanto, aquelas que apresentam a capacidade de suportar a impactos, absorvendo-os, convivendo com eles sem sofrer maiores danos, tratando-os e se regenerando.

O emprego da infraestrutura verde, além de reafirmar a possibilidade da convivência entre natureza e desenvolvimento urbano, construindo novas paisagens, permite ainda um aumento das atividades ecossistêmicas, melhoria do microclima, mitigação das enchentes uma vez que aumenta a absorção e infiltração das águas pluviais, diminuição de poluentes nas águas e na atmosfera, proteção dos recursos hídricos, fauna e flora, e melhoria na qualidade ambiental dos indivíduos.

As tipologias de infraestrutura verde mais comuns (CORMIER e PELLEGRINO, 2008) e (BONZI, 2015) são descritas a seguir:

a) Biovaletas: canteiros que funcionam como um canal, retardando o escoamento das águas até seu ponto mais baixo e permitindo que infiltre durante o percurso;

b) Jardins de chuva: canteiros e pequenos jardins que acumulam água das chuvas, permitindo a infiltração e retardando a devolução das águas ao sistema de captação; as espécies utilizadas nos jardins de chuva permitem ainda a remoção de poluentes;

c) (Re)Naturalização de córregos: recomposição dos cursos d'água e de suas margens, permitindo ao córrego seu destamponamento e descanalização, voltando a percorrer um curso natural e aberto;

d) Teto verde: telhados utilizados como jardins, permitindo absorção e contenção de parte das águas das chuvas;

e) Alagado construído (ou wetland): áreas vegetadas localizadas às margens dos rios, passíveis de inundação. Contribuem no processo de filtragem das águas e tem papel especial na recomposição e preservação da biodiversidade;

f) Pavimento drenante: pavimentação que permite a infiltração da água no solo (seja por material poroso, como concreto e asfalto, ou através dos pequenos espaços entre as peças (bloco intertravado, por exemplo); 
g) Cisterna: estrutura para captação e armazenamento da água das chuvas;

h) Corredores Verdes: caminhos vegetados que conectam as diferentes manchas verdes presentes na malha urbana; vão desde canteiros centrais e ruas altamente arborizadas;

A infraestrutura verde pode contribuir para a adaptação de áreas urbanas para enfrentar ocorrências climáticas ao converter áreas monofuncionais que causam impactos ecológicos em elementos que mimetizam os processos naturais. Além disso, a infraestrutura verde traz benefícios reais para as pessoas, ao transformar a paisagem urbana em áreas vivas, que aliam natureza, arte e cultura local. (HERZOG \& ROSA, 2010, p.98)

No planejamento sistêmico, é muito importante que, além dos dispositivos de uma infraestrutura verde, a cidade opere a partir de um urbanismo bioclimático; este, segundo Higueras (2010), tem como objetivo adequar o desenho urbano às condições do clima e do território, considerando que cada lugar tenha seu próprio planejamento.

Ester Higueras, no livro Urbanismo Bioclimático, publicado em 2006, também trata sobre o estudo das cidades como um ecossistema, mas neste caso observando questões morfológicas das cidades e as relações com a natureza - relevo, hidrografia, clima, entre outros - propondo estratégias de projeto - uma metodologia - para amenizar as problemáticas criadas pelo homem ao desconsiderar o meio físico ambiental no processo de planejamento.

A cidade contém uma comunidade de organismos vivos, um ambiente físico que se transforma como resultado de atividade interna e um funcionamento baseado em trocas de matéria, energia e informação que, nesse sentido, são assimiláveis a um ecossistema natural, sendo o homem e suas sociedades subsistemas do mesmo. ${ }^{40}$ (HIGUERAS, 2010, p. 60)

Em resumo, essas especificidades seriam: um traçado viário seguindo a topografia, bem como sendo considerado a direção dos ventos e a incidência solar, áreas verdes que possam promover o controle da temperatura e ampliação de umidade, morfologia urbana das quadras e tipologia dos edifícios considerando fachadas bem orientadas (HIGUERAS, 2010).

40 "La ciudad contiene una comunidad de organismos vivos, un medio físico que se va transformando fruto de la actividad interna y un funcionamiento a base de intercambios de materia, energía e información que, en este sentido, son asimilables a un ecosistema natural, siendo el hombre y sus sociedades subsistemas del mismo." (HIGUERAS, 2010, p. 60) 
A metodologia do urbanismo bioclimático (HIGUERAS, 2010) envolve um esquema com três etapas: o conhecimento do meio físico e ambiental, identificando os recursos potenciais do território, o conhecimento do clima, considerando o sol, os ventos e umidade e, por mim, o planejamento em si, que considera diretrizes para três sistemas gerais: viário, áreas verdes e equipamentos. Baseando-se em McHarg, Higueras propõe as análises a partir da leitura das várias camadas de informações que cada território oferece.

O planejamento a partir dos espaços livres configura-se como uma nova abordagem da natureza na cidade, e que tem como objetivos prioritários desde o uso destes espaços pela população e sua continuidade dentro da cidade bem como para a biodiversidade das espécies. A articulação das áreas verdes de qualquer ordem é a garantia da presença da natureza na cidade, considerando seus benefícios (HIGUERAS, 2010).

Michael Hough, em Naturaleza y Ciudad (1995), no capítulo em que aborda o clima e as conexões possíveis com o meio urbano e os processos naturais, exemplifica, através do sistema de parques em Stuttgart, Alemanha, como o planejamento destes funciona como uma infraestrutura verde para a cidade e possibilita a otimização da vida em meio urbano.

Nos parques (cobrindo cerca de 490 hectares), plantas, lagos e esculturas aquáticas foram usadas para criar locais cheios de frescor, com vistas e sons variados. Os espaços verdes são cerca de $3^{\circ} \mathrm{C}$ mais frios do que os arredores. Tanto na escala da cidade quanto na do homem, os parques e paisagens de Stuttgart e arredores estão entre os mais funcionais do ponto de vista climático, socialmente úteis e esteticamente agradáveis de qualquer cidade moderna do mundo ocidental. Do ponto de vista do planejamento da paisagem, sua influência no clima é acompanhada por sua função como uma "infraestrutura verde", dando forma e identidade à cidade. ${ }^{41}$ (HOUGH, 1998, p. 273)

O excerto acima referenda as ideias e questões pioneiras projetadas por Olmsted, pensando em ações que impactassem a sociedade como um todo: clima, cultura, arte. São espaços sociais.

\footnotetext{
41 "En los parques (que cubren unas 490 hectáreas), se han utilizado plantas, lagos y esculturas acuáticas, para crear lugares llenos de frescura, con vistas y sonidos variados. Los espacios verdes son unos $3^{\circ} \mathrm{C}$ más fríos que las áreas construidas de alrededor. Tanto a escala de la ciudad como del hombre, los parques y paisajes dentro y alrededor de Stuttgart se encuentran entre los climáticamente más funcionales, socialmente útiles y estéticamente agradables de cualquier ciudad moderna del mundo occidental. Desde una perspectiva de planificación paisajista, su influencia en el clima está igualada por su función como una "infraestructura verde", dando forma e identidad a la ciudad." (HOUGH, 1998, p. 273)
} 
Assim, infraestrutura verde e urbanismo bioclimático podem ser entendidos como ferramentas possíveis para um planejamento ecológico que envolve natureza e cidade em todos os seus processos e que foram aqui descritos porque constituem soluções e possibilidades para as problemáticas das cidades atuais - inclusive a analisada neste trabalho - que ainda enfrentam a descrença de que cidade seja parte da natureza.

No decorrer deste trabalho, abordou-se um viés teórico e histórico sobre como grande parte das cidades brasileiras cresceram e se expandiram baseadas em um modelo de planejamento dominante à época, ao mesmo tempo em que foram expostos processos, conceitos, idealizações e realizações que representavam saídas e alternativas aos modelos que se tornaram dominantes. Se o processo de planejamento e execução de nossas cidades teve uma imposição funcional, mostrouse que projetos e autores já no século $\mathrm{XIX}$, e ao longo do século $\mathrm{XX}$, pensavam de modo diferente, em teorias e práticas que atualmente denominamos como sustentáveis, mas que representam o que podemos definir como um planejamento sistêmico com a paisagem. Entendendo os processos, contextos, conexões e especificidades de cada território, esta metodologia pode ser aplicada em toda a superfície da terra, pois como outrora dito "a natureza é ubíqua, um todo que envolve a cidade" (SPIRN, 1995, p. 21).

Desse modo, partimos para a caracterização e descrição de uma cidade em específico: Presidente Prudente, estado de São Paulo, país Brasil. 


\section{CAPÍTULO III - PRESIDENTE PRUDENTE: HISTÓRIA, CRESCIMENTO E PROCESSOS DE PLANEJAMENTO}

Presidente Prudente está localizada no extremo oeste do estado de São Paulo e possui população de 207.610 habitantes (IBGE, 2010) - 228.743 habitantes na projeção atualizada para o ano 2019. É conhecida como a capital da Alta Sorocabana - em referência à antiga estrada de ferro Sorocabana, que corta suas terras - sendo sede regional de governo (figura 11). Foi fundada em 1917 a partir da junção das vilas Goulart e Marcondes, adquirindo caráter de município em 1921 e tem seu crescimento ligado à expansão da produção cafeeira no oeste do estado.

Figura 11 - Região administrativa de Presidente Prudente, com o município em destaque

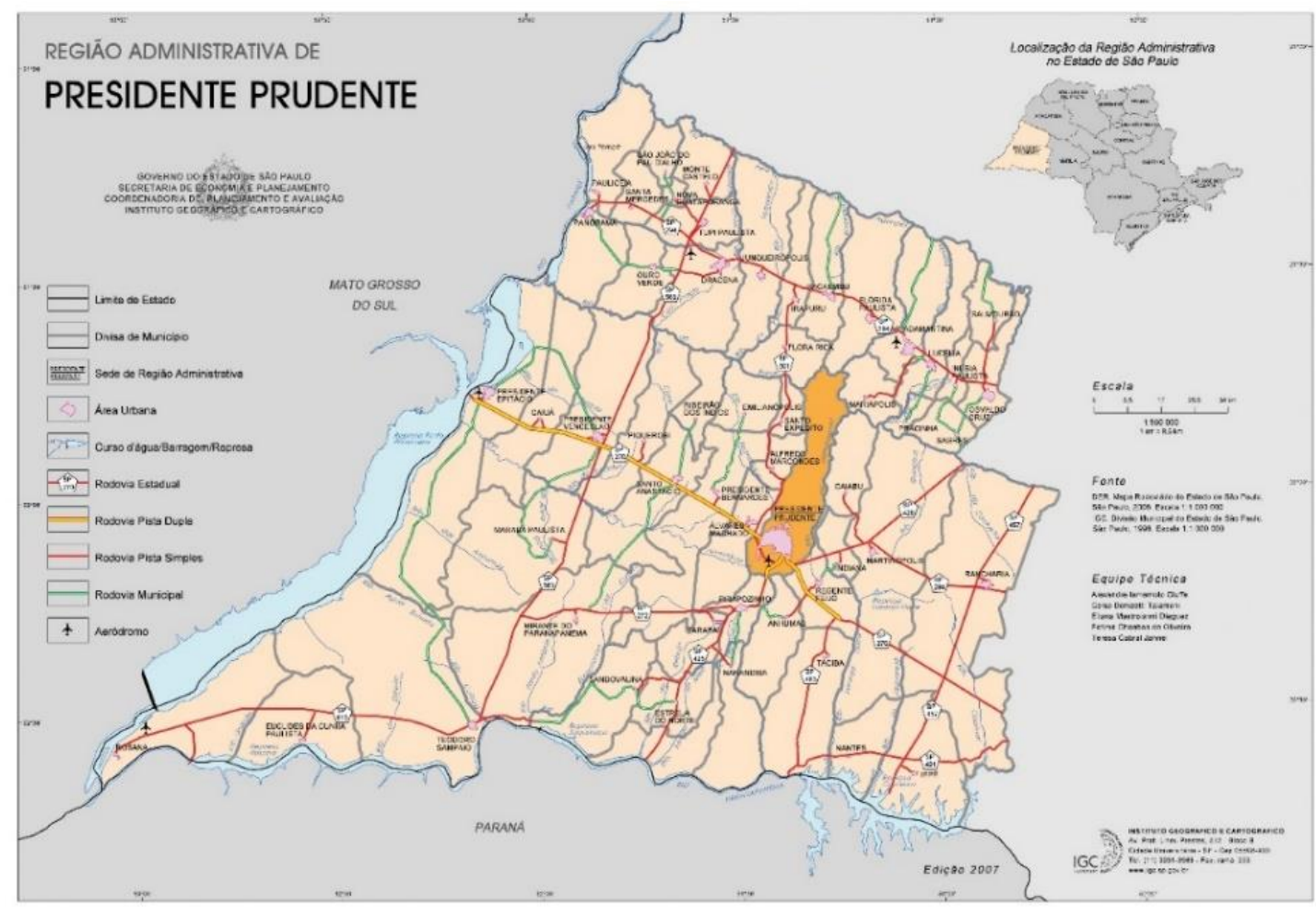

Fonte: IGC (Instituto Geográfico e Cartográfico).

O município tem seu território localizado na bacia hidrográfica do rio Paraná, dentro de duas unidades de gerenciamento de recursos hídricos (UGRHI) - que são o conjunto de divisões das bacias hidrográficas no estado de São Paulo (figura 12). Uma das unidades é a do rio do Peixe e a outra, a do Pontal do Paranapanema. 
Figura 12 - Unidades de Gerenciamento de Recursos Hídricos (UGRHI) do estado de São Paulo, com demarcação do município de Presidente Prudente (entre as unidades 21 e 22 do mapa).
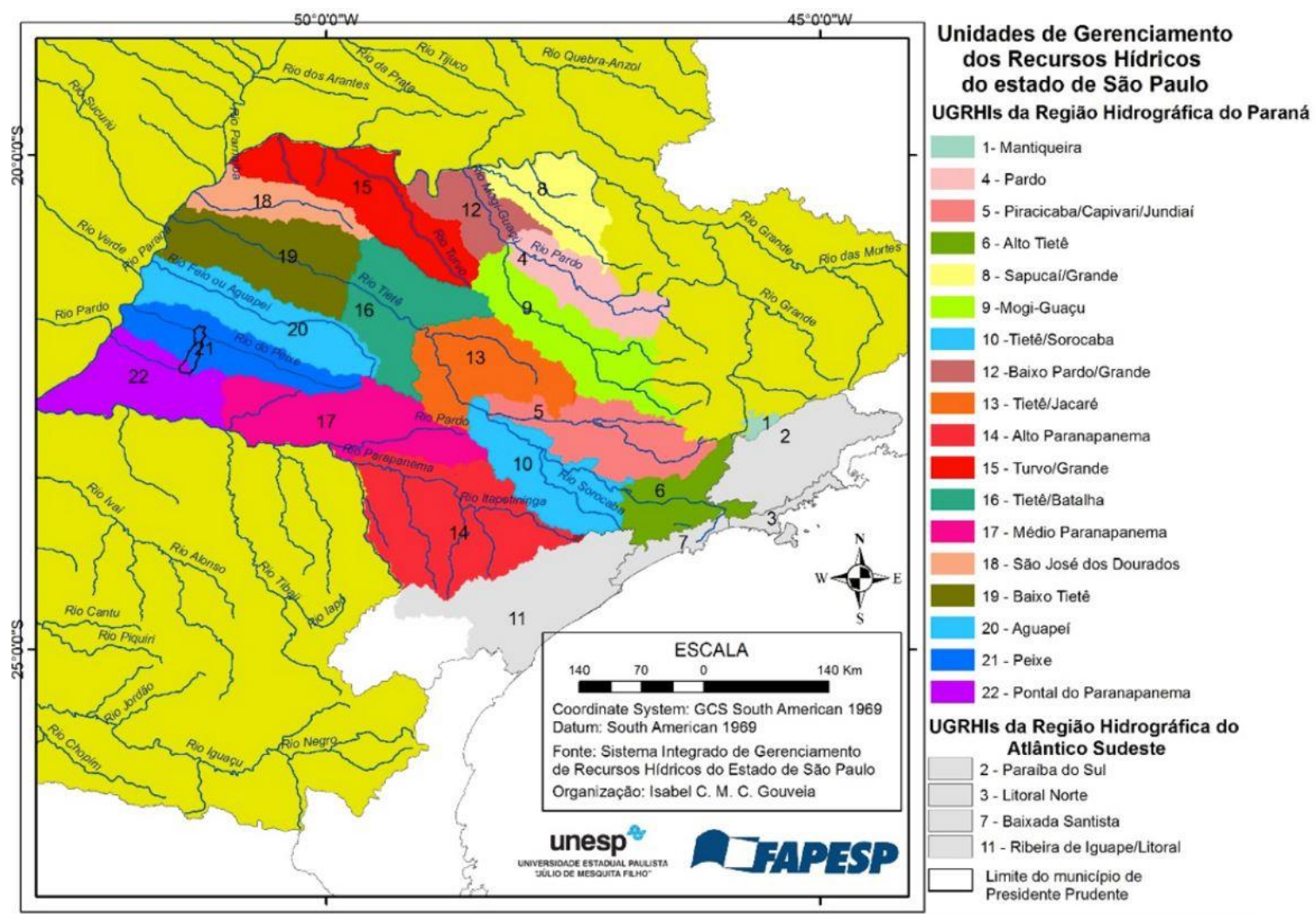

Fonte: Nunes et al (2017). Disponível em: http://portaldoprofessor.fct.unesp.br:9000/. Acesso em 18 de julho de 2018.

A partir dessa leitura da geografia física, e tendo o espigão, por onde foi construída a linha férrea, como divisor - no sentido norte-sul - (figura 13), a porção territorial a oeste apresenta a distribuição da maior parte da malha urbana, a qual está inserida na bacia do Ribeirão Santo Anastácio, que pode ainda ser dividida em outras sub-bacias: a do Córrego do Cedro e a do Córrego do Limoeiro. Essa última apresenta uma sub-bacia completamente urbana, objeto de estudo e recorte desse trabalho, a do córrego do Veado; a outra porção territorial, a oeste do espigão, está vinculada à bacia do rio do Peixe. Dentro dos limites do perímetro urbano, Presidente Prudente apresenta 365,05 Km de canais fluviais (NUNES et al, 2017). 
Figura 13 - Recorte do mapa hipsométrico de Presidente Prudente, evidenciando as diferentes classes altimétricas dentro do perímetro urbano (contorno preto).

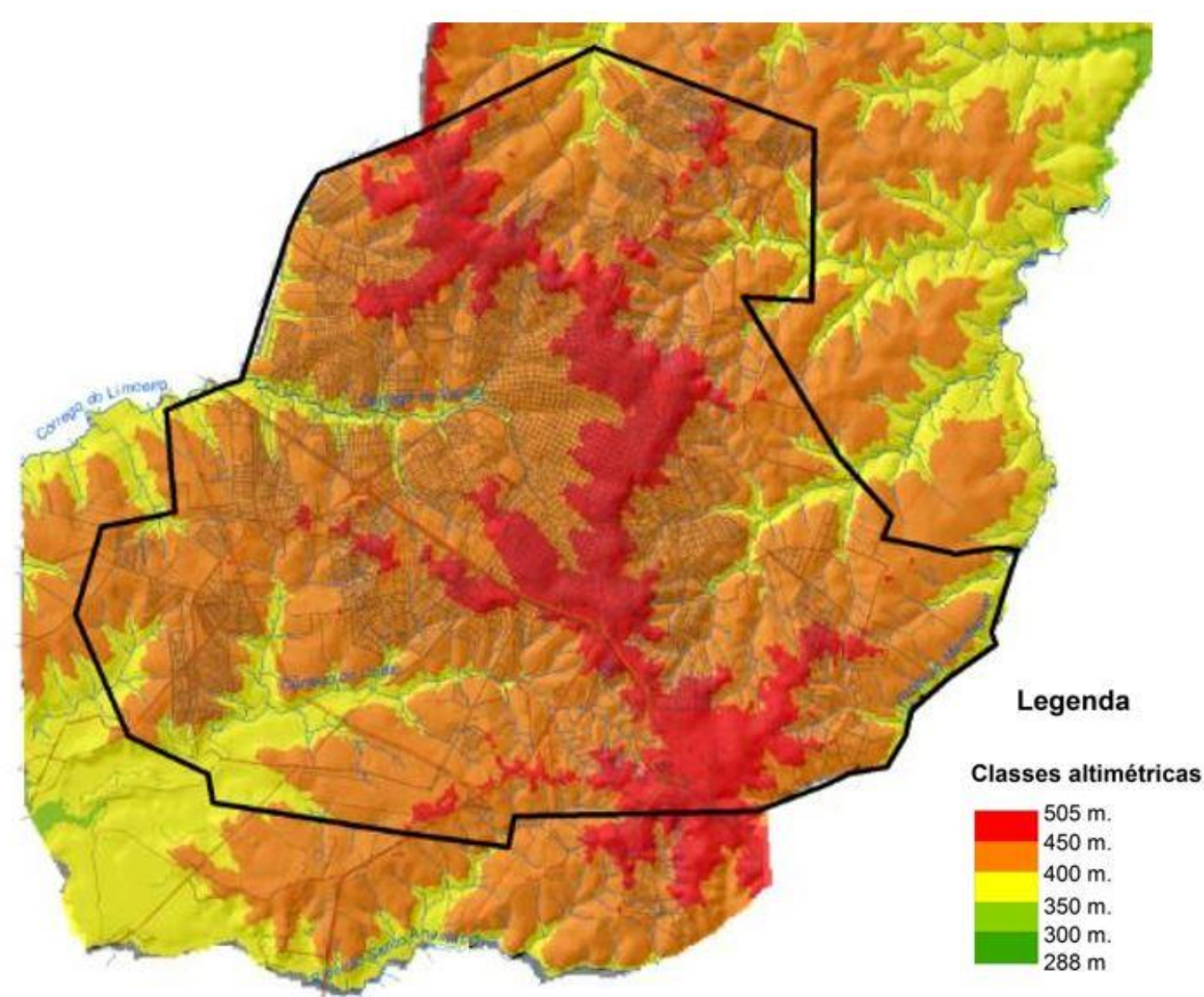

Fonte: Nunes et al (2017). Disponível em: http://portaldoprofessor.fct.unesp.br:9000/. Acesso em 18 de julho de 2018.

Referenciada como "cidade 300\%", Presidente Prudente tem 100\% (99,8\%) de abastecimento de água tratada, $100 \%(99,4 \%)$ de coleta de esgoto e $100 \%$ de esgoto tratado, segundo a Prefeitura Municipal.

a) O abastecimento de água vem de mananciais superficiais: $75 \%$ do rio do Peixe, $25 \%$ do rio Santo Anastácio (através de uma represa formada pelas águas dos córregos Botafogo, Cedro e Cedrinho) e, em casos emergenciais, tem-se a represa formada pelo Balneário da Amizade, na divisa com o município de Álvares Machado.

b) A estação de tratamento de esgoto funciona desde 2004 e está localizada às margens do córrego do Limoeiro, no qual tributa o córrego do Veado (principal bacia urbana). 
Devido à localização da mancha urbana, que se iniciou e se desenvolveu sobre espigão das terras do município, Presidente Prudente apresenta uma peculiaridade: retira a maior parte de sua água para abastecimento do rio do Peixe, em um sistema de captação distante $42 \mathrm{~km}$ - quarenta e dois quilômetros - da área urbana, enquanto a maior parte de suas águas residuais, após o tratamento, são despejadas no córrego do Limoeiro, que compõe a bacia do Santo Anastácio, localizada na Unidade Hídrica do Pontal do Paranapanema.

\subsection{Histórico: surgimento e desenvolvimento até a década de 1950}

A ocupação da região oeste do estado de São Paulo se inicia ainda no século XIX, tendo duas frentes importantes: a dos plantadores de café e o próprio governo federal, que tinha uma preocupação relacionada ao controle das terras e fronteiras: 0 rio Paranapanema é afluente do rio Paraná e forma uma das principais fronteiras do país sendo uma porta estratégica de entrada fluvial do país e da América do Sul lembrando que a Guerra do Paraguai esteve em curso entre 1864 e 1870.

Como relata ABREU (1972), a região oeste era ocupada por regiões de mata, sendo que:

A qualidade da madeira aí encontrada estabelecia o padrão da terra: pau d'alho, peroba, Cabreúva, cedro, chimbuva, jataí, jacarandá. A qualidade desta terra atraiu os plantadores de café, mas houve grande dificuldade para a penetração do homem, porque os índios, geralmente hostis, preferiam a mata para habitar. Daí as primeiras penetrações terem sido feitas seja através dos afluentes paulistas do Paranapanema [...], seja pelos afluentes paranaenses [...]. (ABREU, 1972, p. 17)

Assim, a terra fértil começou a atrair um número cada vez maior de desbravadores e o governo federal estimulou a implantação de ramais ferroviários na região, colaborando para sua efetiva ocupação. Leite (1998) ainda destaca:

No caso do sudoeste do estado, a ocupação do território somente se efetivou com a abertura da Estrada de Ferro Sorocabana. Fortemente incentivada pelo governo federal, por razões militares e políticas, a estrada de ferro, antecedendo o café, cortou os sertões em busca do rio Paraná. (LEITE, 1998, p. 32)

A Estrada de Ferro Sorocabana se expande, partindo de Botucatu a partir de 1889, chegando a Ourinhos em 1908, a Presidente Prudente em 1919 e a Porto 
Epitácio, às margens do rio Paraná, em 1922 (figura 14) tendo real impacto na ocupação populacional e no desenvolvimento de toda a região.

Figura 14 - Estado de São Paulo: cidades, inauguração das estações ferroviárias e expansão cafeeira.

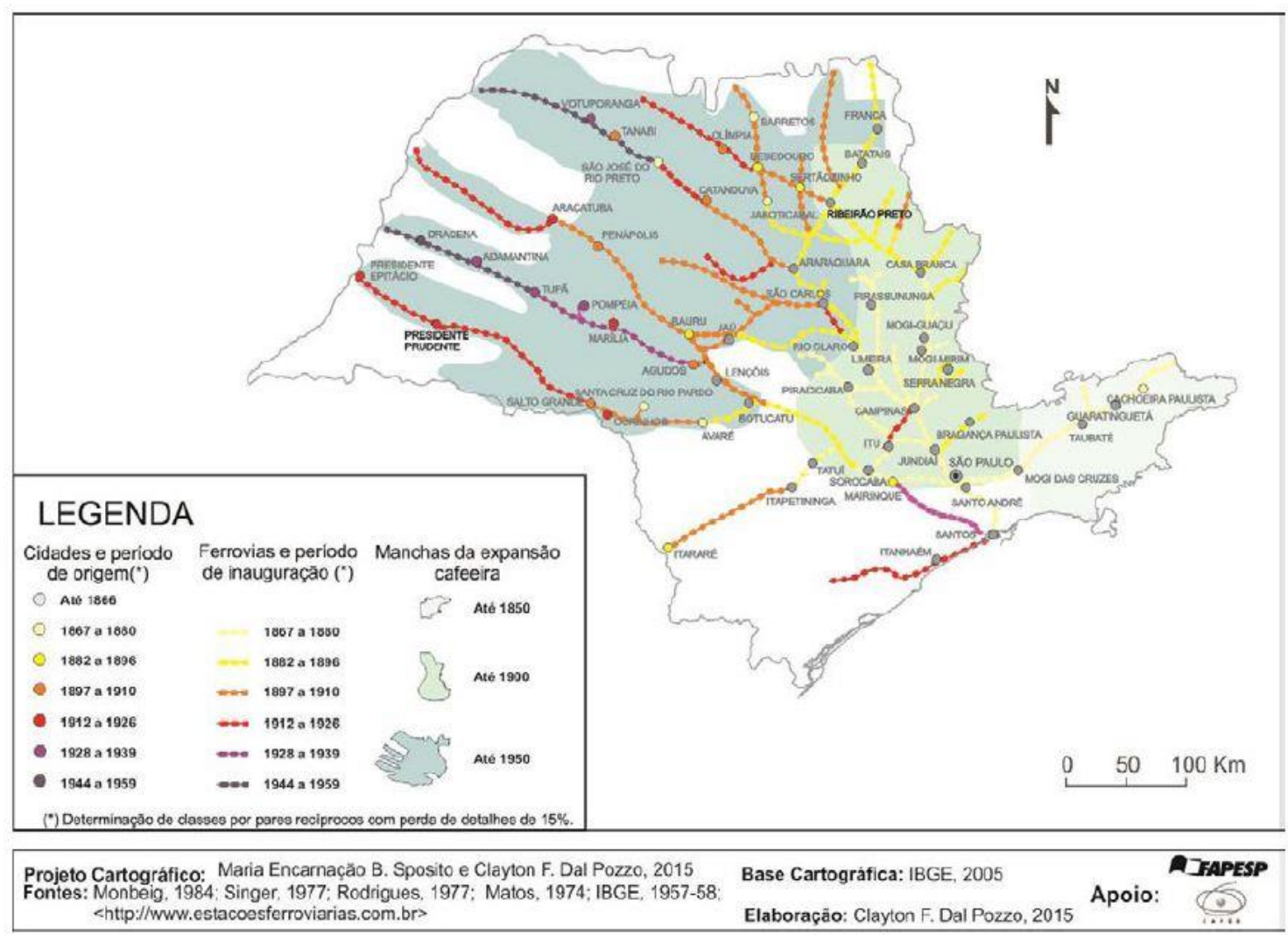

Fonte: Dal Pozzo (2015).

Como relata Abreu (1972), após a crise na mineração e à exaustão do solo no vale do Paraíba, os plantadores passaram a buscar novas terras para plantio do café, chegando, no início do século XX às terras roxas existentes nos espigões do oeste paulista, entre os rios do Peixe e Paranapanema, até atingirem a margem esquerda do rio Paraná.

O café valorizou e povoou as terras "descobertas" pelos povoadores mineiros. Esta segunda colonização foi feita de modo original, pois além dos proprietários das zonas cafeeiras mais antigas, que abriam novas fazendas aproveitando a boa situação do café, veio o negociante de terras para adquirir glebas com as quais pudesse especular com os que chegavam depois. (ABREU, 1972, p.35)

Com a expansão das ferrovias paulistas e a chegada da Estrada de Ferro Sorocabana (E.F.S.) à região oeste do estado, foram viabilizados o transporte rápido e barato para o café, a visita de compradores e negociantes de terras (figura 15), o 
transporte de mercadorias e bens de consumo e também a fixação de pessoas na região. A ferrovia "foi um fator marcante do progresso da região e, no caso particular de Presidente Prudente, o aparecimento e desenvolvimento da cidade ligaram-se estreitamente à Estrada de Ferro Sorocabana" (ABREU, 1972, p.38), que viria a se instalar em suas terras em 1919.

Figura 15 - Excerto de jornal que traz detalhes sobre a venda das terras na região de Presidente Prudente.

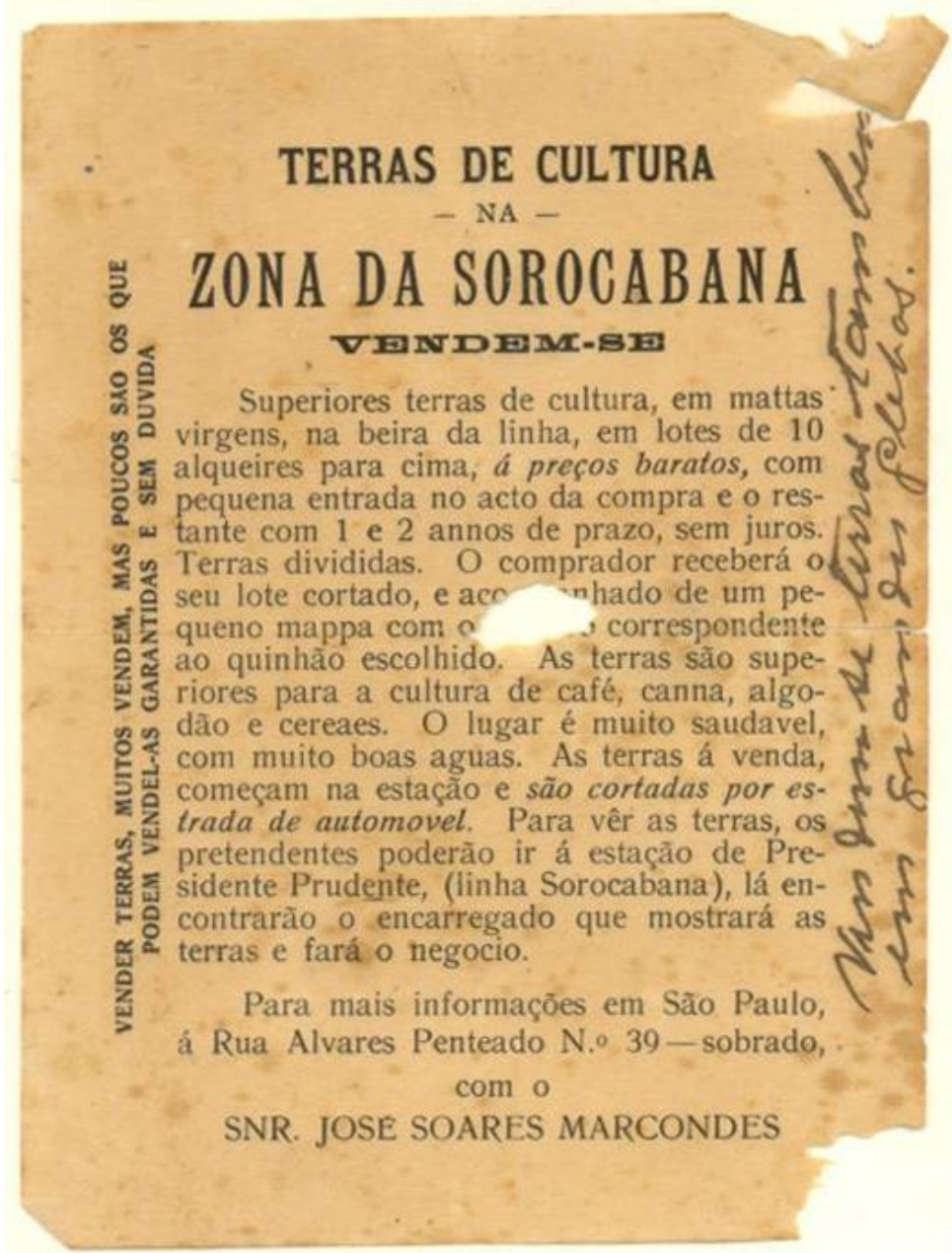

Fonte: acervo da família Marcondes; imagem disponível no Museu e Arquivo Histórico Antônio Sandoval Netto.

O surgimento das duas vilas que dão origem à cidade de Presidente Prudente está ligado à venda de terras - glebas - de duas fazendas: a Montalvão, de propriedade do Coronel José Soares Marcondes e a Pirapó - Santo Anastácio, de propriedade do Coronel Francisco de Paula Goulart. A partir da venda das terras nascia um núcleo urbano - Vila Goulart - que funcionava para dar suporte aos compradores de terras da região e que passou, com a chegada da ferrovia, a ser 
entreposto de produtos. Devido à concorrência pela venda de terras entre os coronéis, à margem oeste da linha férrea é criada pelo Coronel Marcondes o núcleo urbano Vila Marcondes.

Conforme relata Sposito (1995), o surgimento do núcleo urbano não ocorreu a partir do campo e da atividade agrícola, mas sim como um apoio para a comercialização das terras rurais e a expansão da ocupação sobre o oeste paulista.

Percebemos assim que, se a região fora em sua primeira fase ocupada através das posses de grandes glebas, ao tempo do surgimento das cidades, a terra já havia se transmudado em mercadoria, tanto assim que os núcleos urbanos nasciam para estear a sua comercialização. (Sposito, 1995, p. 5)

Segundo Abreu (1972), os dois coronéis associam-se, ainda em 1921, para pedir a criação de um distrito policial e no mesmo ano, é criado o município, envolvendo as duas vilas. $\mathrm{O}$ nome Presidente Prudente deriva de uma homenagem ao primeiro presidente civil do país e o primeiro eleito de maneira direta, Prudente de Moraes.

Com a ferrovia instalada no espigão das terras, ponto mais alto do terreno, divisor de águas, vê-se que a linha férrea funciona como um elemento divisório na cidade desde seu surgimento, separando as duas vilas - Goulart à esquerda e Marcondes à direita (figura 16). 
Figura 16 - Planta da cidade de Presidente Prudente, 1923.

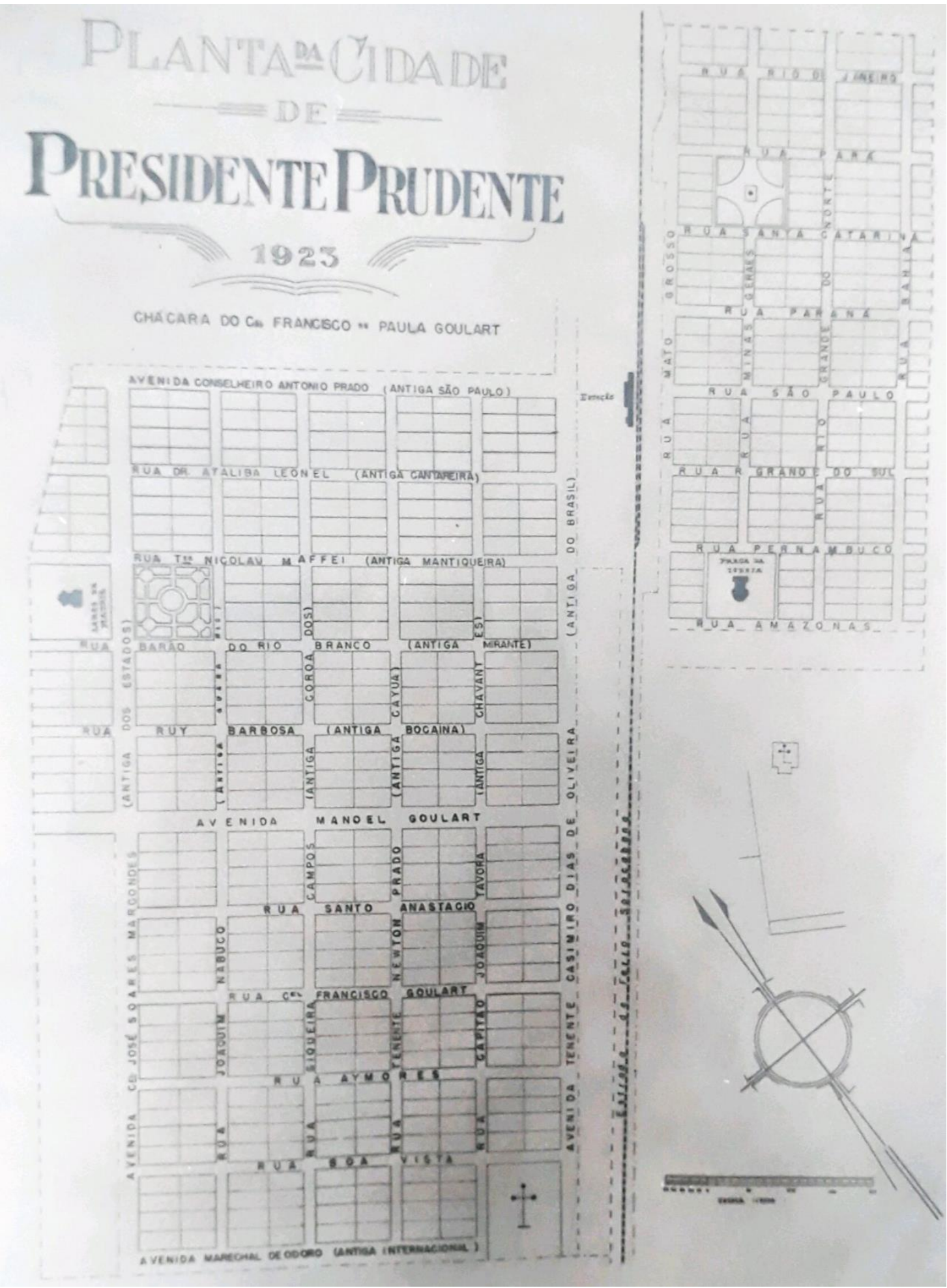

. Fonte: Abreu (1972, p.95).

Ainda em relação ao surgimento do núcleo urbano, pode-se afirmar que:

A evolução verificada no período inicial do desenvolvimento da Cidade (até 1923) revela já as tendências mais marcantes do processo de assentamento. Enquanto a vila Goulart se estende principalmente 
para o extremo sul, a Vila Marcondes cresce exatamente no sentido contrário. Ambos os sentidos de crescimento correspondem à procura das áreas mais aplainadas e alargadas do nível dos espigões e dos primeiros patamares contíguos a este. (Plano Diretor de Presidente Prudente, 1969, p.298).

$\mathrm{Na}$ Vila Goulart (figura 17), quatro avenidas paralelas e perpendiculares à linha férrea são abertas, configurando-se como o sistema principal de vias da cidade, articulando-se aos principais acessos e conectando a cidade aos distritos e municípios vizinhos. A Vila Marcondes (figura 18), a leste, depara-se, porém, com os obstáculos representados por um relevo abrupto, definido por talvegues e grandes fundos de vale, o que dificulta a implantação de um sistema viário, bem como a ocupação e conexão com outros pontos; como veremos adiante, o desenvolvimento da mancha urbana até os dias atuais está ligado diretamente a estas características, com o lado oeste da linha férrea apresentando um crescimento muito maior.

Além das questões ligadas à geomorfologia, segundo Abreu (1972), a vila Goulart recebeu maior destaque através de melhoramentos urbanísticos, como o projeto para a esplanada e praça da estação, e também na forma de legislações que previam isenção de impostos para construções de prédios em seu perímetro. Assim, por mais que a Vila Marcondes apresentasse uma importante rua comercial e terrenos legalizados, as questões relacionadas à qualidade do relevo, associadas ao fato da estação estar posicionada de frente à Vila Goulart fez com que esta recebesse diversos melhoramentos e adquirisse, no decorrer dos anos, um caráter maior de centralidade, o que ainda perdura. 
Figura 17 - Vila Goulart, a partir da estação, ainda sem a esplanada e praça da Bandeira (década de 1930).

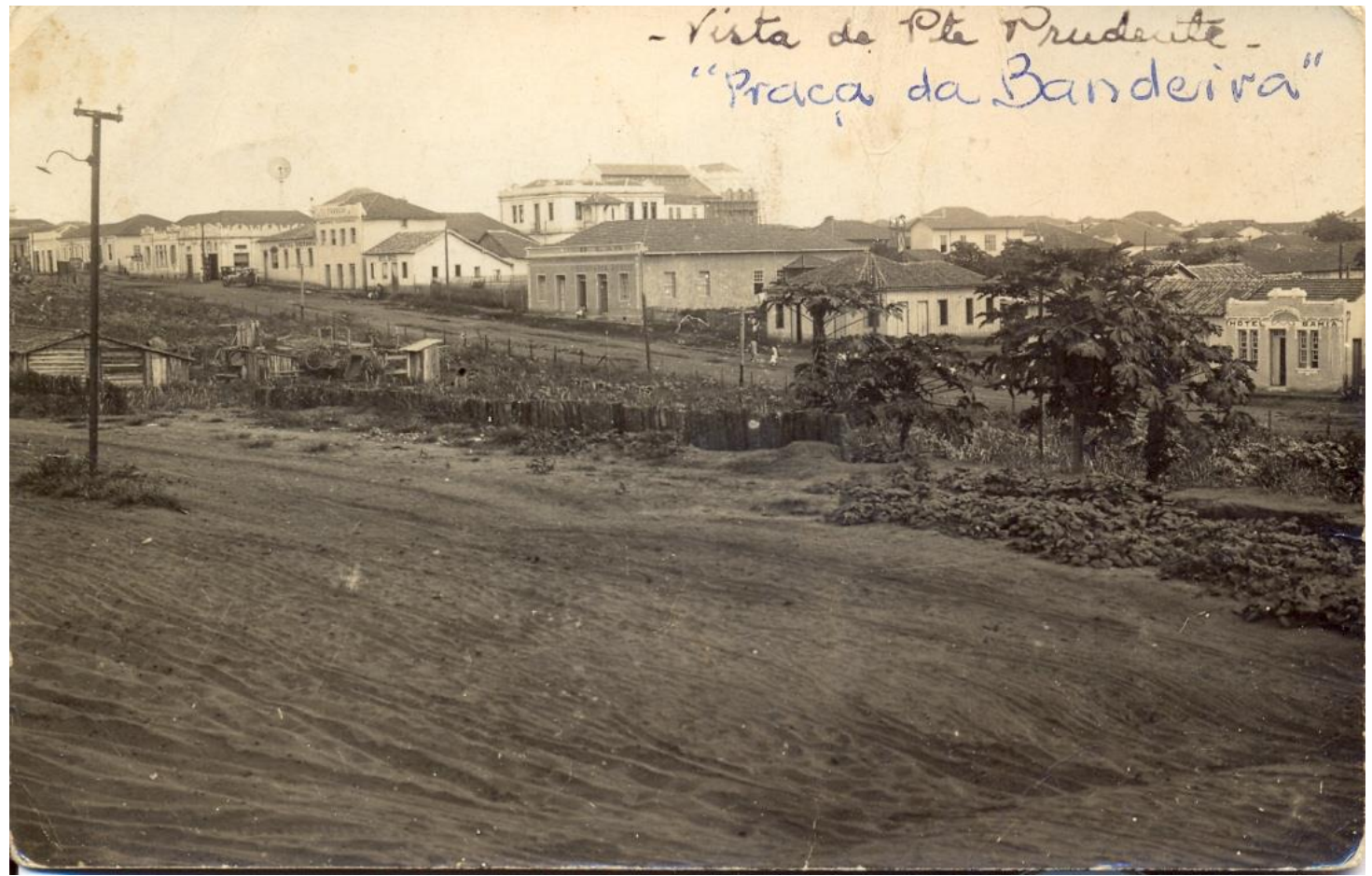

Fonte: Museu e Arquivo Histórico Antônio Sandoval Netto.

Figura 18 - Vila Marcondes - Rua Quintino Bocaiúva, principal via comercial (década de 1940).

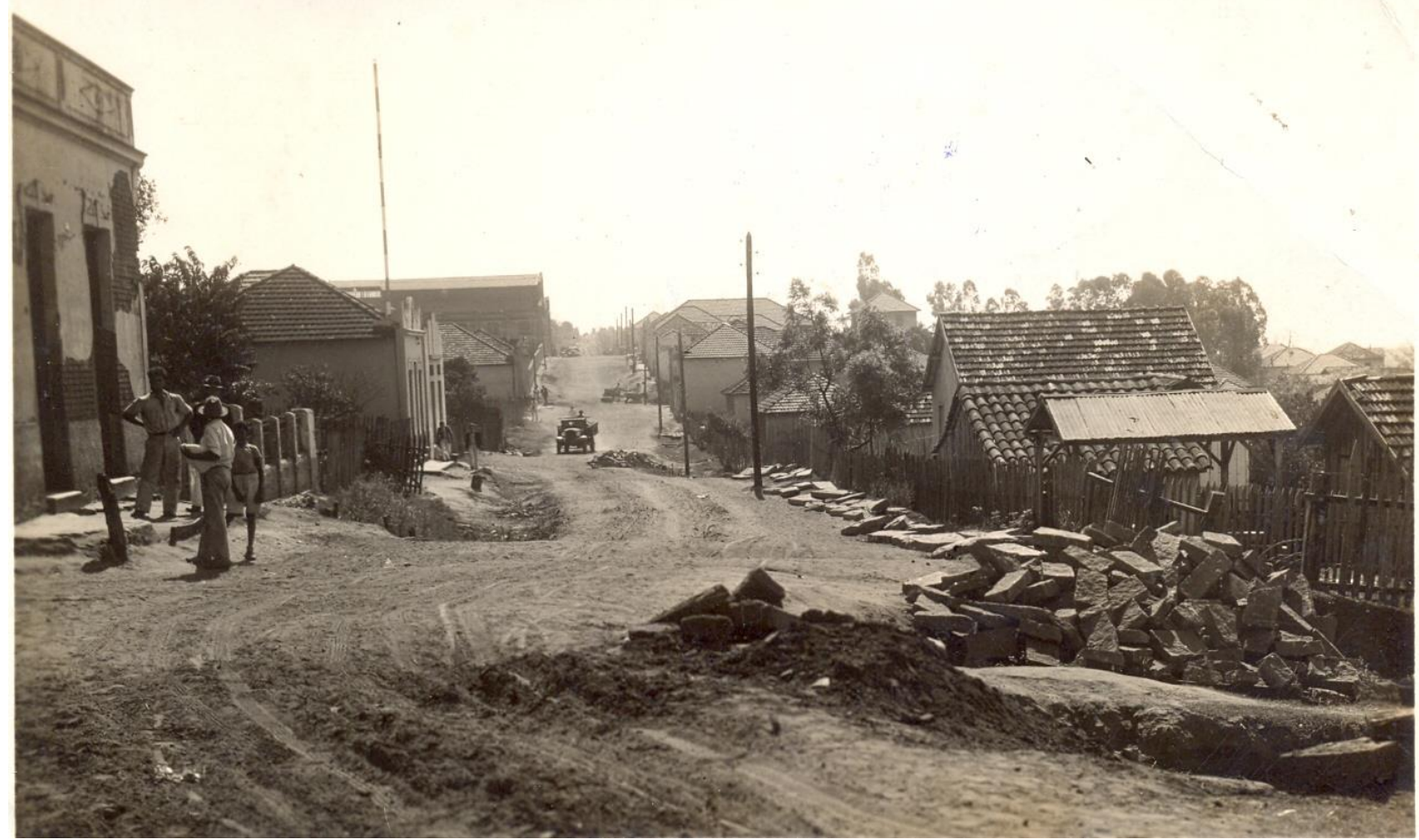

Fonte: Museu e Arquivo Histórico Antônio Sandoval Netto. 
Como relatam as análises do Plano Diretor realizadas pelo CPEU, em uma segunda fase (1923-1948) da evolução urbana (figura 19) nota-se, no sudoeste do quadrilátero, um padrão de traçado mais irregular, de caráter mais espontâneo e precário - termos descritos no Plano, seguindo a antiga estrada para Álvares Machado. A noroeste, percebe-se uma mudança de direção no traçado, definido por eixos longitudinais, em conformação com os patamares e linhas de drenagem. Entre 1949 e 1952 (terceira fase), dá-se a ocupação de todos os patamares entre os espigões por onde passa a linha férrea e o Córrego do Veado. Na última fase abordada pelo CPEU, (entre 1953 e 1967), o crescimento se dá para o Sul e Sudoeste, em direção à rodovia Raposo Tavares, em um início de transposição dos primeiros fundos de vale, compostos pelos córregos do Veado, Bacarin e Água Bôscoli.

Figura 19 - Evolução Urbana de Presidente Prudente (1917 a 1967).

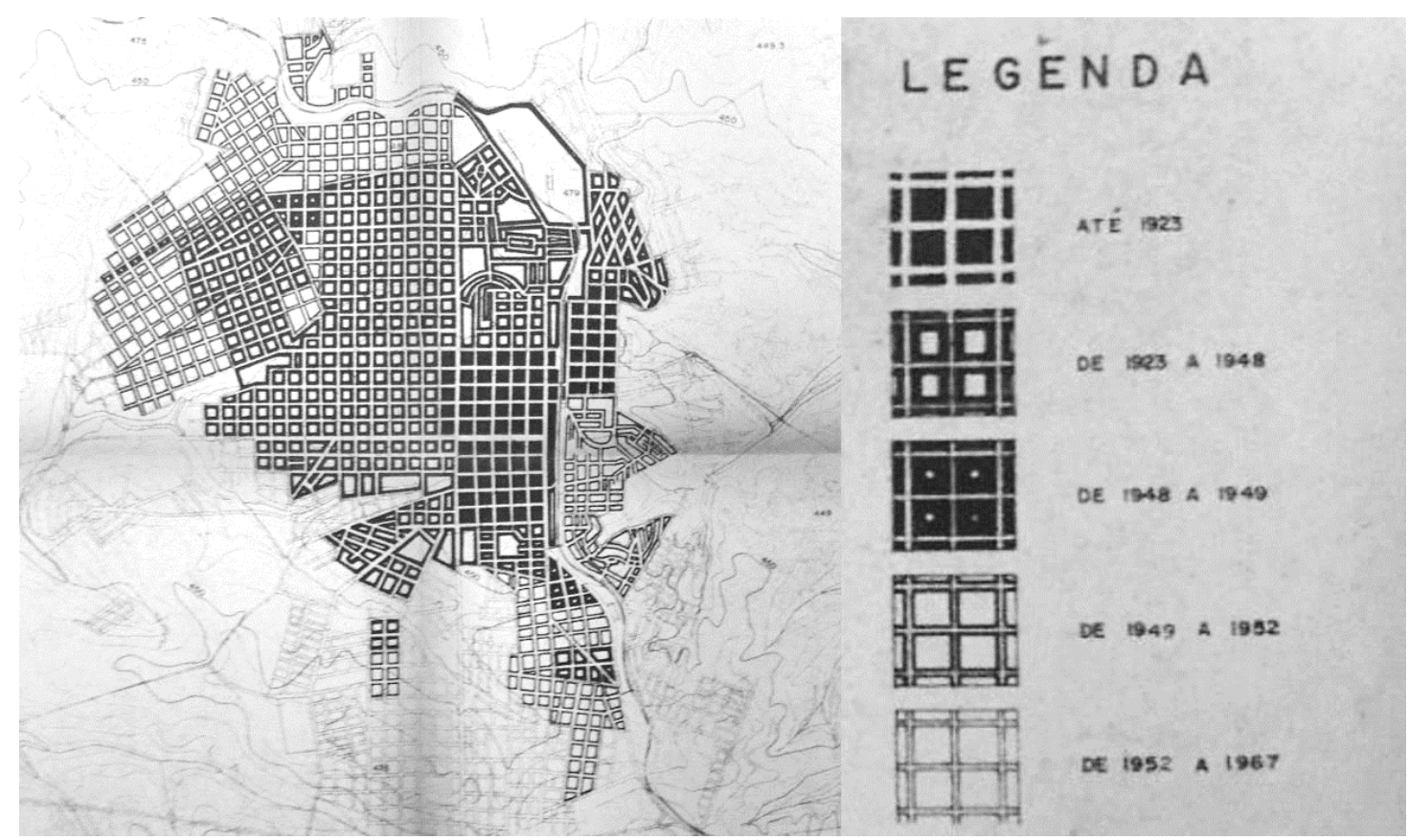

Fonte: Plano Diretor de Presidente Prudente (1969), prancha no 37.

A principal observação é que a evolução da mancha urbana se deu através da anexação de loteamentos às áreas já urbanizadas e que a implantação destes seguiu, geralmente, um traçado ortogonal, reticulado, que com frequência, ignorou o relevo como informação norteadora do traçado, bem como outros acidentes geográficos, promovendo grandes conflitos entre a implantação da malha, o relevo e os cursos d'água, principalmente nas baixadas (figura 20), em que os loteamentos apresentam o traçado mais irregular e descontínuo. 
Como relata Sposito (1995):

Na planta de Presidente Prudente de 1939 observamos que a cidade já começava a crescer tomando os espaços compreendidos pelos interflúvios entre o córrego do Bacarin e Água Boscoli, e entre esta e o Córrego do Veado. (SPOSITO,1995, p. 09).

Figura 20 - Vista parcial do centro de Presidente Prudente (1937), a partir do local da atual Santa Casa, na qual é possível observar que a cidade transpõe um dos primeiros fundos de vale. Neste caso, o do córrego Água Bôscoli.

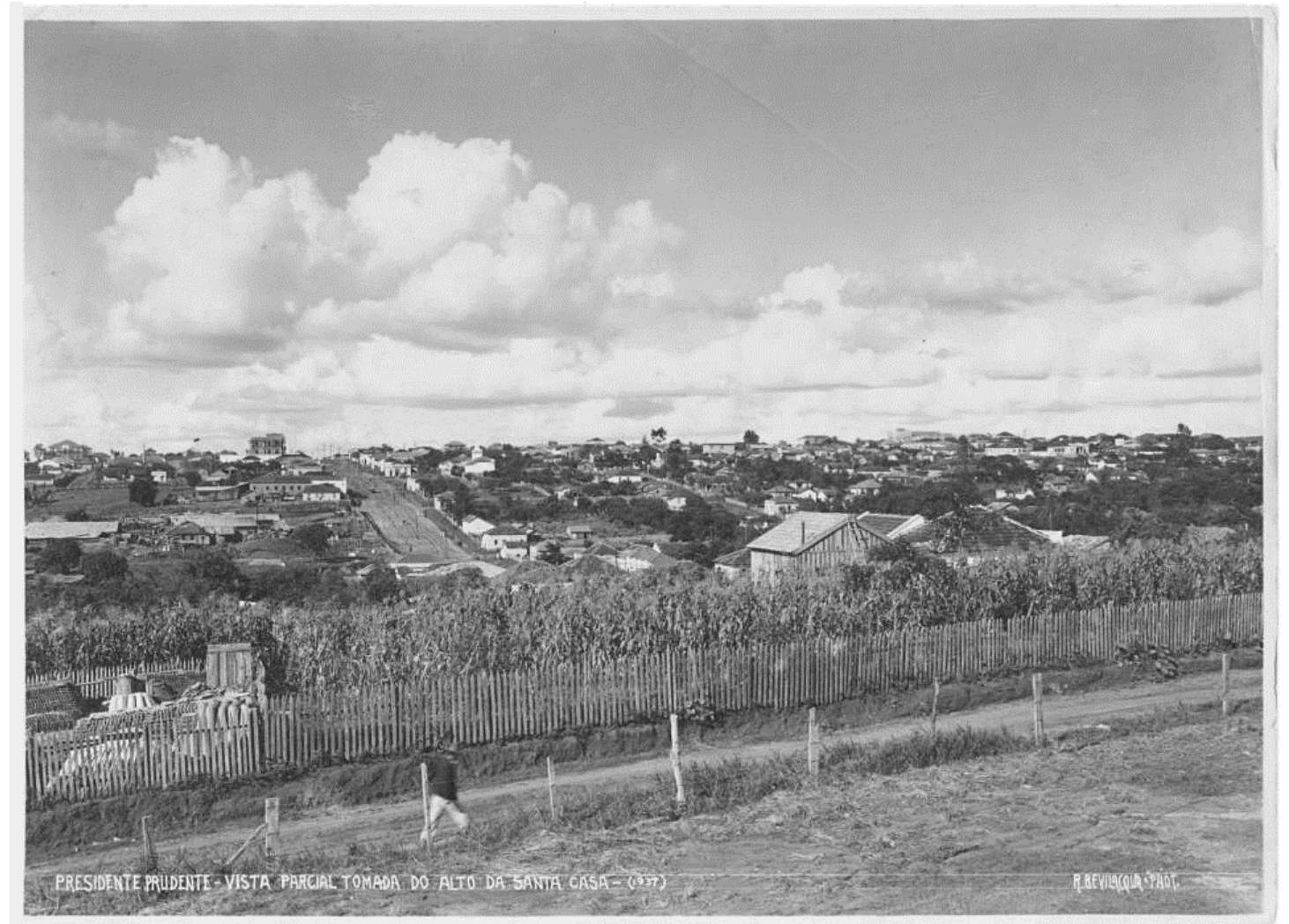

Fonte: Museu e Arquivo Histórico Antônio Sandoval Netto.

Ainda assim, caracterizava-se, nas análises do CPEU, a cidade de Presidente Prudente até os anos de 1950 "como um núcleo razoavelmente compacto, sem as deformações que usualmente acarreta a desenfreada especulação imobiliária" (Plano Diretor de Presidente Prudente, 1969, p.305).

Em relação ao planejamento municipal, o período até 1930 ficou definido, de acordo com Abreu (1972) pela falta de "atenção dos poderes públicos", na qual o núcleo urbano não recebeu investimentos e melhorias urbanísticas significativas.

A partir das décadas de 1940, 1950, segundo Sposito (1983), a cidade cresce, sua população aumenta, bem como os loteamentos, como é possível observar na imagem (figura 21), porém ainda sem planejamento consolidado e preocupações com 
regularização por parte do poder público. Nesta época, a vila Goulart já havia adquirido características e reconhecimento como área central.

Figura 21 - Presidente Prudente, 1939. Representação elaborada pela Companhia Elétrica Caiuá.

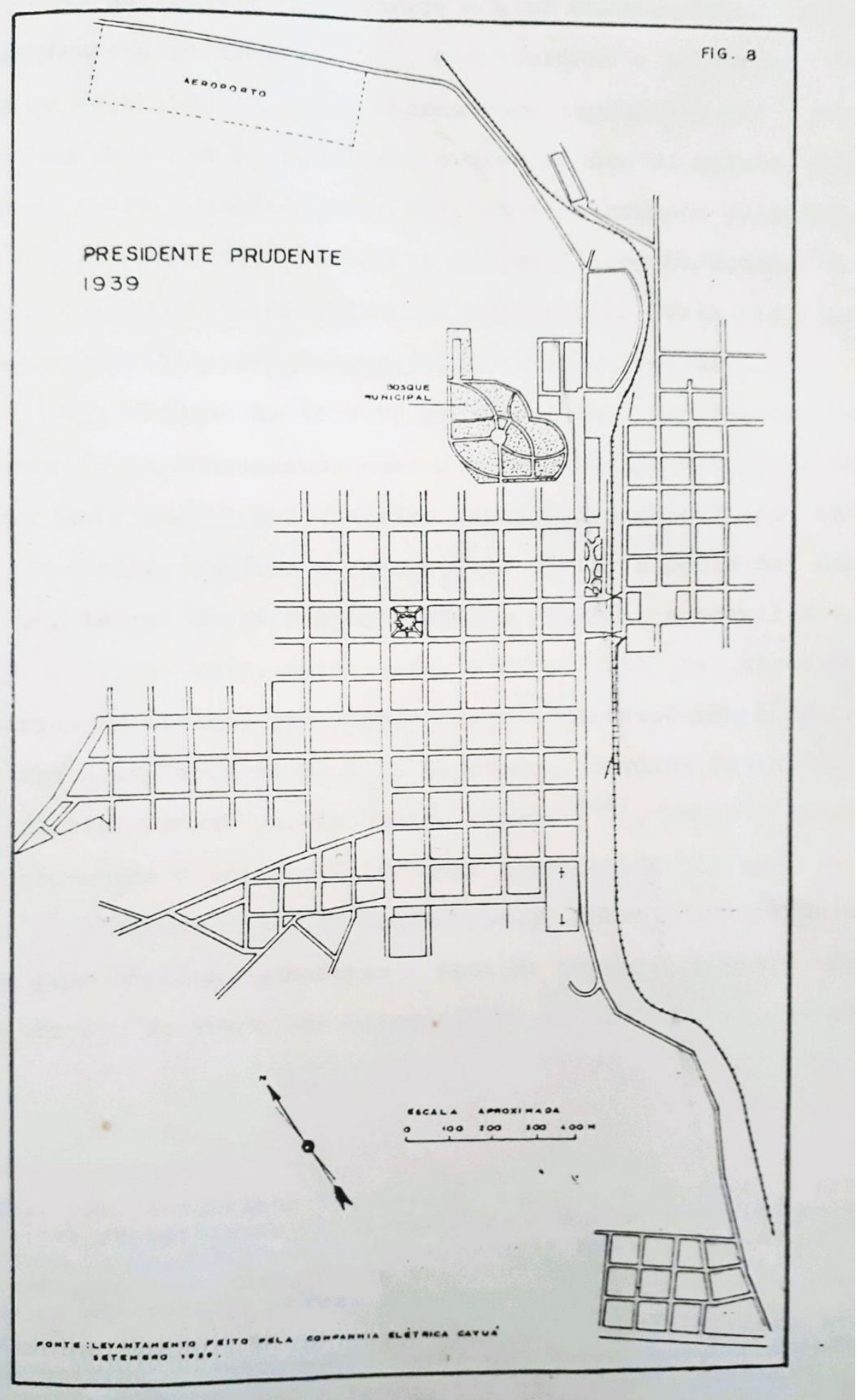

Fonte: Sposito (1983). 
Pela planta de Presidente Prudente de 1939 (figura 21), é possível perceber a configuração dos primeiros espaços livres da cidade, como as praças centrais (sendo que a Praça da Bandeira, localizada em frente à estação de trem, é atualmente ocupada por barracas e quiosques de comércio popular), o antigo cemitério (atualmente ocupado pela rodoviária) e o antigo Bosque Municipal.

\subsection{Histórico: décadas de 1960 e 1970 - polo regional de desenvolvimento e primeiro plano diretor}

Os períodos descritos no tópico anterior refletem ocorrências comuns a cidades do interior do Brasil, pautadas pela economia agrícola, população rural representativa, industrialização incipiente e ligada às matérias primas produzidas localmente e muitas vezes ligadas à exportação. Essa realidade estava distante das políticas de planejamento territorial dos grandes centros da época, aquele ligado ao embelezamento urbano, como o Plano Agache no Rio de Janeiro, ou do urbanismo sanitarista (ANDRADE, 1992), ou de remodelação urbana como o Plano de Avenidas de Prestes Maia, de 1930 (TOLEDO, 1996). Do mesmo modo, esses lugares permaneciam distantes das práticas de zoneamento e influências das unidades de vizinhança, características presentes nas capitais e grandes cidades brasileiras.

A partir das décadas de 1950 e 1960 é que se inicia certa mudança a nível municipal, uma vez que a Constituição de 1946 permite maior autonomia dos municípios, consagrando a ideia de planejamento governamental - iniciada na Era Vargas; o planejamento regional passa a fazer parte da agenda de interesses, como proposta para fixação do homem no campo e dinamização da economia no interior do Brasil, especialmente nas regiões Nordeste e Amazônica, bem como nos estados ligados ao Rio São Francisco e ao aproveitamento do seu potencial econômico. Nesse contexto surge a Comissão Interestadual da Bacia Paraná-Uruguai (CIBPU), que mobilizará o planejamento municipal em Presidente Prudente a partir de sua escolha para implantação de um projeto de Distrito de Industrial, visando ao desenvolvimento industrial e consagrando-a como polo de desenvolvimento regional.

A década de 1960 representou uma nova fase no planejamento das cidades, com uma perspectiva mais abrangente, que passou a considerar seus diversos aspectos formadores - sociais, econômicos, físicos e institucionais; desta visão é que surgiram os Planos Diretores de Desenvolvimento Integrado (PDDI); ao mesmo 
tempo, o período ficou marcado pelo centralismo e autoritarismo do regime militar, que passou a ter o controle sobre os recursos repassados aos Estados e Municípios.

A institucionalização do planejamento se deu a partir da criação do Serviço Federal de Habitação e Urbanismo (SERFHAU), Lei no 4380/1964 e regulamentado pelo Decreto n59917/1966, que passou a gerenciar a elaboração do "Plano de Desenvolvimento Local Integrado" para os municípios, financiado pelo FIPLAN (Fundo de Financiamento de Planos), órgão criado dentro do Banco Nacional da Habitação (BNH).

A aprovação da Lei Orgânica dos Municípios, Lei estadual n 9842/1967, estabelecendo a obrigatoriedade do Plano Diretor de Desenvolvimento Integrado para os municípios como condição para obtenção de empréstimos juntos ao governo federal (SERFHAU) e estadual, provocou um ciclo de elaboração de planos diretores, que podiam ser elaborados por escritórios particulares de consultoria e financiados através do FIPLAN, ou elaborados por órgãos como o CPEU (Centro de Pesquisa e Estudos Urbanísticos), da Faculdade de Arquitetura e Urbanismo da Universidade de São Paulo (FAU-USP).

O tópico seguinte analisa dois documentos - planos - produzidos na década de 1960 para a cidade de Presidente Prudente - SP e que representam processos de planejamento responsáveis por fundamentar uma regionalização do município como capital do oeste paulista - processos estes, à soma de outros fatores, que a levaram a ser contextualizada e reconhecida também como cidade média.

Os documentos são: o Projeto de um Distrito Industrial e o Plano Diretor de Presidente Prudente, ambos realizados pelo Centro de Pesquisas e Estudos Urbanísticos da Faculdade de Arquitetura e Urbanismo da Universidade de São Paulo (CPEU), o primeiro a pedido da CIBPU e o segundo como consequência deste, em parceria com a Prefeitura Municipal.

\subsubsection{CIBPU: Projeto de um Distrito Industrial (1966/1968)}

A Comissão Interestadual da Bacia Paraná-Uruguai (CIBPU), criada em 1951, foi uma experiência de planejamento regional centrada no desenvolvimento de bacias hidrográficas, baseada no modelo norte-americano para o planejamento do vale do rio Tennessee (TVA) (GARDIN, 2009), formada pelos estados componentes da bacia 
do rio Paraná (Mato Grosso, Goiás, Minas Gerais, São Paulo e Santa Catarina) e o Rio Grande do Sul, concentrando também a bacia do rio Uruguai.

A CIBPU surgiu nesse contexto em que o pensamento predominante era o de que, por meio do planejamento regional, poder-se-ia suprir o Brasil de meios de superação das carências infraestruturais existentes, para, e somente a partir daí, impulsionar-se o tão desejado processo de industrialização nacional. (GARDIN, 2009, p. 20).

Assim, foi responsável pelo levantamento, análise e sugestão de diversas obras ligadas à produção de energia elétrica e navegação fluvial. Ainda segundo Gardin (2009), foi influenciada pelas ideias do Padre Lebret de desenvolvimento econômico e melhoria das condições de vida da população e, posteriormente, pela teoria dos polos de desenvolvimento de Perroux, propondo um plano de industrialização regional, o que culmina com a demanda ao CPEU de um Projeto de Distrito Industrial para a cidade de Presidente Prudente.

$\mathrm{O}$ trabalho em questão teve como objetivo elaborar um projeto de distrito industrial como forma de fixar a atividade econômica regional através da noção de Polo de Desenvolvimento (polarização), concentrando em certos centros urbanos, já dotados de infraestrutura mínima, certa quantidade de indústrias que dinamizassem a economia, gerando empregos e fixando população.

[...] em cada Estado, os estudos delimitaram certas áreas (que consistem em determinados grupos de municípios), com características especiais, um centro polarizador das principais atividades econômicas e sociais e o espaço diretamente sob a sua influência.

No confronto destas áreas, procurou-se selecionar aquelas que vinham crescendo a taxas mais elevadas do que as demais, no pressuposto, de que uma vez introduzidos novos incentivos, aquela tendência mais facilmente se aceleraria. (Projeto de um Distrito Industrial para Presidente Prudente, 1966, p.13)

A escolha foi baseada na análise de áreas selecionadas dentre os sete estados pertencentes à CIBPU e Presidente Prudente foi selecionada por ser um polo de desenvolvimento do Oeste Paulista; assim, o distrito industrial de Presidente Prudente, idealizado em 1966, foi um projeto piloto estabelecido por meio do Plano de Industrialização Regional, através de uma parceria entre a CIBPU, o CPEU e a Prefeitura Municipal de Presidente Prudente.

O documento final, uma monografia disponível no acervo da Biblioteca da Faculdade de Arquitetura e Urbanismo FAU-USP, apresenta-se dividido em nove capítulos, apresentando a experiência internacional no projeto e execução de distritos 
industriais, com ênfase para a experiência inglesa - as Cidades Novas e os conceitos das unidades de vizinhança - que influenciará fortemente o projeto proposto para Presidente Prudente.

Entre as razões para o surgimento de distritos industriais no interior do estado de São Paulo são destacadas no Projeto de um Distrito Industrial para Presidente Prudente (1966, p.93):

a) Demografia e urbanização: o aumento das populações urbanas demanda novos postos de trabalho;

b) Modificações no setor agrícola: mão-de-obra livre no campo, dirige-se aos centros à procura de emprego (que deverá ser criado), justificando a industrialização regional;

c) O fenômeno paulistano: "a intensa urbanização do interior, sem a criação de novas oportunidades de trabalho, começa a provocar uma situação de desequilíbrio, agravando as diferenças de níveis de renda entre estas regiões."

d) O processo de industrialização: descentralização aumentaria o poder aquisitivo da população no interior do país;

e) Navegação fluvial: aproveitamento do potencial navegável dos rios;

f) Energia: os rios que delimitam o Oeste Paulista são os que apresentam maior potencial hidrelétrico;

g) Conclusão: distrito industrial como forma de desenvolvimento regional.

A escolha final de Presidente Prudente se dá por sua influência regional: grande eixo ferroviário, além de estradas conectando o norte do estado de São Paulo, o Mato Grosso, (que à época reunia os estados de Mato Grosso e Mato Grosso do Sul atuais), e também o norte do Paraná; possui alta renda per capita, região rica em materiais primas, além de rios com o maior potencial hidrelétrico. A industrialização verificada no município é menor quando comparada a outros municípios do interior, mas seu crescimento registrado e evolução dinâmica foram maiores. Assim, "foi escolhida a região de Presidente Prudente como a sede da primeira experiência de um programa de desenvolvimento acelerado com base na industrialização regional" (Projeto de um Distrito Industrial para Presidente Prudente, CIBPU, p.104).

Para escolha das áreas possíveis para o distrito industrial, precisou-se analisar a cidade como um todo, visto que não possuía Plano Diretor. Assim, o CPEU desenvolveu estudos e análises "como parte integrante do processo de zoneamento urbano", realizando hipóteses sobre o desenvolvimento da cidade e traçando as principais diretrizes de organização urbana. As análises e proposições realizadas, 
mesmo que o distrito não tenha sido executado de maneira fiel ao projeto, influenciaram o poder público municipal em outras questões de planejamento.

Os levantamentos básicos realizados foram: sistema topográfico, serviços públicos básicos, rede de água, rede de esgoto, rede de eletricidade, pavimentação e vias regionais, usos e densidades do solo; e as diretrizes de organização urbana foram: zoneamento, sistema viário, densidades demográficas e diretrizes de organização e de expansão urbana.

A partir das análises das indústrias presentes até então na cidade, bem como das densidades urbanas, orientou-se a criação de um novo eixo central correspondendo ao Córrego do Veado, porém referenciado no documento sempre como "fundo de vale" - que conectaria os dois distritos industriais propostos: o Distrito Industrial Diversificado e o Distrito Industrial Especializado - este com base nas indústrias já existentes de processamento animal, como frigoríficos e curtumes. As diretrizes de organização urbana são apresentadas na figura 22.

A escolha do local dos distritos se fez através da carta de declividades, bem como pela influência dos ventos dominantes. Assim, o distrito industrial especializado está próximo ao emissário, área que já concentrava indústrias (frigoríficos), destinada à implantação em layout vertical; "Distrito industrial especializado para a indústria da carne". O distrito industrial diversificado está em uma área de entroncamento ferroviário e rodoviário, apresenta declividade dentro dos limites, boa posição com relação aos ventos e está fora da área de expansão habitacional proposta. 
Figura 22 - Diretrizes de Organização Urbana para Presidente Prudente, com demarcação dos distritos/usos propostos. O fundo de vale do Córrego do Veado, em azul, aparece descrito na legenda como "faixa central".

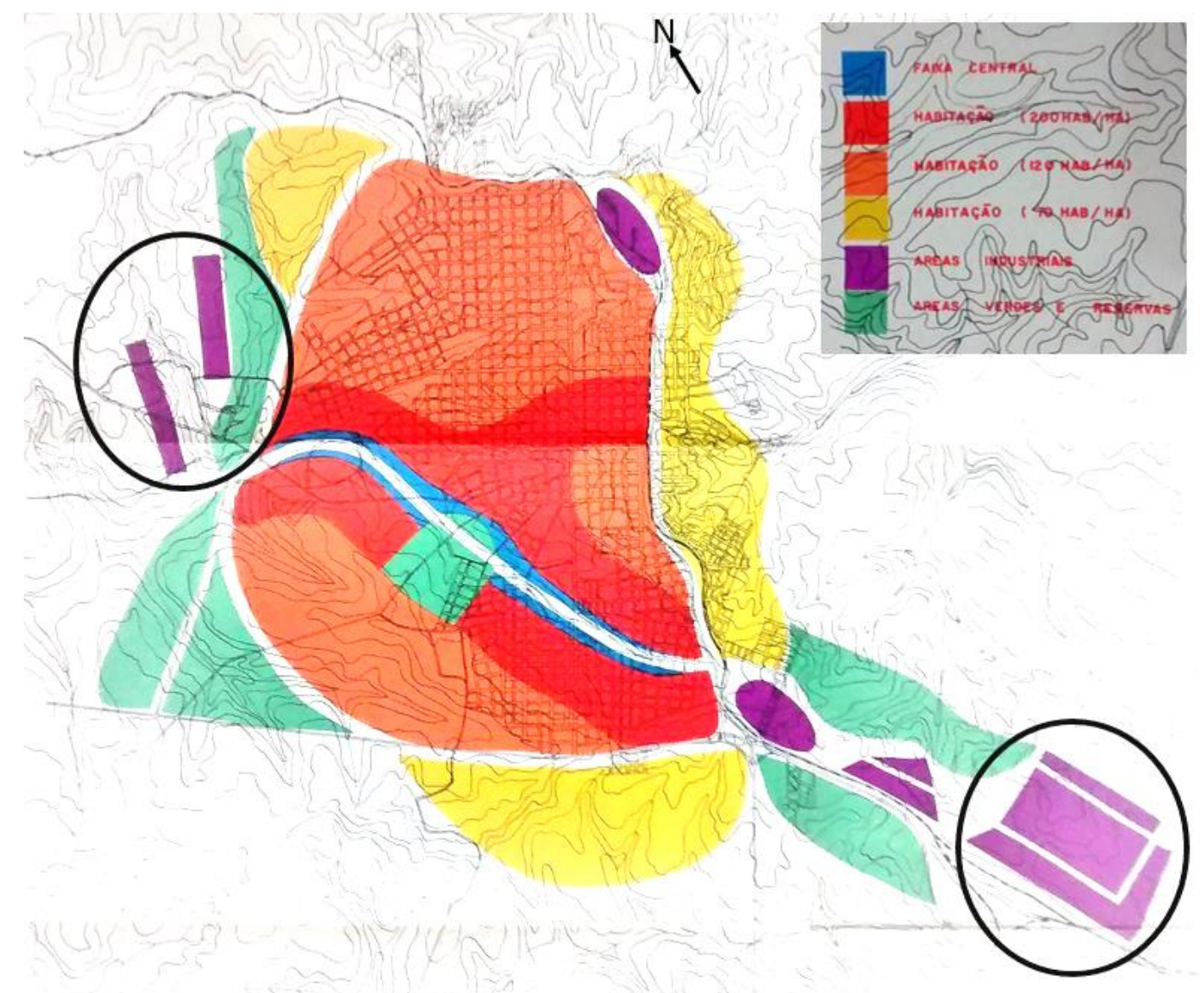

Fonte: Projeto de um Distrito Industrial para Presidente Prudente (1966), modificado pelo autor.

Com relação ao projeto dos distritos, o que merece destaque é a incorporação de alguns conceitos da unidade de vizinhança, como a valorização dos caminhos de pedestres e áreas verdes. Assim, o projeto para os distritos apresenta ruas e travessas exclusivas para esses (figura 23), conectando os lotes industriais pelo miolo das quadras, distante do fluxo de veículos e cargas das vias comuns, que estão no entorno dos empreendimentos. 
Figura 23 - Distrito Industrial Diversificado, localizado a sudeste da mancha urbana, com destaque para os jardins/áreas verdes e caminhos exclusivos para pedestres.

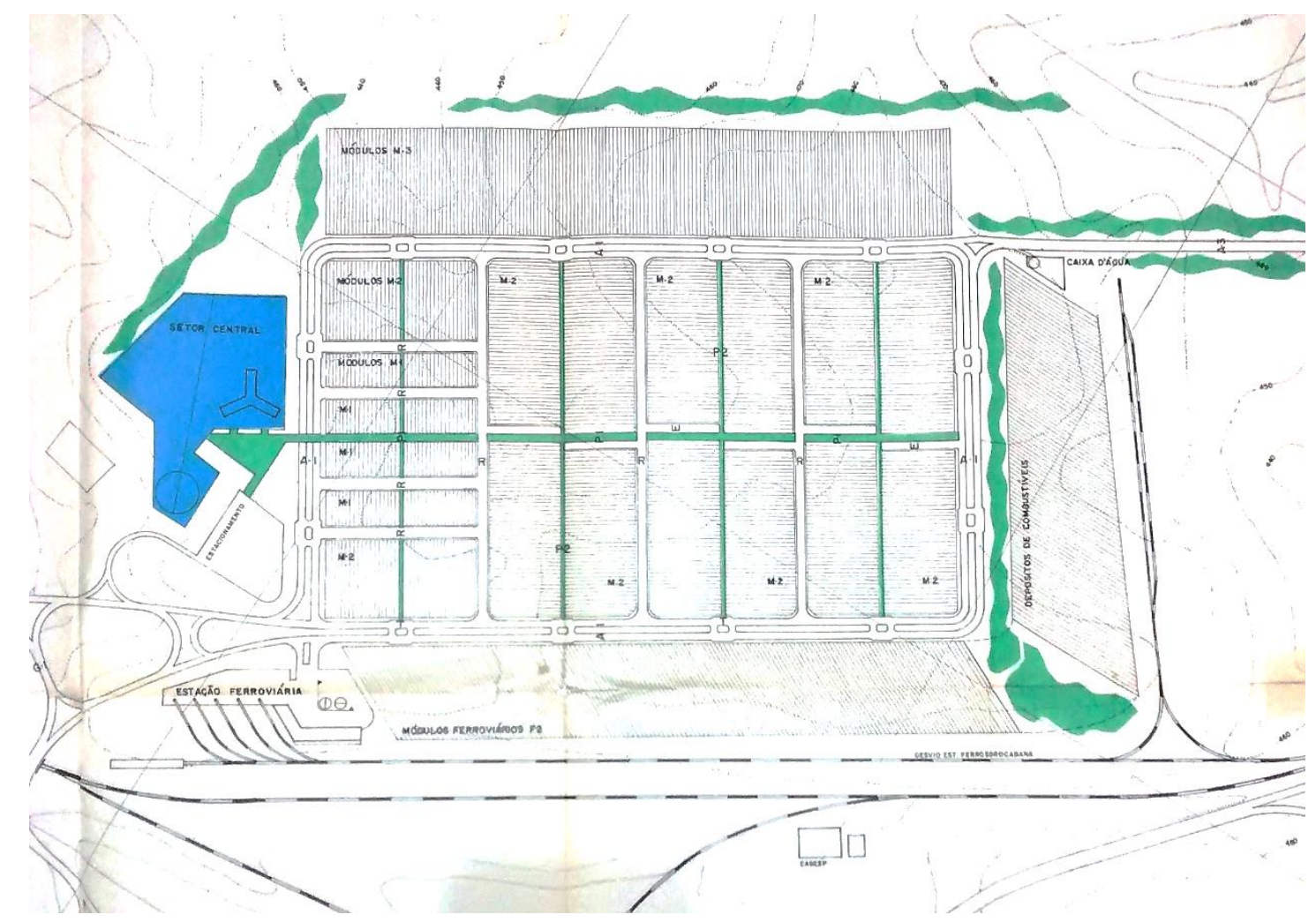

Fonte: Projeto de um Distrito Industrial para Presidente Prudente (1966).

Uma das proposições que mais nos interessa nas diretrizes de organização urbana está na página 113 do trabalho, abordando a construção de uma faixa central (ainda na figura 22) conectando os distritos industriais propostos:

Se ocuparmos os terrenos disponíveis com as áreas previstas para a expansão da cidade, verificaremos que ficará demarcado um eixo de simetria em relação ao conjunto da área urbana. Geograficamente esse eixo é o fundo de vale que hoje, mais ou menos, delimita a área mais densamente ocupada da cidade no seu lado sul e de desenvolve na direção leste-oeste. Este fundo do vale está ainda em sua quase totalidade desocupado. Propõe-se que seja construído sobre ele uma avenida central e ao longo dela se desenvolva 0 futuro centro de Presidente Prudente. Nas extremidades desta avenida, acham-se as duas áreas mais indicadas para a instalação de distritos industriais. (Projeto de um Distrito Industrial para Presidente Prudente, 1966, p.113, grifo nosso)

Ainda sobre o destacado "futuro centro de Presidente Prudente":

A municipalidade deverá promover a transferência do futuro centro, incentivando o surgimento de atividades comerciais e culturais, dentro das normas que deverão ser estabelecidas pelo plano diretor da cidade. (Projeto de um Distrito Industrial para Presidente Prudente, 1966, p.119) 
Em relação às áreas verdes e espaços livres, a diretriz de organização urbana ainda propõe:

O critério para distribuição das áreas verdes da cidade não deve ser o da criação de inúmeras praças isoladas dentro da área construída, mas de faixas verdes, bem sombreadas, que serviriam para a caminhada dos pedestres. Deixarão assim de servir apenas para a permanência das pessoas, mas passando a ter uma função mais orgânica e ativa no conjunto da cidade, junto às quais se instalariam os equipamentos urbanos. Poder-se-á reduzir, desta forma, ao máximo as áreas verdes, concentrando-se as áreas habitacionais. Seriam reservados grandes espaços verdes apenas para as áreas ocupadas pelas escolas, nas unidades de vizinhança, e para o centro esportivo e recreativo, este último junto à avenida central.

As áreas de contorno urbano adquiriam, então, importância no tratamento paisagístico da cidade, que seria concebida segundo o novo conceito que preceitua: "em vez de cidades jardins cidades implantadas no meio de um grande jardim". (Projeto de um Distrito Industrial para Presidente Prudente, 1966, p. 120, grifo nosso)

Comparando o projeto para os distritos e as propostas de organização urbana, observa-se a influência que este estudo teve no planejamento posterior e nas políticas públicas de desenvolvimento do município. Por mais que o distrito industrial diversificado não tenha sido construído fielmente ao projeto, devido a impasses na questão da área de assentamento, que era de propriedade da FEPASA e precisaria, para ser consolidada, ser transferida ao município, (GARDIM, 2009), e as vias de pedestre jamais tenham sido executadas, um projeto de implantação por uma empresa privada foi realizado, próximo à localização proposta e com desenho das vias e quadras semelhante ao projeto desenvolvido pelo CPEU para a CIBPU (figura 24). 
Figura 24 - Distrito industrial proposto (à esquerda) e executado posteriormente (à direita).

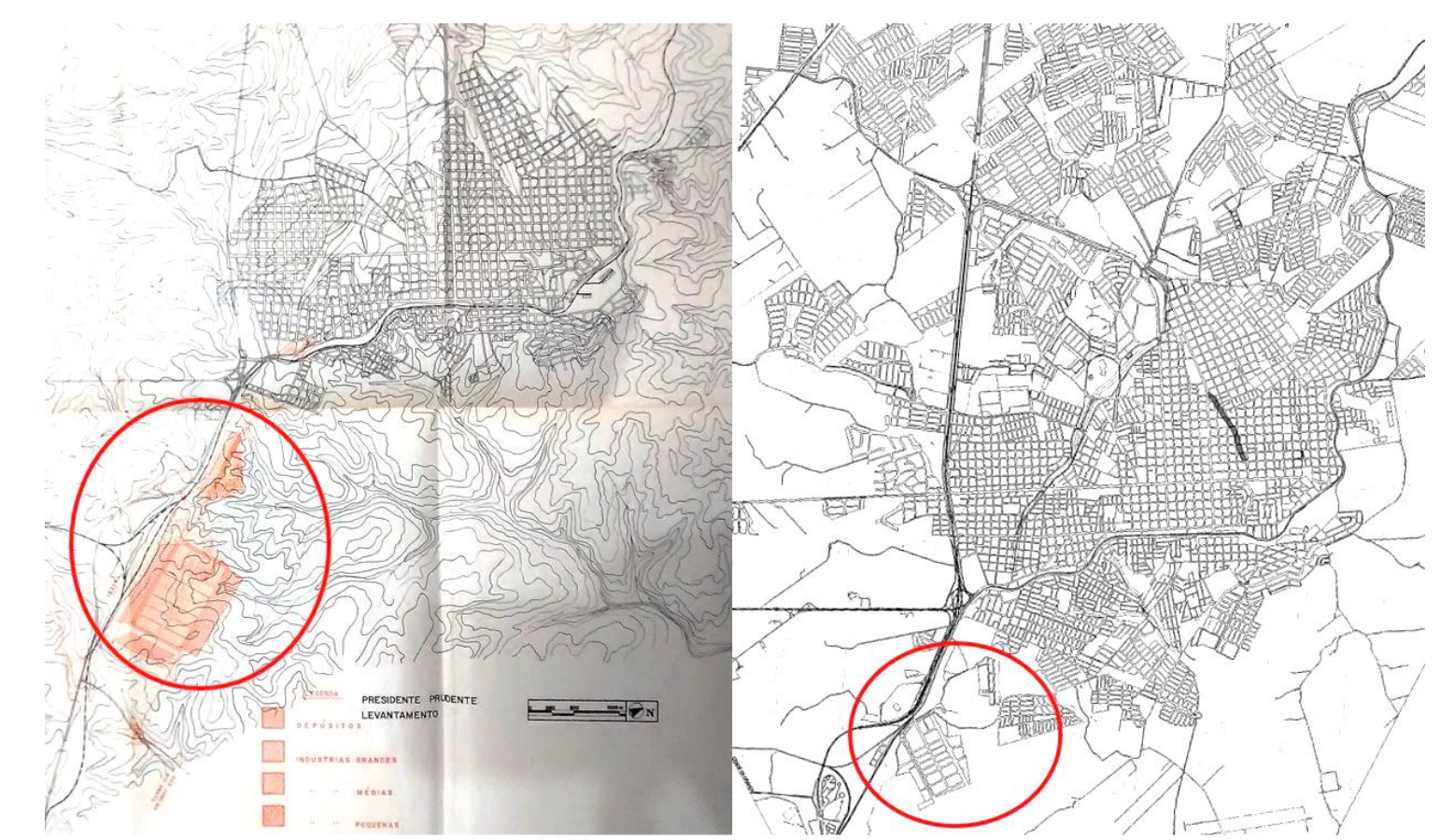

Fonte: Projeto de um Distrito Industrial para Presidente Prudente (1966) e Prefeitura Municipal de Presidente Prudente (2010), modificado pelo autor.

Como relatado, o distrito especializado não chegou a ser executado, permanecendo no local apenas as empresas frigoríficas e de processamento de derivados já existentes; algumas permanecem até os dias atuais, tornando-se fonte de mau cheiro para diversos bairros do entorno, visto que a malha urbana se expandiu consideravelmente naquela direção.

Com relação às proposições da construção de uma avenida central - com duas pistas sobre o fundo de vale, constituindo-se em um novo centro, com atividades comerciais e culturais - e junto dela um centro esportivo e recreativo, verifica-se que a diretriz foi seguida pela prefeitura municipal, que implantou, no decorrer da década de 1970, ao longo do fundo de vale as avenidas 14 de Setembro - à época de sua abertura denominada de Pista Norte - e 11 de Maio - à época de sua inauguração denominada de Pista Sul - (figura 25), canalizou o córrego e construiu, entre as avenidas Brasil e Manoel Goulart, o Parque do Povo (figura 25) hoje principal área de lazer, recreação e esportes da cidade, concentrando comércio e serviços, além de investimentos imobiliários de grande porte e valor (figura 26), constituindo-se como uma das áreas mais valorizadas de Presidente Prudente, constituindo-se na planejada nova centralidade. No local proposto para o centro esportivo, foi implantando o Centro 
Olímpico (figura 25), que concentra piscinas, quadras poliesportivas e campo de futebol, funcionando como um centro de aulas e treinamento.

Figura 25 - Ocupação do fundo de vale do Córrego do Veado (o córrego está representado pela linha pontilhada).

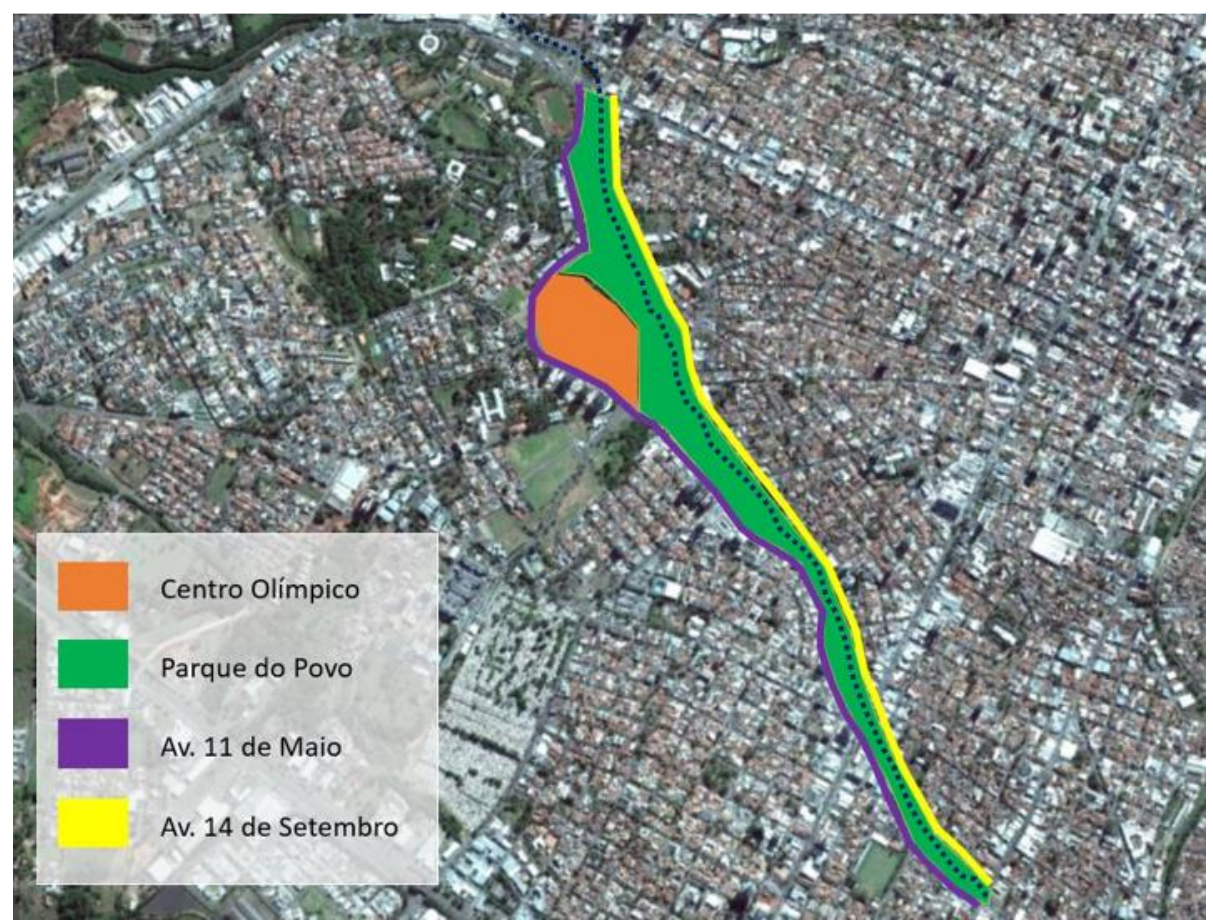

Fonte: Google Earth (2017), modificado pelo autor.

Figura 26 - Trecho do Parque do Povo, Presidente Prudente.

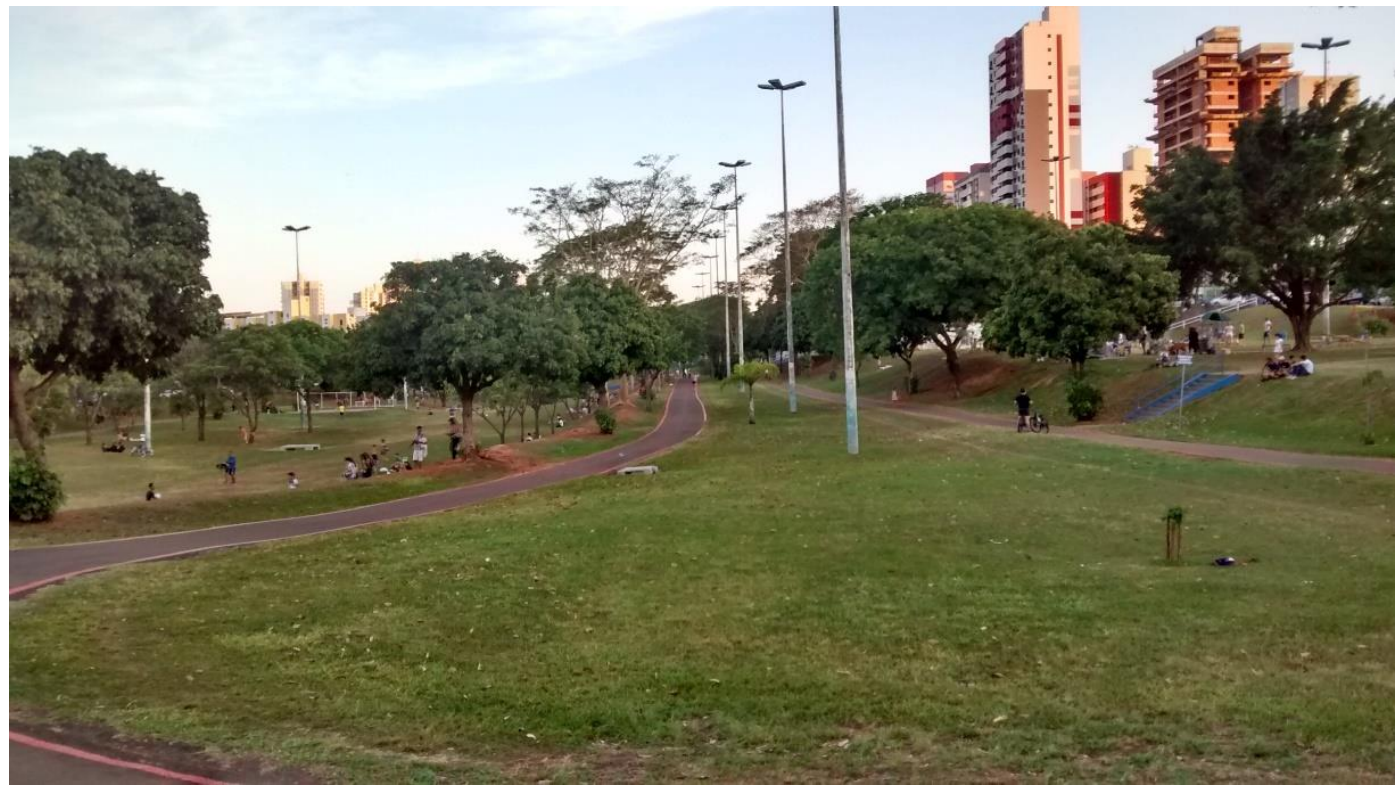

Fonte: arquivo do autor, 2015. 
Em relação ao Parque do Povo:

Tal espaço público nasceu do processo de urbanização e canalização do trecho inicial do Córrego do Veado. A Prefeitura Municipal apresentou à população, em 1976, o lançamento do Projeto denominado "Fundo de Vale", justificando a necessidade da realização de um processo de reurbanização do fundo de vale, o qual se apresentava como um entrave ao desenvolvimento da cidade.

Silva (1994) elucida que havia a necessidade da melhoria do saneamento e do sistema viário - o qual, segundo a equipe de elaboração do Plano Diretor de Presidente Prudente, em 1968, não contribuía para a expansão territorial da cidade - sendo também considerados como argumentos para a realização da obra.

A fonte de recursos para o início da implementação do projeto adveio do F.D.U. (Fundo de Desenvolvimento Urbano) e do D.N.O.S. (Departamento Nacional de Obras e Saneamento). A partir de 1977, recursos oriundos do Programa CURA (Comunidade Urbana para Recuperação Acelerada) passaram a financiar o projeto. (BORTOLO, 2013, p.61-62)

\subsubsection{CPEU: Plano Diretor de Presidente Prudente (1968/1969)}

O Centro de Pesquisa e Estudos Urbanísticos (CPEU), criado junto à Cátedra de Urbanismo da Faculdade de Arquitetura e Urbanismo da Universidade de São Paulo (FAU-USP), através da lei oㅡ 3233, de 27 de outubro de 1955, tinha a finalidade de aprimorar os conhecimentos, bem como o ensino e aprendizado do planejamento territorial.

O CPEU se destinava a realizar estudos básicos para o planejamento territorial, organizar planos diretores para os municípios que o desejassem e a realizar pesquisas preliminares à execução de planos diretores.

Segundo Birkholz (1964):

Podemos definir Plano Diretor Municipal como a organização dos espaços, atividades e funções de um município, compreendendo as áreas urbanas e de expansão urbana, assim como as áreas rurais do município, levando em conta os fatores físicos, econômicos, sociais e político-administrativos, para alcançar o bem-estar progressivo dessa coletividade. (BIRKHOLZ, 1964, p. 13).

O processo de planejamento territorial pelo CPEU, segundo Birkholz (1964), seguia uma metodologia baseada em três fases: Fase de Eclosão (assinatura de convênio entre prefeitura e CPEU, definindo uma comissão técnica local, que funcionaria como órgão de planejamento no município, ou contratação de um escritório particular para elaboração do plano), Fase do Projeto (com delimitação da unidade - considerando sempre o município como totalidade; a primeira visita ao local 
por parte dos técnicos; inquérito bibliográfico e monográfico, com representações gráficas para melhor análise e síntese; trabalho em equipe; etapas de análise; e composição do Plano Diretor através de síntese) e, por último, Fase de Execução.

As pranchas de análise e síntese, consideradas básicas, dividiam-se em Elementos Naturais (geográficos, geológicos e climatológicos) e Elementos Humanos (evolução quantitativa e qualitativa da população; atividades: indústria, comércio, artesanato; vida econômica: abastecimento, localização dos edifícios; comunicações: transportes, tráfego, vias urbanas, transportes coletivos; funções da aglomeração; serviços públicos: rede de água, esgoto, galerias, eletricidade, calçamento; ensino e saúde: estabelecimentos de ensino e de saúde, além daqueles ligados à recreação e lazer; residências: características dos imóveis; espaços livres: áreas verdes púbicas e parques; monumentos históricos; zonas de influência; área urbana: perímetro; legislação e finanças públicas).

"O Plano Diretor Municipal se compõe dos seguintes elementos: quatro sistemas gerais, problemas específicos de desenvolvimento local e organização comunitária" (BIRKHOLZ, 1964, p. 41). Sendo assim, vai tratar sobre o sistema de vias principais, zoneamento - propondo uma prancha com as áreas funcionais e uso especializado do solo, e espaços livres verdes ou sistema de recreio.

O problema do recreio está diretamente ligado ao problema mais
difícil do planejamento territorial que é não construir, deixar
espaços livres, abertos, verdes. [...] O exercício criador dessas
horas de lazer é um dos problemas fundamentais da nossa cidade. É
preciso, pois, organizar o espaço social para atender a essa demanda,
planejando um sistema completo de recreio... (BIRKHOLZ, 1964,
p.44).

O Plano Diretor de Presidente Prudente encontra-se disponível nas bibliotecas da FAU-USP (São Paulo) e da Faculdade de Ciências e Tecnologia FCTUNESP (Presidente Prudente) e apresenta-se em cinco volumes, sendo os três primeiros de análise, síntese e proposições e os dois últimos contendo as peças gráficas - pranchas de representação.

Foi elaborado através de um convênio entre a Prefeitura Municipal, o CPEU e a Associação dos Engenheiros e Arquitetos da Alta Sorocabana, para atender, segundo Marisco (1997) e dois objetivos: a implantação do Distrito Industrial e a promulgação da nova Lei Orgânica dos Municípios, em 1967. Anterior a este, os únicos planos elaborados como embasamento para políticas públicas foram o Plano 
Mínimo de Educação - PLAME, aprovado em 1966 e o Plano Sanitário e de Promoção Social, aprovado em 1968, portanto, contemporâneos à época de elaboração do Plano Diretor e que foram implementados parcialmente (MARISCO, 1997, p.71).

O esquema operacional adotado pelo CPEU, para os estudos do PDDI de Presidente Prudente, ou seja, as etapas dos trabalhos que seriam adotadas para a elaboração deste documento, conhecido como "Roteiro Básico" seguiram a sistemática definida pelo Centro de Estudos e Pesquisas da Administração Municipal - CEPAM, que lançou um Roteiro Básico para elaboração de Planos Diretores Municipais, e que de modo geral seguiu o recomendado pelo SERFHAU. (MARISCO, 1997, p.128).

As principais diretrizes definidas pelo Plano Diretor de Presidente Prudente e que cabem análise aqui são referentes à Hipótese de Expansão Urbana (figura 27), estabelecendo prioridades de ocupação, o Plano de Massas (figuras 29 e 30), que orienta o crescimento da mancha urbana e o zoneamento (figura 31), definindo o uso e ocupação do solo urbano.

Em relação às hipóteses de expansão urbana, o Plano Diretor estabelece diretrizes baseadas também no projeto para os distritos industriais; considera, assim, quatro áreas principais de possível expansão (figura 27):

1- Área localizada entre a rodovia Raposo Tavares e o Córrego do Veado;

2- Área delimitada ao norte pela linha férrea e a oeste pelo fundo de vale do córrego Ferreirinha;

3- Área compreendida entre a rodovia Raposo Tavares e os fundos de vale do córrego do Cedro e seus tributários;

4- Área urbana da zona Leste, compreendida entre a linha férrea e os fundos de vale dos córregos do Cachoeira Grande e Água Espraiada. 
Figura 27 - Hipótese de expansão urbana; os números representam as áreas que foram definidas como prioritárias.

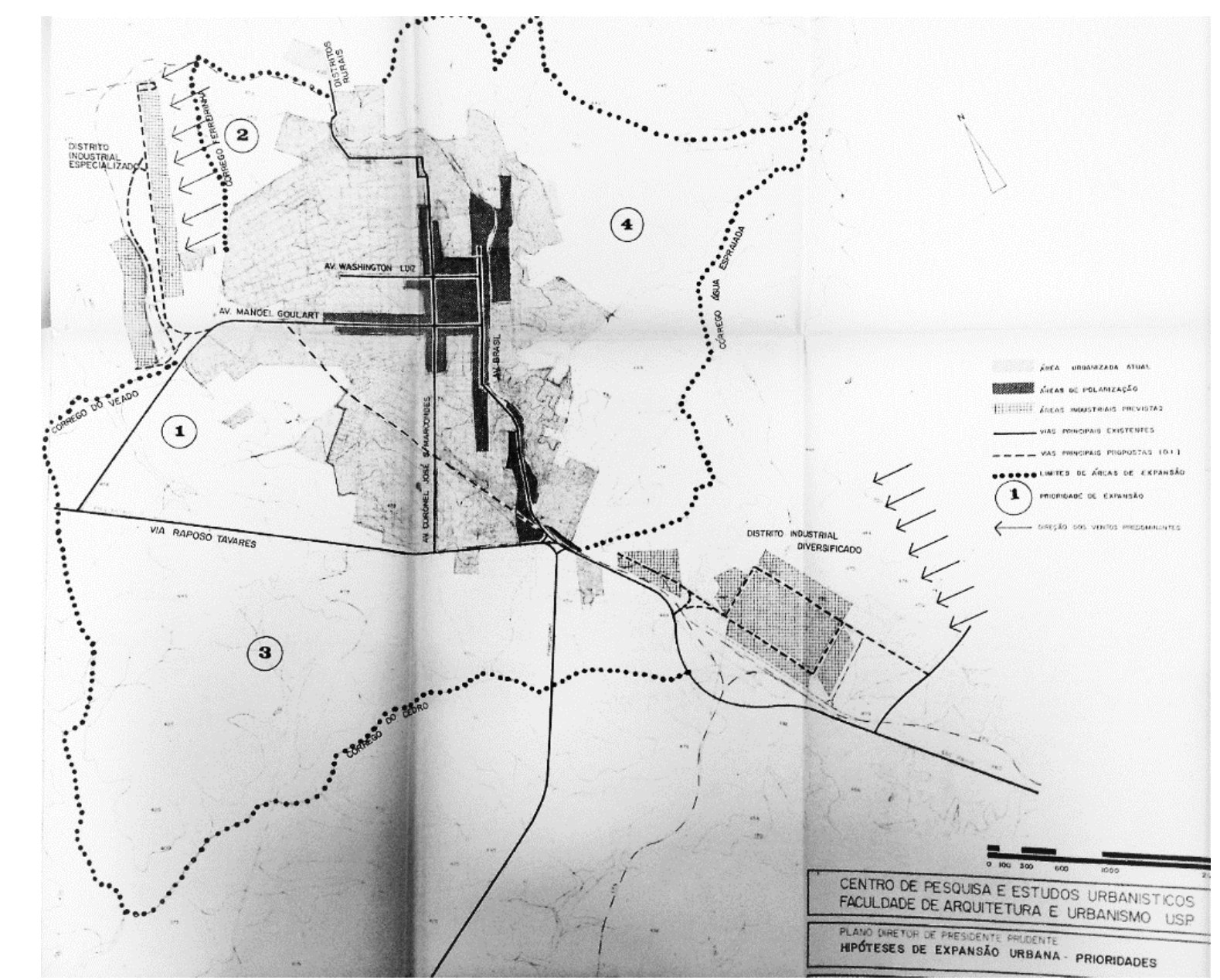

Fonte: Plano Diretor de Presidente Prudente (1969).

Nota-se, em comparação com a imagem de satélite atualizada (figura 28), que as áreas 1 e 2 das hipóteses de expansão urbana foram realmente ocupadas, bem como seus fundos de vale. A área 3 foi menos urbanizada, sendo ocupada atualmente em grande parte por condomínios fechados. A área 4, permanece como a área menos ocupada, na qual a problemática linha férrea, relevo e talvegues dos fundos de vale permanece até hoje como certo entrave a seu crescimento. 
Figura 28 - Malha urbana atual de Presidente Prudente, com demarcação da ferrovia (em vermelho) e do quadrilátero central, evidenciando o vetor de expansão a oeste da linha férrea.

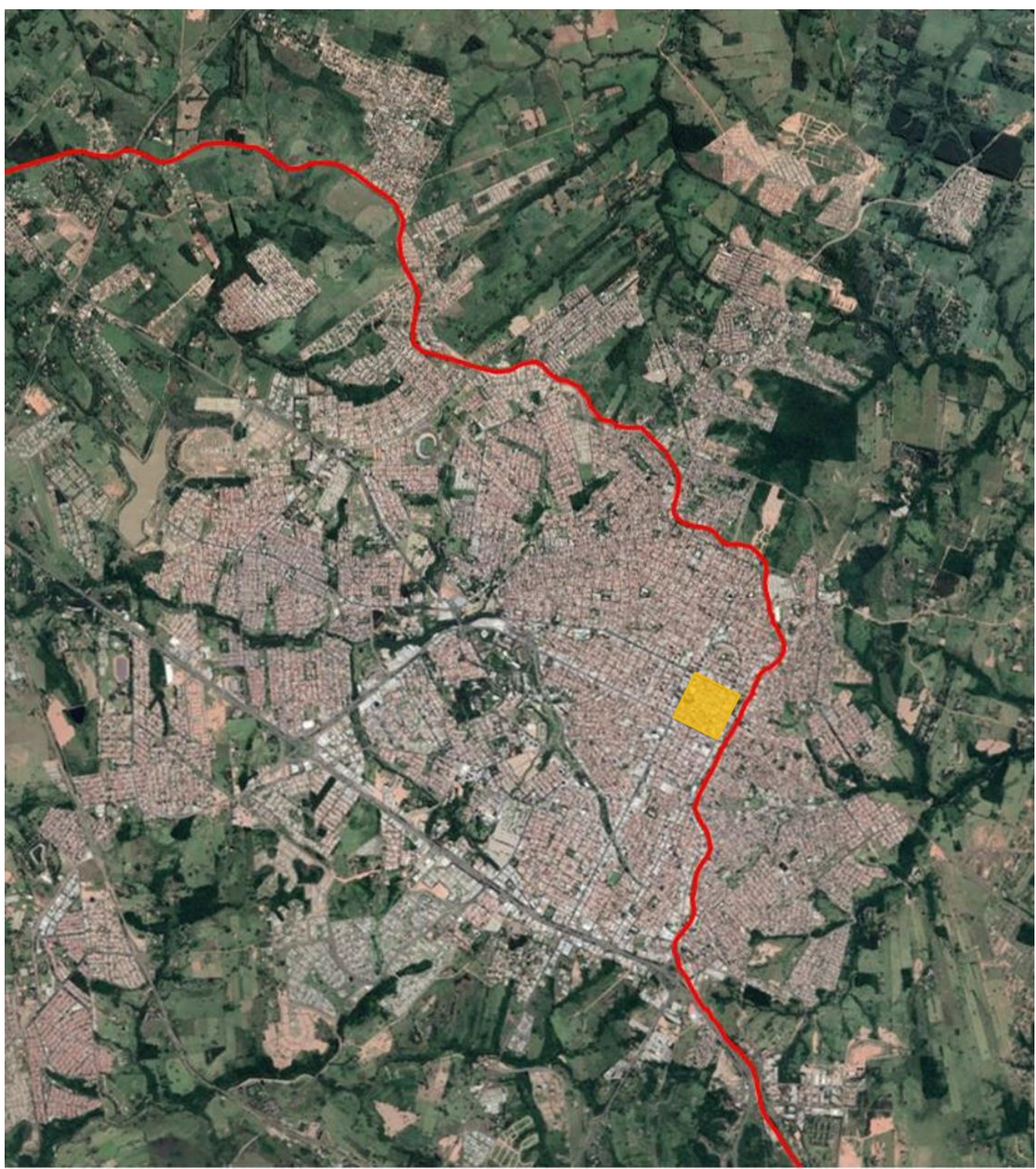

Fonte: Google Earth (2019), modificado pelo autor.

Enquanto isso, a região norte, depois de transposta a linha férrea, bem como a região oeste, depois de transposto os córregos Ferreirinha/Maracanã, Colônia Mineira e Veado, apresentaram desenvolvimento já no final da década de 1960, e que passou a ser ainda mais expressivo nas décadas de 1980 e 1990. Seja pela introdução do Código Florestal, em 1965, ou a aprovação da Lei n 6766, em 1979, observa-se que os fundos de vale não foram ocupados nessas regiões, gerando espaços livres ociosos, em sua maior parte desqualificados, e que muitas vezes não cumprem sua função social e ambiental, tornando-se barreiras na malha urbana.

Já o Plano de Massas (figuras 29 e 30) apresenta uma proposta de sistema viário através de uma malha direcional de vias expressas, muito semelhante ao que 
foi idealizado no Plano Urbanístico Básico (PUB) para São Paulo, também na década de 1960 - mais especificamente 1968, concomitante ao Plano Diretor de Presidente Prudente. Esse sistema de vias se conectaria às existentes e as zonas de polarização comercial se encontrariam ao longo desses corredores viários. O principal eixo de polarização complexa seria a avenida central Manoel Goulart e as ruas e avenidas pertencentes ao quadrilátero central inicial; em proximidade a estas, estariam concentradas as zonas de alta densidade.

O sistema viário do plano, porém, não veio a ser executado completamente, exceto por algumas avenidas transversais à Rodovia Raposo Tavares (Avenida Manoel Goulart, Avenida da Saudade, Avenida Cel. José Soares Marcondes, Avenida Brasil), bem como o eixo viário que conecta a zona leste à zona norte, acompanhando o espigão e a linha férrea (atual Avenida Presidente Juscelino Kubistchek); porém, não seguem fielmente aos planos.

Figura 29 - Plano de Massas e Sistema Viário existente e proposto.

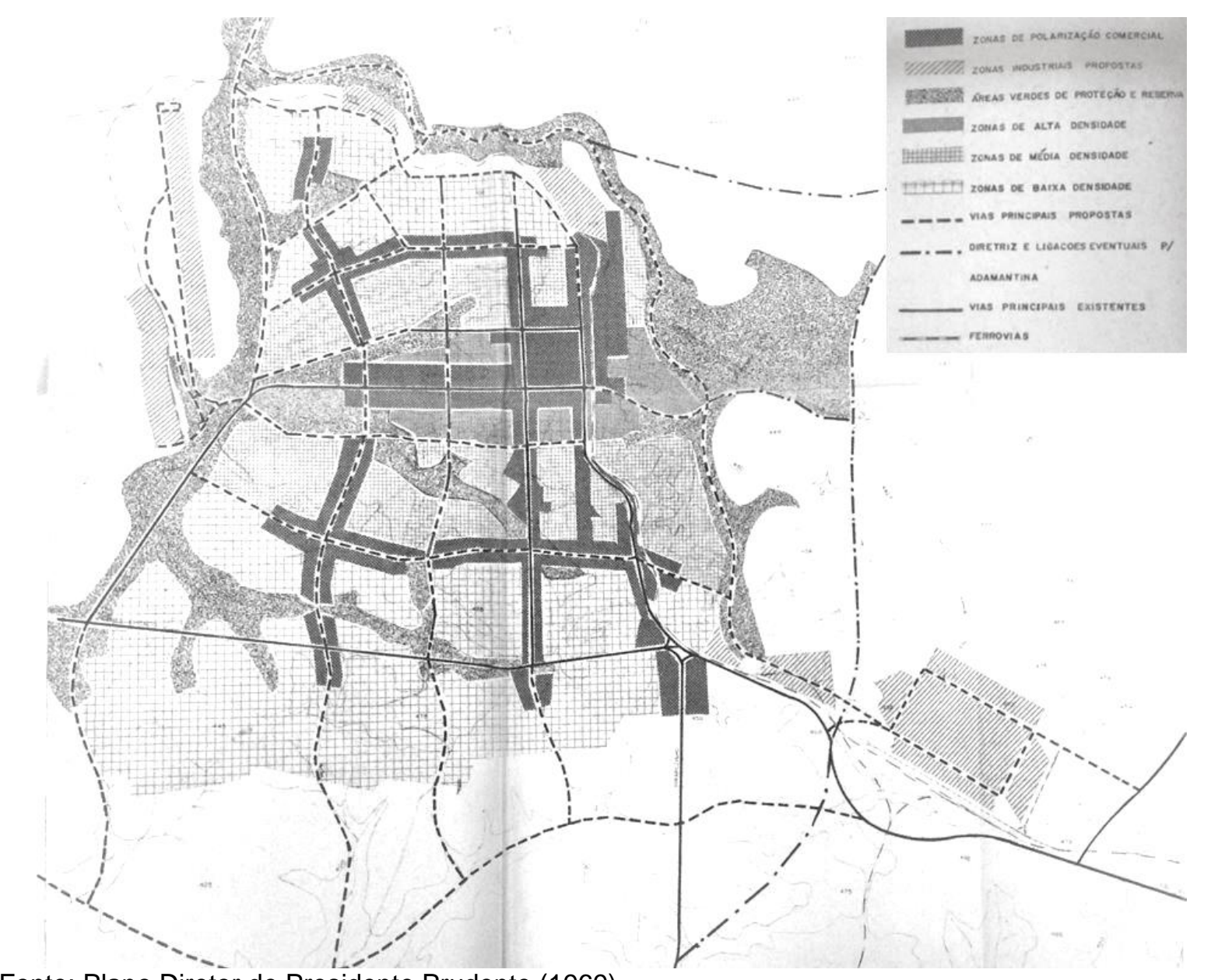

Fonte: Plano Diretor de Presidente Prudente (1969). 
As áreas verdes e de proteção e reserva propostas fariam parte de um projeto para aumentar significativamente a taxa de área verde por habitante, que era de $3,74 \mathrm{~m}^{2} /$ hab à época - o CPEU considerava aceitável um índice mínimo de 6,0 m²/hab (PLANO DIRETOR DE PRESIDENTE PRUDENTE, 1969).

Assim, seriam implantados um Parque Municipal na zona Leste - não construído - e seria aproveitada uma área de fundo de vale do Centro Educacional onde atualmente encontra-se o campus da UNESP - para constituir outra área de proteção e reserva - e que, neste caso, se efetivou. Outras áreas verdes e de proteção seriam constituídos pela preservação e qualificação dos fundos de vale (figura 30); na figura, pode-se observar a proposta de atrelar escolas e outras unidades de ensino aos fundos de vale e eixos viários principais, existentes e propostos.

\begin{abstract}
Através do aproveitamento paisagístico dos espaços vazios dos fundos de vale que cortam o tecido urbano deverá ser minimizada a ação erosiva e estendido às áreas residenciais, homogeneamente, o benefício da arborização. Estas providências deverão resultar, por fim, no aprimoramento urbanístico e paisagístico da cidade. (Plano Diretor de Presidente Prudente, 1969, p. 392, grifo nosso).
\end{abstract}

Figura 30 - Plano de Massas: proteção dos fundos de vale e apontamento das unidades de ensino, existentes e propostas.

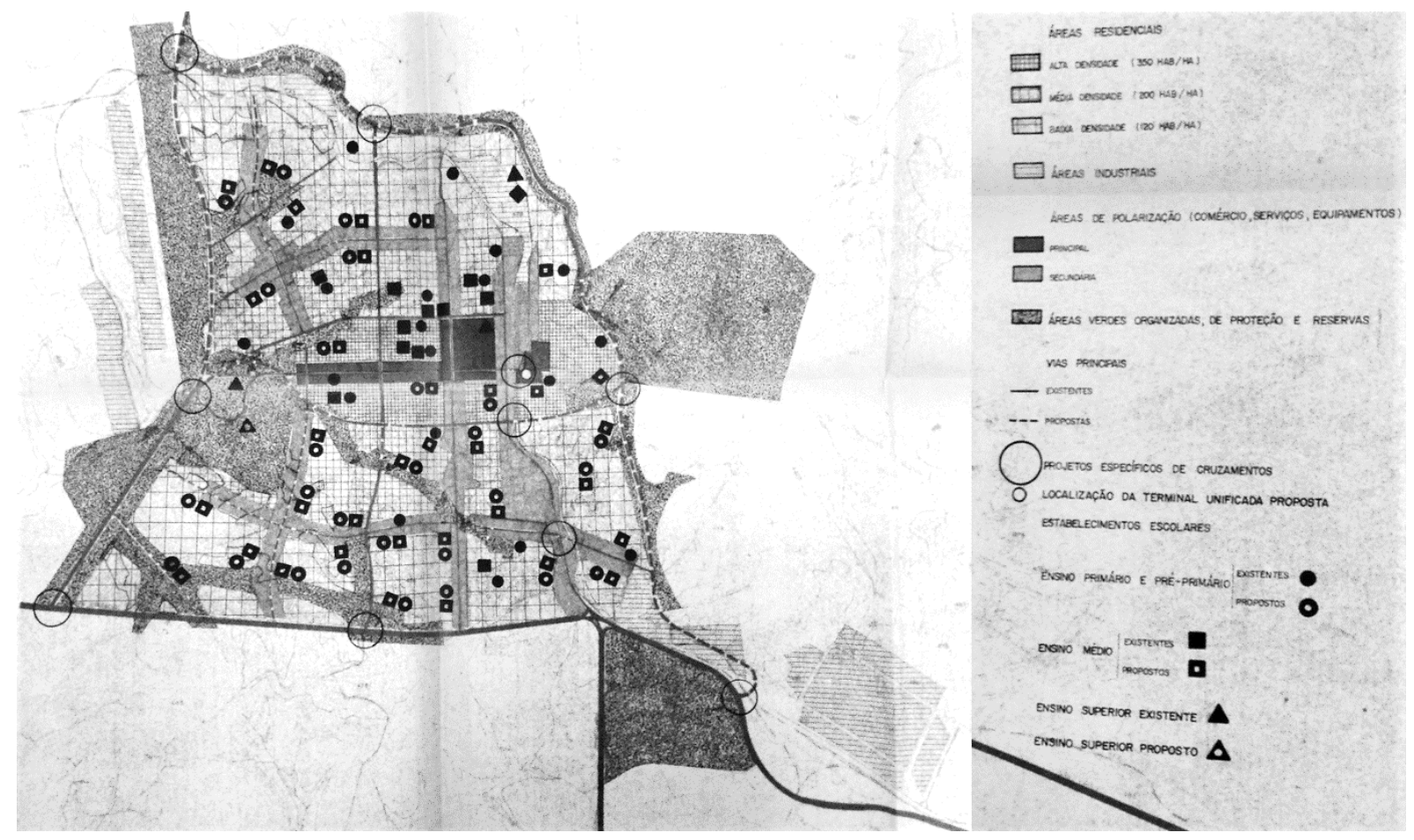

Fonte: Plano Diretor de Presidente Prudente (1969), prancha ํㅜㄱ- "Plano de massas 1968-1980".

Assim, a proposta final de zoneamento (figura 31) foi embasada pelo plano de massas e pelas hipóteses de expansão urbana para um período de quinze anos, 
aproximando-se da década de 1980. O parque municipal na zona leste não foi implantado - mas outros parques foram criados nesta zona nos últimos anos -, porém o Parque do Povo foi implantando em uma das zonas especiais de interesse paisagístico (córrego do Veado); o Centro Educacional e a zona de uso especial para exposição agropecuária são elementos presentes na mancha urbana bem como no zoneamento atual. Outras zonas industriais se desenvolveram, porém aquelas presentes no zoneamento proposto ainda apresentam certa quantidade de indústrias (o distrito industrial especializado não chegou a ser implementado de fato, mas o local concentra até os dias atuais algumas indústrias ligadas à carne). Quanto às zonas de comércio e residenciais, estas se alteraram pelo crescimento da população, em especial para sul e oeste da malha urbana, relacionado ao desenvolvimento do eixo do Parque do Povo, da Raposo Tavares e das rodovias de acesso aos municípios vizinhos, que criaram outros corredores de comércio e serviços e permitiram acesso a novas regiões, com formação de novos loteamentos.

Figura 31 - Zoneamento proposto.

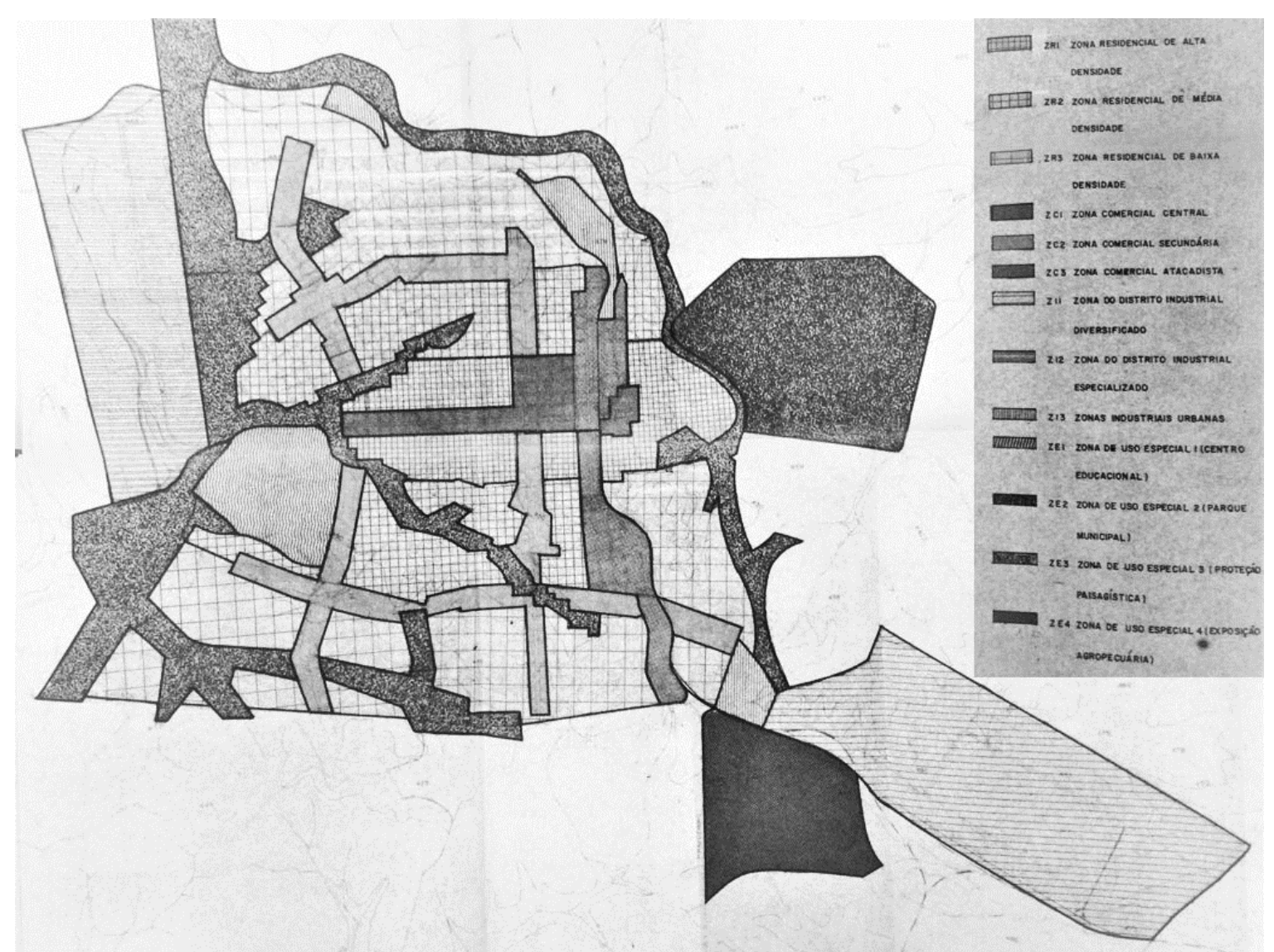

Fonte: Plano Diretor de Presidente Prudente (1969). 
O Plano Diretor de Desenvolvimento Integrado de Presidente Prudente, que passou pelas primeiras discussões e aprovações na Câmara Municipal ainda em 1960 e teve seus estudos e análises entregues pelo CPEU em 1968/1969, só viria a ser aprovado em 1973, passando por três gestões municipais; ainda segundo Marisco (1997), o principal fator na interrupção do processo foram as mudanças políticas ocorridas.

A aprovação do Plano viria a ocorrer através da Lei n 1582, de 05 de dezembro de 1973, na gestão de Walter Lemes Soares, que se referia ao Plano como instrumento fundamental para ordenação do processo de crescimento do município. Concomitante à aprovação deste, a Lei oํ 1583/1973 aprovaria também os princípios de zoneamento e uso e ocupação do solo no município.

A principal crítica que se faz ao Plano Diretor de 1968/1969 é que o atraso na aprovação deste, que levou sete anos desde a assinatura dos convênios até sua efetiva aprovação, provocando a inexequibilidade de alguns projetos, que não mais eram fundamentais ou já haviam sido definidos de maneira diferente. Neste sentido, o Plano Diretor, como em muitas das cidades brasileiras, fez-se realidade apenas como instrumento regulador do espaço urbano, visto que a cidade de Presidente Prudente também não possuía zoneamento e lei de uso e ocupação. No mais, o Plano Diretor foi importante para pedidos de financiamento, perante o governo federal, para obras de infraestrutura e recuperação de fundos de vale.

O que cabe ressaltar é que, ao mesmo tempo em que houve a proposta de canalização de córregos e seu tamponamento - como os casos dos córregos Água Bôscoli e Bacarin - houve também a proposta de construção de um parque linear em um dos fundos de vale - o do Córrego do Veado. Como mostrado, o plano diretor elaborado pelo CPEU delineava uma nova centralidade neste fundo de vale, como um novo eixo estruturante para a cidade, que até então entendia o córrego como uma barreira ao desenvolvimento urbano.

\subsubsection{Parque do Povo}

O Parque do Povo foi construído no trecho inicial do Córrego do Veado, entre as Avenidas Brasil e Manoel Goulart, estendendo-se por aproximadamente três quilômetros no sentido NW-SE. As obras iniciaram-se em 31 de outubro de 1976 e o projeto, desenvolvido pelo escritório dos arquitetos Vera Catunda Serra e Geraldo 
Serra, estendia-se por uma área de 460 mil m², contemplando a canalização fechada nos trechos iniciais e canalização aberta nos trechos seguintes ${ }^{42}$.

O projeto, apresentado à população pela Prefeitura Municipal com o nome Fundo de Vale foi justificado ${ }^{43}$ como necessário a expansão territorial da cidade, corroborado pelas análises realizadas pelo CPEU para o Plano Diretor, e os recursos para seu desenvolvimento vieram através do Fundo de Desenvolvimento Urbano (FDU) e do Departamento Nacional de Obras e Saneamento (DNOS), conforme relata Silva (1994). Em 1977, o financiador de recursos passou a ser o Programa CURA (Comunidade Urbana para Recuperação Acelerada), que iria destinar também recursos para a canalização e melhorias nos fundos de vale de outros dois córregos afluentes do Córrego do Veado.

O projeto (figura 32) era composto, segundo Silva (1994), por melhorias no sistema viário, com a pavimentação de 52 mil m²; saneamento, com a retificação do córrego do Veado (figura 33); a delimitação de áreas de recreação e lazer, que seriam compostas pelos seguintes equipamentos: 06 parques infantis, 05 lanchonetes e sanitários, 04 quadras de voleibol, um conjunto de piscinas, uma pista de atletismo, 13 quadras de futebol de salão, 04 canchas de bocha, 09 quadras de basquetebol, kartódromo, bosques e jardins, estacionamentos e a reforma do Estádio Municipal.

Figura 32 - Anteprojeto de Urbanização do Fundo de Vale do Córrego do Veado

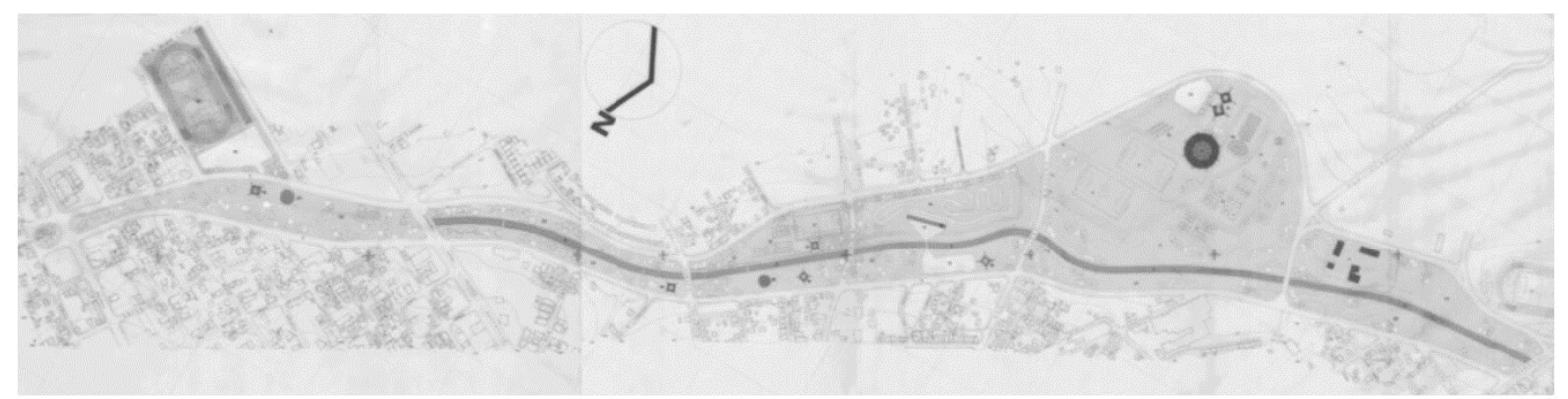

Fonte: Museu e Arquivo Histórico Antônio Sandoval Netto.

42 A canalização do córrego, realizada através de um convênio com o Departamento Nacional de Obras e Saneamento Básico - DNOS, foi autorizada pela Lei oㅡ 2008 de 1978.

${ }^{43}$ Decreto Municipal no 2568 de 1976, que apresenta as diversas justificativas consideradas pelo poder público municipal para a desapropriação dos terrenos e lotes que dariam origem à "implantação de planos de urbanização", que na prática correspondem à "implantação de rede viária margeando o fundo de vale e de áreas de preservação paisagística", conforme é descrito no próprio texto do decreto. Em resumo: canalização do Córrego do Veado, construção de vias marginais e implementação do que viria a ser o Parque do Povo. 
Figura 33 - Córrego do Veado retificado e canalizado em trecho do Parque do Povo.

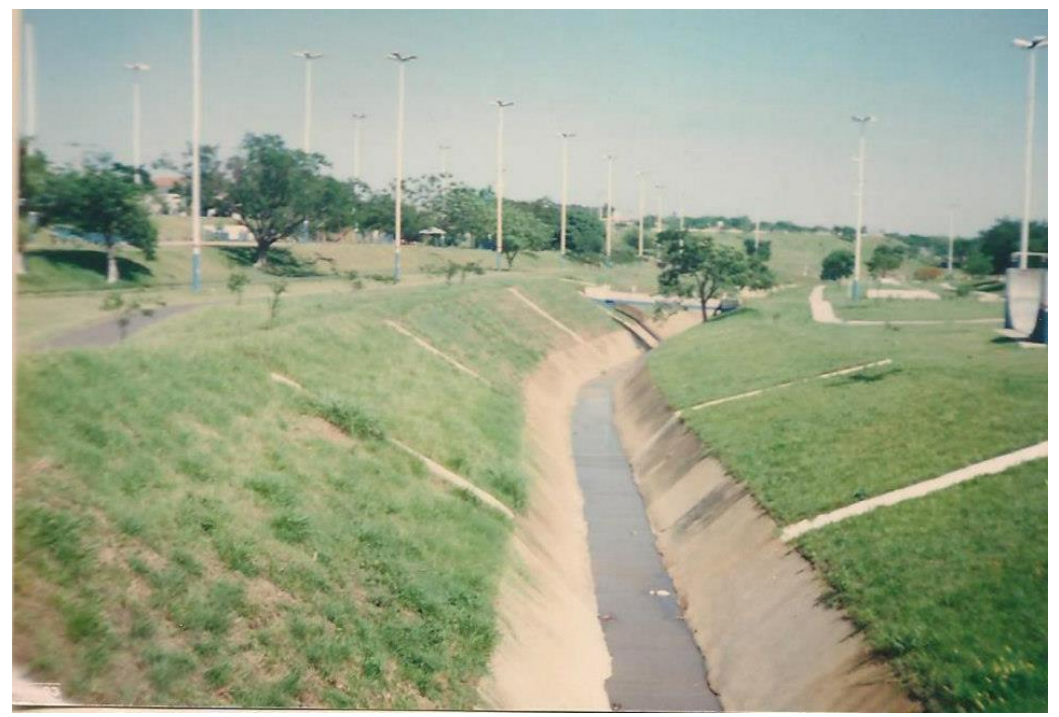

Fonte: Amorim (1993)

Ao todo, 330 lotes foram desapropriados e muitas famílias receberam valores de indenização muito baixos e/ou foram realocadas em bairros muito distantes; além disso, algumas escolhas pautadas por análises pouco aprofundadas em relação à natureza dos solos levariam a gastos não programados, como a substituição das canalizações após desmoronamentos das placas de arrimo da canalização aberta (figura 34).

Silva (1994) e Bortolo (2012) mostram que nem todos os equipamentos propostos foram implantados e reformas posteriores levaram também à substituição - no decorrer da década de 1990 - da canalização aberta trapezoidal pela canalização fechada ao longo de todo o Parque do Povo, compreendido entre a Avenida Brasil e a Avenida Manoel Goulart. No início da década de 1990, seria inaugurado também o Prudenshopping, centro de compras instalado em área localizada ao final do Parque do Povo, e cujo parte do estacionamento foi também instalado sobre o Córrego do Veado, em mais um trecho que foi canalizado e tamponado. 
Figura 34 - Desmoronamento das placas da canalização do Córrego do Veado, no Parque do Povo.

Fonte: Amorim (1993).

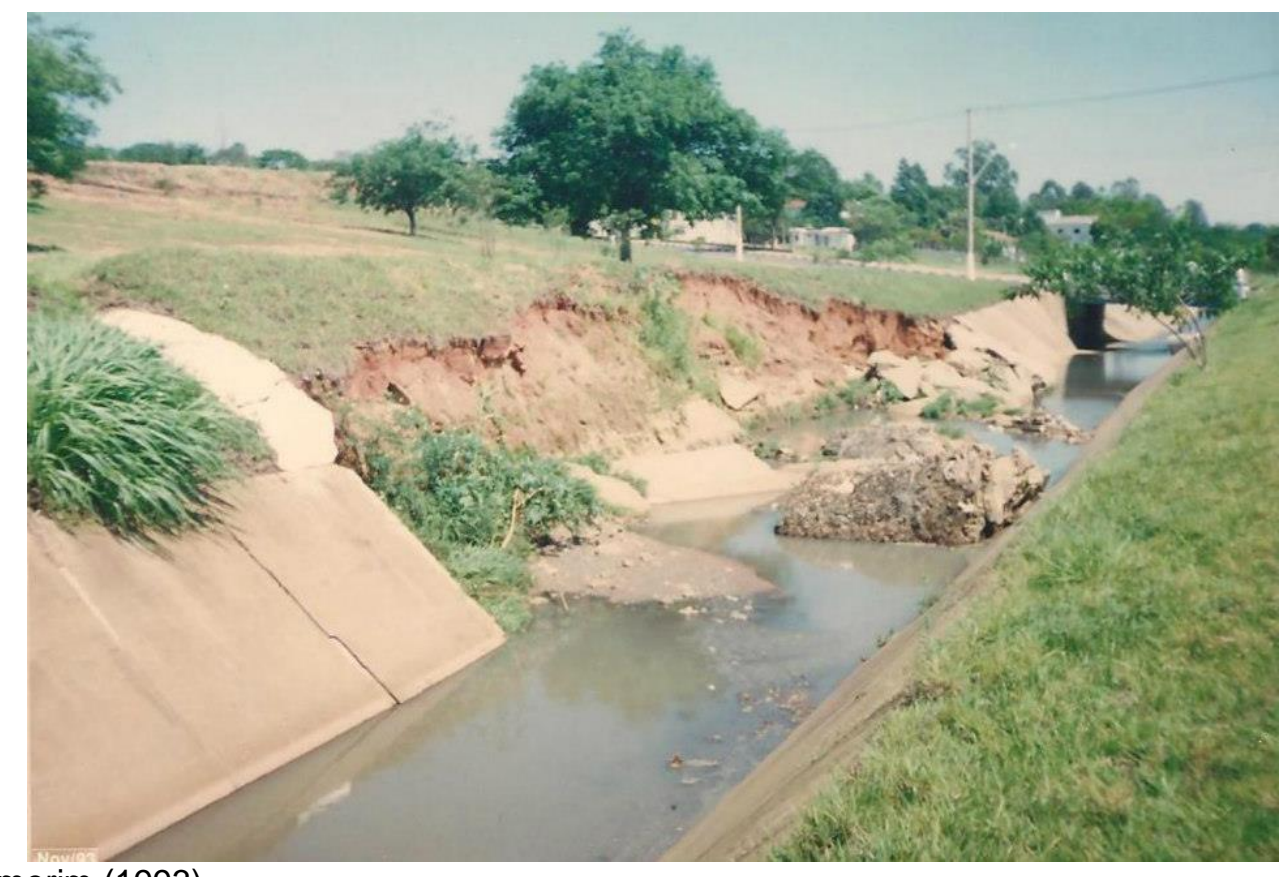

Como relatam Hora e Silva (1991, p. 86), "ao investir maciçamente no projeto, o poder público local provocou uma transformação expressiva na porção sudoeste da cidade", que passou a receber imóveis residenciais de alto padrão, "mudando o eixo de maior demanda de lotes e de maior status social, dos loteamentos localizados grosso modo ao norte da avenida Washington Luiz, para aqueles localizados ao longo do Parque do Povo" (SPOSITO, 1983, p. 216).

Pouco tempo depois de sua inauguração e até os dias atuais, a região sofre com inundações e enchentes periódicas, de grandes proporções, por ser a principal vertente para as águas pluviais da região central fortemente impermeabilizada de Presidente Prudente.

Ainda assim, o Parque do Povo se apresenta atualmente (figura 35) como principal espaço público de lazer e cultura da cidade, se apresentando como um parque linear que deu identidade à cidade e faz parte do imaginário da população. As questões atuais relacionadas ao parque e a ocupação e transformação do fundo de vale e do Córrego do Veado serão abordadas no capítulo posterior. 
Figura 35 - Área do Parque do Povo em Presidente Prudente.

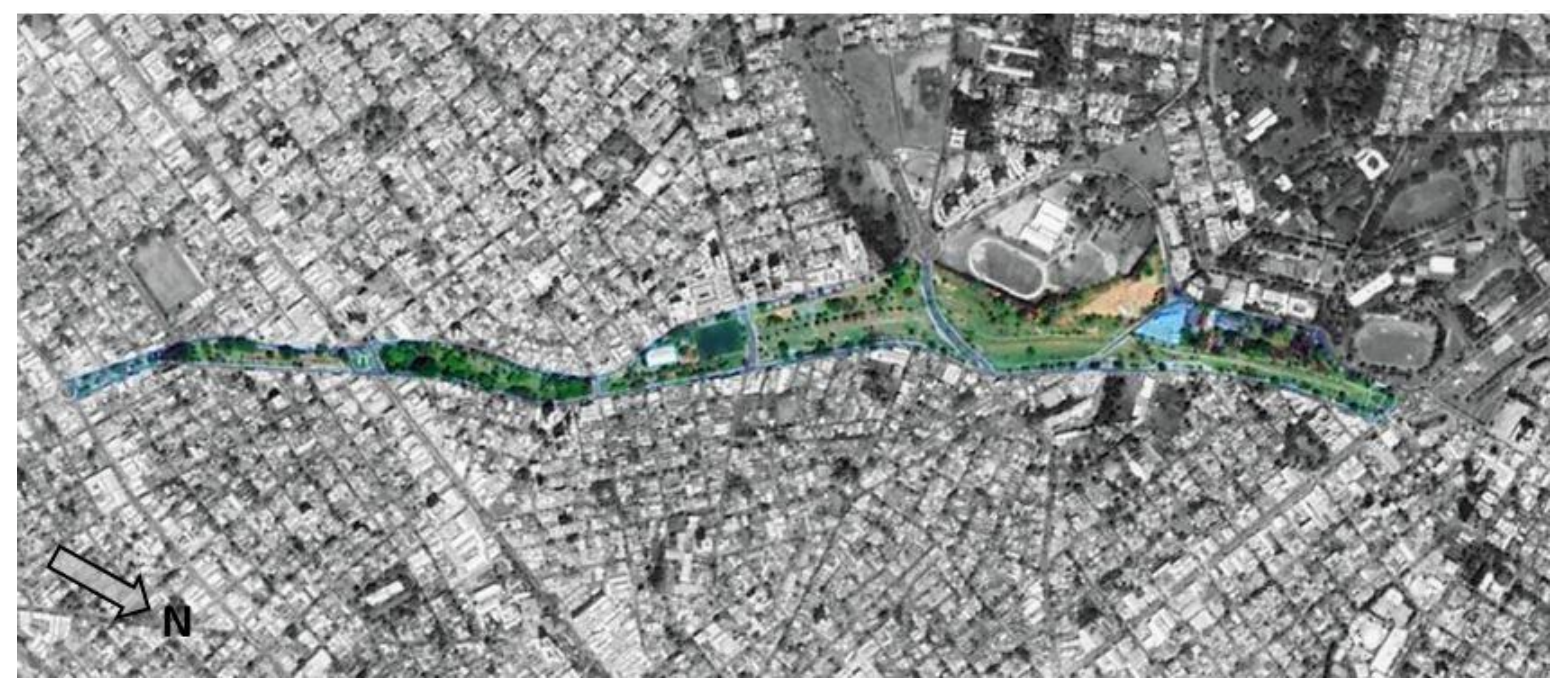

Fonte: Google Earth (2018), modificado pelo autor.

\subsubsection{Programa CURA em Presidente Prudente}

O Programa CURA (Comunidade Urbana para Recuperação Acelerada) foi uma política urbana desenvolvida com o intuito de promover o progresso nas cidades a partir de obras que articulassem sistemas viários, transportes, saneamento básico, iluminação, investimento em áreas de recreação, lazer, educação e cultura.

Segundo Lucchese (2004), nasceu a partir de uma proposta do arquiteto Harry James Cole em 1972, passando a ser operado nacionalmente a partir de 1973 pelo BNH (Banco Nacional da Habitação) e atuando até 1986, quando o BNH foi extinto.

Em Presidente Prudente, os recursos para os Projetos CURA foram obtidos entre 1977 e 1982, na administração de Paulo Constantino e três fases do programa foram implementadas, sendo responsáveis, segundo Lucchese (2004, p. 239), respectivamente, por:

a) CURA I e II: obras de drenagem (canalização dos córregos citados anteriormente e construção de galerias pluviais em vários bairros); implantação de equipamentos públicos (creches da Vila Formosa e do Jardim Monte Alto); implantação de um equipamento de lazer (Parque do Povo); construção do calçadão (rua de pedestres) na região central; e implantação do Balneário Público, atualmente Sesc Thermas de Presidente Prudente. 
b) CURA III: realizado na zona leste, promoveu a construção de acessos à região, canalização do córrego do Salto e construção sobre ele da Avenida Tancredo Neves, além da construção de creches e postos de saúde e implantação de três novas praças.

Como dito, além da construção do Parque do Povo, o Programa CURA foi responsável pelas obras de saneamento e canalização de outros dois córregos afluentes do Córrego do Veado: o Córrego Bacarin e o Córrego Água Bôscoli; além do córrego do Salto, na zona leste. A figura 36 apresenta a localização dos mesmos.

Porém, diferentemente daquele, que mesmo canalizado teria suas áreas contíguas transformadas em um parque linear, com projeto urbano e de paisagismo, os Córregos do Bacarin e Água Bôscoli, seriam totalmente canalizados e tamponados, a partir das verbas do Programa CURA, passando a ser suprimidos da paisagem urbana e dos olhos da população. O Córrego do Salto, por sua vez, também seria canalizado e tamponado em seu trecho inicial.

Figura 36 - Á esquerda, geomorfologia de Presidente Prudente: as áreas escuras representam as áreas de espigão. Á direita, Córregos: do Veado (número 1), Água Bôscoli (2), Bacarin (3) e Salto (4,) sobre imagem atual.
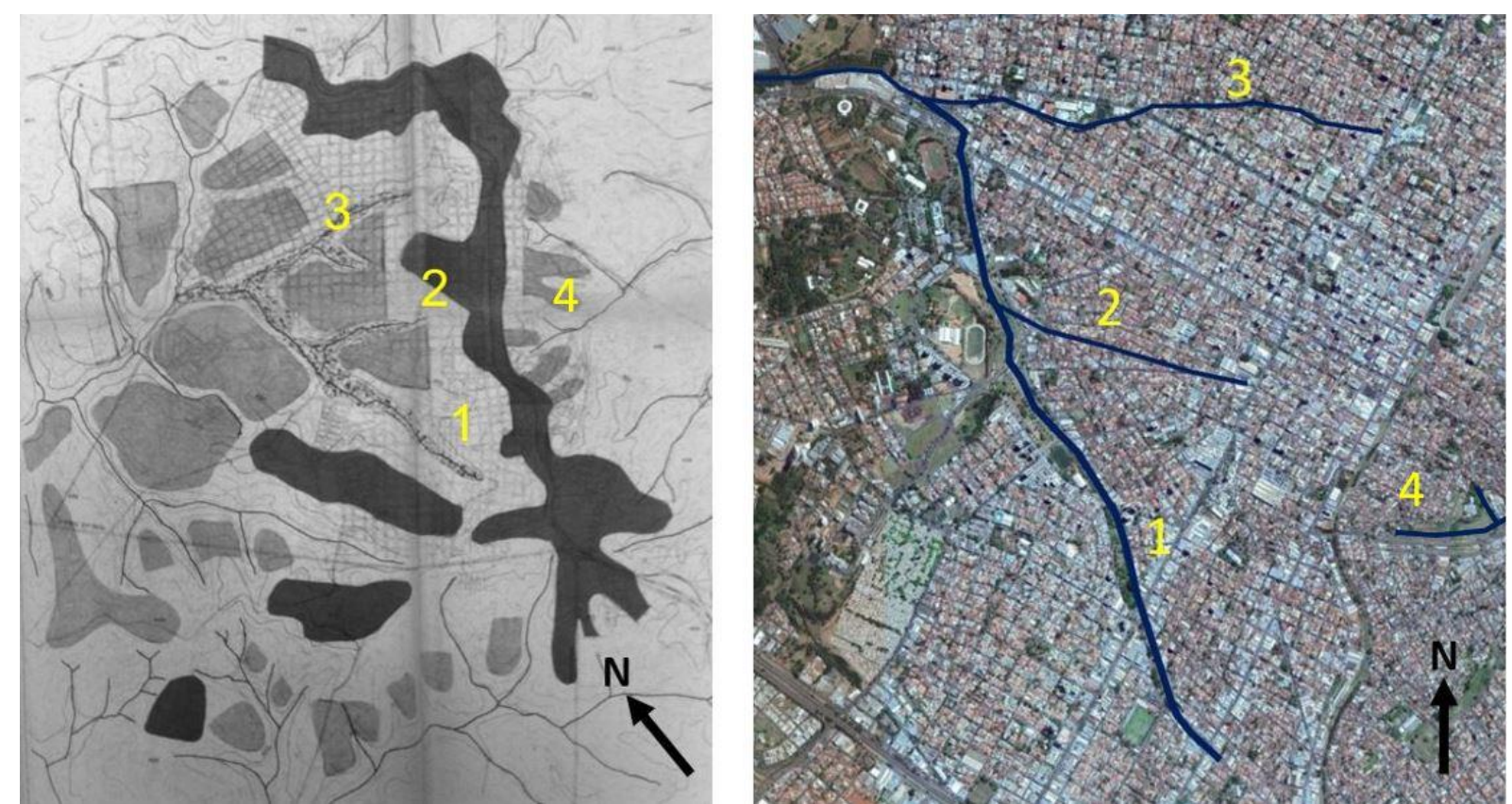

Fonte: respectivamente, Plano Diretor CPEU (1969) e Google Earth (2017), modificados pelo autor. 


\subsection{Histórico: a expansão urbana a partir da década de 1980}

Como visto, o Plano Diretor foi aprovado em 1973 tendo em vista a implantação do Distrito Industrial e a necessidade de recursos advindos do governo, que apenas liberava estes se houvesse um Plano Diretor Municipal; a malha urbana continuou a se desenvolver pela anexação de loteamentos e é durante a década de 1970 que novas dinâmicas de produção do espaço urbano influenciariam em alterações nesse processo.

Nos anos de 1950 e 1960, na lógica da descentralização industrial e do avanço do modelo rodoviarista interligando esses novos polos econômicos e produtivos pelo estado, Presidente Prudente recebeu especial atenção - com o projeto para um distrito industrial - e também com a abertura da rodovia Raposo Tavares, que conectava a cidade diretamente com a capital do estado. Nesta época, os processos de expansão e produção do espaço podem ser reconhecidos como de estruturação urbana. A partir de meados da década de 1970, como relatado anteriormente, as cidades médias, que já haviam passado por um processo de estruturação urbana, vivenciariam um processo de reestruturação (BELTRÃO SPOSITO, 2007).

Tenho chamado de estruturação ou reestruturação urbana as dinâmicas e processos atinentes aos espaços regionais e/ou ocorridos no âmbito das redes urbanas; como estruturação ou reestruturação da cidade, compreendo dinâmicas e processos que ocorrem na escala intra-urbana. (BELTRÃO SPOSITO, 2007, p. 2)

Com Presidente Prudente, não foi diferente. A capital da alta sorocabana, que mantém o título histórico até os dias atuais, veria sua ferrovia sucumbir ao modelo rodoviário e então as indústrias se alinhariam às avenidas principais, mesmo que na periferia - com fácil acesso ao centro e também às rodovias - e os novos distritos industriais (figura 37 , indicado pelo número 1) se localizariam próximos aos eixos rodoviários - com foco principal na rodovia Raposo Tavares, que conecta Presidente Prudente a São Paulo e também à fronteira com Mato Grosso do Sul e na rodovia Assis Chateaubriand, que conecta a cidade com o estado do Paraná e a outros polos regionais no norte do estado de São Paulo, como Araçatuba, São José do Rio Preto, Barretos e Franca.

A região do Parque do Povo se (figura 37 , indicado pelo número 2) constituiria em uma nova centralidade para a cidade, tendo como ápice a instalação de um 
shopping center, o segundo da cidade - no início dos anos 1990 - (figura 37, indicado pelo número 3) ao final do parque e às margens da avenida Manoel Goulart - um nó urbano que conecta centro, Parque do Povo e uma rede de avenidas para outros bairros periféricos. Como será mostrado em capítulo posterior, a construção do shopping não apenas ocupou o fundo de vale como também canalizou e tamponou o Córrego do Veado para a construção do estacionamento do centro de compras.

É também durante a década de 1970 e inícios dos anos 1980 que ocorre a instalação dos primeiros loteamentos fechados em Presidente Prudente (SOBARZO, 1999) ${ }^{44}$ - o primeiro deles, Jardim Morumbi, aprovado em 1975 (figura 37, indicado pelo número 4), distante da malha urbana consolidada e o segundo, João Paulo II, aprovado em 1980 (figura 37, indicado pelo número 5), localizado em uma das avenidas criadas pela diretriz estabelecida pelo Projeto de um Distrito Industrial, próximo ao recém-inaugurado Parque do Povo.

O aparecimento desses novos empreendimentos residenciais vem alterando as relações entre o centro e a periferia nas cidades de porte médio e esta constatação é um dos fundamentos da ideia de que passamos por uma reestruturação da cidade. [...]

Até os anos de 1970 e 1980, a circulação intra-urbana nessas cidades articulava-se em torno de um centro principal, compondo estruturas monocêntricas fortemente integradas a uma única área importante de concentração de estabelecimentos comerciais e de serviços. Nos últimos vinte anos, observou-se multiplicação de áreas de concentração dessas atividades (eixos comerciais, centros comerciais em bairros de bom poder aquisitivo e shopping centers), bem como verificou-se o fenômeno de diversificação delas, acompanhado de segmentação dos mercados consumidores, segundo diferentes padrões de consumo e maior ou menor facilidade para se locomover por automóvel. (BELTRÃO SPOSITO, 2007, p. 5-6)

Nos anos 1990, a dispersão urbana é representada pela instalação do conjunto habitacional Ana Jacinta - COHAB Ana Jacinta, em 1992, (figura 37, indicado pelo número 6) - em um loteamento distante dez quilômetros do quadrilátero central. Os condomínios fechados da elite teriam sua expansão pela região Sul, o primeiro deles, Parque Residencial Damha seria aprovado em 1996 (figura 37, indicado pelo número 7) e os mais recentes conjuntos habitacionais, para a região Norte da malha urbana, como o Conjunto Habitacional Jardim João Domingos Netto (figura 37, indicado pelo número 8 ), inaugurado ao final de 2015 , fruto das políticas habitacionais

44 SOBARZO, Oscar. A segregação socioespacial em Presidente Prudente: análise dos condomínios horizontais. Presidente Prudente, 1999. 213f. Dissertação (Mestrado em Geografia) - Faculdade de Ciências e Tecnologia, UNESP. 
do programa Minha Casa Minha Vida. Esta expansão horizontal da mancha urbana em Presidente Prudente é característica de um processo de reestruturação urbana verificado em muitas outras cidades médias (BELTRÃO SPOSITO, 2007) e abordado no capítulo inicial deste trabalho.

Figura 37 - Expansão da área urbana no período 1920 - 2015.

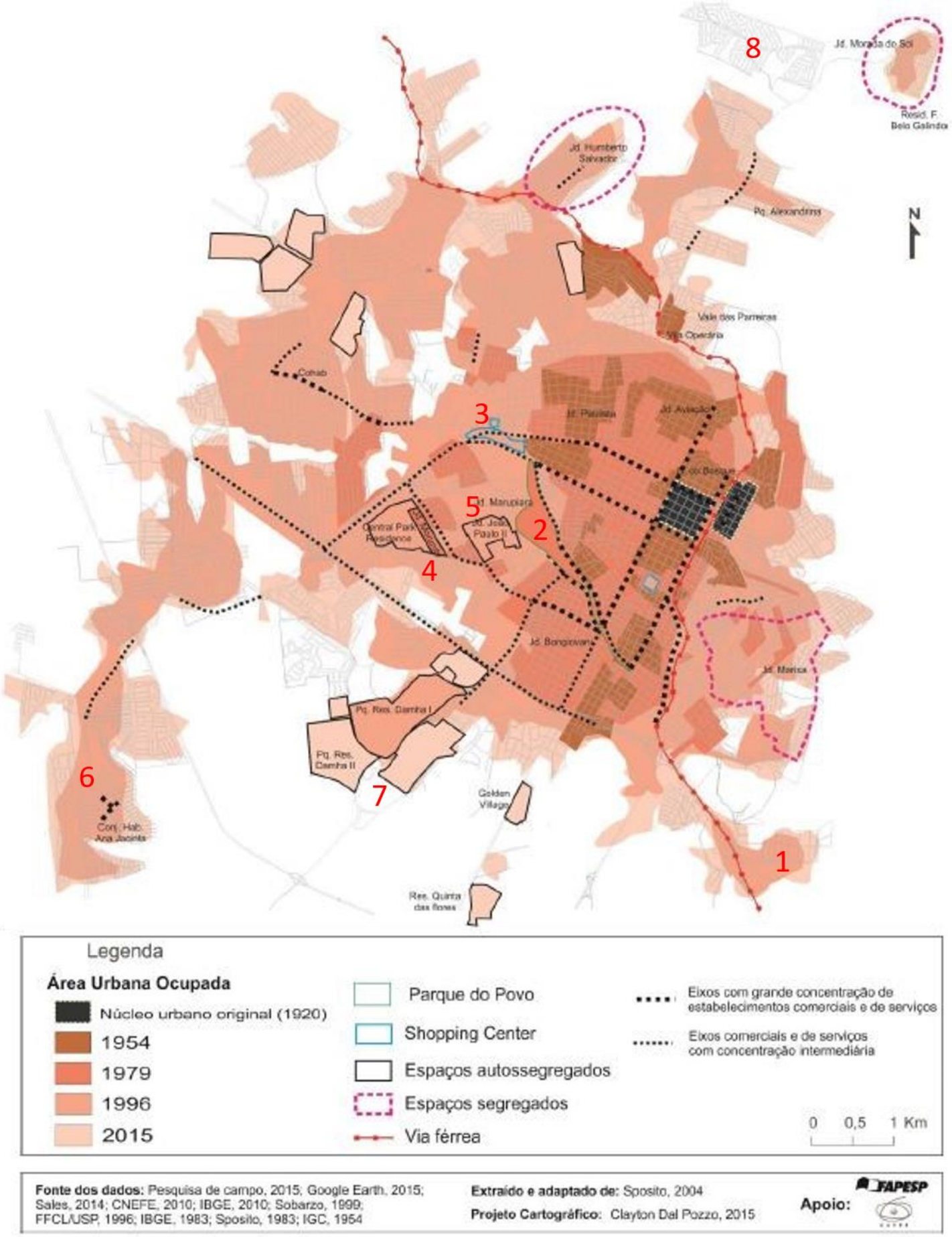

Fonte: Dal Pozzo (2015), modificado pelo autor. Os números representam, respectivamente: 1- Distrito Industrial proposto e realizado, em partes, 2-Parque do Povo, 3- Prudenshopping, 4-Jardim Moumbi, 5Jardim João Paulo II, 6- COHAB Ana Jacinta, 7- Condomínios fechados, 8- Programa MCMV, Conjunto Habitacional Jardim João Domingos Netto. 
Assim, em sua evolução, a mancha urbana da cidade deixou de ser "compacta" (Plano Diretor de Presidente Prudente, 1969, p.305), passando a ser espraiada, repleta de áreas de interesse especulativo, mas também de muitos espaços livres - passíveis de qualificação.

Os fatores responsáveis não se restringem apenas à ocasião do Plano, mas também a fatores como a aprovação do Código Florestal (Lei № 4771, de 15 de setembro de 1965), Lei de Parcelamento do Solo Urbano (Lei № 6766, de 19 de dezembro de 1979), que criam áreas de preservação dos cursos d'água, áreas verdes e de circulação mínimas nas novas glebas loteadas, e à criação de estoques de terras a fim de especulação imobiliária ${ }^{45}$.

A seguir (figuras 38 e 39), apresenta-se um comparativo com dois mapas: o primeiro, do IBGE (1974), e o segundo, do Google Earth (2019). Através deles, evidencia-se a expansão urbana de Presidente Prudente na direção oeste da linha férrea, como também o momento no qual a legislação passa a intervir e a preservar os fundos de vale e cursos d'água.

No primeiro mapa, observa-se como a cidade se desenvolveu tamponando córregos e ocupando os fundos de vale e como a chegada da malha urbana ao córrego do Veado ocorre em um momento de viragem nas questões legislativas - para constar e relembrar, é na década de 1970 que ocorre a canalização do Córrego do Veado, com a justificativa de que representava um entrave ao desenvolvimento da cidade, e é também a década em que se constrói o Parque do Povo.

No segundo mapa, é evidente a presença das áreas de preservação permanente em meio urbano e também como a malha urbana passou a ser dispersa. As áreas localizadas a norte da linha férrea representam um novo vetor de crescimento para as classes média e baixa, enquanto a área ao sul da rodovia Raposo Tavares, desocupada até os anos do mapa anterior, tornou-se um vetor de expansão de comércios e serviços, além de condomínios fechados.

\footnotetext{
45 Urbaniza-se uma área distante, desconexa da malha urbana por um grande vazio urbano, para que, ao qualificar-se aquele novo loteamento, o preço da terra vazia entre ele e a cidade aumente (Villaça, 1999).
} 
Figura 38 - Presidente Prudente em 1974, com demarcação do córrego do Veado (em azul).

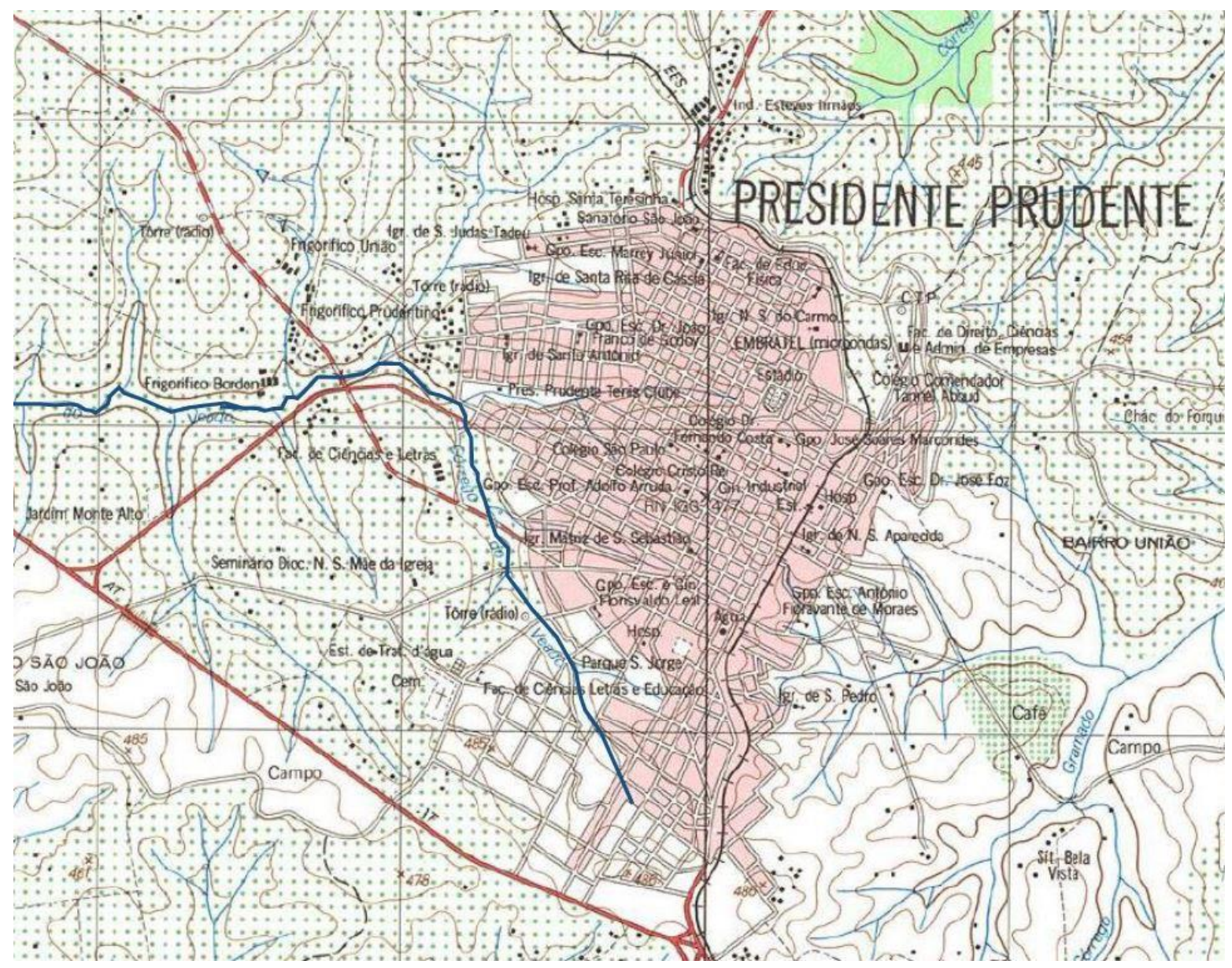

Fonte: IBGE, modificado pelo autor. Disponível em:

https://biblioteca.ibge.gov.br/visualizacao/mapas/GEBIS\%20-\%20RJ/SF-22-Y-B-III-1.jpg 
Figura 39 - Presidente Prudente, 2019, com demarcação do córrego do Veado (em azul), da linha férrea (em vermelho) e do quadrilátero central (em amarelo).

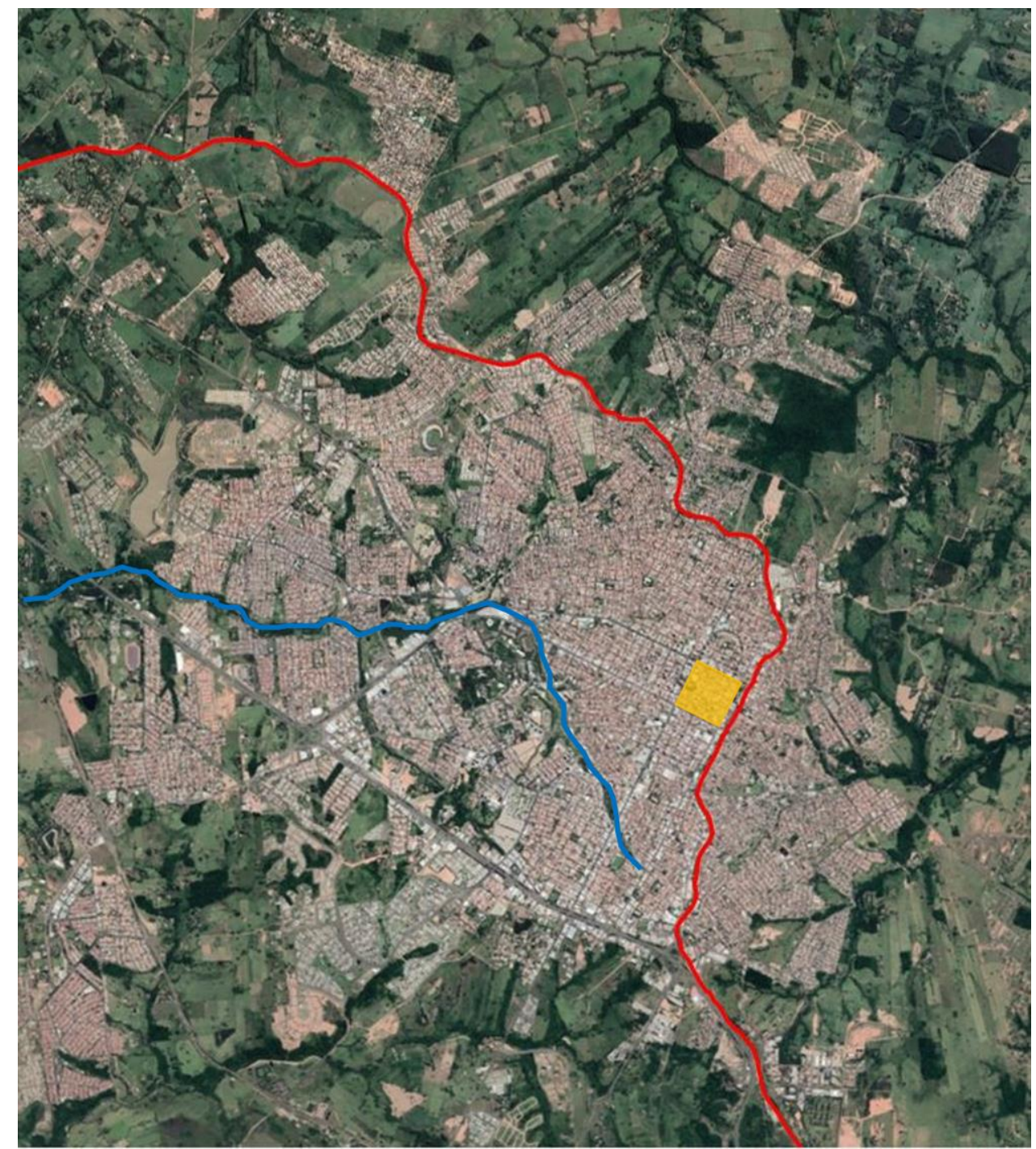

Fonte: Google Earth (2019), modificado pelo autor.

A figura 40 apresenta uma sequência de mapas da expansão urbana de Presidente Prudente sobre o relevo e hidrografia originais. Nele, observa-se, por períodos e décadas, a expansão urbana da cidade frente aos processos até aqui abordados. Entre 1960 e 1982 é que se percebe a ruptura no processo de crescimento compacto da malha urbana; a década de 1990 e os anos 2000 apenas ratificam esse modelo de desenvolvimento que é, na verdade, uma somatória de todos os processos de planejamento, planos, legislações e produção do espaço urbano até aqui apresentados. Na sequência de mapas é possível notar como a expansão urbana de Presidente Prudente, que se iniciou no espigão das terras, ocupou o território dos fundos de vale da bacia do Córrego do Veado e, principalmente a partir dos anos 1980, expandiu-se por outras bacias. 
Figura 40 - Expansão da malha urbana de Presidente Prudente-SP sobre o relevo (1917 - após 2000).
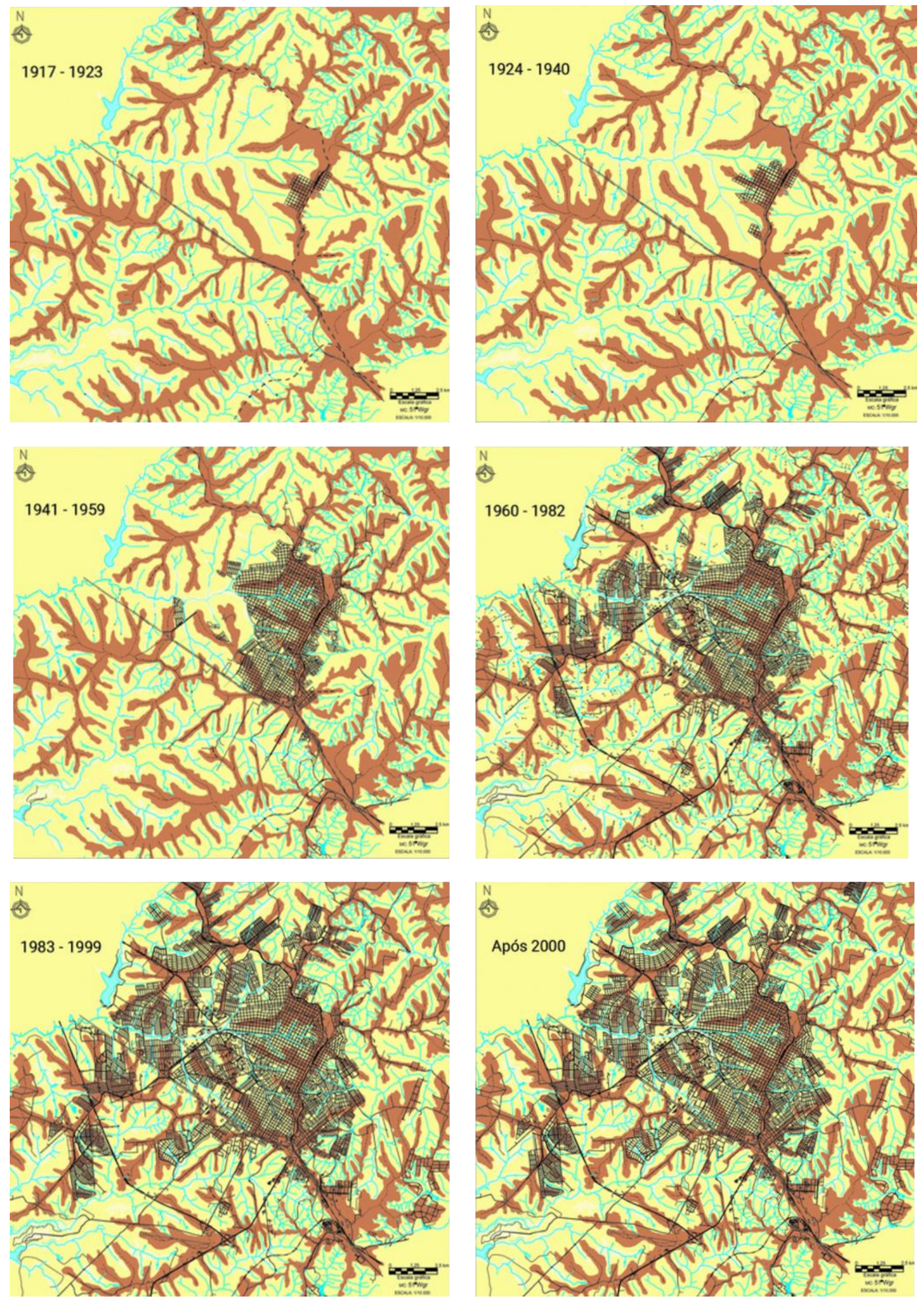

Fonte: Pedro (2008) e Nunes et al. (2006). Organizado por Nayara Rodrigues (2017). Disponível em: http://portaldoprofessor.fct.unesp.br:9000/. Acesso em 18 de novembro de 2018. 
Se articular uma política de desenvolvimento que levasse infraestrutura, saneamento, educação, saúde e outros serviços essenciais à população residente nos bairros mais afastados e distantes das áreas centrais já se mostrava complexo, o planejamento relacionado às áreas de preservação permanentes, às áreas verdes provenientes dos processos de parcelamento, à proteção dos cursos d'água e à qualificação dos fundos de vale, foi insipiente. Replicaram-se modelos de canalização dos córregos - transformando-os em galerias de escoamento - com esperadas supressão vegetal e abertura de vias em fundos de vale e, uma vez mais, os processos naturais envolvidos foram encapsulados e afastados dos olhares e da vida da população.

Em resumo, na atualidade, Presidente Prudente apresenta-se com uma mancha urbana dispersa, de tecido descontínuo, espaços livres - alguns qualificados e outros tantos desqualificados - rios invisíveis e muitos outros canalizados.

$\mathrm{O}$ crescimento e o adensamento de áreas urbanas vêm provocando diferentes mudanças no meio ambiental natural, tais como: aterramento de nascentes, impermeabilização dos solos, cortes e aplainamentos de vertentes, retificações e canalizações em rios e córregos. Essas modificações perturbam diretamente a paisagem e a dinâmica de bacias hidrográficas. Como consequência temos a ocorrência ou o agravamento dos chamados problemas ambientais urbanos (inundações, alagamentos, enxurradas, deslizamentos de terra, etc), gerados pela degradação do meio ambiente, muitas vezes em prol do "desenvolvimento e progresso". (MOROZ-CACCIA GOUVEIA e SILVA, 2017).

Sobre as ações de planejamento urbano relacionadas às questões rios e cidade, o poder público em Presidente Prudente continua canalizando seus córregos com placas de concreto, ou seja, impermeabilizando o canal e transformando os rios em grandes galerias de concreto que conduzem as águas mais rapidamente aos pontos mais baixos. As áreas de preservação em fundos de vale são compostas pelos sessenta metros - sendo trinta metros para cada margem do curso d'água - grafados na legislação e poucos deles apresentam espaços qualificados; alguns deles encontram-se até mesmo cercados, sem acesso.

Sobre os córregos que foram tamponados, algumas tentativas de criar espaços de lazer e socialização - aos moldes do Parque do Povo - foram testadas, mas carecem de manutenção e qualidade de projeto e, portanto, são pouco usufruídos e apropriados pelos moradores. 
A radiografia atual dos rios e córregos inseridos no atual perímetro urbano de Presidente Prudente pode ser acompanhada pela imagem a seguir (figura 41), na qual nota-se que grande parte dos rios localizados nas áreas mais centrais da cidade estão canalizados e tamponados, em especial os que compõem a bacia hidrográfica do Córrego do Veado.

Figura 41 - Situação atual dos rios e córregos no perímetro urbano de Presidente Prudente, SP.

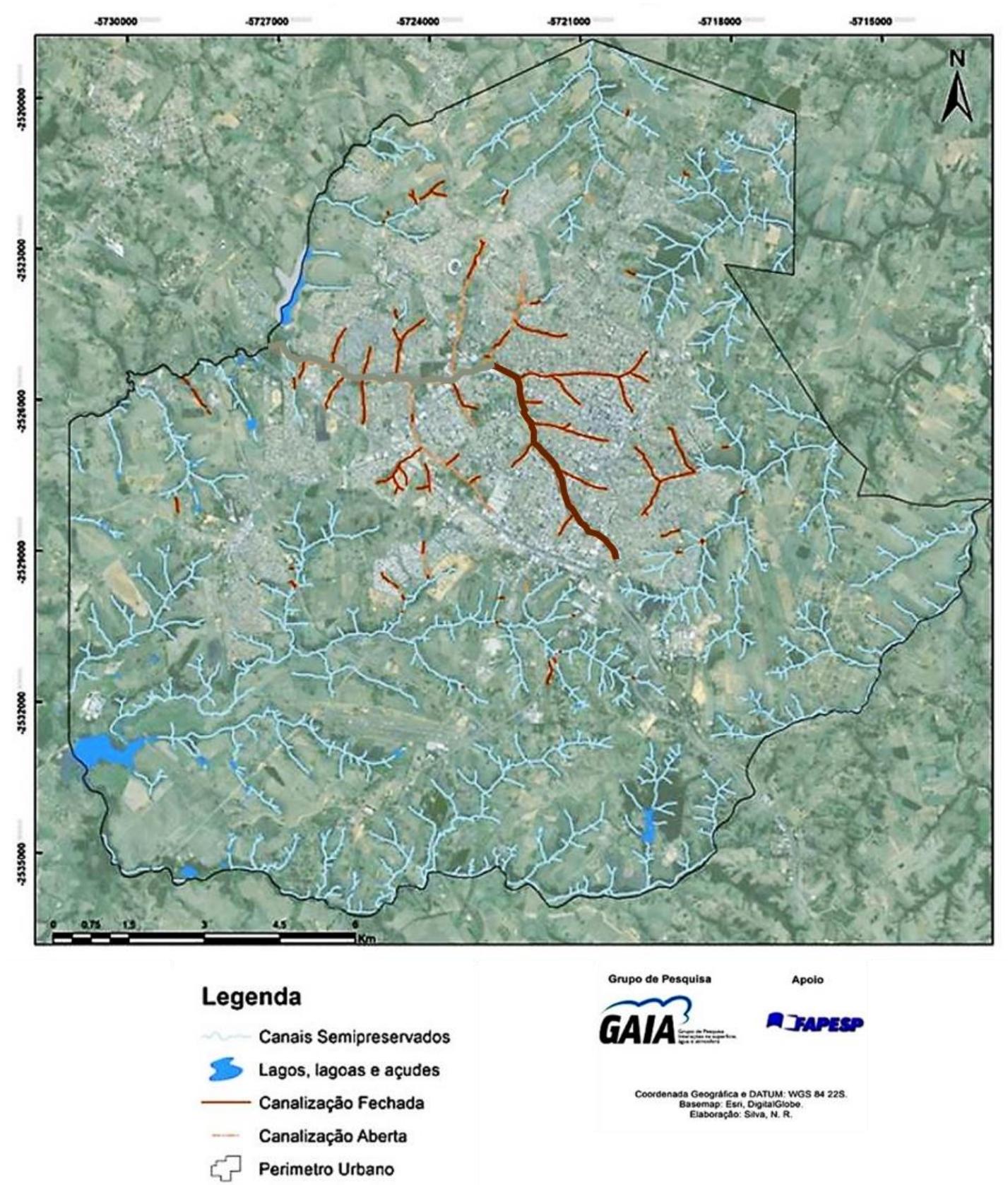

Fonte: Nunes et al (2017). Disponível em: http://portaldoprofessor.fct.unesp.br:9000/. Acesso em 18 de julho de 2018. 


\subsection{Legislação municipal atual}

Com relação à legislação atual, em âmbito municipal, o Plano Diretor passou por um processo de revisão e as demais leis a ele atreladas possuem especificidades que merecem atenção. Assim, no que tange a fundos de vale, permeabilidade do solo e rios e córregos, cabe pontuar algumas proposições presentes no Plano Diretor vigente - Lei no 230/2018, na Lei de Zoneamento do Uso e Ocupação do Solo - Lei 231/2018, na Lei de Parcelamento do Solo do Município - Lei no 232/2018 e na Lei do Sistema Viário - Lei no 233/2018.

\subsubsection{Plano Diretor de Presidente Prudente - Lei no 230/2018}

Em seu artigo sexto, ao citar os princípios que regem o Plano Diretor, o inciso sexto apresenta o seguinte texto: "preservação e recuperação do ambiente natural em harmonia com o desenvolvimento socioeconômico" (PRESIDENTE PRUDENTE, 2018a, grifo nosso).

Como informação adicional, mas de extrema relevância, cabe ressaltar que o Plano Diretor não apresenta uma cartografia das áreas verdes e dos espaços livres as praças e parques são enquadrados no zoneamento como "zona especial" do tipo "áreas de recreação e lazer"; assim como também não há uma cartografia das bacias hidrográficas e sub-bacias que compõem o município ou o perímetro urbano.

\subsubsection{Lei de Zoneamento do Uso e Ocupação do Solo - Lei no 231/2018}

O artigo vigésimo terceiro apresenta as Zonas de Preservação e Proteção Ambiental - ZPPA - que "destinam-se exclusivamente à preservação e proteção de mananciais, fundos de vales, nascentes, córregos, ribeirões, matas e vegetações nativas" (PRESIDENTE PRUDENTE, 2018b). Assim, estas áreas apenas podem sofrer alterações caso estas estejam relacionadas à infraestrutura urbana, saneamento e recreação e lazer.

A lei de Zoneamento traz ainda, no Anexo II (figura 42) os parâmetros e índices urbanísticos. Relacionado à escala do lote, as taxas de permeabilidade mínima dos lotes varia de $10 \%$ a $20 \%$; porém, é facultativa para edificações comerciais, de serviços, industriais ou mistos; ou seja, em grande parte da região 
central, que contempla a nascente do córrego do Veado, e onde mais ocorrem enchentes e inundações, não é obrigatório que um imóvel (comercial, industrial ou de serviços) possua áreas permeáveis para absorver água das chuvas e evitar uma sobrecarga ainda maior do sistema de captação de águas pluviais. Além disso, se houver subsolo, este pode ocupar $100 \%$ do lote se for totalmente enterrado, o que cria um paradoxo.

Figura 42 - Parâmetros e índices urbanísticos segundo a Lei de Zoneamento (Lei nำ231/2018) para Presidente Prudente-SP.

\section{ANEXO II}

PRESIDENTE PRUDENTE/ ZONEAMENTO

PARÂMETROS E ÍNDICES URBANÍSTICOS

\begin{tabular}{|c|c|c|c|c|c|c|c|c|c|}
\hline \begin{tabular}{c|} 
Zonas \\
Unidades
\end{tabular} & \begin{tabular}{|c|} 
Tamanho \\
Mínimo \\
do lote \\
(Metro \\
Quadrado)
\end{tabular} & $\begin{array}{c}\text { Fn } \\
\text { Mini } \\
\text { Nor } \\
\text { esq } \\
\text { (N) } \\
\text { Li }\end{array}$ & $\begin{array}{l}\text { nte } \\
\text { at do } \\
\text { e } \\
\text { nal/ } \\
\text { ina } \\
\text { tro } \\
\text { gar) }\end{array}$ & $\begin{array}{c}\text { Coeficiente de } \\
\text { Aproveitament } \\
\text { o Máximo } \\
\text { (Número) }\end{array}$ & \begin{tabular}{|c|}
$\begin{array}{c}\text { Taxa de } \\
\text { Ocupação } \\
\text { Máxima } \\
\text { (Percentagem) }\end{array}$ \\
\end{tabular} & $\begin{array}{l}\text { Recuo } \\
\text { Frontal } \\
\text { Mínimo } \\
\\
\text { (Metro } \\
\text { Linear) }\end{array}$ & $\begin{array}{c}\text { Área mínima } \\
\text { de Terreno } \\
\text { por Unidade } \\
\text { Habitacional } \\
\text { (Metro } \\
\text { Quadrado) }\end{array}$ & \begin{tabular}{|c|} 
Taxa de \\
Permeabilida \\
de \\
Mínima \\
\\
(Percentagem)
\end{tabular} & $\begin{array}{l}\text { Gabarito } \\
\text { de Altura } \\
\text { Máxima } \\
\text { (Número) }\end{array}$ \\
\hline ZRI & $\begin{array}{c}300 \% \\
250(11) \\
\end{array}$ & 12 & 14 & 1 & 70 & 4 & 160 & 20 & $2(8)$ \\
\hline $\mathrm{ZR} 2$ & 250 & 10 & 12 & 2 & 70 & 4 & 60 & 10 & $2(8)$ \\
\hline ZR3 & 250 & 12 & 14 & $6(10)$ & 70 & 4 & 20 & 10 & Livre \\
\hline ZR4 & $\begin{array}{c}160 / 125 \\
(12)\end{array}$ & 08 & 12 & 2 & 70 & $4 / 2(9)$ & 60 & 10 & $2(8)$ \\
\hline ZCSI & 500 & 15 & 19 & $6(10)$ & $80(1) / 70(2)$ & $0(3) / 4(4)$ & 10 & $0(5) / 10(6)$ & Livre \\
\hline $\mathrm{ZCS} 2$ & - & - & - & $6(10)$ & $80(1) / 70(2)$ & $0(3) / 4(4)$ & 10 & $0(5) / 10(6)$ & Livre \\
\hline ZCS3 & - & - & - & (7) & 70 & $0(3) / 4(4)$ & (7) & $0(5) / 10(6)$ & $3(8)$ \\
\hline $\mathrm{ZII}$ & 500 & 15 & 19 & 4 & 70 & 4 & 20 & 20 & Livre \\
\hline $\mathrm{ZI} 2$ & 1000 & 20 & 30 & 2 & 60 & 10 & - & 20 & Livre \\
\hline
\end{tabular}

Observaçōes:-

(1) $80 \%$ (oitenta por cento) de taxa de ocupação máxima para edificaçôes comerciais, serviços, industriais ou mistas;

(2) $70 \%$ (setenta por cento) é a taxa de ocupação máx ima para edificaçôes exclusivamente residenciais:

(3) é facultativo o recuo frontal para edificaçồes comerciais, serviços, industriais ou mistas;

(4) é obrigatório o recuo frontal mínimo de 4 (quatro) metros para edificaçôes exclusivamente residenciais:

(5) é facultativa a taxa de permeabilidade para edificaçðes comerciais, serviços, industriais ou mistos;

(6) é obrigatória a taxa de permeabilidade mínima de $10 \%$ (dez por cento) para edificaçốes exclusivamente residenciais;

(7) adotam-se os índices urbanísticos da zona de maior coeficiente de aproveitamento;

(8) quando a área de estacionamento se constituir de um pavimento e não tiver outro tipo de uso incluído, não será computado para efeito de gabarito de altura;

(9) quando forem lotes de interesse social, ou lotes com tamanho mínimo inferior ao Anexo II e desde que sejam lotes com matrícula anterior a 1996, o recuo frontal mínimo é de 2,00 metros;

(10) outorga onerosa do direito de construir, podendo o coeficiente de aproveitamento ser acrescido em 2 , podendo atingir o máximo de 8;

(11) índices reduzidos para o tamanho do lote, permitidos somente para outorga onerosa do direito de parcelar na ZRI;

(12) para interesse social com utilização da Lei Federal $n^{\circ} 6.766 / 1979$ e com interesse e participaçâo do município.

Obs.: Subsolo, somente para estacionamento, poderá ocupar $100 \%$ do lote.

Fonte: Lei municipal no 231/2018, modificado pelo autor, grifo nosso. 


\subsubsection{Lei de Parcelamento do Solo do Município - Lei no 232/2018}

A lei municipal de parcelamento do solo apresenta na Seção I, sobre os requisitos para a aprovação de loteamentos, em seu artigo décimo segundo, inciso IV:

IV - ao longo das áreas de preservação de fundo de vales, junto às águas correntes, faixa de linhas de transmissão e faixa de domínio público das rodovias, ferrovias e viadutos, será obrigatória a implantação e execução de uma via marginal, conforme estabelecido na Lei do Sistema Viário Básico (PRESIDENTE PRUDENTE, 2018c, grifo nosso)

Além disso, o inciso $\mathrm{Vl}$, do mesmo artigo, em sua alínea $\mathrm{k}$, exige que os loteamentos sejam contemplados com obras de infraestrutura, dentre as quais: "cercamento das áreas de APP, áreas institucionais, áreas de lazer e áreas verdes" (PRESIDENTE PRUDENTE, 2018c, grifo nosso).

O artigo 39 estipula ainda a reserva de áreas públicas junto aos fundos de vale dos córregos Cedro e Cedrinho - com $60 \mathrm{~m}$ do leito - e também para as lagoas do Balneário da Amizade e a lagoa de captação do Ribeirão Santo Anastácio - com $150 \mathrm{~m}$ a partir do espelho d'água. Estes são os únicos córregos que apresentam ganho de área pública em relação aos valores já estipulados pela legislação federal; e isso se deve ao fato de que são áreas mananciais de abastecimento e reserva de água para os habitantes de Presidente Prudente, uma vez que toda a água consumida na cidade vem da captação superior em rios e lagoas.

\subsubsection{Lei do Sistema Viário - Lei no 233/2018}

A lei do sistema viário municipal estabelece, em seu artigo quinto que "os fundos de vale, rios, córregos ou ribeirões deverão ser margeados por via marginal, respeitando-se os limites das áreas públicas de preservação, tanto nas áreas urbanizadas, como nas urbanizáveis" (PRESIDENTE PRUDENTE, 2018d, grifo nosso). Consta ainda, na mesma lei, em seu anexo I, que as vias marginais são compostas por uma pista de rolamento com nove metros de largura e passeios com seis metros totais de largura, caracterizando a via marginal com um total de quinze metros.

No decorrer deste capítulo abordou-se o histórico de formação do município e a expansão urbana de Presidente Prudente, evidenciando fatores e 
processos de planejamento responsáveis pela forma urbana e relações rios e cidade que temos atualmente. Se, por um lado, temos o surgimento da cidade no espigão das terras, distante dos córregos e pouco relacionado a eles, por outro, a expansão urbana revela um contato que passou a ser permanente, apesar das rupturas em suas relações: Presidente Prudente tamponou muitos de seus cursos d'água invisibilizando-os - e continua canalizando todos aqueles que se encontram em meio urbano.

A diretriz de preservar e recuperar o meio natural, presente no plano diretor, apresenta outro paradoxo: faz-se o cercamento das APPs com o intuito de preserválas, mas canalizam-se os córregos, transformando-os em grandes galerias de escoamento das águas. $\mathrm{E}$ a presença das vias marginais, que poderiam trazer estas áreas mais naturalizadas para um contato mais próximo com a população, fazendo-a ver e entender os processos naturais, acaba por contribuir para seu afastamento, por se apresentarem como vias preferenciais para veículos e que apresentam cercas em torno das áreas de preservação. Os processos naturais continuam distantes dos olhos da população e os projetos de vias marginais e sistemas de recreação nessas áreas carecem de qualidade projetual.

Nem a experiência bem-sucedida de ter um parque linear em um fundo de vale, como é o caso do Parque do Povo, uma paisagem dotada de espaços qualificados e presente na memória da população - e que representou um contraponto a tudo o que vinha sendo realizado nos fundos de vale à época de sua construção -, faz com que o córrego deixe de carregar a culpa das inundações que é, na verdade, fruto dos processos de planejamento e ocupação da bacia como um todo: impermeabiliza-se as cabeceiras, canalizam-se os corpos de água urbanos, constróise galerias pluviais e avenidas de fundo de vale e, à primeira chuva - e com ela enchentes e inundações - a culpa continua sendo do grande volume de chuvas em pouco tempo e do canal do córrego que não possui dimensionamento adequado para o montante de águas pluviais. Em Presidente Prudente, no trecho do fundo de vale do Córrego do Veado, é o próprio parque é que inunda - como é de se esperar - ainda assim, preferiu-se tamponar o córrego em todo seu trecho que percorre o Parque do Povo e vários de seus afluentes.

O próximo capítulo tem como recorte a bacia hidrográfica do Córrego do Veado, contemplando os espaços livres e os conflitos entre meio físico natural e ocupação do território que levaram aos processos de congruência e ruptura entre rios 
e cidade que operam como fio condutor deste trabalho. Também será abordada uma proposta metodológica de trabalho com projetos de paisagem para os espaços livres da referida bacia. 


\section{CAPÍTULO IV - PRESIDENTE PRUDENTE: BACIA HIDROGRÁFICA DO CÓRREGO DO VEADO}

Nos capítulos anteriores, a explanação do contexto histórico de surgimento do município de Presidente Prudente e seu desenvolvimento ao longo das décadas foram relacionados às diferentes políticas de planejamento e de produção do espaço urbano. Essa estratégia de trabalho apresentou ainda o contexto da legislação atual relacionada às questões dos rios urbanos e áreas de proteção permanentes. Este capítulo pretende estruturar essa argumentação - através de imagens históricas como fotografias e imagens de satélite, relacionando-as às referências teóricas do campo disciplinar da Paisagem.

Desse modo, se constrói uma narrativa acerca da transformação dos corpos d'água e ocupação dos fundos de vale inseridos na bacia hidrográfica do Córrego do Veado e seu estado atual, evidenciando os conflitos e propondo uma ressignificação - que será apresentada no quinto capítulo - entre rios e cidade, por intermédio de um planejamento sistêmico com a paisagem.

A partir de uma perspectiva contemporânea de se pensar o planejamento das cidades, utilizando-se de estratégias menos conflituosas - como as infraestruturas verde e azul - procura-se construir lugares para sociabilização das pessoas, colocando-as em contato com os processos que sustentam a vida, educando o olhar sobre a paisagem.

\subsection{Bacia Hidrográfica do Córrego do Veado: uma radiografia}

Conforme descrito no capítulo III, o município de Presidente Prudente possui seu território inserido em duas grandes bacias, que pertencem a duas diferentes Unidades de Gerenciamento de Recursos Hídricos (UGRHI) no Estado de São Paulo: a do Rio do Peixe - UGRHI 21 - e a Pontal do Paranapanema - UGRHI 22. O surgimento do núcleo urbano e os processos de desenvolvimento levaram à maior ocupação das áreas localizadas a oeste deste divisor das bacias, o que coincide, em Presidente Prudente, com o traçado da linha férrea Sorocabana, instalada sobre o espigão do relevo. Assim, as nascentes de alguns dos córregos que compõem as duas bacias localizam-se em área urbana. 
A Bacia Hidrográfica do Córrego do Veado (figura 43) possui aproximadamente $29,61 \mathrm{~km}^{2}$ de extensão territorial, segundo Moroz-Caccia Gouveia e Gouveia (2015), e corresponde a uma sub-bacia da Bacia Hidrográfica do Rio Santo Anastácio, que é uma das bacias que compõe a UGRHI 22 - Pontal do Paranapanema.

Apresenta a peculiaridade de estar, atualmente, totalmente incorporada ao meio urbano de Presidente Prudente (figura 43); foi sobre seu território que se deu o maior desenvolvimento da mancha urbana, apresentando diversas relações conflituosas entre o meio físico e estes processos de ocupação. Sendo um caso exemplar dessa situação, foi escolhida como recorte para este capítulo e foi a responsável por dar origem a esta pesquisa.

Figura 43 - Área da Bacia Hidrográfica do Córrego do Veado.

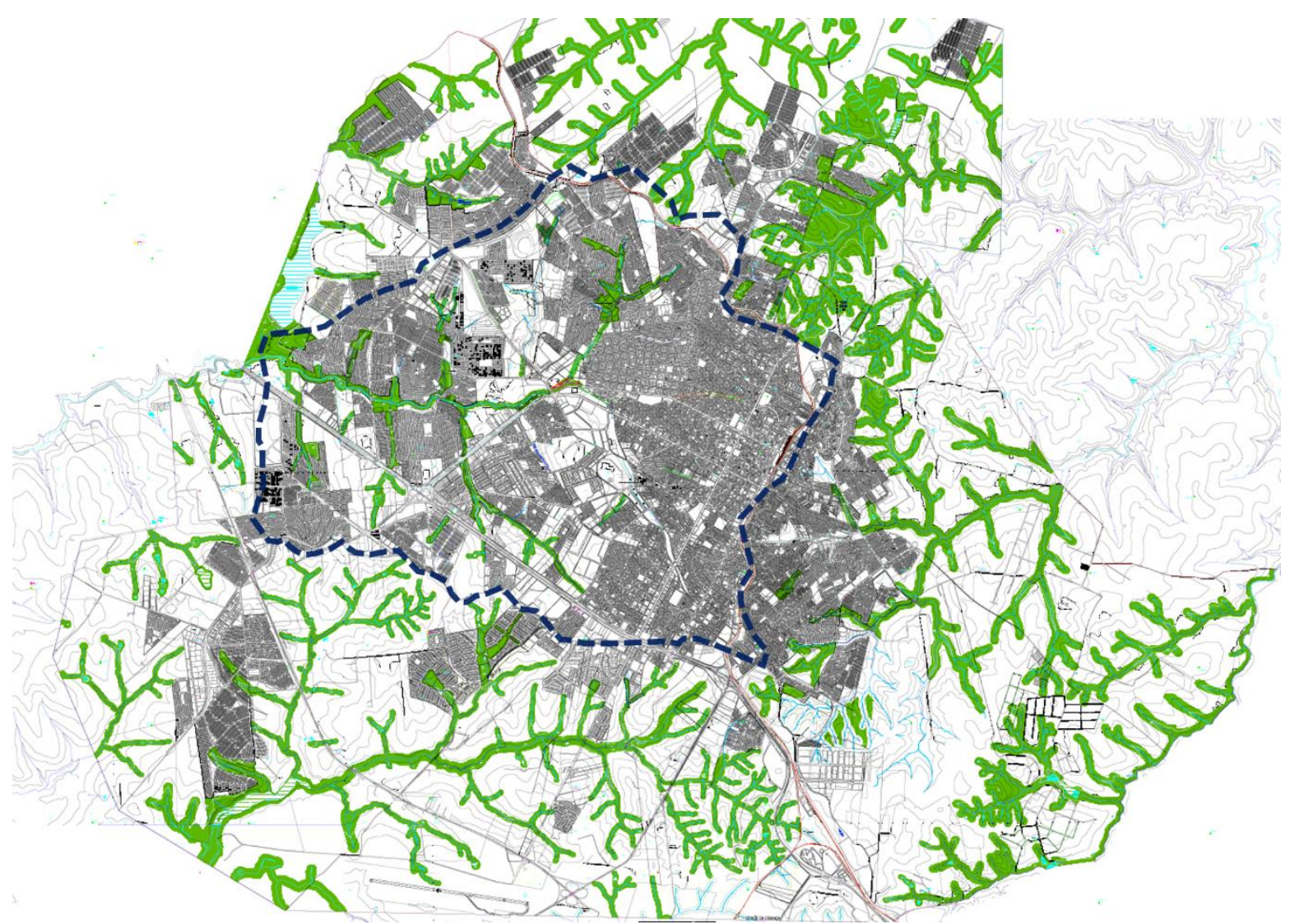

Área da Bacia Hidrográfica do Córrego do Veado delineada dentro do perímetro urbano (neste caso, do Plano Diretor de 2008) de Presidente Prudente, juntamente com as áreas de proteção permanentes (APP) indicadas pelo mapa de Zoneamento (2008) do município. Observa-se como são reduzidas as áreas de proteção no interior da bacia hidrográfica do Córrego do Veado. Fonte: Prefeitura Municipal de Presidente Prudente, 2012, modificado pelo autor.

Uma vez que estes processos de ocupação aconteceram em diferentes épocas nos últimos 100 anos, portanto presenciando diferentes ações de 
planejamento e estando - ou não, a depender do período - sob diferentes amparos legislativos ${ }^{46}$, a radiografia atual da Bacia do Córrego do Veado (figura 44) apresenta, segundo Silva e Moroz-Caccia Gouveia (2017), os seguintes dados: 91\% de seus cursos d'água sofreram intervenção e, portanto, apenas 9\% deles apresentam-se semi-preservados ${ }^{47}$. Daqueles que sofreram intervenção, 63\% apresentam-se canalizados e tamponados - invisíveis na paisagem - e $28 \%$ são compostos de cursos d'água que foram retificados e canalizados em galerias abertas.

Assim, a figura 44 apresenta o estado atual dos córregos que compõem a Bacia Hidrográfica do Córrego do Veado e seus principais cursos fluviais. Através da imagem é possível verificar o quão urbanizado e ocupado é o território da bacia hidrográfica e como grande parte de seus córregos encontram-se canalizados.

Figura 44 - Atual estado dos córregos que compõem a Bacia Hidrográfica do Córrego do Veado em Presidente Prudente-SP.

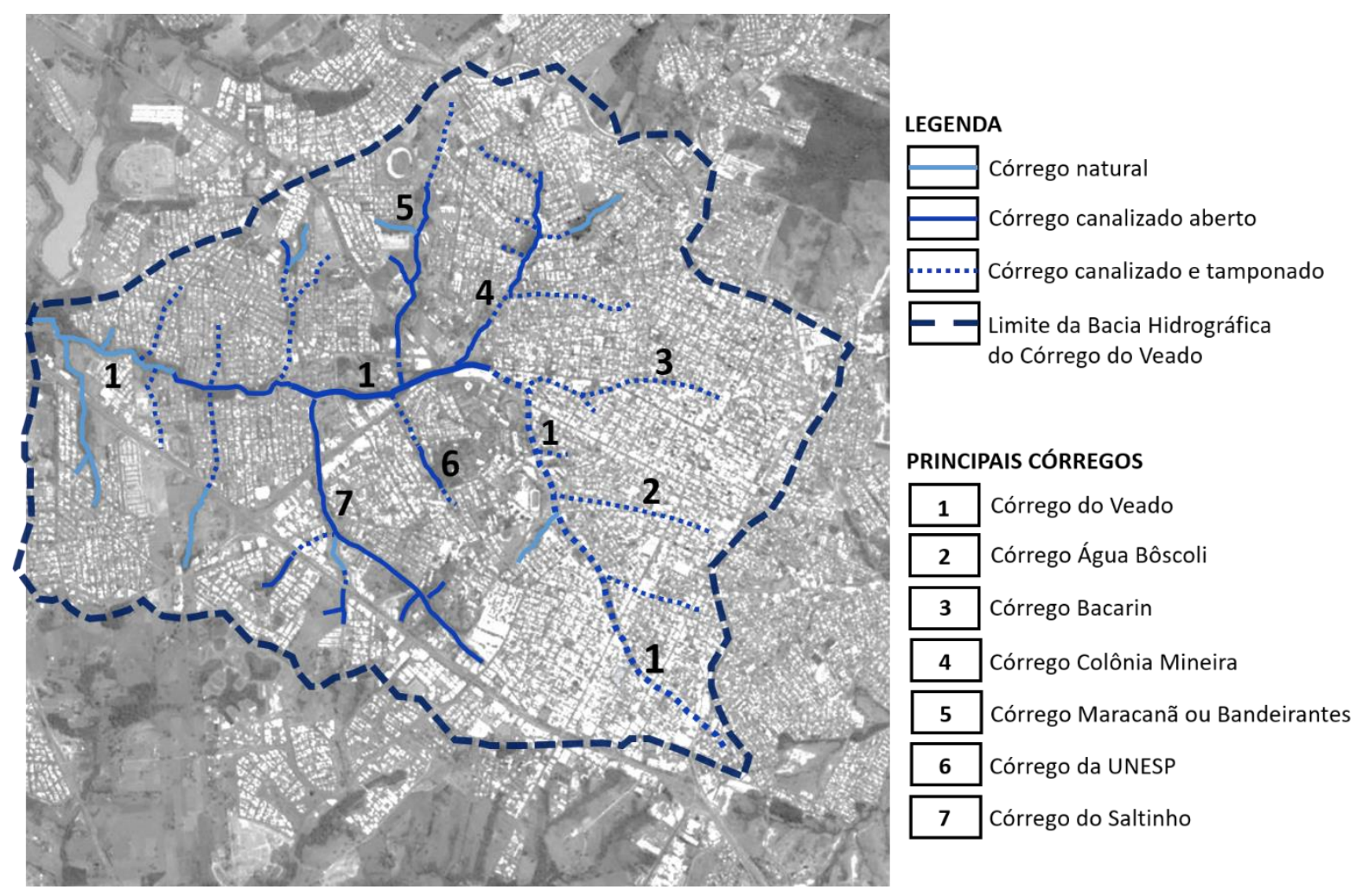

Fonte: Google Earth (2019), modificado pelo autor, com base em Nunes et al (2017).

Como se procura evidenciar no decorrer deste capítulo, todos os córregos situados nas regiões mais centrais da cidade - portanto na porção leste da sub-bacia

${ }^{46}$ Conforme apresentado no capítulo III deste mesmo trabalho.

${ }^{47}$ Não foram canalizados e apresentam suas águas correntes em áreas ainda permeáveis. 
- e que são afluentes do Córrego do Veado, encontram-se invisibilizados, ocultos, tamponados, transformados em galerias subterrâneas. O próprio córrego que dá nome à bacia apresenta-se tamponado em um trecho com pouco mais de três quilômetros, da nascente até o ponto próximo ao encontro de suas águas com as do córrego Colônia Mineira, seu afluente. Antes de tornar-se completamente visível, o Córrego do Veado recebe águas de, aproximadamente, outros quatro afluentes: três deles - entre eles o Água Bôscoli - desaguam em seu leito canalizado sob galerias abaixo do Parque do Povo e o quarto, Córrego Bacarin, encontra suas águas embaixo do estacionamento do Prudenshopping ${ }^{48}$, logo após a grande galeria aberta - que serve como um ponto de extravasamento e respiro para a galeria do Córrego do Veado - construída na praça Oscar Figueiredo Filho.

Os cursos fluviais que aportam suas águas no Veado em regiões posteriores ao Prudenshopping apresentam trechos ora tamponados ora abertos, e em alguns deles ainda naturalizados - conforme aumenta a distância em relação às regiões centrais. Como veremos neste capítulo, os trechos dos córregos naturalizados ainda apresentam esta característica apenas porque ou não existiram recursos financeiros para as obras de "urbanização de fundos de vale" - como se refere o poder público municipal às obras de canalização dos córregos em meio urbano - ou porque o Ministério Público do Meio Ambiente interveio e conseguiu estabelecer a salvaguarda daquelas paisagens, como demonstra Fagundes (2018).

O fato é que a bacia do Córrego do Veado, por estar inserida totalmente em uma área urbana, apresenta grande extensão de seu território completamente impermeabilizado. Segundo as pesquisas de Silva e Moroz-Caccia Gouveia (2017), $75 \%$ da superfície desta bacia hidrográfica encontra-se nessa situação. A figura 45 apresenta, através de imagens de satélites, uma vista da cidade Presidente Prudente na qual é possível verificar o nível de ocupação e impermeabilização dentro da bacia. 
Figura 45 - Vista da cidade de Presidente Prudente, contendo os limites da Bacia Hidrográfica do

Córrego do Veado, demarcação do núcleo central originário - em amarelo - e da altitude em diferentes pontos da bacia. Os três pontos em azul representam nascentes dos córregos atualmente invisíveis porque foram canalizados e tamponados na região central da cidade.

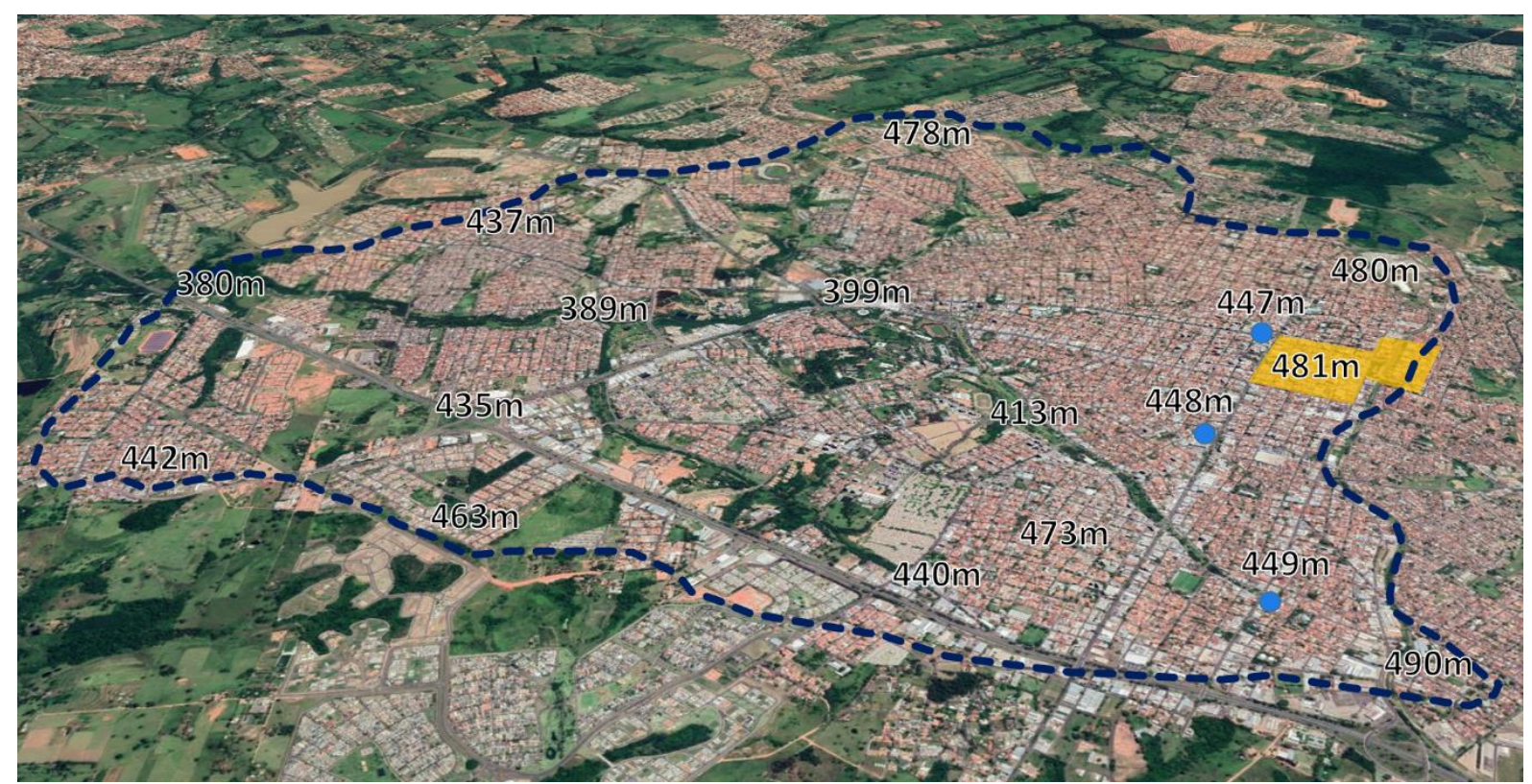

Fonte: Google Earth (2019) modificado pelo autor.

A figura 45 traz ainda a altitude em diversos pontos dentro área analisada, evidenciando um desnível que chega a 110m: dos pontos mais altos - por volta de $490 \mathrm{~m}$ - ao mais baixo - 380m, localizado na confluência dos Córregos do Veado e Limoeiro, ponto no qual termina o recorte da bacia hidrográfica em questão. Evidenciase, pela imagem, a instalação histórica do núcleo central e linha férrea sobre o espigão do relevo e demonstra-se como a expansão urbana ocupou e impermeabilizou grande parte dos fundos de vale mais próximos à região central, além de tornar esses cursos fluviais e seus processos naturais invisíveis.

Como relatado no terceiro capítulo deste trabalho, a partir das novas legislações de proteção aos rios, córregos e suas faixas marginais e também da instituição de legislação específica sobre o parcelamento do solo urbano, promulgadas em âmbito federal a partir das décadas de 1960 e 1970. Esse momento histórico assegura nova fisionomia para os córregos da cidade, a ocupação dos fundos de vale passou a ter uma nova aparência, com a presença de espaços livres e maiores áreas permeáveis amparadas por lei. Na figura acima são nítidas as diferenças entre a região central - cinza - e as demais regiões, marcadas por veios e 
capilares "verdes" em meio a trama urbana de uma bacia que se encontra completamente inserida na cidade.

Porém, por mais que existam as áreas de preservação permanentes e áreas verdes criadas em cada processo de parcelamento de glebas, a impermeabilização do solo dentro da Bacia é muito alta e grande parte de seus córregos encontram-se canalizados e tamponados por processos de planejamento realizados, em Presidente Prudente, ao longo dos últimos setenta anos - e ainda em processo. Como abordado no primeiro capítulo, os cursos d'água em meio urbano, quando são perceptíveis, são como galerias que devem conduzir a água das chuvas e as águas servidas para fora da cidade no menor tempo possível. A cidade continua sendo vista como parte não integrante da natureza e seus processos.

Mas os rios estão ali, o relevo está ali, as chuvas continuam e as tempestades também. Se as novas paisagens evidenciam a construção de uma materialidade sobre o território, estas paisagens explicitam o contato entre um todo construído e a chamada natureza. Assim, além das enchentes que ocupam naturalmente as várzeas dos rios e córregos - lembrando que as áreas de várzeas continuam a existir mesmo após a canalização ou ocupação das margens dos cursos fluviais - a impermeabilização do solo e dos rios acarreta frequentes enxurradas, inundações e alagamentos e a declividade do relevo contribui para ampliar ainda mais a velocidade das águas sobre o solo impermeabilizado. O rio, naturalmente, toma o espaço de sua várzea.

A figura 47 apresenta, por meio de uma série de fotografias - indicadas na figura 46, a "memória dos rios" - neste caso como referência aos processos de enchentes que ocupam o leito dos rios e córregos, muitos deles canalizados e também tamponados - na cidade de Presidente Prudente. A primeira imagem mostra a localização e a referência para cada fotografia apresentada na segunda imagem. 
Figura 46 - Bacia Hidrográfica do Córrego do Veado. Os números indicam a localização dos pontos nos quais foram realizadas as fotografias.

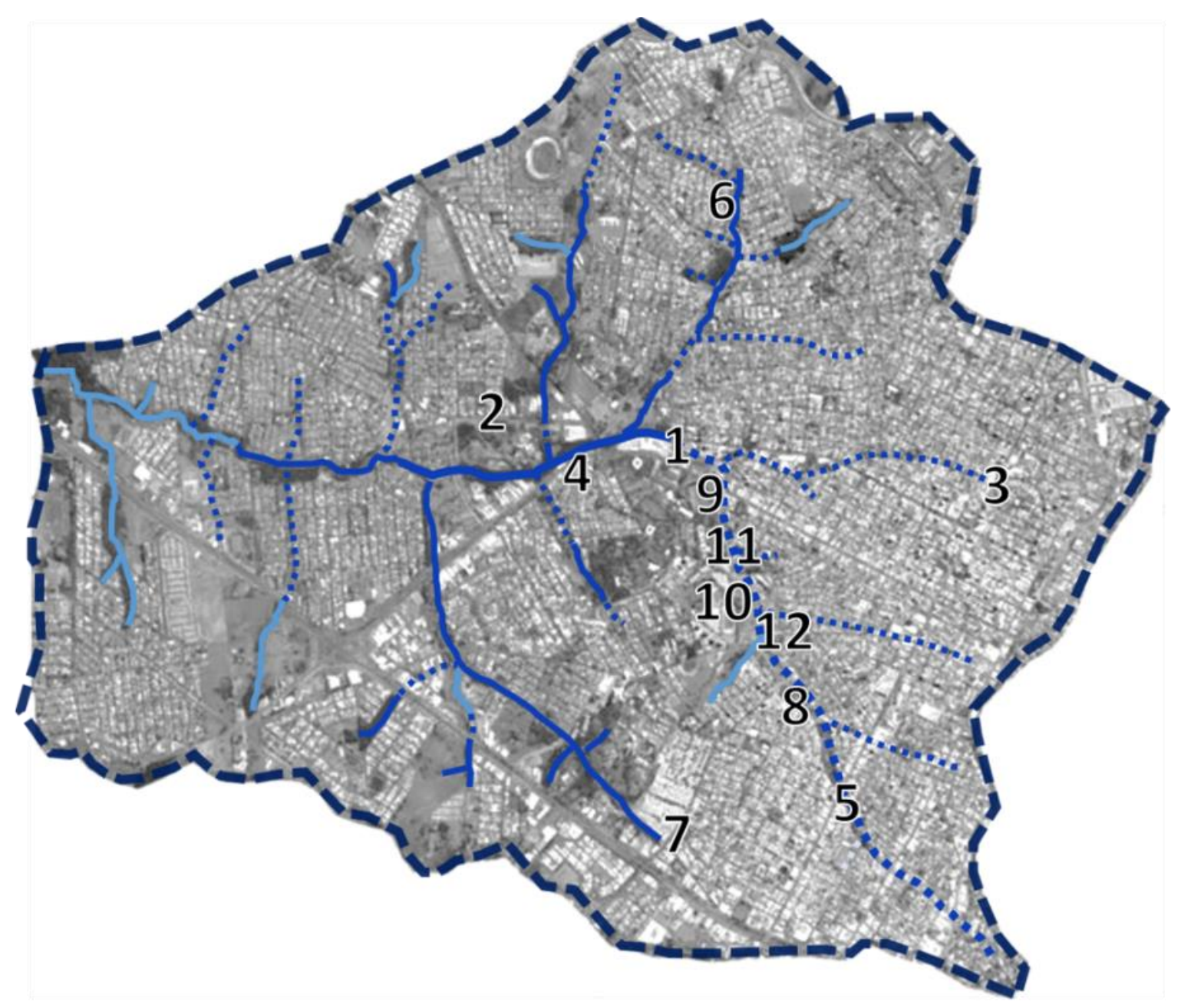

Fonte: Google Earth (2019), modificado pelo autor. 
Figura 47 - Compilado de fotografias que retratam as questões das enchentes, inundações e alagamentos em Presidente Prudente, na Bacia Hidrográfica do Córrego do Veado.
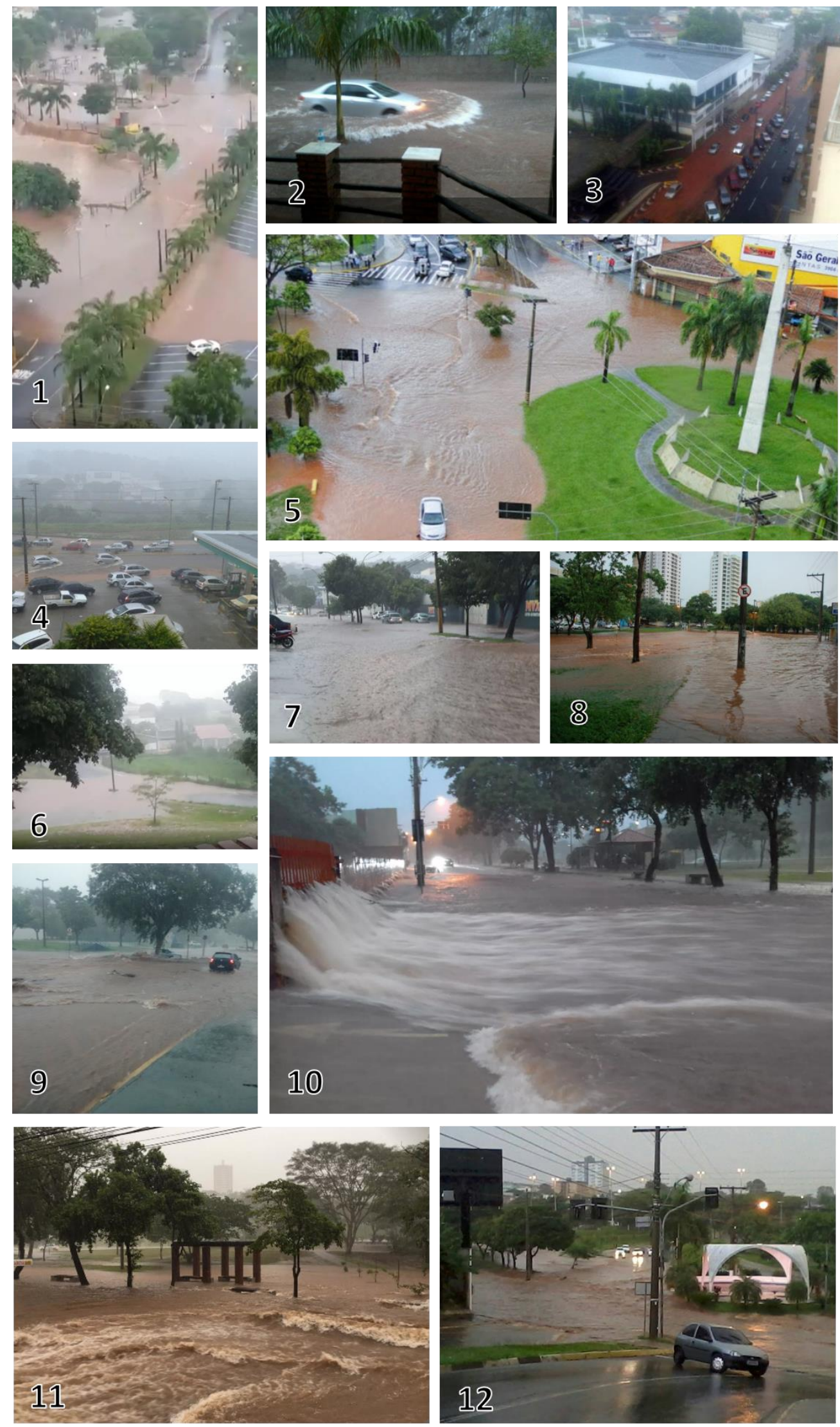

Fonte: a descrição e fonte das imagens encontram-se listadas abaixo. 
1. Inundação na galeria aberta localizada na Praça Oscar Figueiredo Filho e no estacionamento do Prudenshopping, 2020. Neste local o Córrego Bacarin aporta suas águas no Córrego do Veado. A galeria aberta neste ponto serve como respiro e extravasor para o Córrego do Veado. Fonte: frame de um vídeo. Divulgação: Youtube. Disponível em: https://www.youtube.com/watch?v=Kg106h6nDbk

2. Alagamento em trecho da Avenida Ana Jacinta, 2012, em virtude do grande volume de chuvas em um intervalo pequeno de tempo. Fonte: Portal Prudentino. Disponível em: https://www.portalprudentino.com.br/noticia/noticias/presidente-prudente-noticias/chuva-provocavarios-pontos-de-alagamentos-em-pp

3. Avenida Cel Marcondes, em frente a APEA, 2012. Pela análise de mapas mais antigos e fotografias históricas, esta é a região - atualmente muito impermeabilizada - de nascentes do Córrego Bacarin e onde também se tem o primeiro registro de sua canalização. Fonte: Portal Prudentino. Disponível em: https://www.portalprudentino.com.br/noticia/noticias/presidenteprudente-noticias/chuva-provoca-varios-pontos-de-alagamentos-em-pp

4. Alagamento em trecho da Avenida Manoel Goulart, 2012. Fonte: Portal Prudentino. Disponível em: https:/www.portalprudentino.com.br/noticia/noticias/presidente-prudentenoticias/chuva-provoca-varios-pontos-de-alagamentos-em-pp

5. Inundação no Parque do Povo, no cruzamento com a Avenida Cel. José Soares Marcondes, 2019, em trecho no qual o Córrego do Veado encontra-se canalizado e tamponado desde o final da década de 1970. Fonte: Portal Prudentino. Disponível em: https://www.portalprudentino.com.br/noticia/noticias/presidente-prudente-noticias/parque-dopovo-pode-sofrer-sobrecarga-no-escoamento-de-agua

6. Enchente sobre o Parque São Mateus, 2020, em região de afluente do Córrego Colônia Mineira, que se encontra canalizado neste ponto. Fonte: Foto de Edneia. Divulgação: G1. Disponível em: https://g1.globo.com/sp/presidente-prudente-regiao/noticia/2020/01/13/temporalprovoca-alagamentos-e-enxurrada-arrasta-carros-no-parque-do-povo-em-presidenteprudente.ghtml

7. Alagamento em trecho da Avenida da Saudade, 2017, em região impermeabilizada próxima à nascente principal do Córrego do Saltinho. Fonte: Foto de Plínio Martins Garcia. Divulgação: G1. Disponível em http://g1.globo.com/sp/presidente-prudenteregiao/noticia/2017/01/temporal-causa-alagamentos-em-vias-de-presidente-prudente.html

8. Enchente no Parque do Povo, 2018, na região entre as avenidas Cel Marcondes e Saudade em trecho no qual o Córrego do Veado encontra-se canalizado e tamponado desde o final da década de 1970. Fonte: O Imparcial. Disponível em: http://www.imparcial.com.br/noticias/prefeitura-confirma-vinda-de-fonplata-na-proximasemana,24647

9. Inundação na região do Parque do Povo, sem data. Apesar do Córrego estar tamponado e canalizado dentro do parque, é a avenida 14 de Setembro - antiga pista Norte - que recebe maior volume de águas. Como será apresentado em tópico posterior, o curso natural do Córrego do Veado passava sob o local em que foi aberta a avenida e a retificação e canalização do Córrego levaram-no para "dentro" da região que viria a ser parque - e que, em muitos trechos, encontra-se em cota mais elevada que a avenida. Reprodução: Redes sociais. Site: Facebook.

10. Parque do Povo, na região de encontro das águas do Córrego Água Bôscoli com as do Córrego do Veado, 2020. "A cascata" representa o grande volume proveniente da região central da cidade - e que é trazido pela galeria do Córrego Água Bôscoli - que extravasou no terreno ao lado do Parque do Povo, no único e curto trecho no qual o córrego encontrase destamponado. Fonte: Foto de Valmir Custódio/TV Fronteira. Divulgação: G1. Disponível 
em: $\quad$ https:/g1.globo.com/sp/presidente-prudente-regiao/noticia/2020/01/14/prefeitura-depresidente-prudente-ignora-sentenca-transitada-em-julgado-que-lhe-impos-obrigacoes-paraenfrentar-enchentes-no-parque-do-povo.ghtml

11. Enchente no Parque do Povo, 2020. Fonte: Foto de Wellington Roberto. Divulgação: G1. Disponível em: https:/g1.globo.com/sp/presidente-prudente-regiao/noticia/2020/01/13/temporalprovoca-alagamentos-e-enxurrada-arrasta-carros-no-parque-do-povo-em-presidenteprudente.ghtml

12. Parque do Povo, cruzamento da Avenida Celestino José Figueiredo com a Avenida 14 de Setembro, sem data. Reprodução: Facebook.

Em resumo, uma cidade na qual a população pouco enxerga suas águas no dia-a-dia, mas as veem, a cada episódio, de moderada ou intensa chuva. As fotografias elucidam que não são apenas as áreas de várzeas que sofrem enchentes - um processo que é natural - mas também são diversos os pontos de alagamento, processo que expressa o conflito com o meio físico, ou inundações pela cidade em virtude do alto grau de impermeabilização do solo. Somados à impermeabilização, a alta taxa de ocupação dos fundos de vale, a transformação dos rios em galerias de rápido escoamento e zero de absorção - uma vez que são construídas com materiais impermeáveis - coloca-se em primeiro plano nessa dissertação os córregos invisibilizados por processos de planejamento decorrentes de uma época e corrente de pensamentos pautada em "solucionar os problemas da cidade" através de projetos para "sanear os rios" e "urbanizar os fundos de vale" fazem de Presidente Prudente mais um exemplo dos muitos encontrados pelas cidades brasileiras. Como relata Francisco (2012):

[...] tal ocupação [do solo] aconteceu de modo a negar os córregos da microbacia do Córrego do Veado e quando da oportunidade de reurbanizá-los, na década de 1970, a solução encontrada foi a canalização -com calhas de concreto -e o aterramento [...].

A reurbanização dos fundos de vale foi concebida como respostas técnicas, ora para atender a necessidades de expansão urbana, ora como resposta às pressões políticas -e imobiliárias -e não como resultado de um planejamento físico e territorial urbano de âmbito global. (FRANCISCO, 2012, p 9)

Ainda que o Córrego do Veado e muitos de seus afluentes tenham sido canalizados e tamponados, a construção do Parque do Povo representa um movimento de inflexão, com a diretriz dada pelo Plano Diretor elaborado pelo CPEU de salvaguardar a paisagem nos fundos de vale. Assim, as enchentes ocorrem no parque e este cumpre, em partes, sua função de área alagável e permeável - a situação com certeza seria muito pior se todo o fundo de vale e a área de preservação 
permanente tivessem sido ocupados como historicamente ocorreu na cidade. Todavia, a região central da cidade, localizada nos pontos mais altos do relevo dentro da bacia, apresenta-se muito impermeabilizada, além de seus córregos estarem canalizados e tamponados, essa situação contribui para que as águas cheguem em grande volume e alta velocidade nas partes mais baixas. A conclusão está nas fotografias apresentadas acima: as inundações são fruto de um processo construído e, no limite, planejado.

\subsection{Relações rio - cidade e espaços livres: do passado à configuração atual}

Este tópico mostra a relação da cidade com seus rios e espaços livres - desde seu surgimento até a atualidade -, evidenciando por mapas e imagens de satélite das décadas de 1970 e 1990 como se sucedeu a ocupação dos fundos de vale, supressão de córregos, impermeabilização do solo e canalização de córregos. Uma lógica que ainda é uma política de planejamento vigente no município.

\subsubsection{Surgimento do município até a década de $\mathbf{1 9 5 0}$}

Do surgimento das duas vilas que deram origem à cidade de Presidente Prudente até os anos de 1930, a cidade cresceu e se desenvolveu nas proximidades da estação central e linearmente à linha férrea (figura 48), que era o eixo estruturador do desenvolvimento à época. Assim, por estar instalada no espigão das terras, a cidade tinha pouca relação direta com os rios de seu território. 
Figura 48 - Armazém e pátio da Estrada de Ferro Sorocabana, 1941. À direita, ao fundo, trecho da Vila Marcondes e Indústrias Matarazzo, que se instalariam na cidade em 1937.

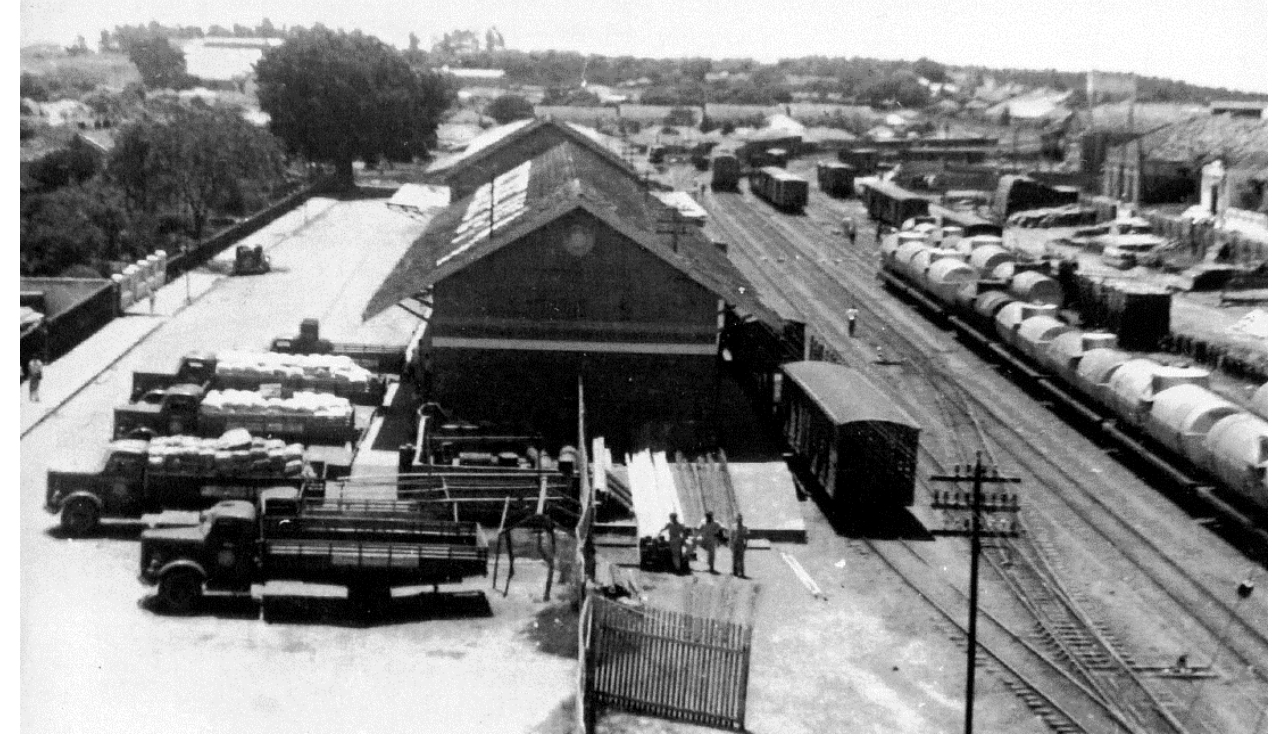

Fonte: Museu e Arquivo Histórico Antônio Sandoval Netto.

Até mesmo a água para consumo da população, cujo abastecimento foi inaugurado apenas em 1938 (FAGUNDES, 2018) - e apenas na região central e para quem pudesse pagar por sua instalação -, era proveniente de quatro poços que se localizavam a leste da ferrovia (ABREU, 1972) e armazenada na caixa de água da Vila Marcondes, localizada na praça da Igreja Nossa Senhora Aparecida.

Segundo o Plano Diretor de Presidente Prudente (1969), apenas em 1958 é que viria a ser implantado o abastecimento de água com captação no Ribeirão Mandaguari - localizado também a leste da Vila Marcondes -, que é um afluente do Rio do Peixe - do qual a cidade capta atualmente a maior parte de suas águas para abastecimento, como relatado no capítulo anterior.

Assim, observa-se que, apesar da expansão mais significativa da malha urbana ter se dado a oeste, sobre a sub-bacia do Córrego do Veado, dentro da atual Unidade de Gerenciamento do Pontal do Paranapanema, a captação das águas para o consumo sempre ocorreu a leste do espigão, na bacia e sub-bacias da Unidade do Rio do Peixe. Para a sub-bacia do Córrego do Veado sempre foram direcionadas as águas servidas.

Em relação aos espaços livres qualificados (figura 49) para o lazer e desfrute da população, a planta da cidade de 1939 (apresentada no capítulo anterior) evidencia a presença de um pequeno sistema - composto por três praças - conectando as duas 
Vilas à estação ferroviária; e também um espaço com traçado orgânico identificado como Bosque Municipal.

Figura 49 - Espaços livres qualificados na década de 1940.

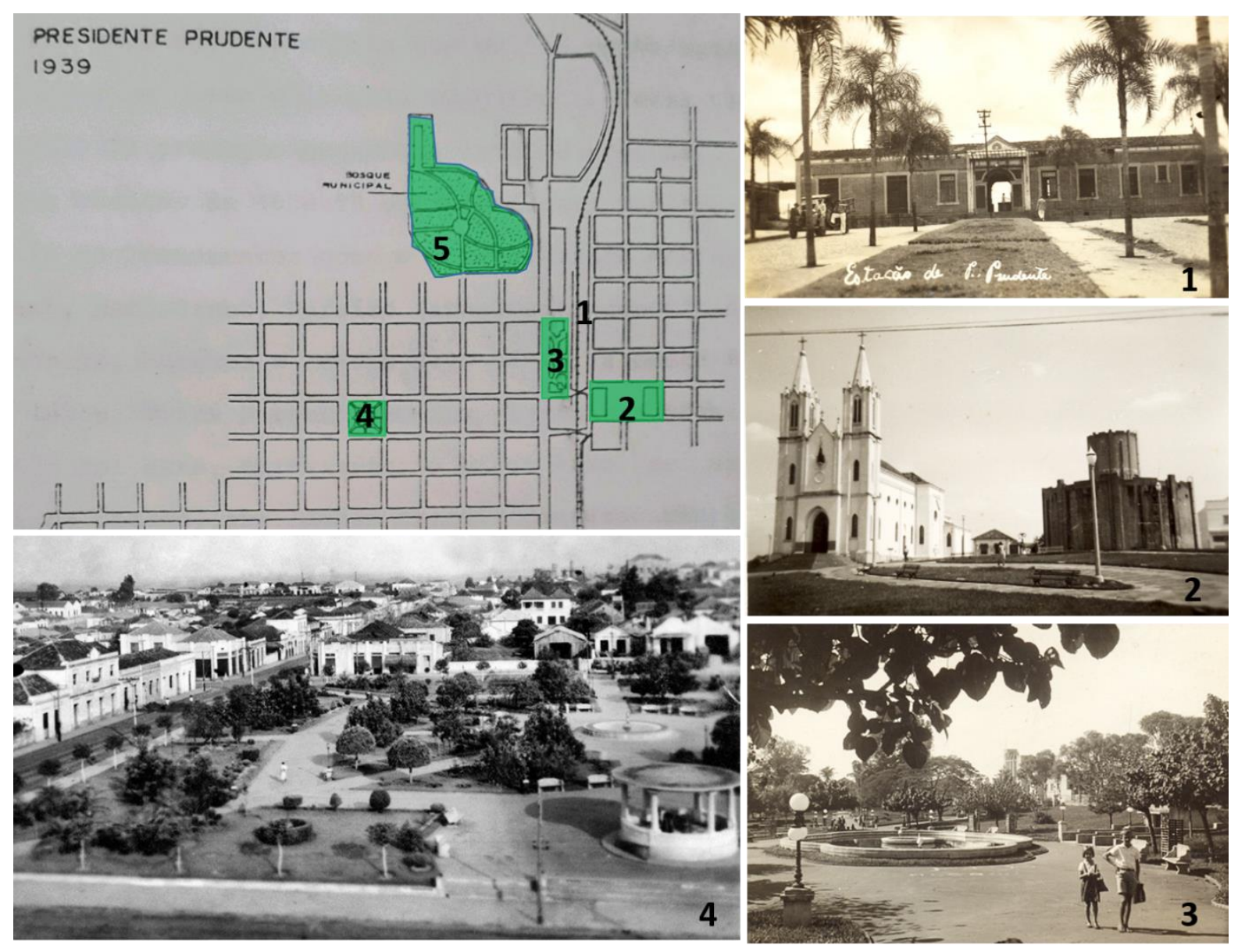

À esquerda (acima): Presidente Prudente, 1939. Representação elaborada pela Companhia Elétrica Caiuá. Fonte: Sposito (1983). Fotografia 1: Estação Ferroviária, 1930 (o edifício atual seria inaugurado em 1944 e está ao fundo da praça na fotografia 3) Fotografia 2: Igreja Nossa Senhora Aparecida e Caixa d'água, década de 1940. Fotografia 3: Praça da Bandeira, década de 1940. Fotografia 4: Praça 09 de Julho, década de 1930. Fonte das fotografias: Museu e Arquivo Histórico Antônio Sandoval Netto.

Com relação ao Bosque Municipal, este representava uma das poucas reservas florestais (figura 50) próximas à área urbana e, segundo Abreu (1972), sua área pertencia ao Coronel Goulart e, em 1938, foi arrendada à prefeitura por cinco anos, sendo o Bosque Municipal entregue, como espaço de lazer à população, em 1940 (KUNZLI, 1997 apud FAGUNDES, 2018). Porém, o contrato de arrendamento não seria renovado e, em 1943, o Bosque voltaria à família Goulart, que venderia suas terras nos anos seguintes, dando origem ao loteamento conhecido como bairro Bosque. 
Figura 50 - Aerofoto Oblíqua de Presidente Prudente 1939/1940.

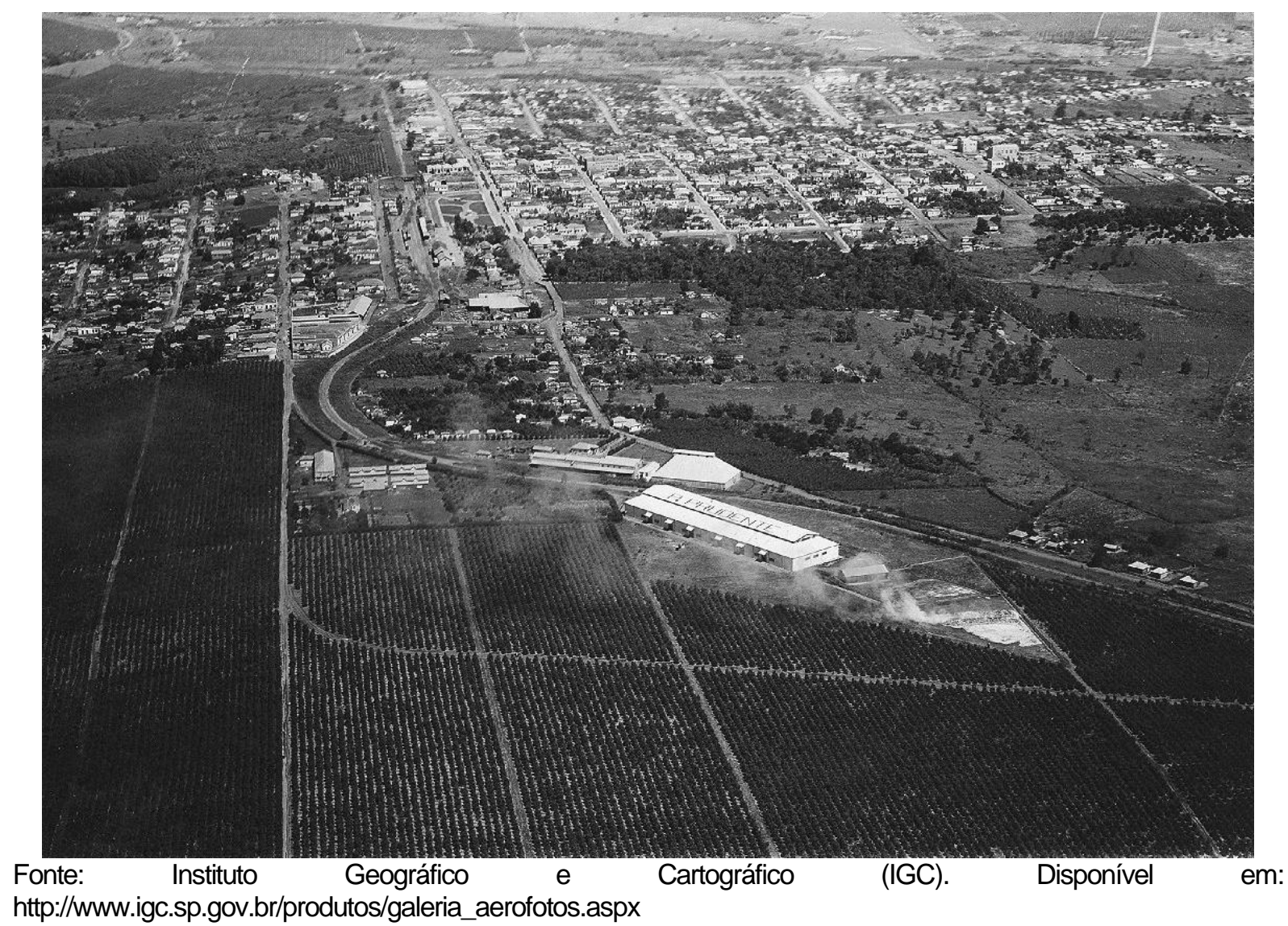

Segundo Museu e Arquivo Histórico Antônio Sandoval Netto, o Bosque Municipal possuía playground, ruas com bancos e iluminação, caminhos para 0 passeio e desfrute da população. Além disso, era um dos poucos espaços sombreados da cidade (figura 51) e, de acordo com mapas antigos, as nascentes originais do Córrego Bacarin localizavam-se dentro de sua área.

$\mathrm{Na}$ fotografia acima, já é possível observar um maior desenvolvimento da malha urbana a oeste (a fotografia foi tirada no sentido Sul), assim como o início da ocupação das regiões de fundo de vale dos Córregos Água Bôscoli (canto superior direito da imagem) e, a partir do Bosque, do Córrego Bacarin. 
Figura 51 - Bosque Municipal, década de 1940.
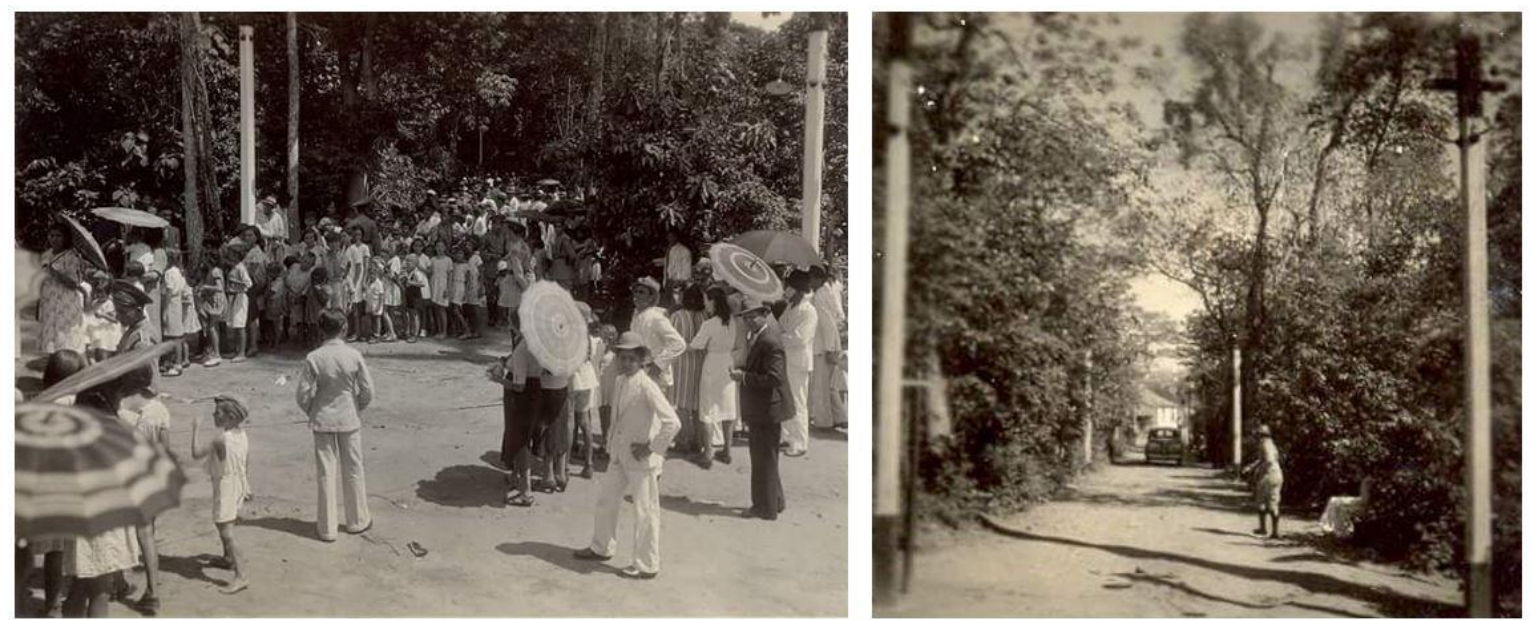

Fonte: Museu e Arquivo Histórico Antonio Sandoval Netto.

Se no ano de 1940 a população urbana de Presidente Prudente era de 12.637 habitantes (SPOSITO, 1983), o censo para o ano de 1950 revelaria que a população urbana mais que dobraria em dez anos, chegando a 28.793 habitantes.

A industrialização aumentara, com a vinda de indústrias de processamento de carne e derivados (frigoríficos e curtumes), que se instalariam, principalmente, próximas ao córrego do Veado; além disso, a abertura e pavimentação de rodovias traria impactos sobre a forma urbana.

Se a leste da ferrovia o crescimento era, em partes, limitado pelo relevo de característica mais abrupta, a oeste o crescimento se dava principalmente na direção do Córrego do Veado, percorrendo a região de fundo de vale do Córrego Água Bôscoli e as vias principais da cidade (figura 52). Estas, que eram as avenidas que definiam o chamado quadrilátero central, haviam adquirido especificidades de uso e ocupação: a Avenida Brasil, primeira porta de entrada da cidade, paralela à ferrovia, e a Avenida Manoel Goulart, que viria a se conectar com a rodovia Raposo Tavares, se especializariam em usos comerciais e de prestação de serviços; a Avenida Washington Luiz, que se inicia na esplanada da estação ferroviária e percorria o trecho mais próximo ao Bosque Municipal, fechando o quadrilátero juntamente com a Avenida Coronel José Soares Marcondes, viriam a desenvolver usos mais residenciais - nesta última avenida principalmente a norte e nordeste - e representariam o principal eixo de expansão imobiliária da elite nos anos de 1960. 
Figura 52 - Planta de Presidente Prudente, 1947, com modificações feitas pelo autor. A imagem apresenta a indicação das nascentes dos córregos Bacarin e Água Bôscoli.

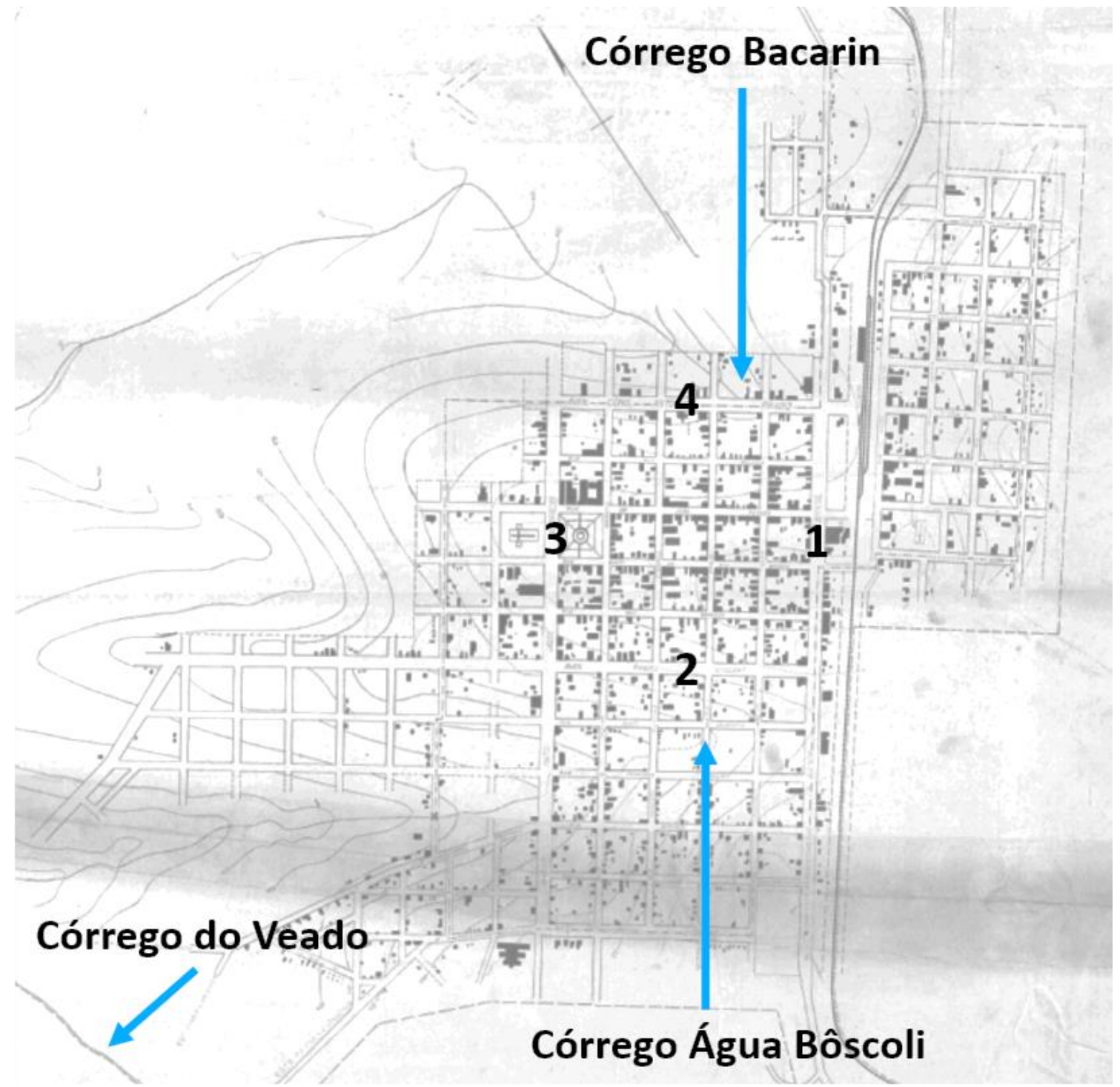

Os números representam, respectivamente, as avenidas que formam o quadrilátero central: 1- Brasil; 2- Manoel Goulart; 3- Coronel José Soares Marcondes; 4- Washington Luiz. Fonte: Arquivo Público do Estado de São Paulo.

O detalhe da Planta de Presidente Prudente de 1947 (figura 53), já mostra a nascente e alguns metros do Córrego Água Bôscoli ${ }^{49}$ aterrados e transformados em galeria.

49 Segundo Fagundes (2018), o nome do córrego está ligado à família que possuía uma serralheria próxima ao antigo "buracão" - que se iniciava onde atualmente está localizado o PUM (Parque de Uso Múltiplo). 
Figura 53 - Detalhe ampliado da Planta de Presidente Prudente, 1947, com demarcação da região inicial do Córrego Água Bôscoli, já transformado em galeria.

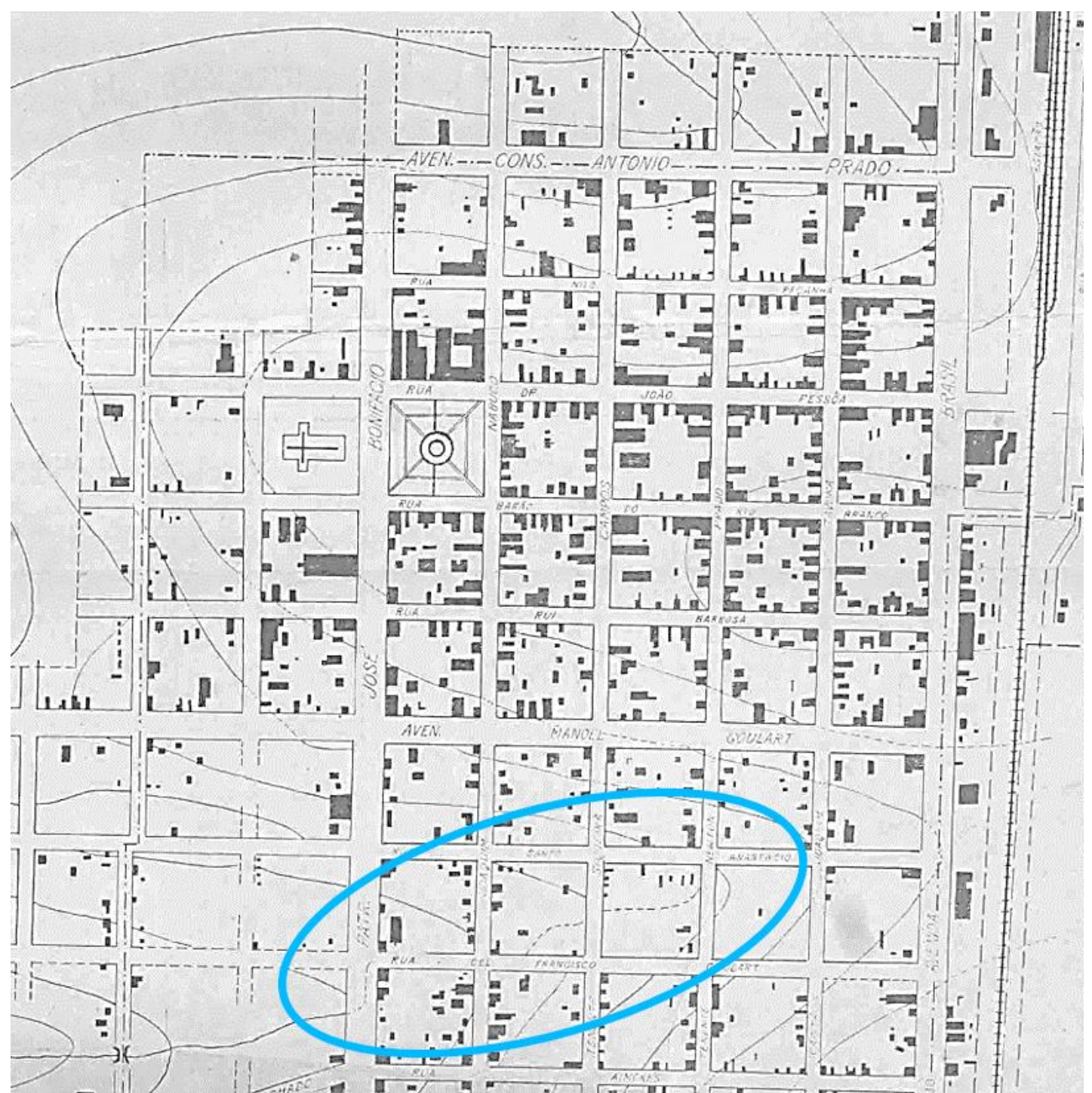

Fonte: Arquivo Público do Estado de São Paulo

Com relação ao Córrego Bacarin, a região do Bosque viria a ser loteada. Esse processo causou alterações na hidrologia do território comprometendo a nascente do córrego e resultando nas esperadas as erosões de seu fundo de vale, que viria a ser nominado como Buracão do Bacarin 50 - essa alteração e seu trecho inicial seriam canalizados ainda na década de 1950. Assim, a Lei Municipal no 301, de 25 de maio de 1954, apresentaria em seus artigos:

Artigo $1^{\circ}$ - Fica declarada de utilidade pública para posterior desapropriação por via amigável ou judicial, uma faixa de terras medindo 13 (treze) metros de largura por 1.315 (hum mil, trezentos e

50 Segundo Sposito (1983), Bacarin era o nome de uma família que mantinha um comércio - armazém - próximo ao curso d'água e seu "buracão", dando origem assim ao nome pelo qual ficaria reconhecido também o córrego. 
quinze) metros de comprimento, num total aproximada de 17.000 (dezessete mil) metros quadrados, situada entre as ruas São Sebastião e Vitória ${ }^{51}$, desta cidade, pertencente a quem de direito.

Artigo $2^{\circ}$ - A área de terras objeto da presente declaração, uma vez adquirida pela Prefeitura Municipal, servirá para construção de um canal, conforme planta anexa ${ }^{52}$, afim de evitar a erosão existente naquele trecho. (PRESIDENTE PRUDENTE, 1954)

Como pode ser observado pelas descrições e imagens apresentadas, a canalização dos córregos era uma diretriz estruturante do planejamento e desenvolvimento municipais, já observada desde a década de 1940, quando se deu o crescimento urbano sobre os primeiros fundos de vale e cursos d'água.

Por mais que os mapas evidenciem a presença de córregos e nascentes próximas ao centro, o texto da Lei Municipal n³01/1954 deixa claro o tratamento dado ao córrego, ao relatar a desapropriação de terras para a construção de um canal que, conforme testemunham as fotografias (figura 54, por exemplo), no mais das vezes significava a canalização em galerias.

Figura 54 - Bacarin: aterro do "buracão" e canalização do córrego, localizados em frente à "Casa Bacarin", sem data.

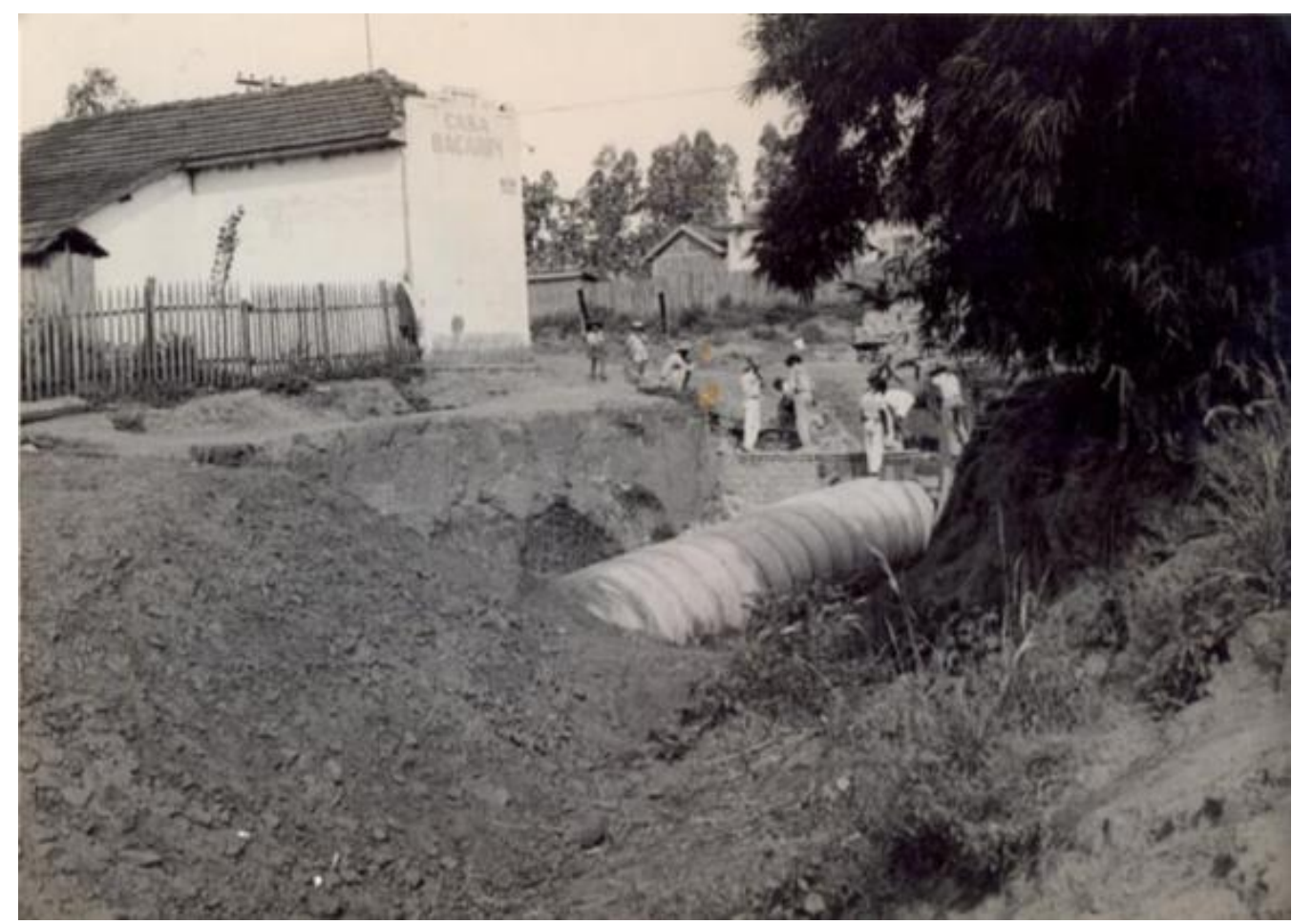

Fonte: Museu e Arquivo Histórico Antonio Sandoval Netto.

${ }^{51}$ Atual Rua Emilio Mori. Disponível em "Consulta Bairros e Logradouros" no site da Prefeitura Municipal de Presidente Prudente.

$52 \mathrm{O}$ arquivo anexo citado não consta na pesquisa desta Lei, realizada virtualmente. 


\subsubsection{Décadas de 1960 e 1970}

Conforme destaca Sposito (1983), o crescimento da população urbana de Presidente Prudente registrou, desde seu início, crescimentos proporcionais mais expressivos que a Alta Sorocabana, o Estado de São Paulo e o Brasil. Em números aproximados, no ano de 1960, a população urbana de Presidente Prudente era de 54 mil habitantes; no censo de 1970, eram 91 mil habitantes; em 1980, 128 mil habitantes. Já no início da década de 1970, a população urbana de Presidente Prudente correspondia a $41,5 \%$ de toda a população urbana dos municípios da Alta Sorocabana (SPOSITO, 1983).

A partir dos mapas produzidos pelo CPEU para Presidente Prudente na década de 1960 e do mapa produzido pelo IBGE na década de 1970, apresentados no capítulo III, e somado o trabalho desenvolvido por Sposito (1983), reafirma-se que durante estas décadas a expansão urbana de Presidente Prudente desenvolveu-se sobre os espaços compreendidos entre a linha férrea e a margem direita do Córrego do Veado, ocupando os fundos de vale e margens dos Córregos Água Bôscoli, Bacarin e um afluente do Córrego Colônia Mineira - conhecido como "buracão da Raposo" ou "buracão Duque de Caxias", na Vila Geni - ao norte da avenida Washington Luiz.

A partir das décadas de 1950 e 1960, quando entram em pauta os planos de descentralização industrial e criação de polos regionais de desenvolvimento, Presidente Prudente ganha destaque como capital do oeste paulista e é escolhida para sediar um projeto modelo de Distrito Industrial, visando à melhoria e dinamização da economia local e regional, fixação da população, bem como descentralização da indústria - concentrada no eixo Rio de Janeiro - São Paulo -, aproveitando-se da mão de obra proveniente do campo e do mercado consumidor crescente nas cidades.

O Projeto para o Distrito Industrial, elaborado pelo CPEU a pedido da CIBPU, representou um dos primeiros contatos do poder público municipal com um plano de crescimento e expansão. Para a implantação do distrito, porém, fazia-se necessário o desenvolvimento de um Plano Diretor de Desenvolvimento Integrado para o município, que também foi desenvolvido pelo CPEU, em conjunto com a Prefeitura Municipal e a Associação dos Arquitetos e Engenheiros da Alta Sorocabana e que também visava ao atendimento da nova Lei Orgânica dos Municípios, em 1967, que atrelava a provisão de recursos e financiamentos à obrigatoriedade de um plano diretor municipal. 
Assim, como relatado no capítulo III, seguindo as diretrizes do Plano Diretor e do Projeto para o Distrito Industrial - que projetavam duas avenidas sobre o fundo de vale do Córrego do Veado, interligando as duas principais áreas industriais, e em seu centro um espaço multiuso de esportes, além da preservação paisagística do fundo de vale - a prefeitura lançaria o projeto "Fundo de Vale" em 1976, que serviria à construção do Parque do Povo e, entre 1977 e 1982, a partir de recursos do BNH, lançaria os Projetos CURA, contendo em suas diretrizes principalmente as obras de drenagem - canalização de córregos e construção de galerias pluviais.

Este momento representou o início dos projetos de canalização em grande escala e transformação das águas urbanas fluviais em galerias, replicando projetos da engenharia cinza aplicados na metrópole adaptando-os às cidades do interior. Com as novas legislações e o aporte de recursos dos governos federal e estadual, entra em curso o processo de "saneamento" da cidade e "urbanização dos fundos de vale", envolvendo desde a construção de galerias pluviais e o asfaltamento de diversas ruas, até mesmo construção de redes de água e esgoto e canalização de córregos, que representavam soluções às questões de mau-cheiro, poluição, sujeira, acúmulo de lixo e de doenças propagadas por vetores ligados às águas.

A canalização dos Córregos Água Bôscoli, Bacarin e Veado realizados nesse período, traria profundas transformações na produção do espaço urbano de Presidente Prudente e em sua expansão urbana, que a partir dos anos 1970 “caracterizou-se por ser empresarial” (SPOSITO, 1983, p. 192), com a abertura e a vinda de empresas incorporadoras. Ainda segundo Sposito (1983):

A progressiva valorização de algumas áreas da cidade impetrada sobretudo pela alocação de benfeitorias, serviços públicos e de todas as externalidades advindas desta alocação, promoveu na década de 70 um destacável processo de afastamento espacial dos extratos sociais de rende mais baixa. Este processo verificou-se no Jardim Paulista, tanto quanto naqueles loteamentos adjacentes ao Parque do Povo e ocupados antes da implantação do projeto. (SPOSITO, 1983, p 217)

Se até os anos de 1960 o loteamento Jardim Bongiovani (figura 55), que desde seu lançamento (1962) mantinha um alto preço com foco na elite (SPOSITO, 1983) não havia emplacado em vendas por estar distante das áreas centrais e da melhor infraestrutura urbana, a partir das obras realizadas na década de 1970, o entorno do Córrego do Veado passaria por uma transformação, tornando-se uma nova centralidade nos anos seguintes e, com isso, o Jardim Bongiovani se tornaria o eixo 
de expansão da elite e as obras no fundo de vale permitiriam uma grande expansão da malha urbana, transpondo o Córrego que era, até então, encarado como uma grande barreira.

Figura 55 - Vista aérea (ao fundo) do loteamento Jardim Bongiovani, ainda desocupado. O Córrego do Veado com entorno livre, em partes, e em momento anterior às obras do Projeto Fundo de Vale, que originariam o Parque do Povo.

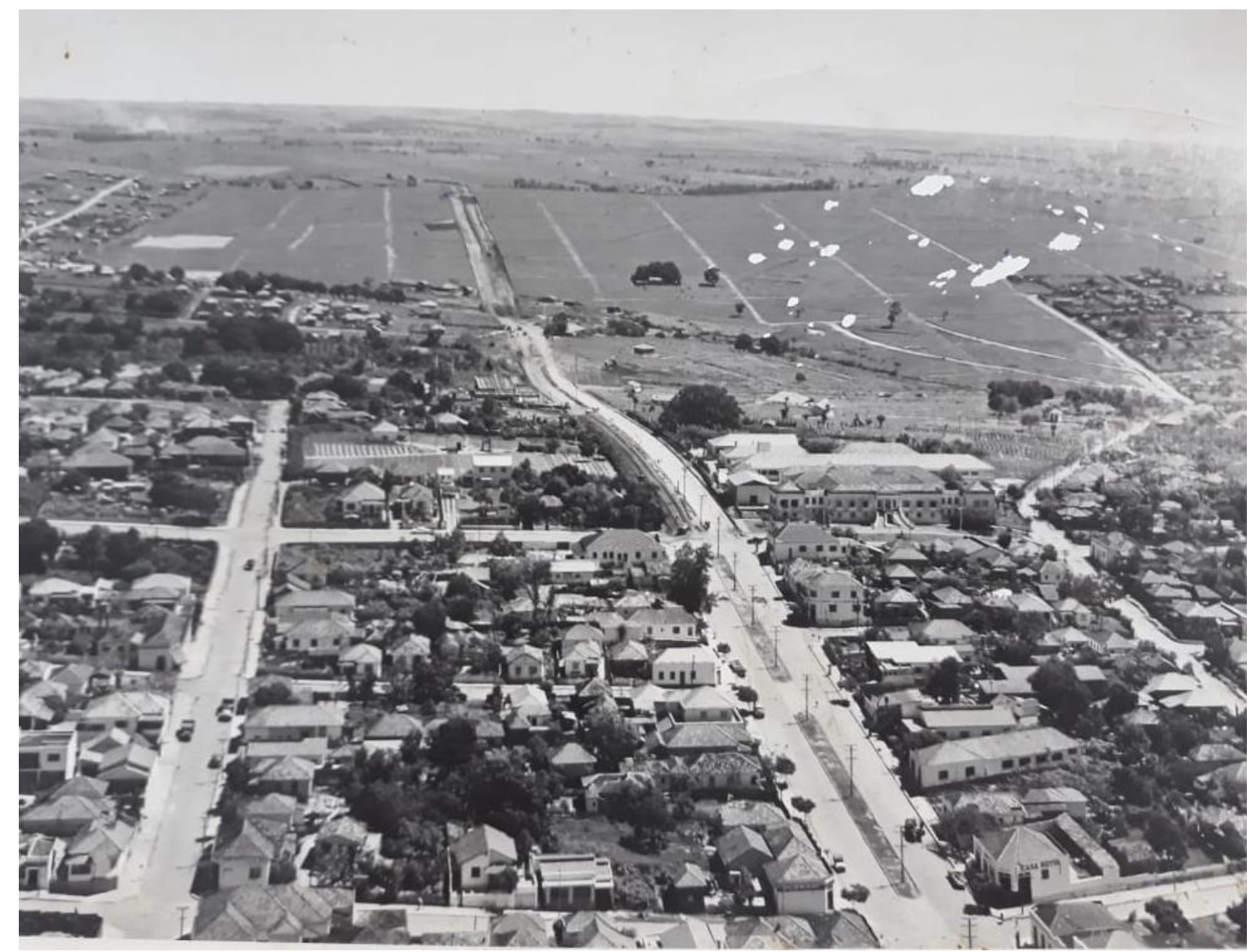

Fonte: arquivo pessoal de Marly Bongiovanni Martins.

As relações rio e cidade neste intervalo de tempo serão apresentadas para cada córrego através de uma série comparativa de imagens entre fotos aéreas e mapas da década de 1970 e imagens de satélite obtidas com o Google Earth em 2019.

\section{Córrego Água Bôscoli}


Figura 56 - Região do Córrego Água Bôscoli.

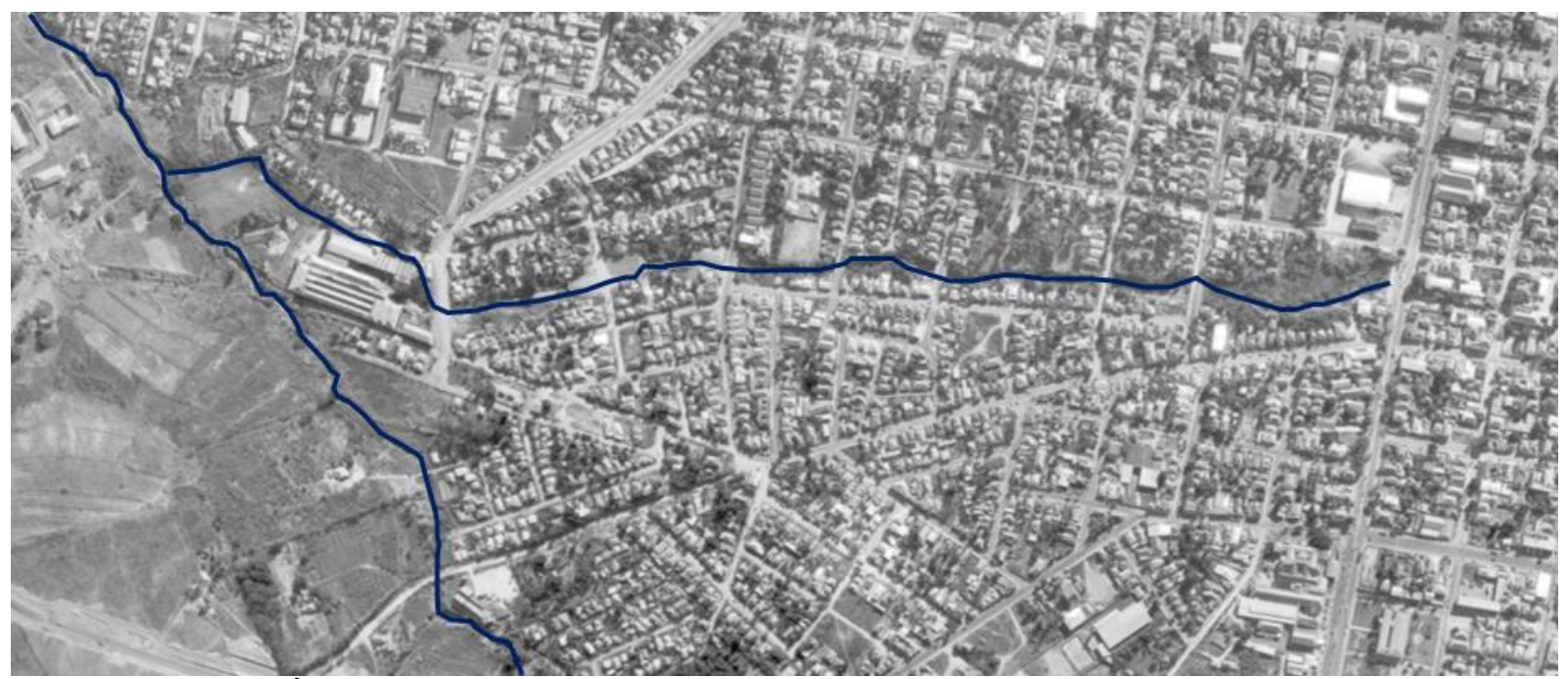

Região do Córrego Água Bôscoli, meados da década de 1970. Fonte: recorte de fotografia aérea produzida pela empresa TerraFoto S.A. para a Prefeitura Municipal de Presidente Prudente, modificada pelo autor.

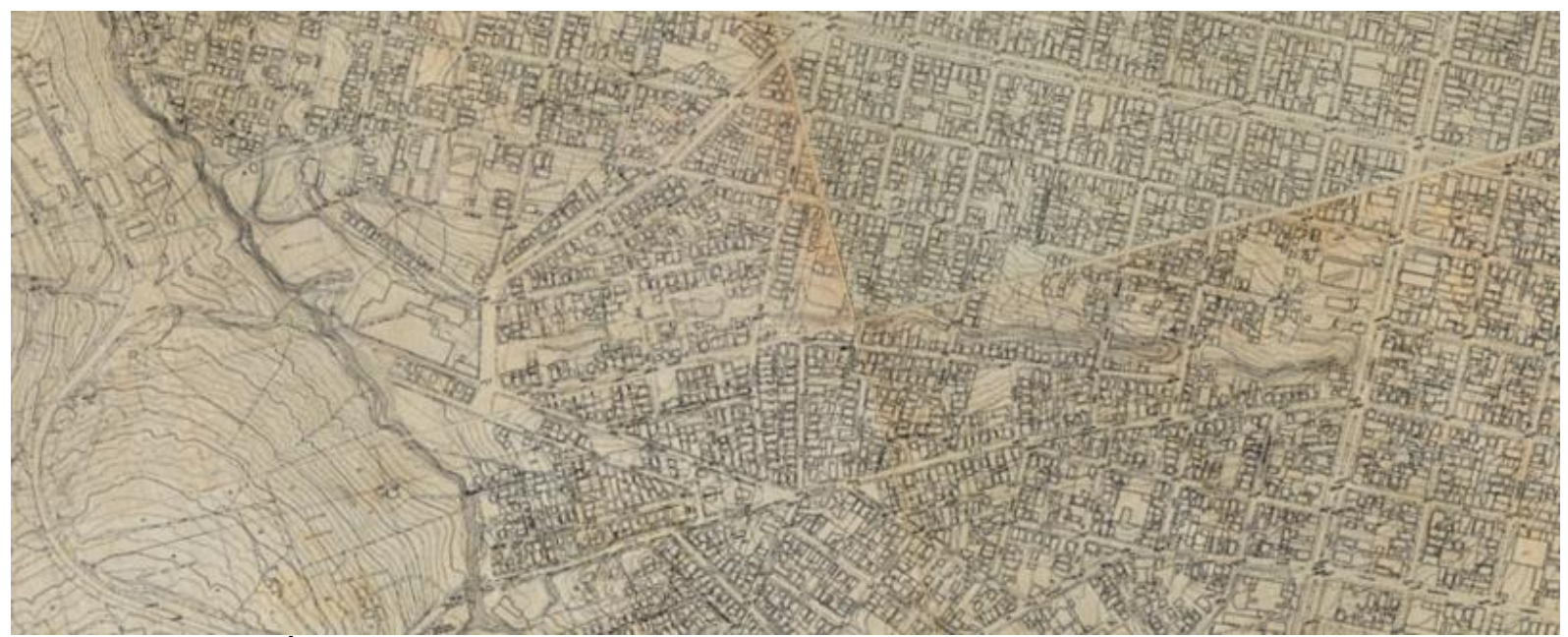

Região do Córrego Água Bôscoli, 1977, em mapas produzidos pela empresa TerraFoto S.A. para o Departamento de Água e Esgoto (DAE) de Presidente Prudente. Fonte: Prefeitura Municipal de Presidente Prudente.

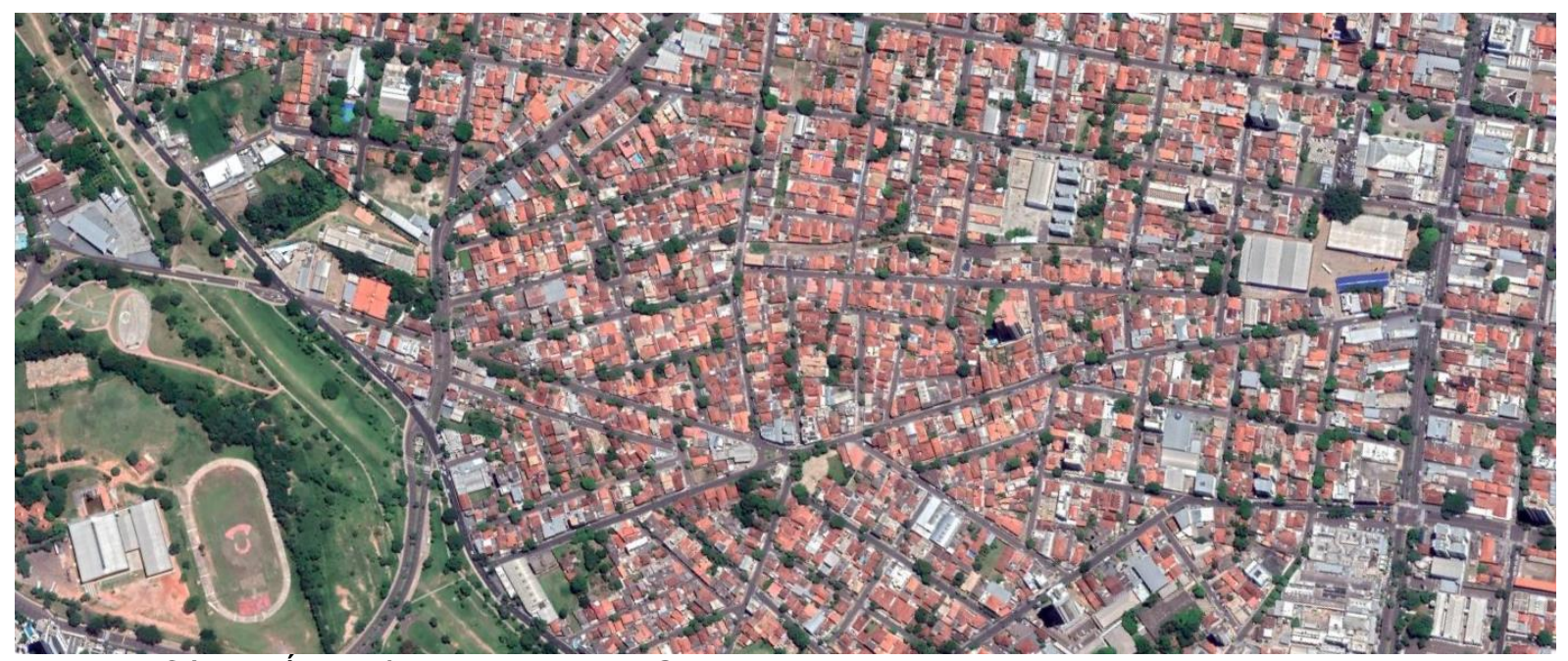

Região do Córrego Água Bôscoli, 2019. Fonte: Google Earth. 
As imagens acima (figura 56) representam a ocupação no fundo de vale do Córrego Água Bôscoli, antes de sua canalização, realizada com verbas do Projeto CURA. As imagens a seguir mostram o processo de transformação do córrego em galeria (figura 57), canalizado e tamponado. Sobre ele, às margens da avenida Coronel José Soares Marcondes, é construído o PUM - Parque de Uso Múltiplo (figura 58) e uma rua de pedestres (figura 59). O único trecho do córrego que continua aberto está localizado próximo à sua foz - ao lado da TV Fronteira, sede regional da Rede Globo - antes de desaguar no Córrego do Veado, embaixo do Parque do Povo.

Figura 57 -Obras de canalização do Córrego Água Bôscoli, década de 1970. O local da foto corresponde à área ocupada atualmente pelo PUM.

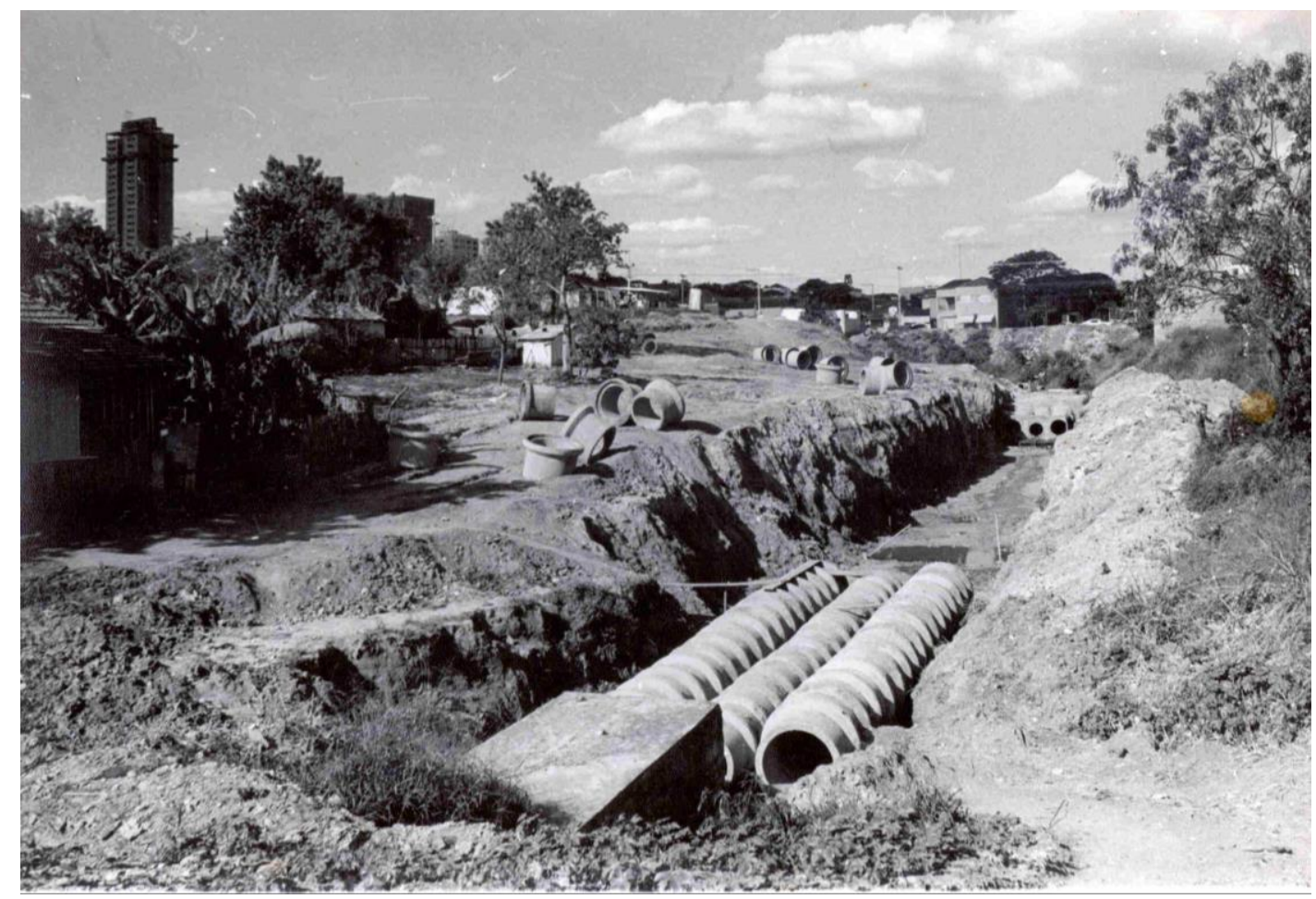

Fonte: Museu e Arquivo Histórico Antonio Sandoval Netto.

As relações rio - cidade neste período são evidenciadas pela construção de um espaço de lazer e esportes sobre a nascente do córrego, com o encaixamento de sua nascente e a transformação de parte do leito em uma rua de pedestres. Porém, a relação de negação com o curso de água e para com o fundo de vale é intensificada ao se aprovar a Lei no 2047 de 1979 que, em seu artigo primeiro, proíbe a construção de edifícios com frente para a rua de pedestres sobre a "galeria do Boscoli" e ainda, no artigo segundo, proíbe qualquer acesso das propriedades lindeiras, em outras palavras, a Lei impede contato direto entre a edificação e a rua de pedestres. 
Figura 58 - Antigo "Buracão do Bôscoli", onde está localizado o Córrego Água Bôscoli e sobre o qual foi construído o Parque de Uso Múltiplo (PUM), com recursos do programa CURA.

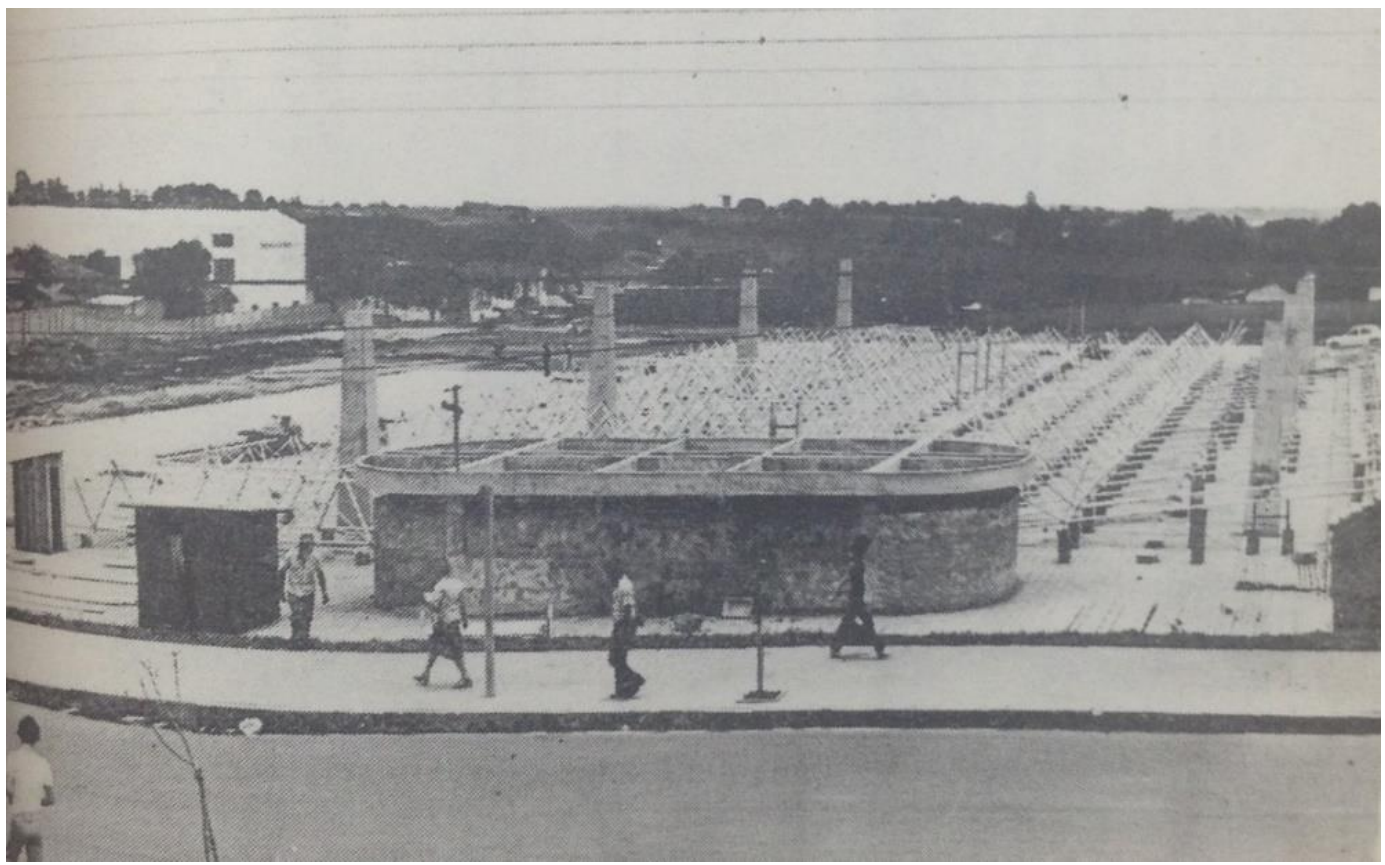

Fonte: Relatório "Presidente Prudente: capital regional", disponível na biblioteca da FCT-UNESP.

Figura 59 - Rua de Pedestres sobre o córrego Água Bôscoli, neste registro, canalizado e tamponado.

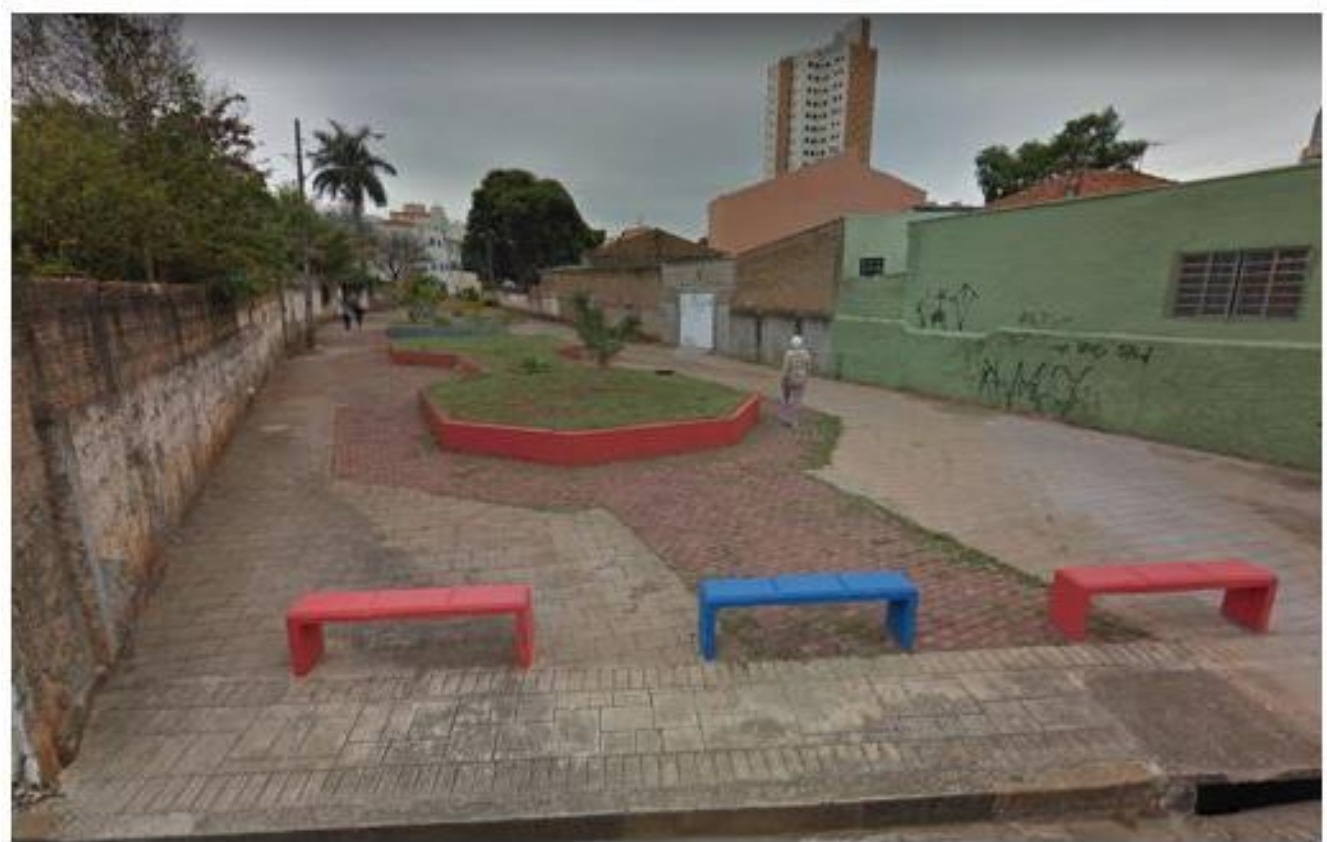

Fonte: Google Street View (2017).

\section{Córrego Bacarin}


O Córrego Bacarin (figura 60) teve seu trecho inicial canalizado ainda nos anos de 1950, porém foi nas décadas de 1970 e 1980 que se consolidou o processo de tamponamento do córrego e expansão urbana sobre sua galeria e fundo de vale.

Figura 60 - Região do Córrego Bacarin

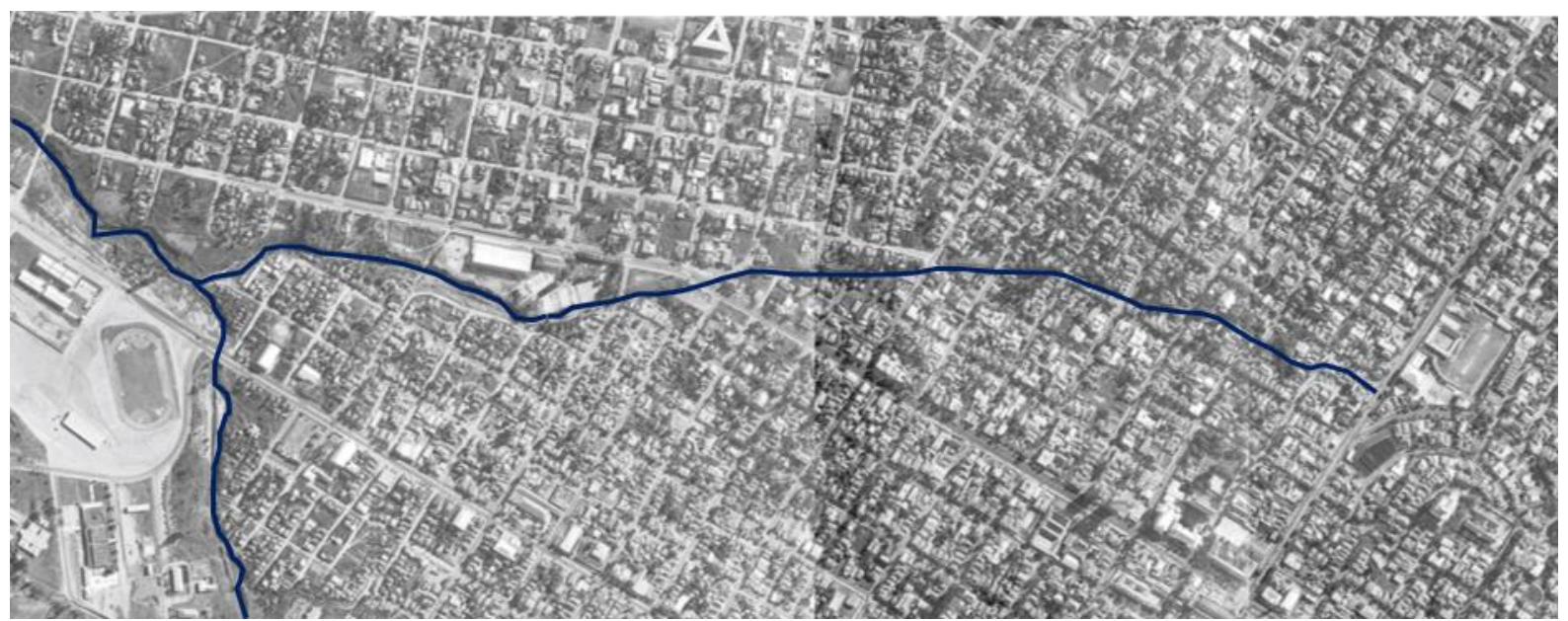

Região do Córrego Bacarin, meados da década de 1970. Fonte: recorte de fotografia aérea produzida pela empresa TerraFoto S.A. para a Prefeitura Municipal de Presidente Prudente, modificada pelo autor.

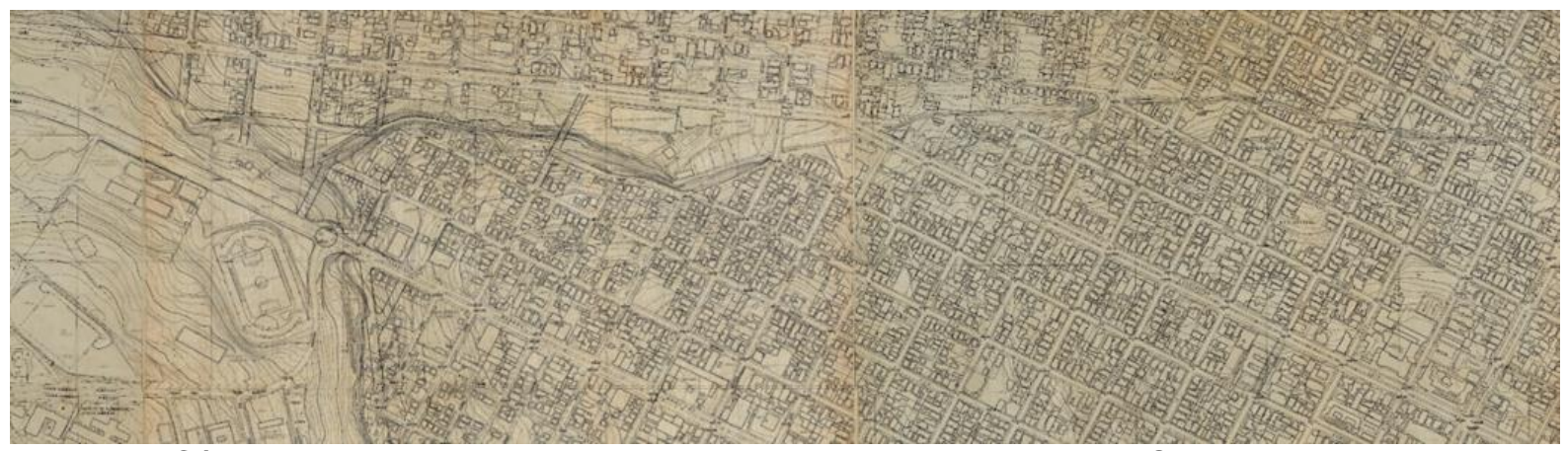

Região do Córrego Bacarin, 1977, em mapas produzidos pela empresa TerraFoto S.A. para o Departamento de Água e Esgoto (DAE) de Presidente Prudente. Fonte: Prefeitura Municipal de Presidente Prudente.

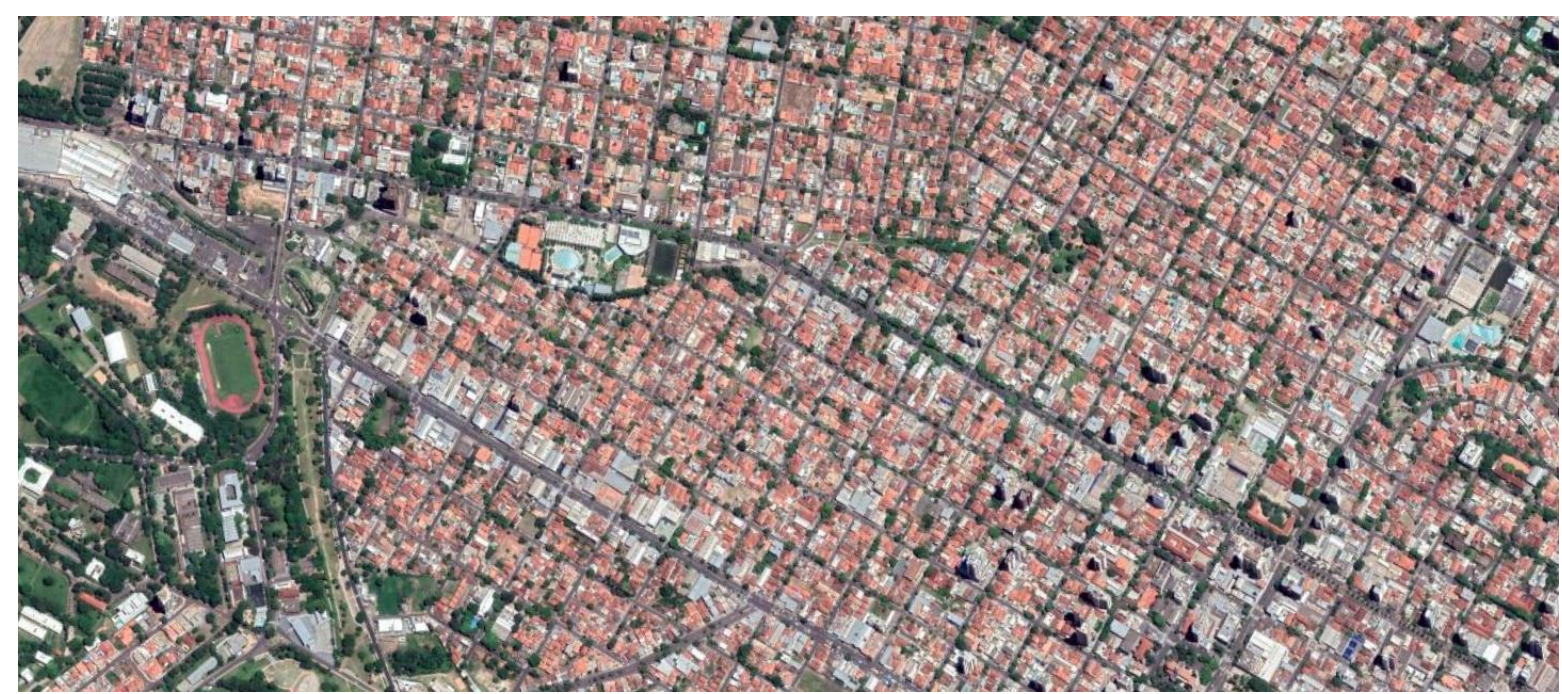

Região do Córrego Bacarin, 2019, completamente invisível na paisagem cotidiana. Fonte: Google Earth, 2019. 
O encontro das águas do Bacarin com as do Córrego do Veado se dá ao término do Parque do Povo, embaixo da área do atual estacionamento do Prudenshopping - shopping este que também foi construído no final da década de 1980 e inaugurado em 1990 - sobre o fundo de vale e trechos dos córregos. O Tênis Clube de Presidente Prudente, clube frequentado pela elite local, tem seus limites fornecidos pela Avenida Washington Luiz, pela frente, e pelo Córrego Bacarin, ao fundo (figuras 61 e 62).

Figura 61- Tênis Clube de Presidente Prudente (sem data), À frente, avenida Washington Luiz e, ao fundo das quadras, o Córrego do Bacarin.

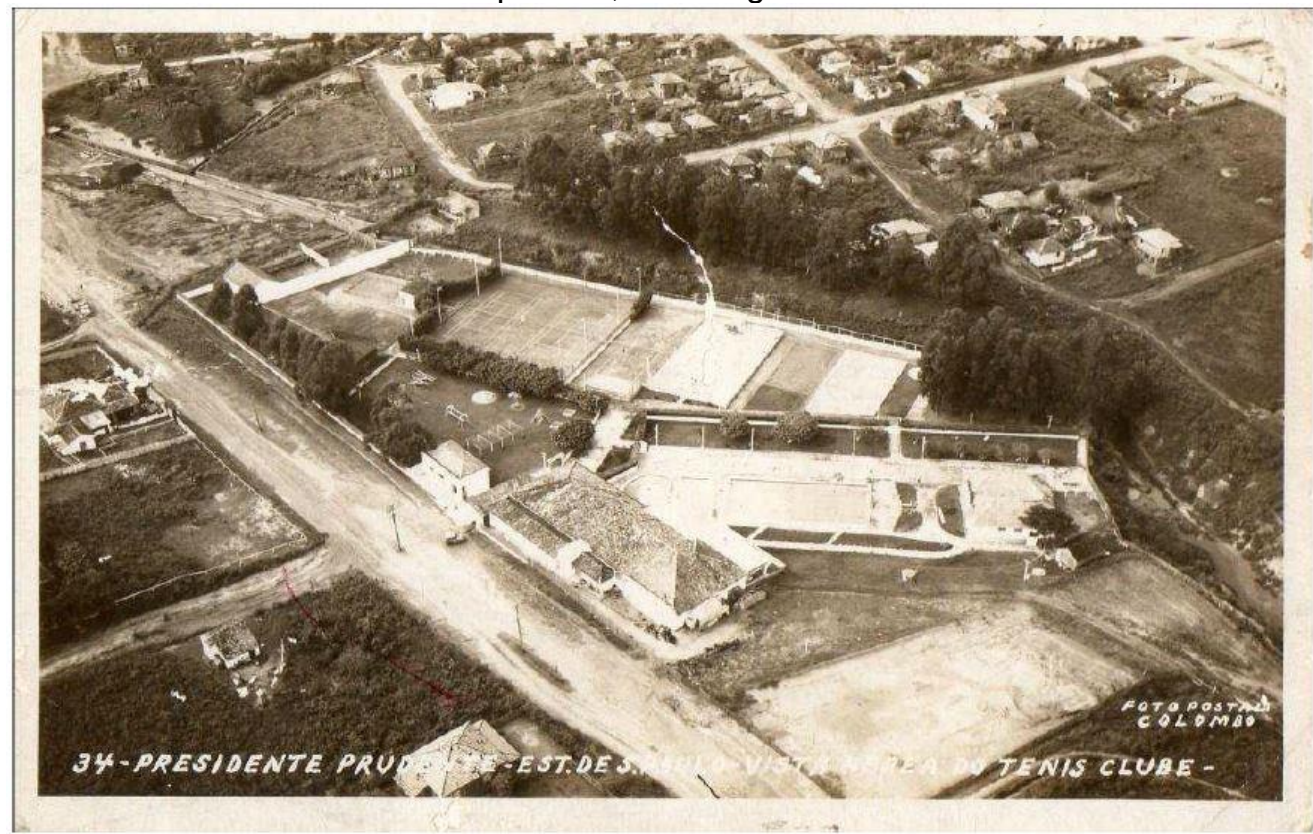

Fonte: Marques (2011).

Figura 62 - Obras de canalização do Córrego Bacarin

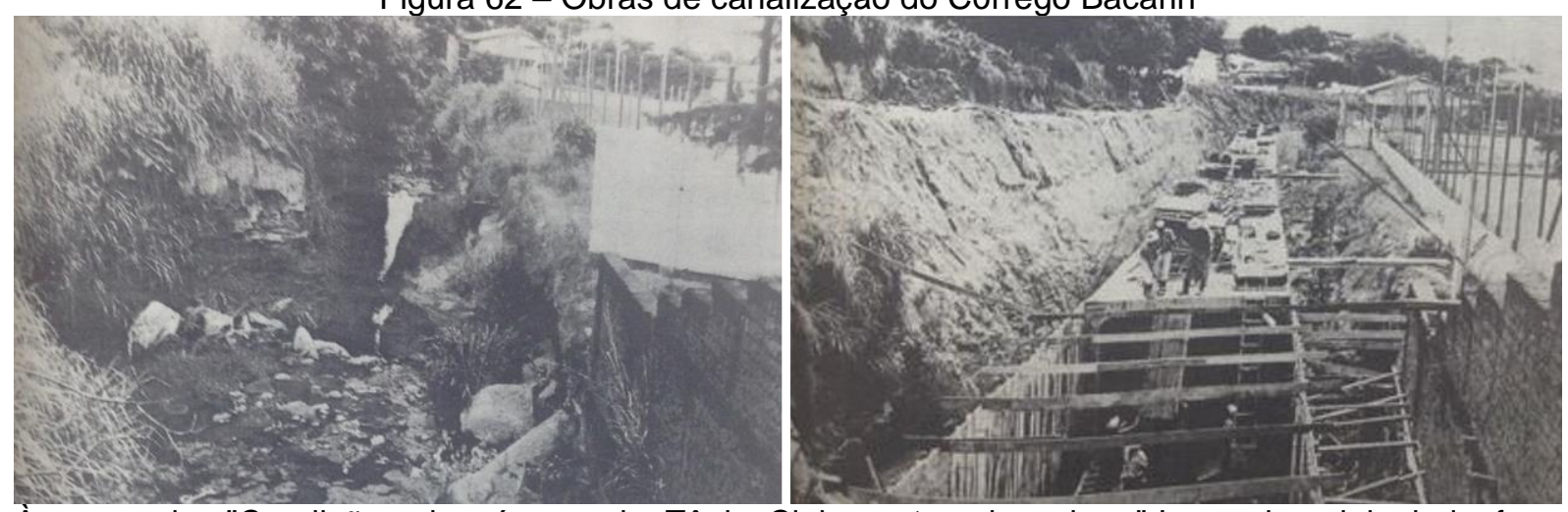

À esquerda, "Condições do córrego do Tênis Clube antes das obras". Legenda original da foto, retratando o córrego Bôscoli, que passa "aos fundos" do Tênis Clube, espaço de lazer e prática esportiva da elite. Fonte: Relatório "Presidente Prudente: capital regional", disponível na biblioteca da FCT-UNESP.À direita, obras de canalização do córrego do Bacarin na região do Tênis Clube de Presidente Prudente. Fonte: Relatório "Presidente Prudente: uma capital regional", disponível na biblioteca da FCT-UNESP de Presidente Prudente. 
Sobre a galeria do córrego, em seu trecho intermediário, no Jardim Aviação, foi construída a Praça do Bacarin (figura 63), e no trecho mais próximo ao Jardim Paulista e ao Tênis Clube, restam espaços livres com áreas permeáveis sobre o córrego canalizado e tamponado (figura 63). Todos os outros trechos restantes do Córrego encontram-se canalizados e sobrepostos por construções ou ruas.

Figura 63 - Espaços livres percorridos no trecho intermediário do Córrego Bacarin, entre o Jardim Aviação e Jardim Paulista.

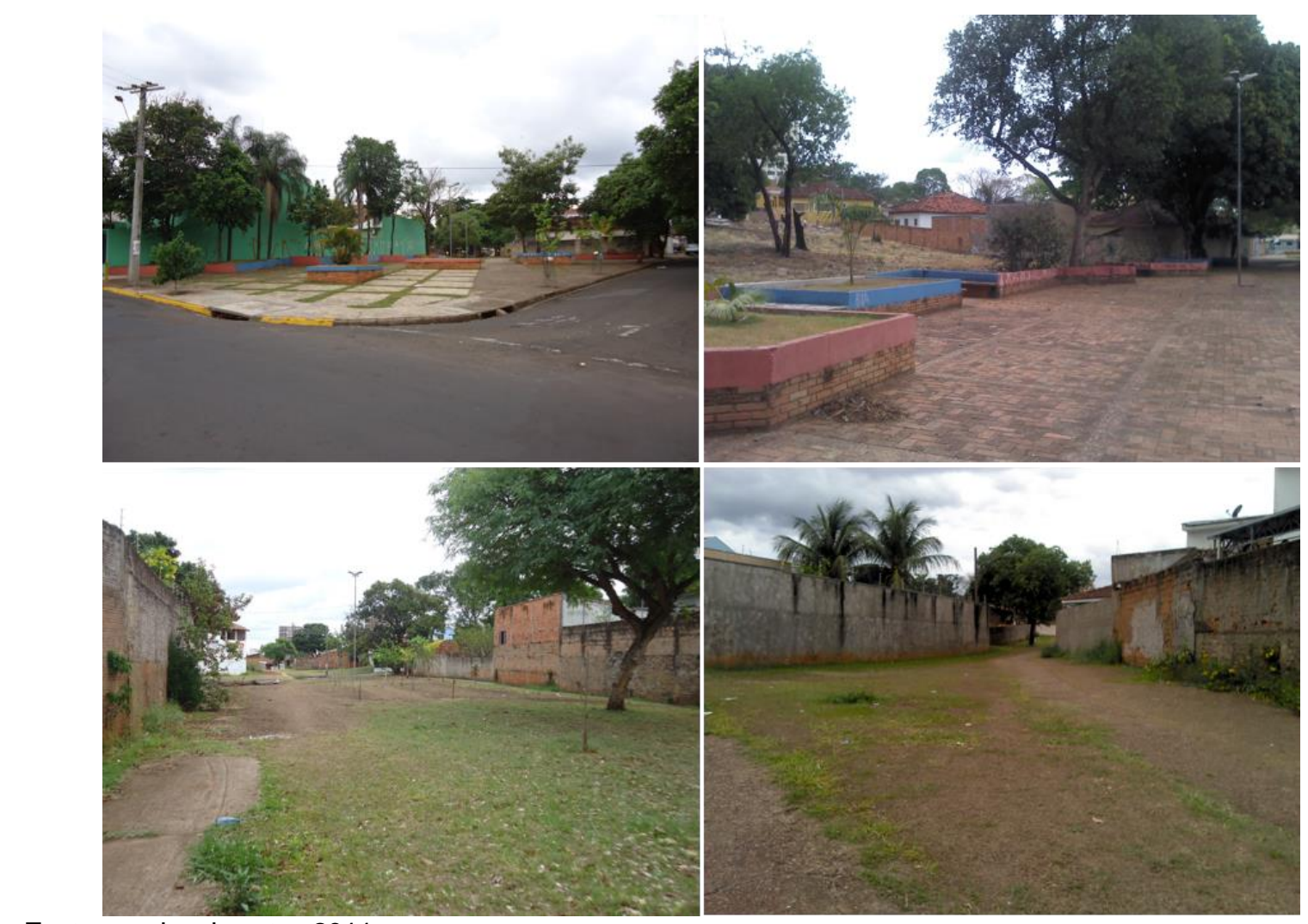

Fonte: arquivo do autor, 2011.

\section{Córrego do Veado}

No Córrego do Veado (figura 64), a prefeitura apresentaria, em 1976, o projeto "Fundo de Vale", que daria origem ao Parque do Povo; ainda que canalizado e retificado - e com avenidas contíguas - o córrego seria considerado em outro registro, pertencente à paisagem e aos olhos da população - com um projeto de canalização aberta, com implantação de vegetação e espaços de lazer, esporte e recreação - a canalização aberta seria substituída pela fechada em meados da década de 1990, justificado frente à população como medida de melhoria devido ao mau cheiro das águas e processos erosivos que levaram ao desmoronamento das placas de concreto em trechos da canalização aberta. 
Embora as regiões de cabeceiras localizadas na área central já estivessem impermeabilizadas nesta época, o Parque do Povo viria a ser uma grande área permeável para toda a Bacia.

Figura 64 - Região do Córrego do Veado.
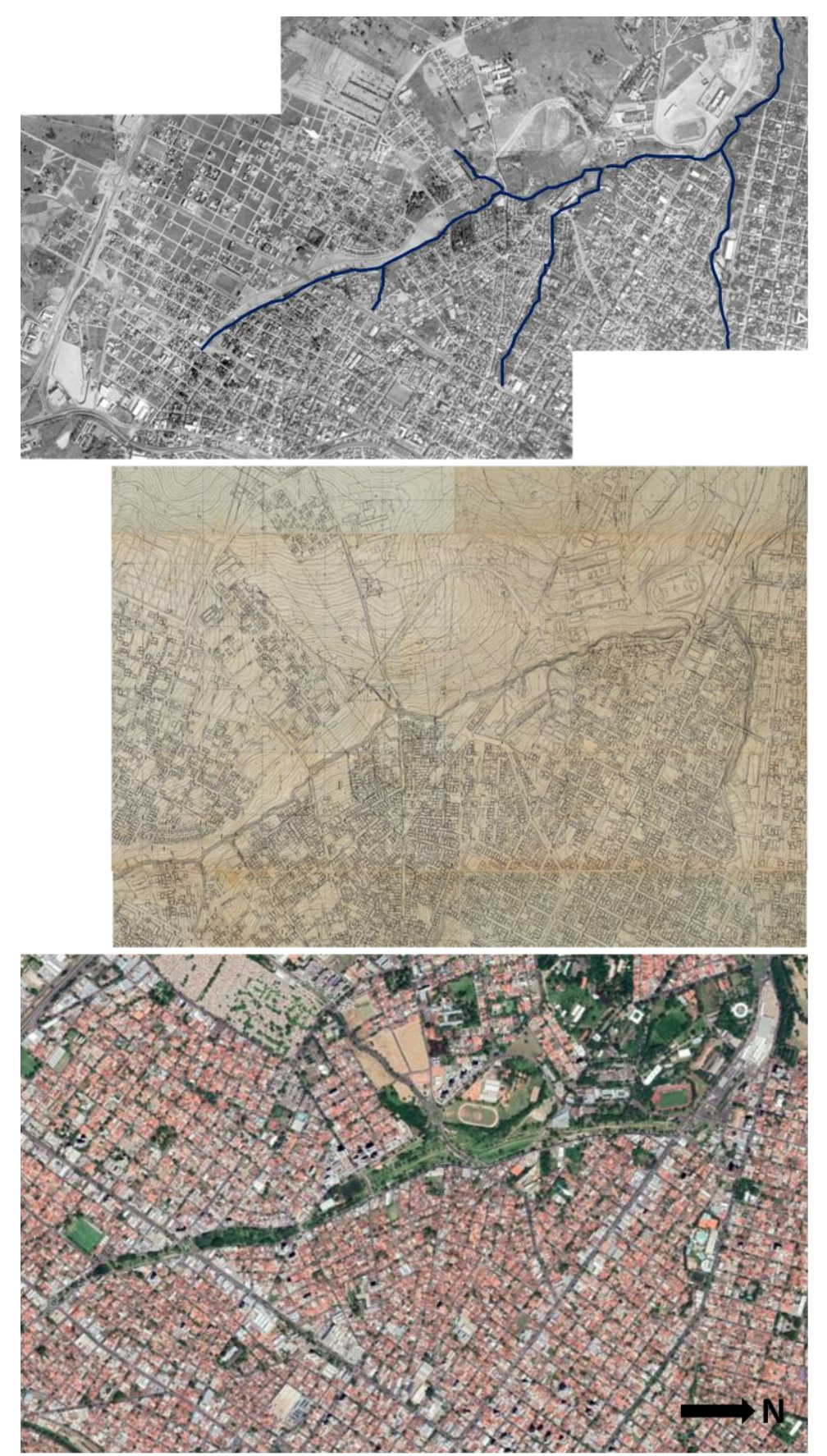

Primeira: Região do Córrego Veado, meados da década de 1970. Fonte: recorte de fotografia aérea produzida pela empresa TerraFoto S.A. para a Prefeitura Municipal de Presidente Prudente, modificada pelo autor.

Segunda: Região do Córrego do Veado, 1977, em mapas produzidos pela empresa TerraFoto S.A. para o Departamento de Água e Esgoto (DAE) de Presidente Prudente. Imagem anterior à construção do Parque do Povo, mas já posterior aos processos de desapropriação para sua realização. Fonte: Prefeitura Municipal de Presidente Prudente.

Terceira: Região do Córrego do Veado, 2019. Fonte: Google Earth. 
Nas imagens dos mapas de 1977, ainda é possível observar o curso natural do córrego, bem como as ocupações que iam até suas margens. Como a cidade havia se desenvolvido até o curso d'água - sem uma área de preservação -, a retificação do córrego "empurrou" a canalização para dentro do parque, para que pudessem ser construídas as avenidas de fundo de vale (figura 65) - Pista Norte, atual Avenida 14 de Setembro e Pista Sul, atual Avenida 11 de Maio - propostas pelo Projeto de um Distrito Industrial. Na fotografia abaixo, a Pista Sul já estava concluída, conectado as áreas de expansão urbana ao parque; cortando a área do futuro parque, a Avenida da Saudade.

Figura 65 - Implementação do Parque do Povo no fundo de vale do Córrego do Veado. Na parte superior, pode-se observar a canalização aberta e o campo de futebol; na parte inferior, um canteiro de obras: terraplenagem, retificação do córrego e construção do canal.

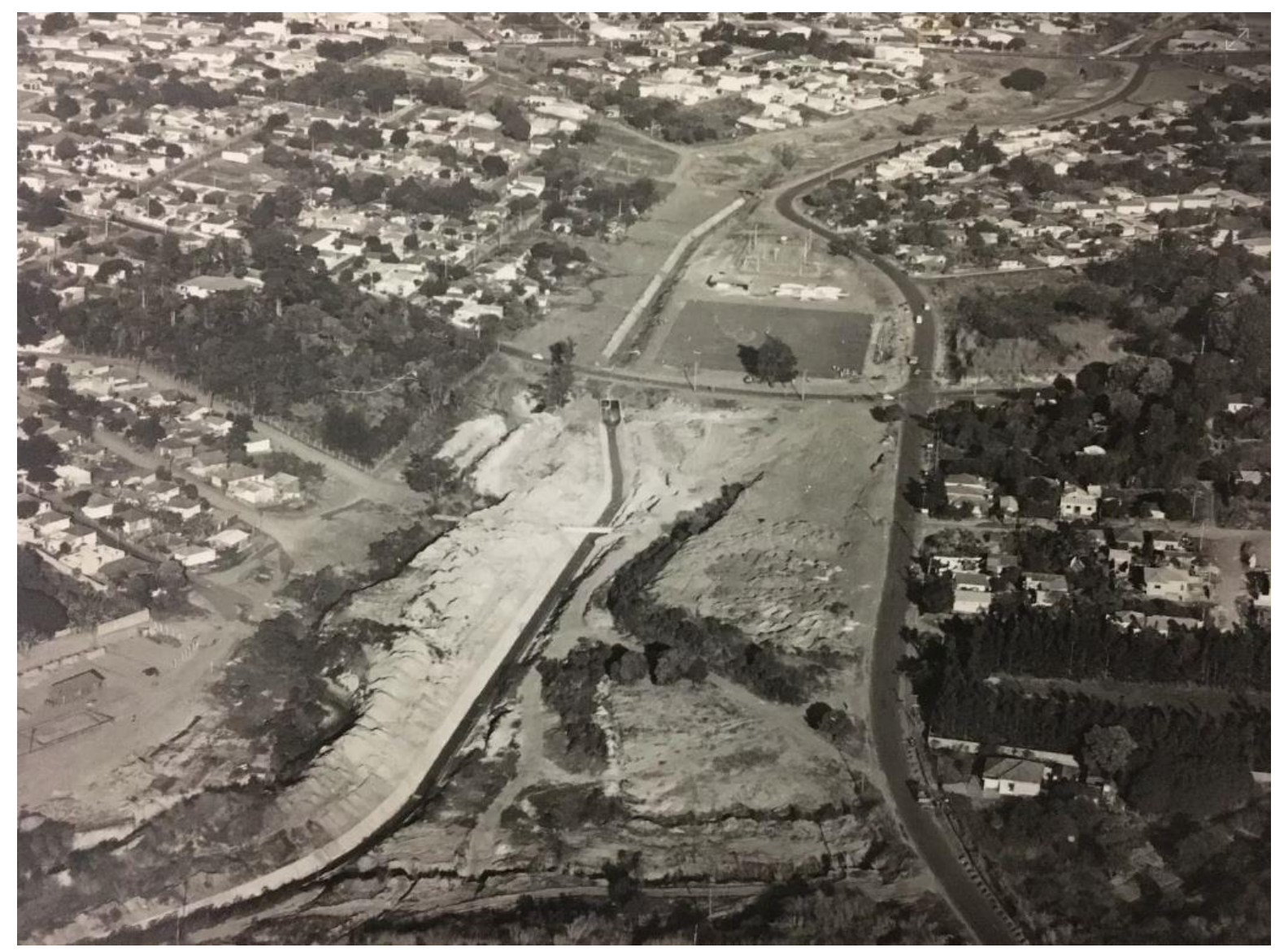

Fonte: arquivo pessoal de Paulo Constantino, ex-prefeito municipal. Disponível em: https://globoesporte.globo.com/sp/presidente-prudente-regiao/noticia/prudente-chega-aos-100-anoscom-o-parque-do-povo-no-auge-da-forma-fisica.ghtml

$\mathrm{Na}$ imagem a seguir (figura 66), tem-se o mesmo trecho do Parque do Povo apresentado na fotografia anterior - com o parque ainda em construção. Observa-se 
a fisionomia de nova centralidade adquirida pelo parque e seu entorno: usos comerciais e de serviços - lojas, restaurantes, bares, posto de combustíveis, hotéis, academias - concentram-se na região atualmente, além do uso residencial e da verticalização, que se deslocou do centro para o entorno do Parque, seguindo os corredores viários mais importantes.

Figura 66 - Parque do Povo, 2016: ao centro, cortando o parque, a Avenida da Saudade.

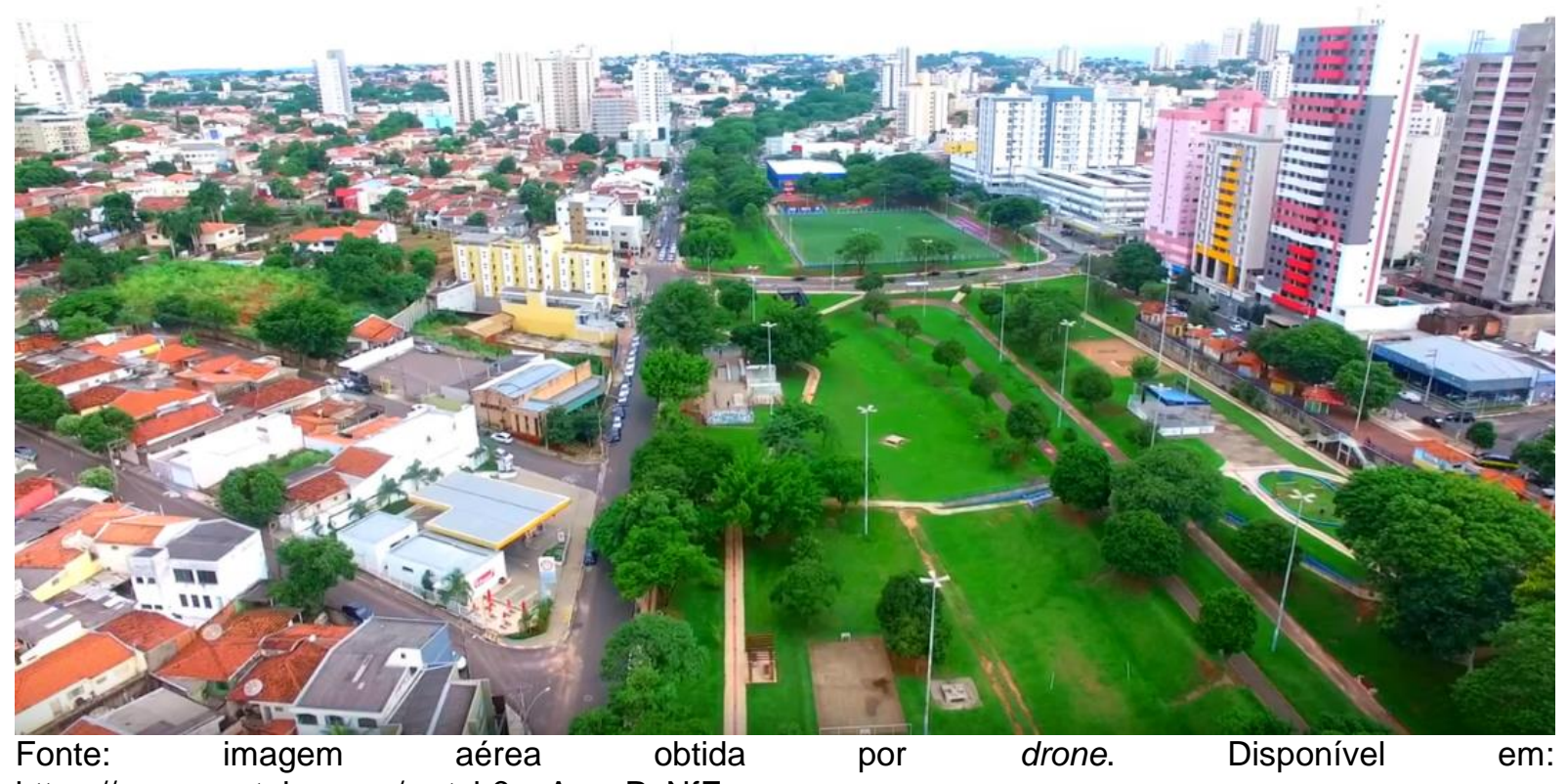

https://www.youtube.com/watch?v=AnzqRyNfFwo

Algumas fotografias da construção do Parque do Povo e Centro Olímpico, também diretriz dos Planos realizados pelo CPEU, testemunham a amplitude da obra que alterava a fisionomia da cidade promovendo um espaço público de grande envergadura e significado. 
Figura 67 - Imagens do projeto "Fundo de Vale".
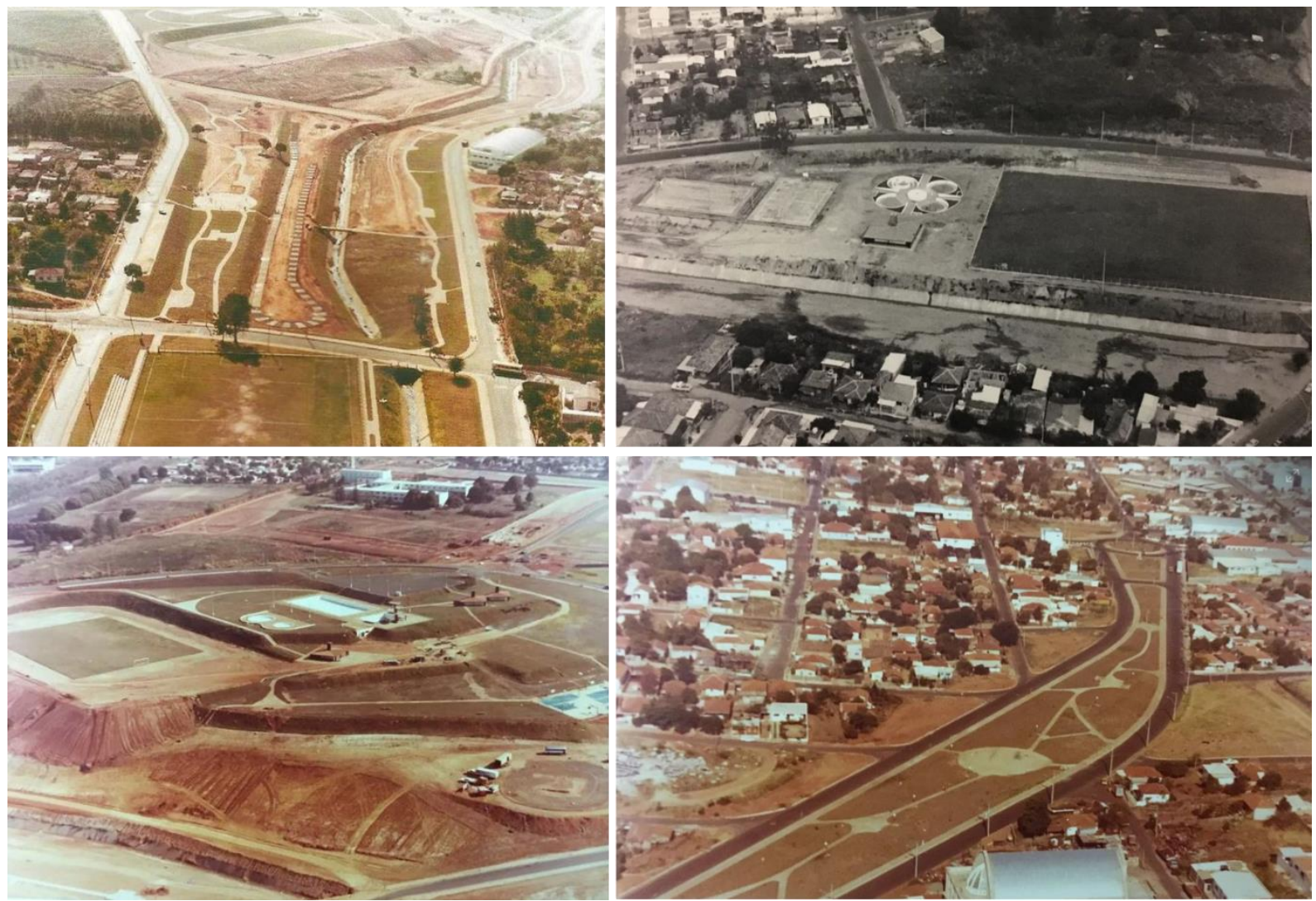

Fotografias superiores: implementação e obras do Parque do Povo. Na fotografia inferior, à esquerda: obras de construção do Centro Olímpico. Na fotografia inferior à direita, trecho inicial do Parque do Povo, projetado com canalização fechada, concluído. Finais dos anos 1970 e início dos anos 1980. Fontes: imagem superior à esquerda: Gustavo Sieplin Junior, reprodução em redes sociais. Demais fotografias: arquivo pessoal de Paulo Constantino, ex-prefeito municipal. Disponível em: https:/globoesporte.globo.com/sp/presidente-prudenteregiao/noticia/prudente-chega-aos-100-anos-com-o-parque-do-povo-no-auge-da-forma-fisica.ghtml

Os únicos trechos em que é possível observar o córrego e sua canalização são os respiros, distribuídos pelo parque e localizados em pontos estratégicos, próximos à confluência com outros córregos e a grandes galerias pluviais provenientes das avenidas (figura 68). 
Figura 68 - Trecho de respiro do Córrego do Veado, no Parque do Povo, ao lado da Avenida da Saudade
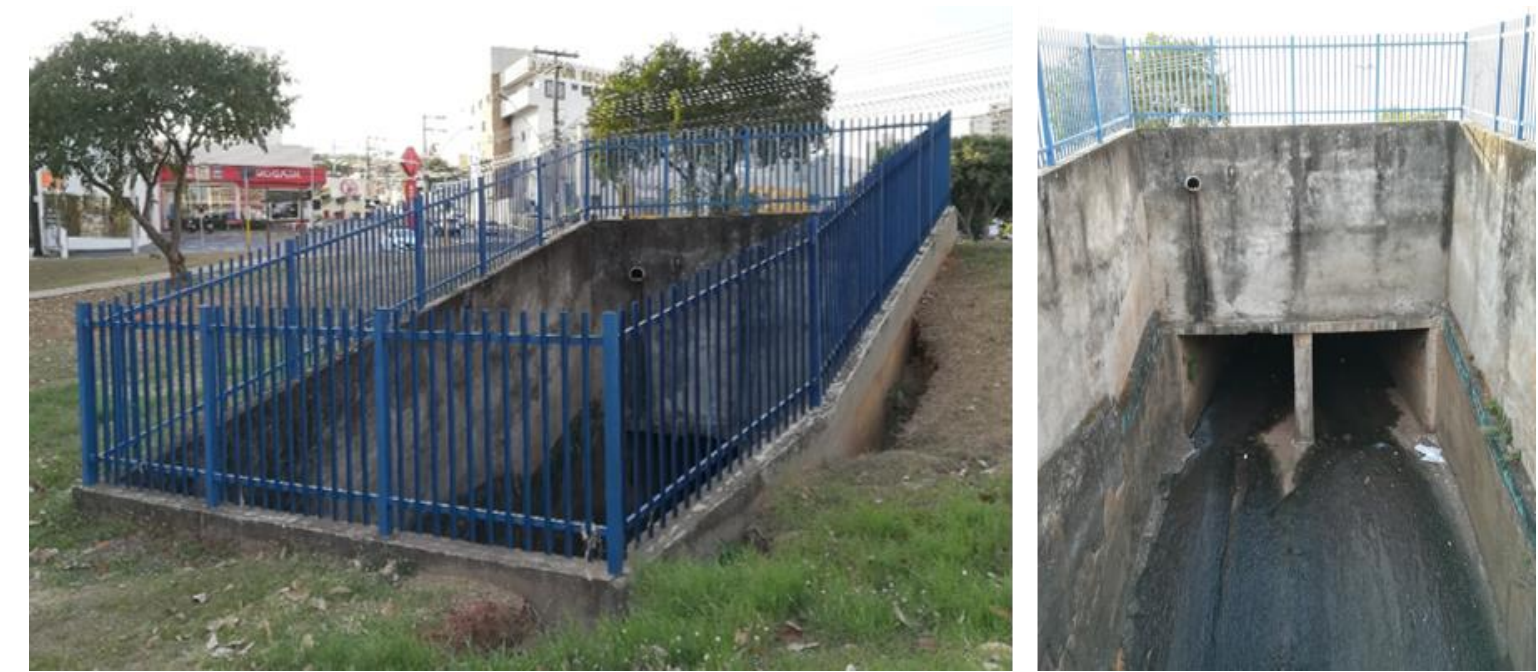

Fonte: arquivo do autor, 2017.

Além dos cursos d'água mostrados acima, as verbas provenientes com o Projeto CURA seriam utilizadas também para canalização fechada de trechos de dois outros córregos: um dos afluentes do Córrego Colônia Mineira (figura 69) - em um trecho conhecido como "Buracão da Raposo Tavares ${ }^{53}$ ou Buracão da Duque de Caxias", nome das ruas de seu entorno, na Vila Geni - sobre o qual avançou a urbanização nas décadas de 1970; e o Córrego da UNESP - no trecho sobre o qual foi instalado o Balneário Municipal Águas Quentes, atual unidade do SESC-SP em Presidente Prudente (figura 70).

53 O Decreto Municipal nº4417/1981 declara de utilidade pública imóveis a serem desapropriados para "obras de saneamento e urbanização do Buracão da Raposo Tavares" (PRESIDENTE PRUDENTE, 1981) 
Figura 69 - Trecho do Córrego Colònia Mineira.
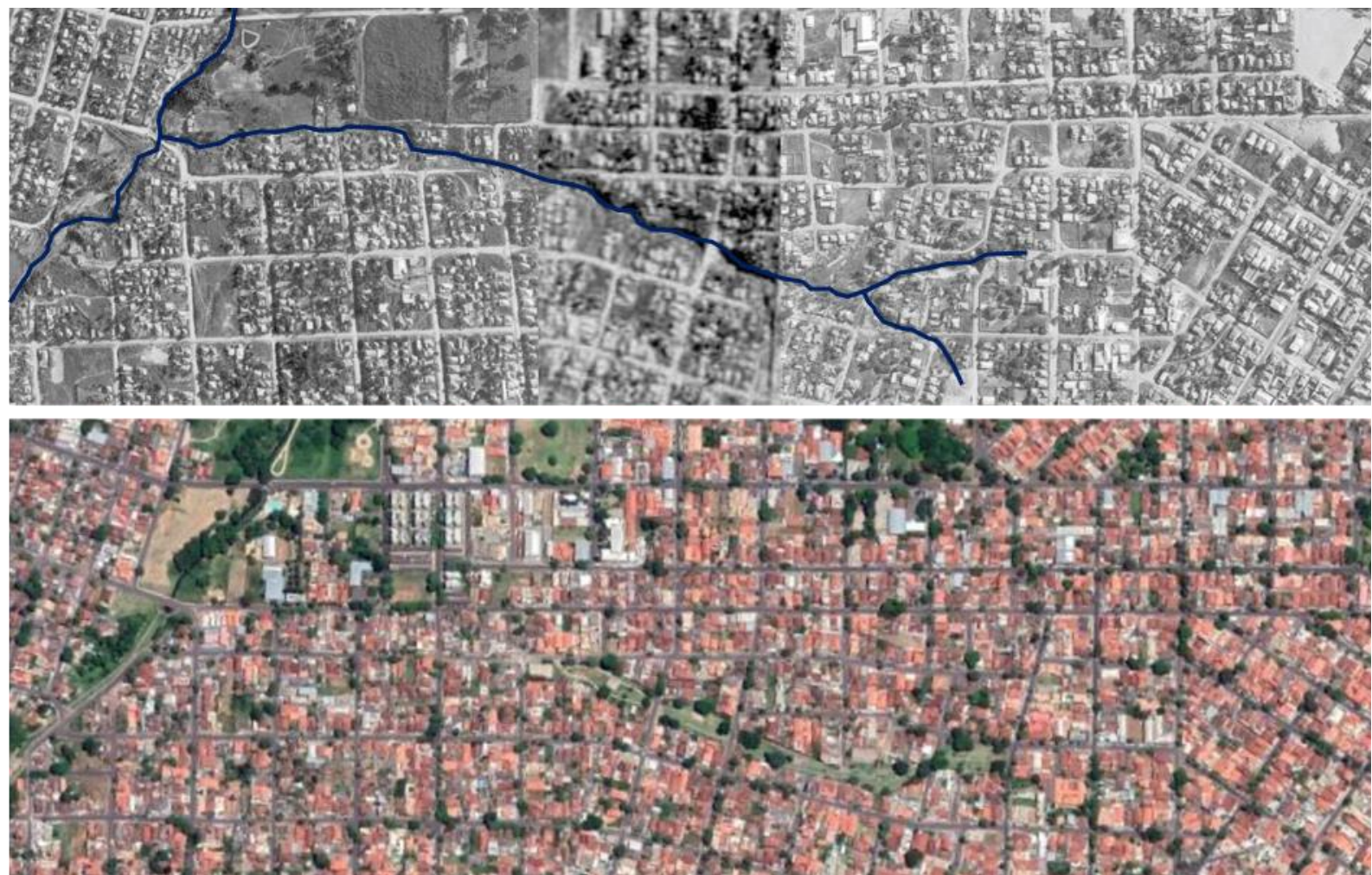

Acima: Braço do Córrego Colônia Mineira, meados da década de 1970. Fonte: recorte de fotografia aérea produzida pela empresa TerraFoto S.A. para a Prefeitura Municipal de Presidente Prudente.

Abaixo: Região do Córrego Colônia Mineira, 2019. Fonte: Google Earth. 
Figura 70 -Trecho do Córrego da UNESP.
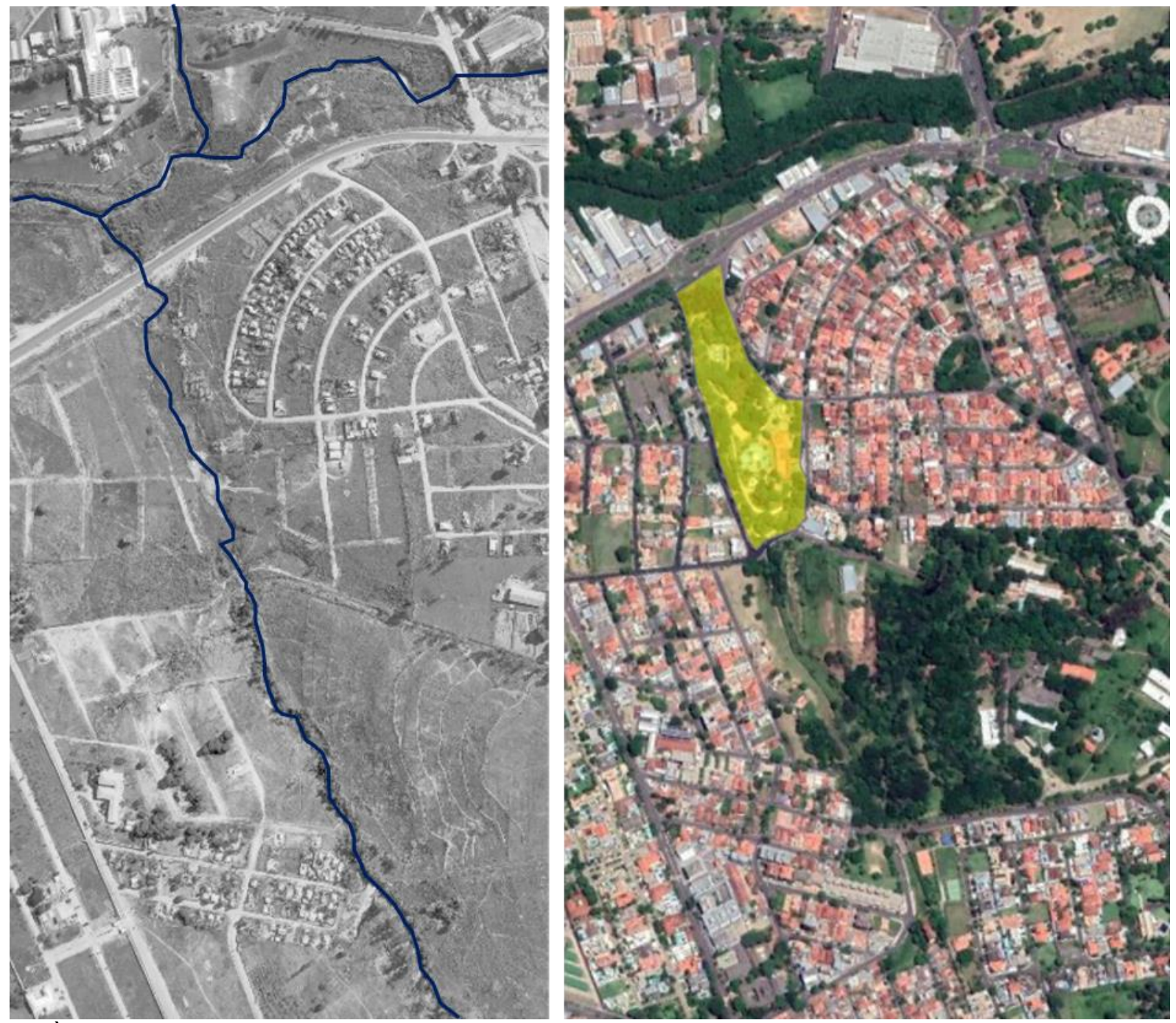

À esquerda: trecho do Córrego da UNESP, meados da década de 1970. Fonte: recorte de fotografia aérea produzida pela empresa TerraFoto S.A. para a Prefeitura Municipal de Presidente Prudente.

À direita: região do Córrego da UNESP, 2019. Em amarelo está destacada a unidade do SESC em Presidente

Prudente, trecho no qual o córrego encontra-se canalizado e tamponado. Fonte: Google Earth.

\subsubsection{Décadas de 1980, 1990 e século XXI}

A década de 1980 pode ser referenciada como período de consolidação das canalizações já realizadas e estruturação do espaço urbano sobre elas. Assim, os fundos de vale e áreas de proteção dos córregos Bacarin e Água Bôscoli são loteados e ocupados, ratificando a impermeabilização de suas áreas. Em relação ao Córrego do Veado, seus espaços imediatamente vizinhos constituiriam o Parque do Povo, que viria a ser inaugurado em 18 de junho de 1982. Em seu entorno, a malha urbana se desenvolveria consideravelmente, com diversos novos loteamentos - inclusive um condomínio fechado. Em 1984, no trecho à jusante do córrego, iniciam-se as obras de construção do Prudenshopping (figura 71) em uma área pública municipal e sobre 
aquilo que as leis distinguiram como áreas de preservação dos Córregos do Veado e Bacarin - um dos espaços de estacionamento do empreendimento foi instalado sobre a confluência destes dois córregos -, evidenciando uma vez mais o tratamento dado pelo poder público aos rios urbanos de Presidente Prudente e suas áreas de preservação.

Figura 71 - Região demarcando a área sobre a qual viria a ser construído o Prudenshopping, meados da década de 1970.

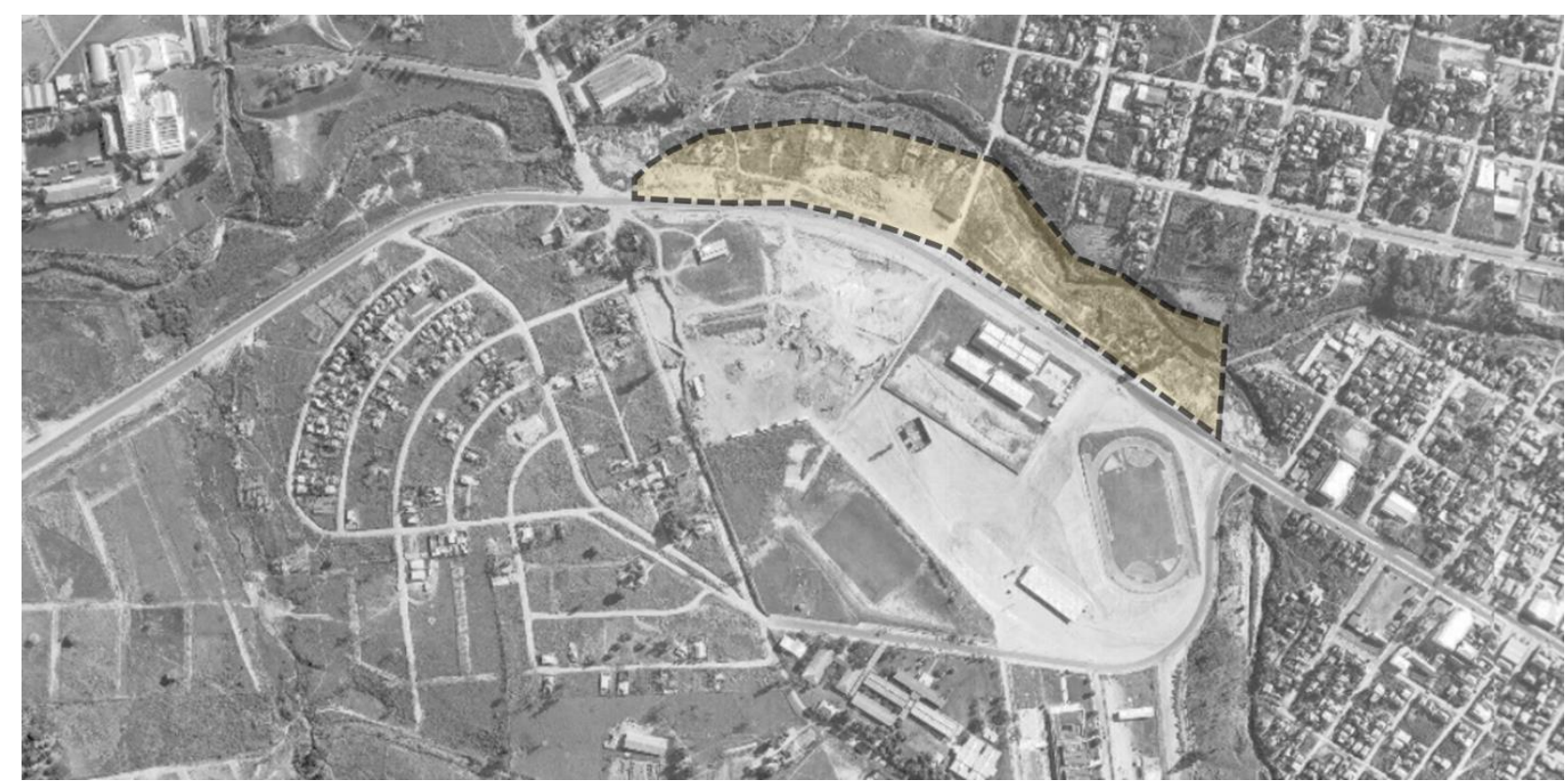

Fonte: recorte de fotografia aérea produzida pela empresa TerraFoto S.A. para a Prefeitura Municipal de Presidente Prudente.

A região formada pelo Parque do Povo, Prudenshopping, UNESP e SESC concentram quatro córregos tributando suas águas no Córrego do Veado: Bacarin, Colônia Mineira, Maracanã e da UNESP (figura 72). Apenas dois anos após a inauguração do centro de lazer e compras, o jornal "O Imparcial" noticiava, em 24 de novembro de 1993, inundação no Prudenshopping, além de alagamento no Tênis Clube e inundação no Parque do Povo ${ }^{54}$. Revelando-se um processo construído e no limite planejado pois figura como contraface de toda a lógica e ocupação urbana, as inundações ocorreriam pós extremas precipitações (MENDONÇA, 2011), revelando o reflexo causado pelo processo de desenvolvimento e a alta impermeabilização da área urbana central e das áreas de preservação dos córregos da Bacia, assim como a canalização e tamponamento de seus cursos d'água.

54 Este não é o primeiro registro de inundação e enchente no Parque do Povo. Relatos anteriores abordam esse conflito acontecendo pouco depois de sua inauguração, ainda na década de 1980. 
Figura 72 - Região de confluência dos córregos do Veado, Bacarin, Colônia Mineira e da UNESP, evidenciando a situação dos córregos na região.
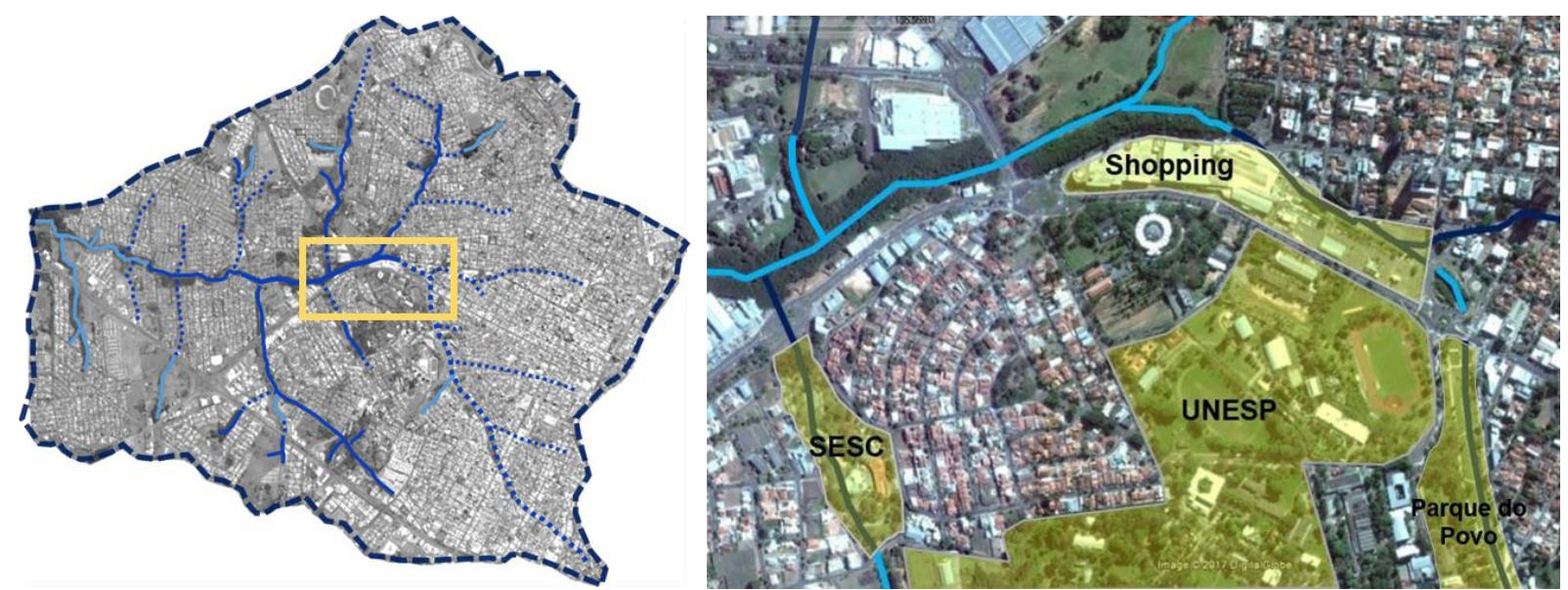

Em azul claro, áreas de canalização aberta; em azul escuro, canalização fechada. Notar que o SESC e o Prudenshopping estão instalados sobre os cursos d'água e suas áreas de preservação e que a área ocupada pelo campus da UNESP corresponde à grande parcela da área permeável na região. Fonte: Google Earth (2019) modificado pelo autor.

Na década de 1990, a partir da aprovação da Política Estadual de Recursos Hídricos - por meio da Lei no 7.663/1991 - a canalização e tamponamento dos córregos ficou condicionada à Outorga De Direitos de Uso dos Recursos Hídricos ${ }^{55}$. Assim, todas as atividades e obras que possam alterar o regime e qualidade dos recursos hídricos passam a depender da autorização dos órgãos estaduais competentes, sendo que a referida Lei tem, por exemplo, como diretrizes: no Artigo $7^{\circ}$ inciso II, a "implantação, conservação, e recuperação das áreas de proteção permanente e obrigatória" (SÃO PAULO, 1991) e também visa, no Artigo $7^{\circ}$ inciso III, ao "zoneamento das áreas inundáveis, com restrições a usos compatíveis nas áreas sujeitas a inundações frequentes e manutenção da capacidade de infiltração do solo" (SÃO PAULO, 1991). No Estado de São Paulo, o órgão gestor e fiscalizador dos recursos hídricos é o DAEE ${ }^{56}$ - Departamento de Águas e Energia Elétrica.

Segundo a pesquisa desenvolvida por Fagundes (2018) e apresentada em sua tese, foi na gestão de Agripino de Oliveira Lima Filho (2002-2004) que os primeiros pedidos referentes a outorgas para canalização de córregos foram protocolados. Assim, córregos na zona leste, no bairro Ana Jacinta e três afluentes da margem direita do Córrego do Veado, em seu trecho urbano final, receberam canalização

\footnotetext{
${ }^{55}$ Regulamentada pelo Decreto Estadual ํㅜ 41.258/1996.

${ }^{56}$ Regulamentado pela Portaria no 717/1996.
} 
fechada. A prefeitura municipal entraria ainda junto ao DAEE com pedido de canalização fechada do Córrego da CECAP e também do Córrego Colônia Mineira.

Segundo Fagundes (2018), à prefeitura municipal foi solicitado pelo DAEE documentação complementar, que justificasse a necessidade de tamponamento dos córregos, uma vez que havia vegetação considerável em seu entorno, nas regiões de nascentes e em sua área de preservação permanente. Em resumo, as justificativas apresentadas pelo prefeito Agripino de Oliveira Lima Filho referiam-se à erosão constante e risco de assoreamento, além do montante de lixo doméstico acumulado no local, irregularmente descartado pelos "moradores inconsequentes" 57 (SÃO PAULO, 2005b, p.88 apud FAGUNDES, 2018, p.190) e também a uma "melhor" urbanização da área, com a interligação de vias entre os bairros do entorno dos córregos e a criação de espaços de lazer (FAGUNDES, 2008). O pedido de canalização fechada para o córrego da CECAP seria deferido; para o Córrego Colônia Mineira, porém, indeferiu-se o pedido por falta de documentação complementar exigida (FAGUNDES, 2018).

Ao justificar a necessidade de execução de canalização fechada dos cursos d'água porque a população seria inconsequente quanto ao descarte de lixo, jogandoo nos córregos e entorno das Áreas de Preservação Permanente, o poder público, representado pelo prefeito, reforça e ratifica as questões trazidas pelo segundo capítulo deste trabalho: educação e cultura de uma população - sobre o que seria desejável para a cidade como qualidade de vida ambiental - se fazem através da vivência dos processos envolvidos - neste caso, principalmente, dos naturais e ecossistêmicos - e do conhecimento sobre as possibilidades de projetos para estes espaços livres que contemplem as questões naturais e sociais. Que tipo de espaço livre público pode desejar uma população que não foi "apresentada" à natureza da cidade e que não entende seus processos e sua importância?

Portanto, é possível compreender a canalização e tamponamento dos cursos d'água como uma política de planejamento adotada pela prefeitura municipal em um determinado período a partir do referencial ao qual tiveram acesso aqueles que lá estão representando o povo. Essa dimensão local dialoga com uma nacional, a partir das práticas de planejamento realizadas sobre os rios urbanos em todo o país, e que se tornaram referencial. Assim, canalizaram-se os córregos da Bacia Hidrográfica do

${ }^{57}$ No trabalho de Fagundes (2018) é possível conferir na íntegra a justificativa técnica entregue ao DAEE pelo prefeito Agripino de Oliveira Lima Filho. 
Córrego do Veado desde o início dos anos 1950, quando o desenvolvimento da malha urbana e os processos de ocupação e produção do espaço entraram em conflito com o meio físico.

Em relação aos processos e solicitações de tamponamento dos cursos d'água em Presidente Prudente, a partir dos anos 2000, Fagundes (2018) evidencia que a situação apenas sofreria um revés a partir do momento em que:

[...] o Ministério Público Estadual, através da Promotoria do Meio Ambiente, representada pelo senhor Nelson Roberto Bugalho ${ }^{58}$, resolveu intervir, recomendando ao DAEE não mais autorizar canalização do tipo fechada na cidade. (FAGUNDES, 2018, p. 190).

Nelson Roberto Bugalho, então promotor de justiça do meio ambiente, envia ao DAEE uma recomendação para que se dê preferência à canalização aberta no município de Presidente Prudente, por motivos entre os quais:

[...] CONSIDERANDO que o regime dos rios e canais depende, em grande parte, da quantidade de chuva, da natureza do solo ou, da rocha sobre os quais eles fluem e também da topografia da superfície, sendo que a preservação dos canais abertos dos corpos d'água e suas respectivas áreas verdes laterais e permeáveis em fundos de vales são importantes para a drenagem das águas pluviais, além de sua relevância para o clima das cidades (Cf. Área Técnica do Ministério Público, fls. 51/59);

CONSIDERANDO ainda que a canalização fechada 1. elimina os elos do ecossistema natural entre alguns de seus elementos (água, solo, vegetação e fauna), seus processos, interações e inter-relações; 2. suprime a noção da existência do corpo d'água existente no local; 3 . descaracteriza a paisagem natural do ambiente urbano, destruindo o referencial e a memória da população; 4. Oculta os elementos que caracterizam a área de preservação permanente (Código Florestal, artigo 2), propiciando ocupações indevidas e ilegais; 5 . dificulta sua manutenção e proporciona maiores intervenções quando estas são executadas; 6 . dificulta o monitoramento da qualidade das águas; 7. ocasiona danos ambientais e econômicos quando ultrapassa a vazão prevista; 8. facilita a indevida ocupação das áreas protegidas, geralmente transformando-as em estacionamentos ou pontos de comércio (Cf. Área Técnica do Ministério Público, fls 51/59);

E, CONSIDERANDO, FINALMENTE, que a preservação dos atributos ambientais dos cursos d'água e de suas áreas de preservação permanente, bem como da paisagem natural urbana e do referencial de natureza da população estão na dependência da observância da melhor alternativa técnica, e que esta contempla a construção de canais abertos, [...] (SÃO PAULO, 2005d, p.55-57 apud FAGUNDES, 2018, p. 193, grifo nosso).

\footnotetext{
${ }^{58}$ Nelson Roberto Bugalho é o atual Prefeito de Presidente Prudente, no mandato 2017-2020, e à época era Promotor de Justiça do Meio Ambiente em Presidente Prudente.
} 
Fagundes (2018) relata ainda que, mesmo após a recomendação encaminhada para que fosse considerada como melhor alternativa a construção de canalização aberta nos córregos, a prefeitura continuou solicitando ao DAEE pedidos de outorga para obras de canalização fechada em Presidente Prudente. A partir de então, como já havia parecer anterior, o DAEE criou, em 2005, uma normativa, em toda a sua abrangência estadual, recomendando a não outorgar canalizações fechadas em rios, a menos que, além das razões técnicas, sejam casos excepcionais em que haja justificativa de utilidade pública ou interesse social para tal ato.

Fagundes (2018) teve acesso e analisou quinze documentos referentes a outorgas de canalização solicitadas pela prefeitura municipal de Presidente Prudente entre os anos de 2002 e 2014 junto ao DAEE; daqueles, foram deferidas as seguintes canalizações - inseridas na Bacia Hidrográfica do Córrego do Veado: Córrego do Saltinho, Córrego Maracanã e afluentes, Córrego da UNESP, Córrego Colônia Mineira e afluentes e Córrego do Veado (trecho intermediário e final). A figura 73 apresenta a situação dos rios, fundos de vale e espaços livres em trechos da bacia hidrográfica analisada. 
Figura 73 - Rios, fundos de vale e espaços livres.
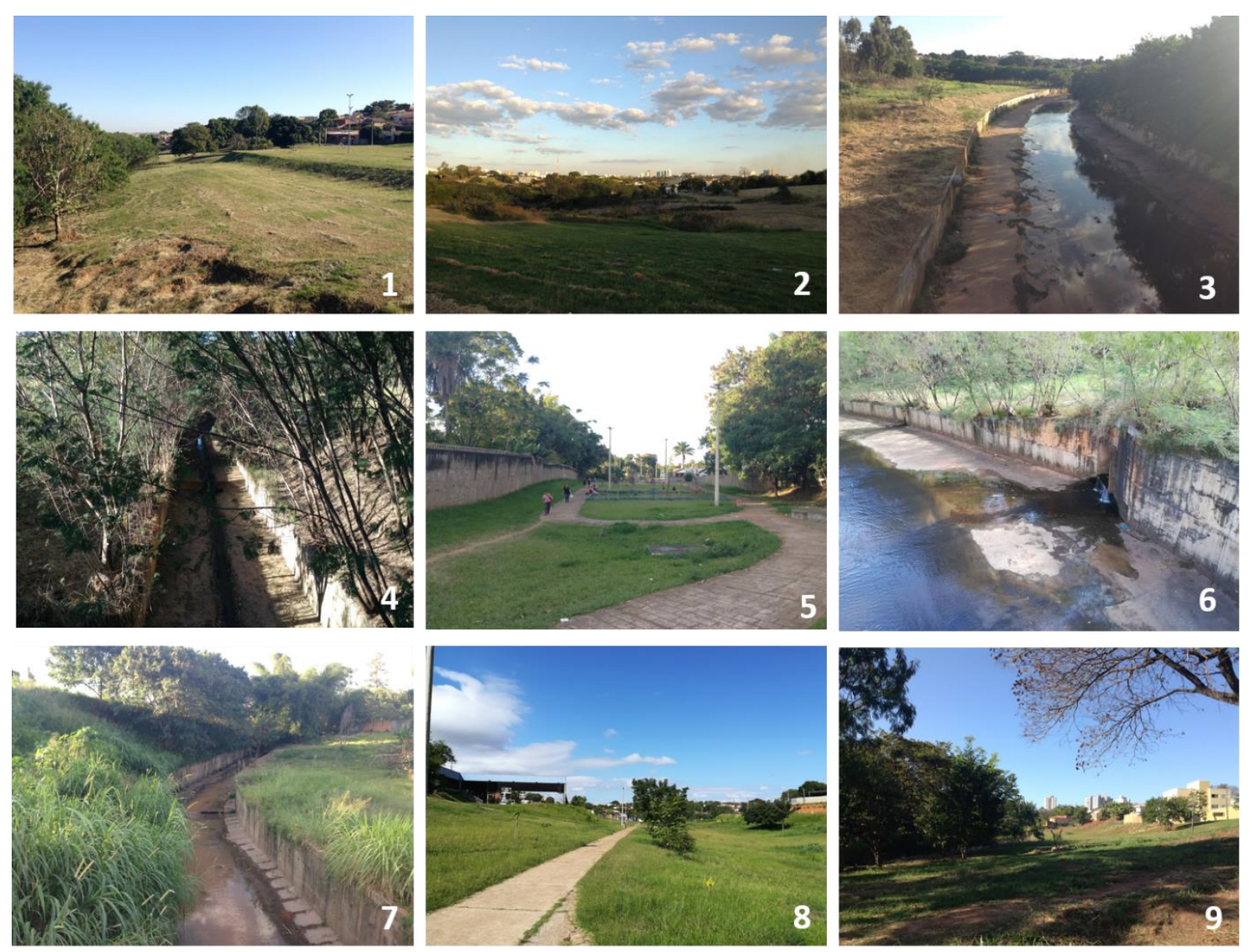

1 - Fundo de vale e espaços livres do Córrego Saltinho; 2 - Região de nascente de um afluente do Córrego Maracanã, ambos canalizados; 3 - Córrego do Veado, canalização aberta; 4 - Córrego do Saltinho; 5 - Espaço livre sobre trecho de canalização fechada do Córrego Colônia Mineira; 6 - Afluente da margem direita tributando no Córrego do Veado; 7 - Córrego Colônia Mineira, canalização aberta; 8 - Espaço livres sobre canalização fechada de afluente da margem esquerda do Córrego do Veado, Avenida Ana Jacinta; 9 - Espaço livre e área de preservação permanente do Córrego da UNESP. 2018. Fonte: arquivo do autor, trabalho de campo.

No mapa apresentado para a atual situação dos córregos na Bacia Hidrográfica do Córrego, os trechos que não se encontram canalizados, sendo um afluente do Córrego Colônia Mineira e um do Córrego Saltinho, tiveram seus pedidos indeferidos, respectivamente, por conter área de preservação permanente com vegetação em estágio avançado no primeiro e por ter sido feito um pedido de canalização fechada para o segundo. O trecho final (figura 74) do Córrego do Veado, pouco antes de suas águas unirem-se ao Córrego do Limoeiro, teve o pedido de outorga autorizado em 2014, embora não tenha sido realizada a obra por questões financeiras, segundo a prefeitura municipal. 
Figura 74 - Transição entre a canalização aberta e o trecho não canalizado - mas já autorizado - do Córrego do Veado.

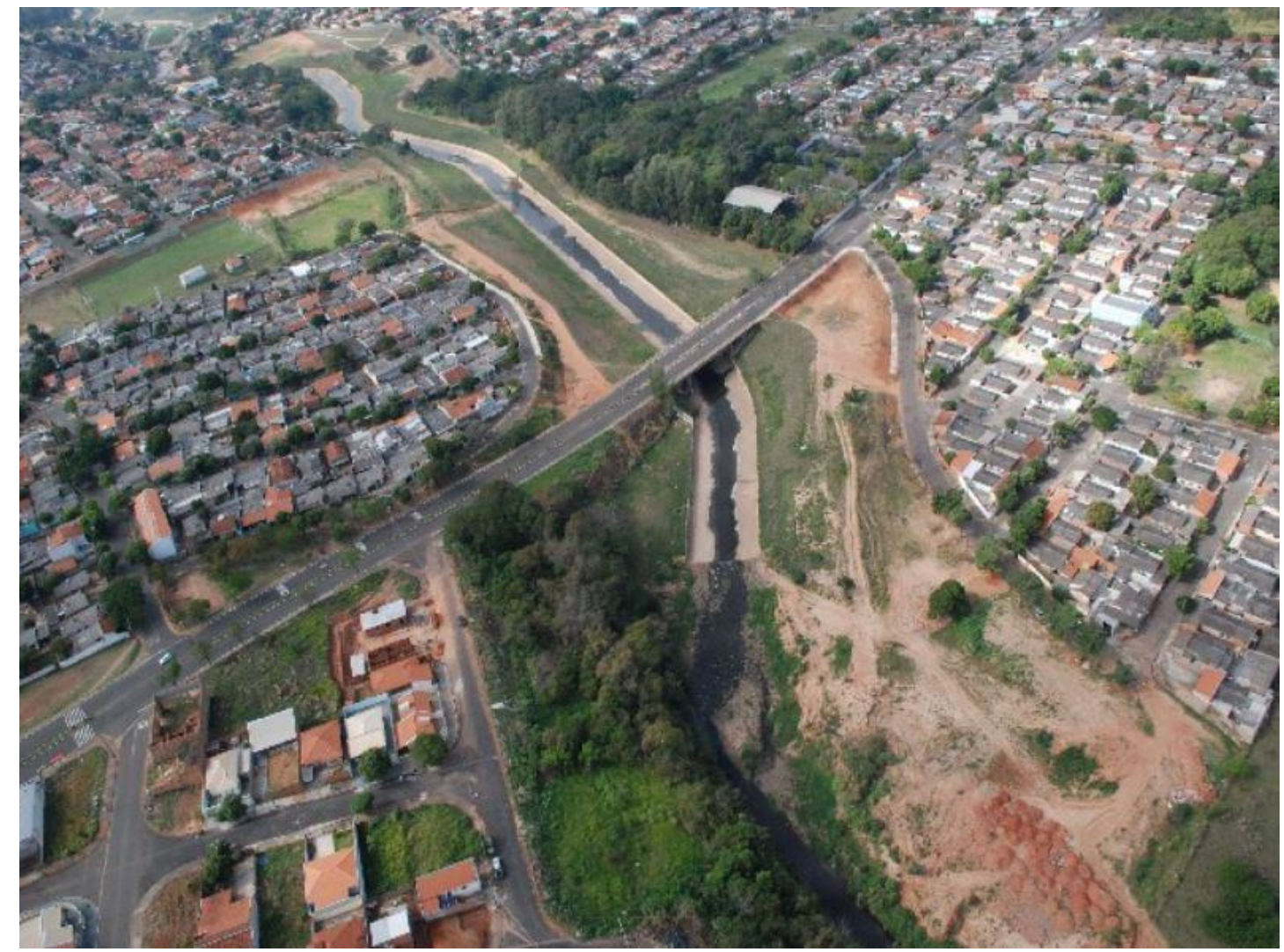

Fonte: Prefeitura Municipal de Presidente Prudente (2010). Disponível em:

http://www.presidenteprudente.sp.gov.br/site/noticias.xhtml;jsessionid=363DDB87A7282432A2567EB702D16FC $E$ ?cod=7844\&imprimir=true

Quanto às demais canalizações, realizadas durante as duas primeiras décadas deste século, foram realizadas através de financiamentos junto aos órgãos e programas federais, como o Programa Saneamento para Todos e o Programa de Aceleração do Crescimento (PAC), através do qual, lançado pelo governo federal em 2007, a prefeitura municipal captaria recursos da ordem de $R \$ 60$ milhões para canalizar 12,2 quilômetros de fundos de vale em um tempo recorde de dois anos (PRESIDENTE PRUDENTE, 2010).

As sequências de imagens a seguir apresentam os fundos de vale e os locais das canalizações, comparando fotos aéreas das décadas de 1970 e 1990 a imagens de satélite mais recentes, 2019.

\section{Córrego Maracanã e Córrego Colônia Mineira (figura 75)}


Figura 75 - Região do Córrego Maracanã (à esquerda) e Córrego Colônia Mineira (à direita), em diferentes décadas.

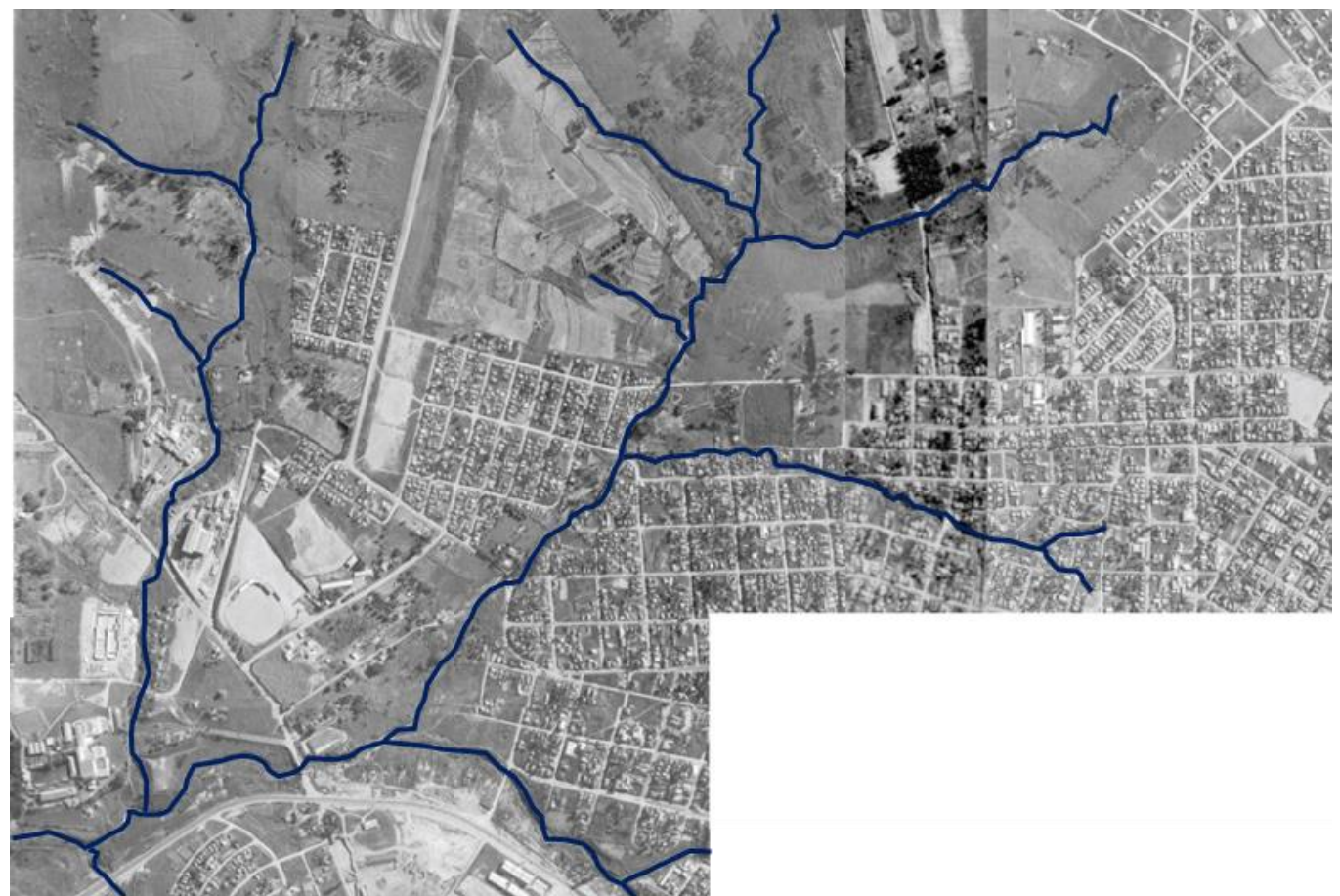

Região do Córrego Maracanã (à esquerda) e Córrego Colônia Mineira (à direita), meados da década de 1970. Fonte: recorte de fotografia aérea produzida pela empresa TerraFoto S.A. para a Prefeitura Municipal de Presidente Prudente.

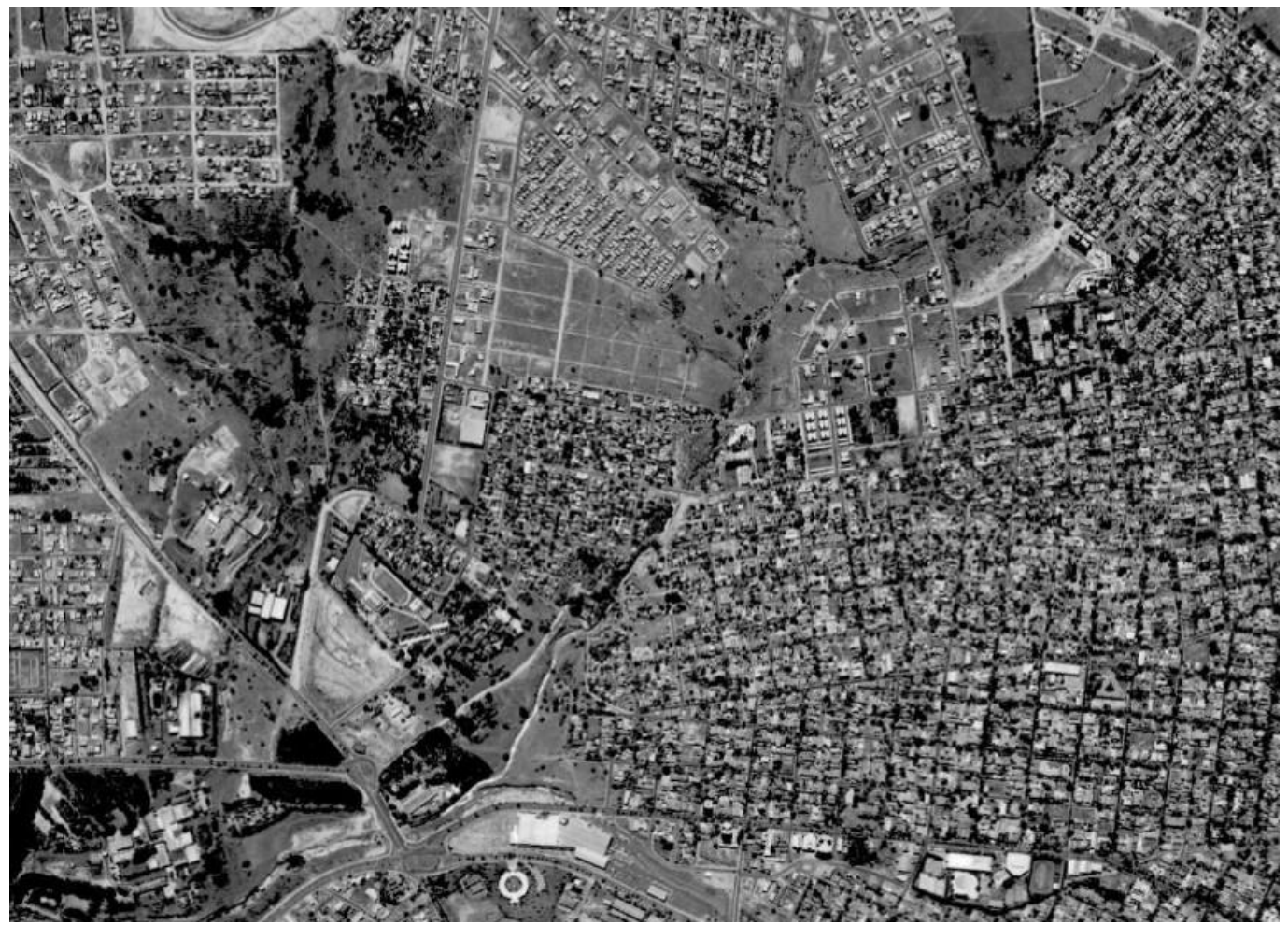

Região do Córrego Maracanã (à esquerda) e Córrego Colônia Mineira (à direita), 1995. Fonte: recorte de fotografia aérea produzida pela empresa BASE S.A. para a Prefeitura Municipal de Presidente Prudente. 


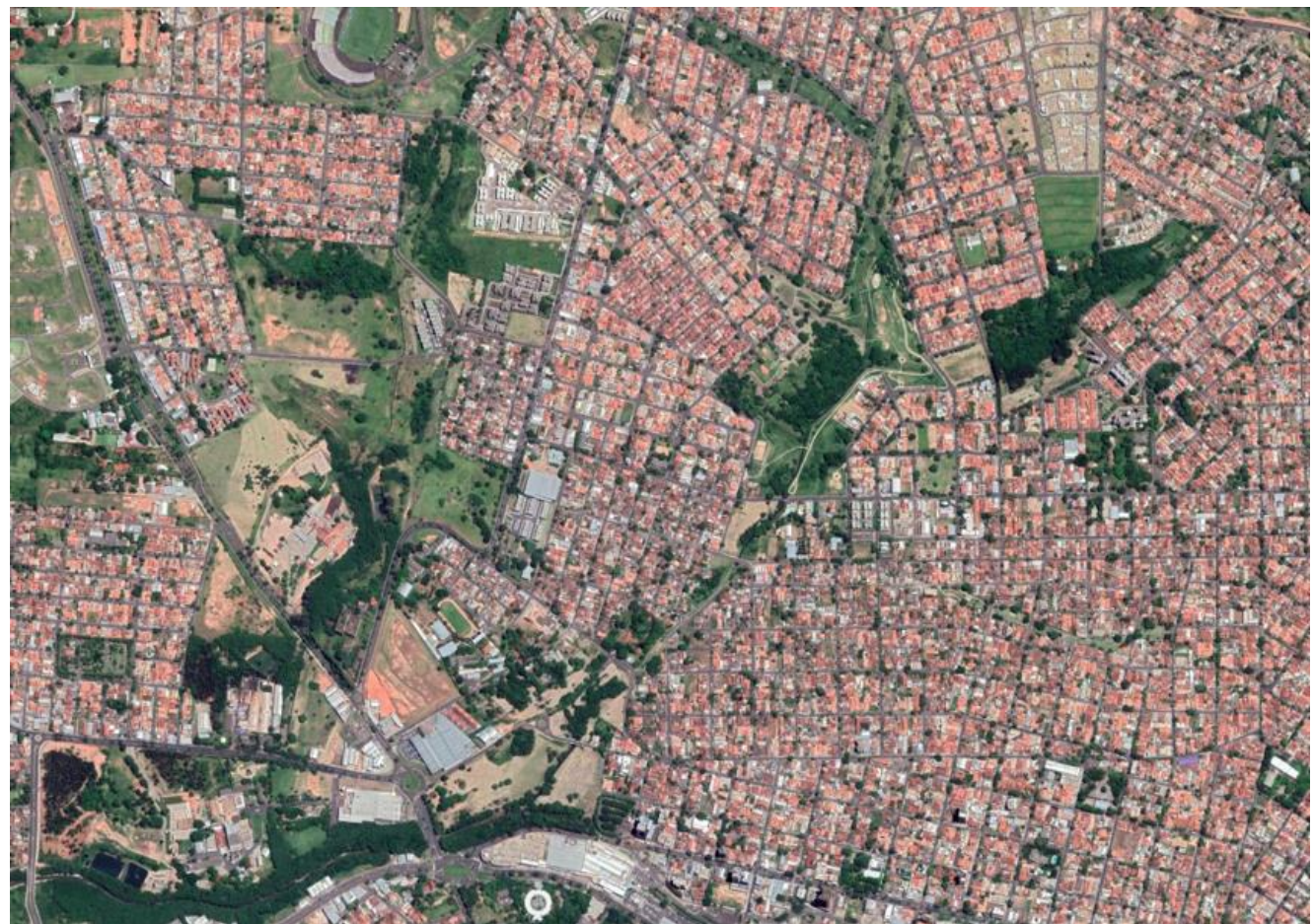

Região do Córrego Maracanã (à esquerda) e Córrego Colônia Mineira (à direita), 2019. Fonte: Google Earth.

\section{Córrego do Saltinho (figura 76)}

Figura 76 - Região do Córrego do Saltinho, em diferentes décadas.

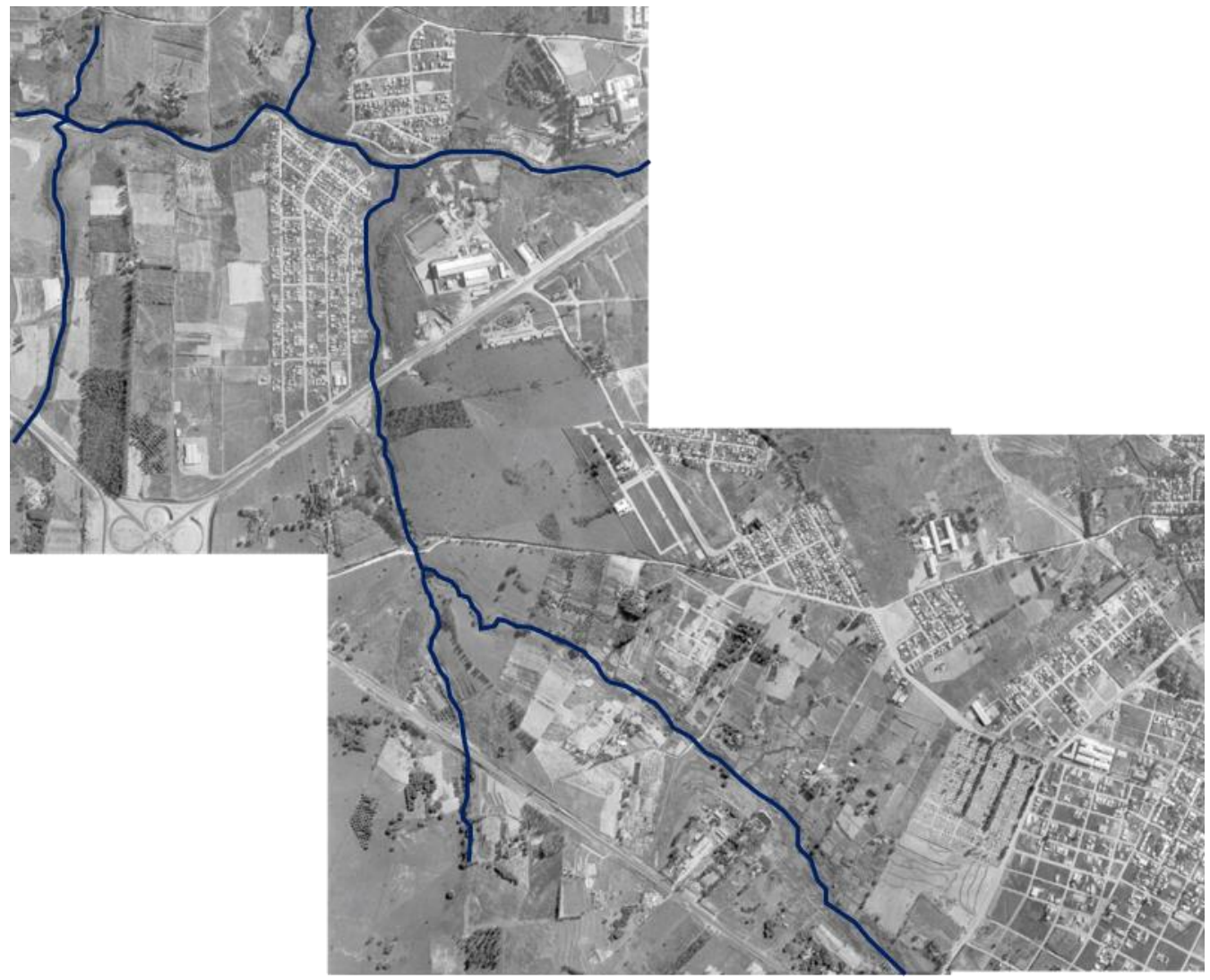

Região do Córrego do Saltinho, meados da década de 1970. Fonte: recorte de fotografia aérea produzida pela empresa TerraFoto S.A. para a Prefeitura Municipal de Presidente Prudente. 


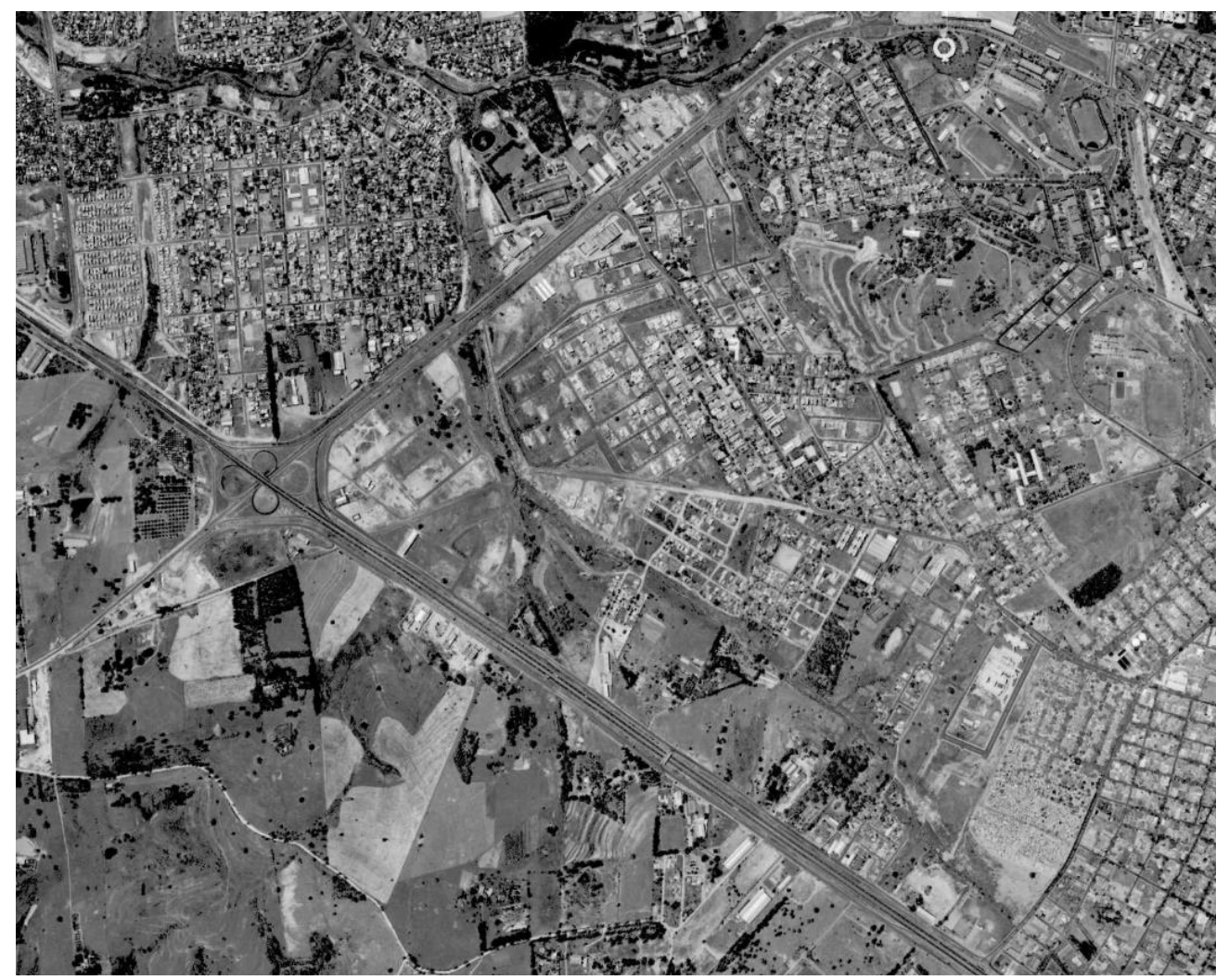

Região do Córrego do Saltinho, 1995. Fonte: recorte de fotografia aérea produzida pela empresa BASE S.A. para a Prefeitura Municipal de Presidente Prudente.

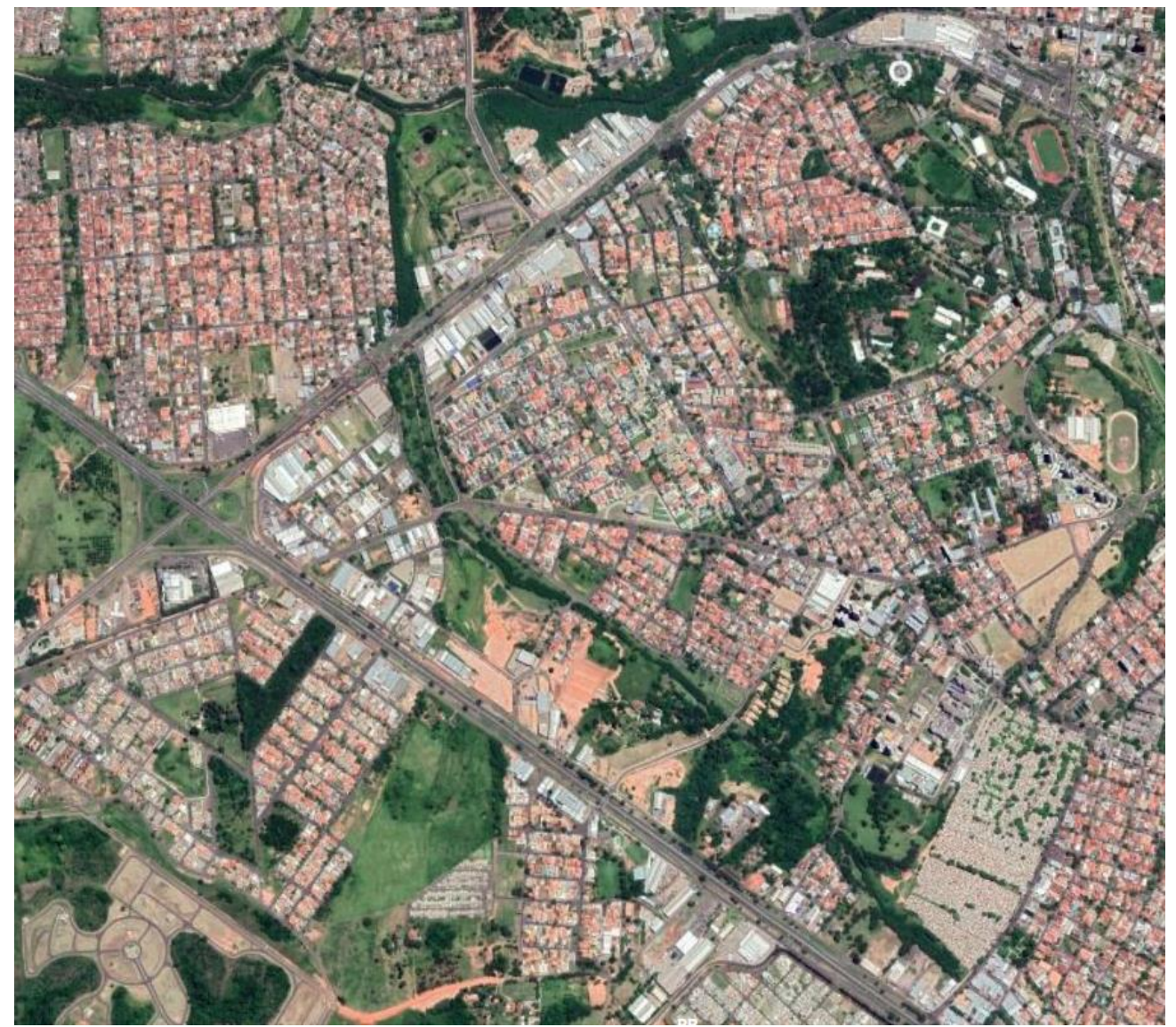

Região do Córrego do Saltinho, 2019. Fonte: Google Earth. 


\section{Córrego do Veado e afluentes - trecho final - e Córrego da UNESP (figura 77)}

Figura 77 - Região do Córrego do Veado e Córrego da UNESP, em diferentes décadas.

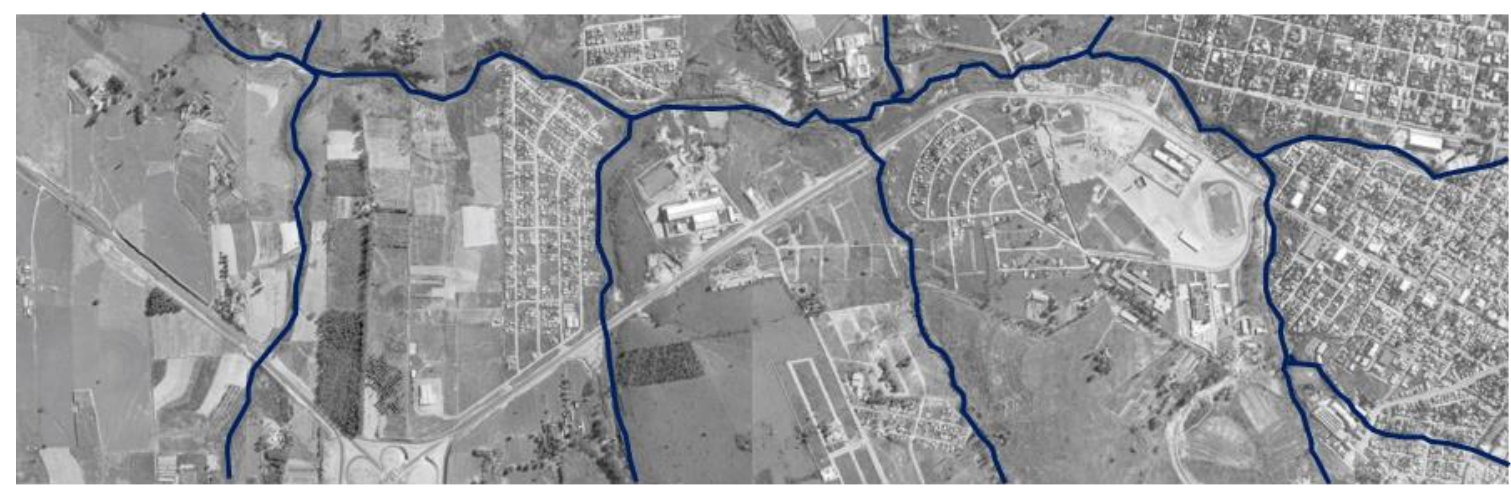

Região do Córrego do Veado e Córrego da UNESP, meados da década de 1970. Fonte: recorte de fotografia aérea produzida pela empresa TerraFoto S.A. para a Prefeitura Municipal de Presidente Prudente.

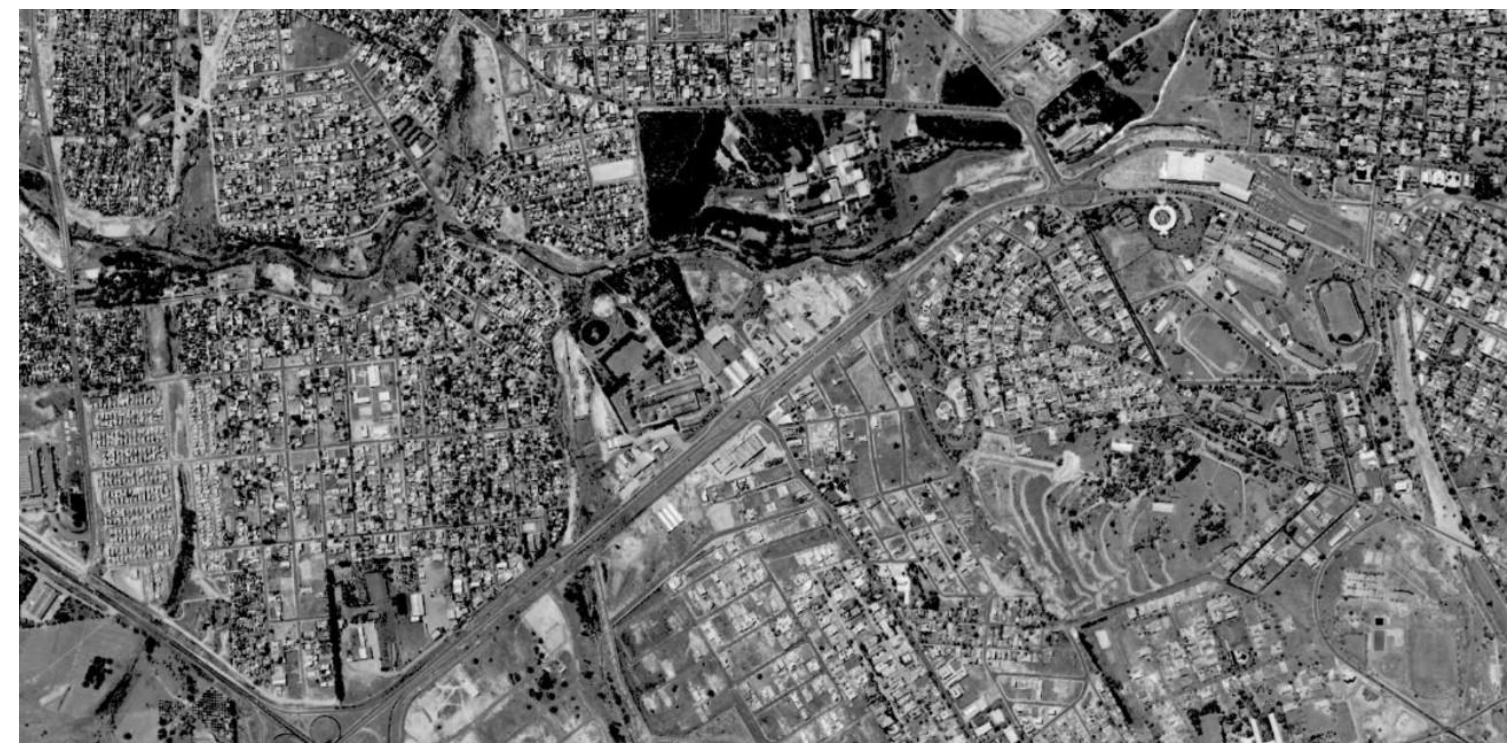

Região do Córrego do Veado e Córrego da UNESP, 1995. Fonte: recorte de fotografia aérea produzida pela empresa BASE S.A. para a Prefeitura Municipal de Presidente Prudente. 


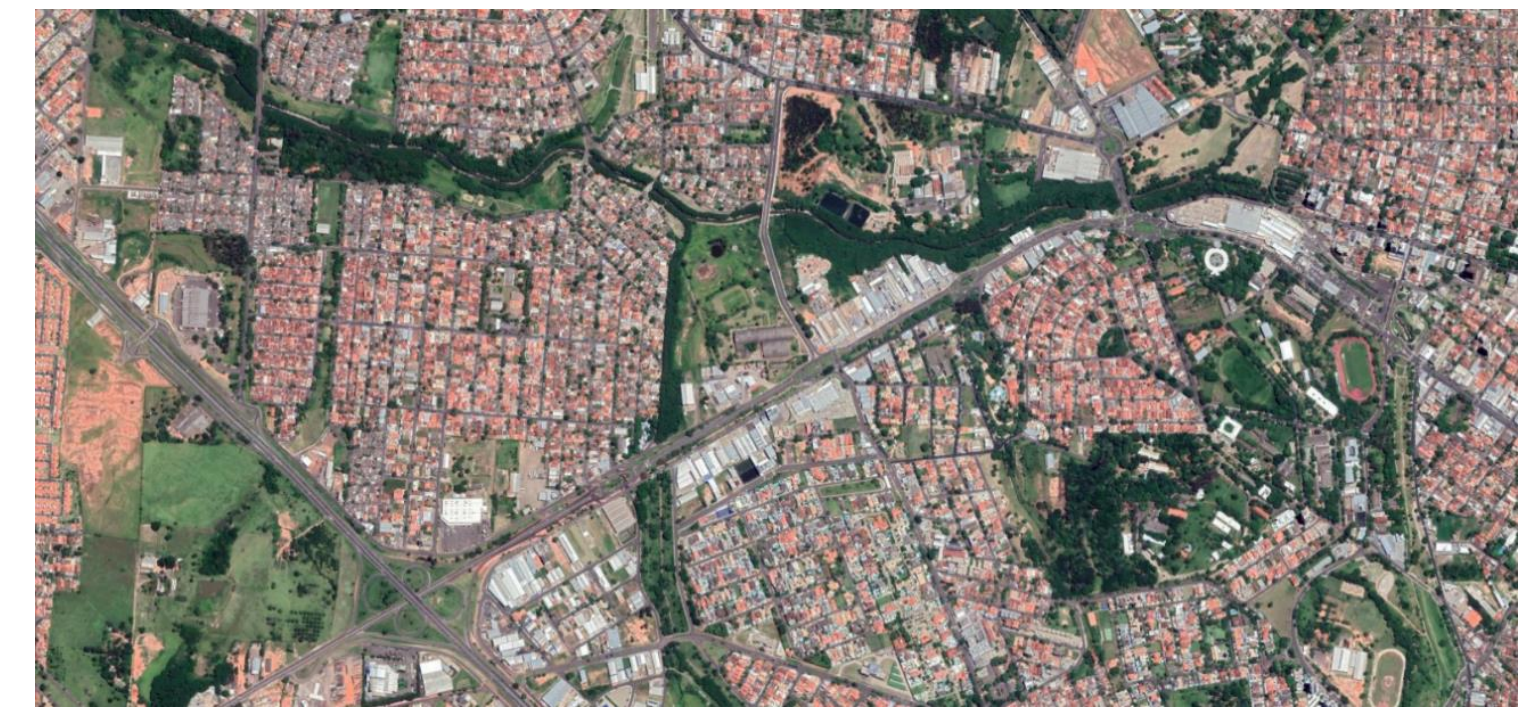

Região do Córrego do Veado e Córrego da UNESP, 2019. Fonte: Google Earth.

Ao comparar as imagens em diferentes temporalidades, é possível observar que houve um ganho considerável de vegetação e massas arbóreas, principalmente nas faixas referentes às áreas de preservação permanente dos córregos e que estas, salvo algumas exceções, foram respeitadas. Percebendo o potencial sistema de espaços livres, (SEL), que as imagens conformam, nota-se a possibilidade de ser elaborado um planejamento com a paisagem tirando partido do sistema de espaços livres formado por esses "corredores verdes e azuis" que associam os espaços livres ainda verdes e os corpos de água de uma bacia hidrográfica que é completamente urbana.

As imagens de 1995 evidenciam ainda que o desenvolvimento da malha urbana ocorreu de forma pouco contínua, contudo, essa fragmentação apresenta loteamentos e maior efetividade de ocupação dos terrenos nas regiões dos Córregos Colônia Mineira e Maracanã e trechos finais do Córrego do Veado do que propriamente entre o Córrego do Veado na região central da cidade, ou o trecho que se relaciona à rodovia Raposo Tavares - conhecida como região "problema" na década de 1970, uma vez que a rodovia, funcionando como barreira física ao desenvolvimento territorial e econômico da cidade foi motivadora das diversas ações políticas e de planejamento que culminaram na canalização do Córrego do Veado e seus afluentes à época.

Outra constatação importante é aquela que observa que o trecho inicial do Córrego do Veado, Córrego da UNESP e Córrego do Saltinho tiveram suas regiões altamente impermeabilizadas e isso se amplia nos últimos vinte e cinco anos, pois a despeito da presença de loteamentos e bairros há, aproximadamente, cinquenta anos, 
a fisionomia e o padrão de ocupação se alterou: a crescente impermeabilização corrobora um movimento que acontece em muitos pontos da cidade, mas que nesse território contribuirá com o aumento da mancha de inundação.

De todas as obras de "urbanização de fundo de vale" e canalizações de córregos, a única que apresentou um processo de continuidade no planejamento urbano e de paisagem foi a do Córrego Colônia Mineira, que recebeu, em uma área de aproximadamente 160 mil metros quadrados, um Parque Ecológico (figura 78).

Anunciado pela Prefeitura em 2012 e inaugurado em 14 de maio de 2016, o Parque Ecológico São Lucas e São Matheus (figura 79) recebeu um investimento de pouco mais de $\mathrm{R} \$ 3$ milhões, com recursos oriundos do FID (Fundo de Interesses Difusos) e foi instalado em área mais afastada da região central, na qual a concentração de renda e poder aquisitivo são menores. Conta com ciclovias, pistas para caminhada e trilha, playground, pista de skate, quadra de vôlei de areia, equipamentos de ginásticas e campo de futebol society, entre outros (PRESIDENTE PRUDENTE, 2014).

Figura 78 - Localização do Parque Ecológico em comparação com o Parque do Povo.

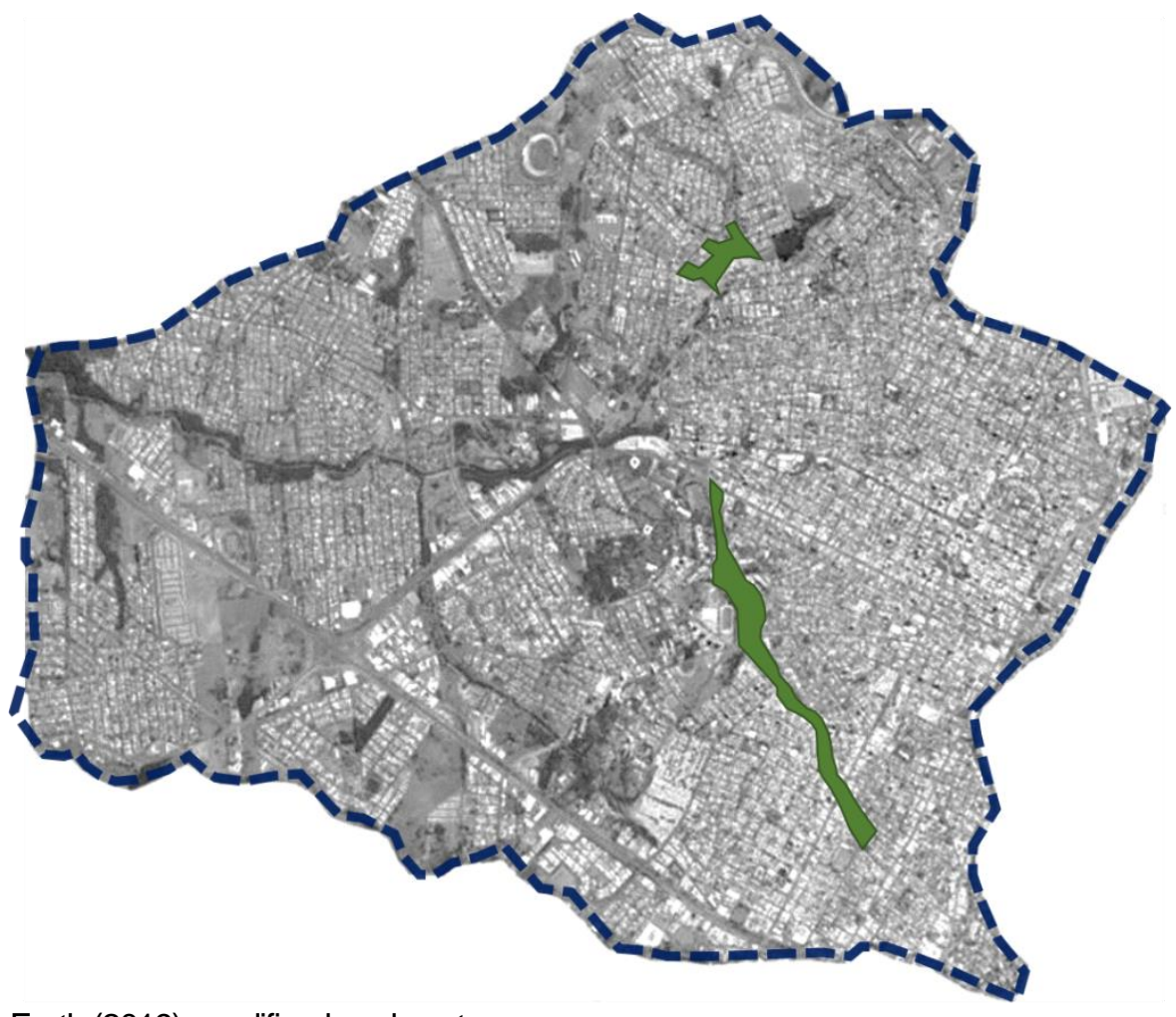

Fonte: Google Earth (2019), modificado pelo autor.

Apesar de ser cercado por alambrados e carecer de manutenção frequente quando comparado ao Parque do Povo - o espaço cumpre sua função de área 
permeável e proteção permanente aos córregos e seus afluentes - e nascentes - que se encontram dentro do parque; também cumpre sua função como espaço de lazer e inserção da população no contato com a natureza e com os córregos urbanos. Portanto, pode funcionar como um primeiro teste - para um futuro sistema de espaços livres - para a educar a população sobre paisagens possíveis, através de sua aproximação com os processos que sustentam a vida.

Figura 79 - Comparação entre o projeto e a implantação do Parque Ecológico.
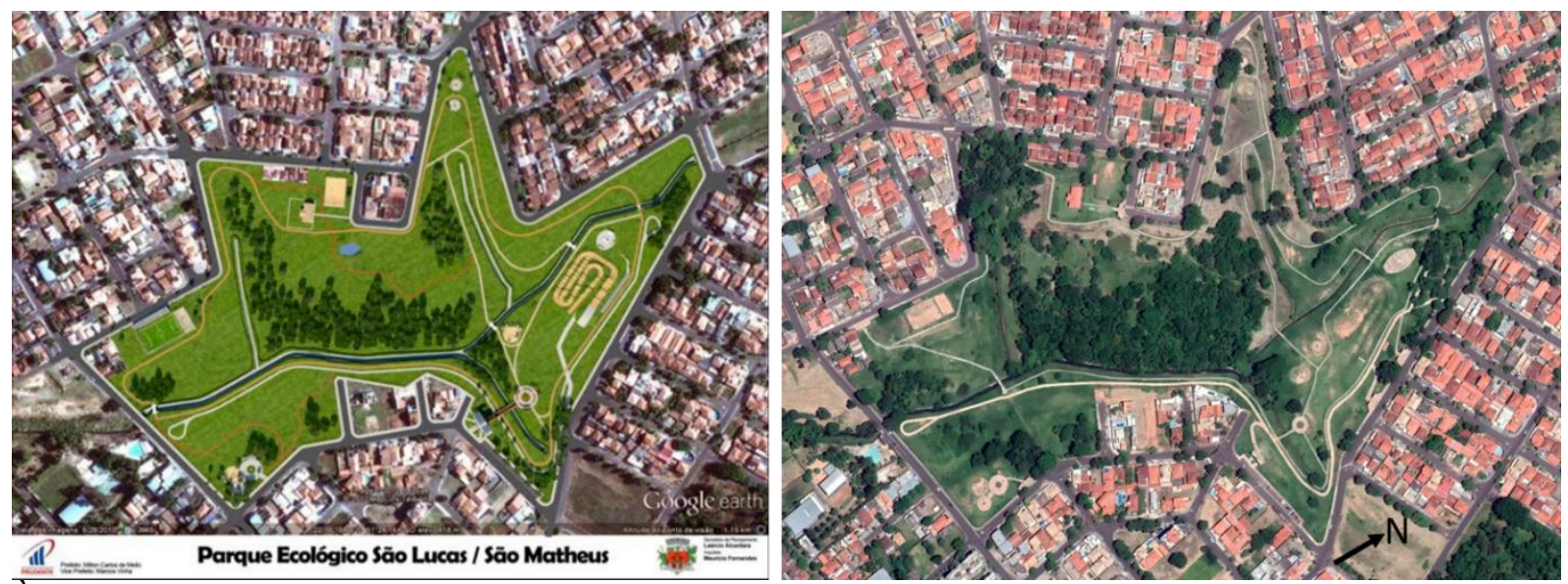

À esquerda: projeto apresentado pela prefeitura municipal para o Parque Ecológico São Lucas e São Matheus,

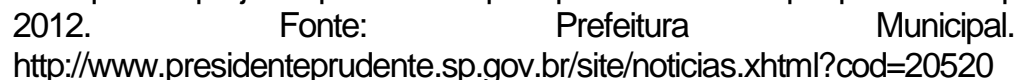

À direita: situação e implantação atual do Parque, 2019. Fonte: Google Earth

Nos demais córregos que receberam projetos de canalização - aberta ou fechada - alguns contam com "academias ao ar livre" e outros com quadra e/ou campo de futebol. Em alguns dos processos mais recentes, procedeu-se ao cumprimento da legislação atual, que indica a obrigatoriedade de cercamento das áreas de preservação permanente. Os rios estão visíveis; os processos ecológicos e ecossistêmicos em seus espaços, porém, são mantidos afastados da população. A invisibilidade, de certa forma, continua. 


\section{CAPÍTULO V - WORKSHOP "PLANEJAR COM A PAISAGEM": UMA ALTERNATIVA PARA SE PENSAR O PLANEJAMENTO}

Se no primeiro capítulo se discutiram as relações entre rios e cidade e processos de planejamento no Brasil; o segundo capítulo apresentou processos e metodologias de planejamento com a paisagem que desde o século XIX evidenciam a necessidade de se pensar as cidades como parte da natureza e de seus processos; o terceiro capítulo apresenta o histórico de desenvolvimento de uma cidade que nasceu no século $X X$, mas tem seus processos de planejamento urbanos regidos pela máxima de que as águas urbanas são um problema técnico a ser contornado, sob essa perspectiva, os rios urbanos são galerias, e que os processos ecossistêmicos não estão na pauta desse tipo de planejamento. O quarto capítulo por sua vez, apresentou um recorte específico de uma bacia hidrográfica completamente urbana e a relação histórica entre seus rios, cidade e espaços livres, através de uma reflexão elaborada sobre uma série de imagens comparativas. Neste quinto capítulo, será apresentada uma metodologia de planejamento baseada nos conceitos, planos, processos e projetos apresentados no segundo capítulo e que tem como estudo de caso a bacia estudada.

Desenvolvido no mês de maio de 2019, em Presidente Prudente - SP, com alunos do $3^{\circ}$ ano do curso de graduação em Arquitetura e Urbanismo da Faculdade de Ciências e Tecnologia da Universidade Estadual Paulista (FCT-UNESP), por intermédio da Prof ${ }^{a}$. Dr ${ }^{\mathrm{a}}$. Arlete Maria Francisco, em parceria com a Prof ${ }^{\mathrm{a}}$. Dra ${ }^{\mathrm{a}}$. Luciana Bongiovani Martins Schenk do Instituto de Arquitetura e Urbanismo da Universidade de São Paulo (IAU-USP), o workshop teve como base uma metodologia (SCHENK; MEDEIROS, 2016) aplicada nas disciplinas de Paisagismo do curso de Arquitetura e Urbanismo do IAU-USP.

Convocando autores que trabalharam o planejamento da paisagem elegendo a bacia hidrográfica como unidade - desde questões teóricas e análise das políticas públicas de implantação (GORSKI, 2010), passando por metodologias pioneiras, desenvolvidas e aplicadas em pesquisas na universidade que extrapolaram a extensão e tornaram-se projeto concretizado (MCHARG, 1969) a estratégia trabalha a partir de camadas de informações. Essa disposição de articular autores e atualizar condutas tem como perspectiva a conquista de projetos visualizados como necessários pela expertise do campo disciplinar, bem como a partir de ações 
populares e grupos de moradores, contando com o intermédio da universidade e tendo como horizonte formular cenários alternativos de desenvolvimento e ocupação, auxiliando na construção de políticas públicas de projeto e ações com a paisagem (HOUGH, 1998). A disciplina desenvolve um método de leitura e intepretação do território, cartografação das problemáticas e indicativo das potencialidades para o território eleito como objeto de planejamento e projeto. Como produto final, os grupos de alunos projetam um sistema de espaços livres que incluem ruas, praças e parques.

Considerando os processos ecossistêmicos e a relação da geografia física com os processos de ocupação do território (SCHUTZER, 2012), que revelam problemáticas - (SPIRN, 1995) e (GORSKI, 2010), as quais foram abordadas no decorrer deste trabalho -, a unidade de paisagem "Bacia Hidrográfica" aparece como uma alternativa que pode agenciar plano e projetos: pode-se trabalhar diferentes escalas dentro de uma mesma bacia, ao passo que, cada bacia, por participar de outras - considerando a realidade de uma cidade, por exemplo - apresenta também suas diferentes escalas.

Assim, ao tomar como referência a bacia hidrográfica entendendo-a como unidade de paisagem,

[...] pretende-se gerar a possibilidade de reconhecer, conceber e desenvolver um Sistema de Espaços Livres articulado a uma leitura territorial, de modo a constituir um conjunto de intervenções atento às especificidades do lugar e em consonância com a cidade da qual participa (SCHENK; MEDEIROS, 2016, p. 9, grifo nosso)

Ao trabalhar a referida unidade de paisagem, um fator que não é alterado - e que nos interessa - é que qualquer ação projetual dentro de uma bacia apresenta impacto sobre todo um território - local ou regional, rural ou urbano -, sua população e paisagem. Assim, toda a ação opera sistemicamente na constituição de espaços qualificados que tenham suas questões infraestruturais contempladas de modo a gerar a vida e alicerçar a dimensão sócio cultural desses lugares.

Um sistema de biovaletas em uma região nas áreas a montante, por exemplo, é suficiente para aumentar a permeabilidade do solo e reduzir o volume de águas que chega aos fundos de vale e corre em direção à jusante dos cursos d'água. Ou ainda, ruas arborizadas que, além de propiciar passeios e deslocamentos sombreados, contribuem para o controle das temperaturas e ilhas de calor, além de armazenar água das chuvas em grande volume no processo de evapotranspiração das árvores. Assim, pode-se partir de pequenas ações, como indicativos de áreas para aplicação de 
infraestruturas verdes, como também desenvolver projetos de praças, parques e ruas completa. Do seu jeito, cada uma das ações, em conjunto ou isoladas, apresenta impacto sobre o todo.

Nas palavras de Spirn (1995):

[...] a integração de toda a área livre urbana num plano unificado promete estender o tradicionalmente aceito valor estético e recreacional dos espaços livres a um papel crucial na saúde, segurança e bem-estar. (SPIRN, 1995, p. 287)

A bacia hidrográfica é tanto uma unidade ambiental quanto uma unidade de paisagem (SCHENK; MEDEIROS, 2016, p. 2). Essa unidade de paisagem, compreendida como rede é composta de nascentes, filetes de água, córregos, riachos e rios - em uma analogia a um sistema circulatório sanguíneo na biologia -, sua natureza pode, através dos espaços livres acima, ocupar e preencher diferentes partes das cidades, melhorando a qualidade ambiental de todo um território quando trabalhado sistemicamente.

Assim, no decorrer da disciplina na qual a metodologia é aplicada, as atividades iniciam-se com uma leitura da cidade - neste caso, São Carlos - SP - e seu território como um todo, tendo como base a legislação e mapas disponíveis, para que sejam produzidas as diferentes cartografias características do campo disciplinar - redes hídricas e viárias, áreas verdes, declividade, entre outros. Ao final da etapa, o cruzamento destas informações faz emergir, em uma cartografia crítica (SCHENK; MEDEIROS, 2016), os conflitos e problemáticas.

No prosseguimento da metodologia desenvolvida pelos autores, parte-se a campo: além da análise longitudinal dos fundos de vale e seus cursos d'água, os alunos trabalham percursos a pé, a partir de "faixas", explorando transversalmente o território da bacia, de cumeada a cumeada atravessando o vale, entendendo as vertentes, o caminho das águas urbanas antes de chegarem aos rios, procurando também compreender a paisagem e realidade de vida da população naquele espaço e tempo e as problemáticas advindas de um método de ocupação que conflita com o meio físico e natural.

Inicialmente, o percurso é planejado tomando por base as cartografias existentes e produzidas pelas equipes, a partir das quais se delineia uma visita de campo aos espaços livres mapeados. Contudo, subentende-se que o percurso irá incitar desvios e suscitar ajustes e mudanças de rota: o palmilhar do território torna-se capaz de redesenhar o plano do passeio original. (SCHENK; MEDEIROS, 2016, p. 5, grifo nosso). 
A partir de então, os discentes produzem novas cartografias, uma considerando fatores como renda, densidade, usos e ocupação, equipamentos públicos, e outra, apresentando os cursos d'água e espaços livres. Em uma nova etapa, a partir de visitas a campo e a projetos que são referência, os alunos partem à escolha de uma área dentro da bacia hidrográfica para o desenvolvimento de exercícios de proposição de um sistema de espaços livres, dos quais devem apresentar como produto final os detalhamentos para um parque dentro desse sistema.

A disciplina original é fornecida durante um semestre letivo do quarto ano da graduação no IAU-USP; portanto, sofreu reformulações na metodologia ao ser desenvolvido durante três dias em Presidente Prudente: o workshop funcionou como uma oficina experimental de projeto com a paisagem. O objetivo foi, sobretudo, contribuir com a formação profissional e crítica dos atuais estudantes, levando-os a pensar possibilidades para um território urbanizado e que se apresenta ocupado e construído: os locais de projeto não são apenas áreas livres ou áreas verdes constantes nos mapas; ao contrário, pretende-se justamente projetar com a paisagem dos espaços livres que emergem a partir das leituras do território e das cartografias críticas produzidas. O cruzamento das informações nas cartografias críticas faz-se necessário pois:

As muitas conexões entre o ar, o solo, a água e a vida são difíceis de ser compreendidas mesmo nos ecossistemas não-alterados. A complexidade do ecossistema urbano é desconcertante e, paralelo ao ecossistema natural, há o ecossistema social, que é dirigido pelos processos econômicos, políticos e culturais. Este sistema social exibe as mesmas inter-relações que caracterizam o sistema natural. Não basta compreender os processos do sistema social ou os processos do sistema natural isoladamente. Ambos moldam o ambiente físico da cidade, que forma o terreno comum entre eles. (SPIRN, 1995, p. 263, grifo nosso)

Para que pudesse ser desenvolvido em um formato de curta duração, dividiuse o workshop em três etapas:

$1^{a}$ - revisão histórica das questões de planejamento urbano e de planejamento da paisagem - relacionadas às questões abordadas nos capítulos primeiro e segundo deste trabalho;

$2^{\text {a }}$ - revisão sobre a formação histórica de Presidente Prudente e os processos de planejamento que nos apresentam às problemáticas atuais 
encontradas em diversas cidades brasileiras - questões abordadas, respectivamente, nos capítulos terceiro e primeiro deste trabalho; e, por fim, $3^{\underline{a}}$ - ida a campo segundo orientações das estratégias em tela

4a - síntese das questões e proposições: ação projetual, apresentando potencialidades e projetando (com) a paisagem a partir do que emerge na leitura do atual estado da arte.

\subsection{Cronograma}

Workshop - 1ำ dia - 16 de maio de 2019

\section{Manhã}

Palestra: $O$ histórico do Planejamento com a Paisagem (figura 80), por Luciana Schenk.

Palestra: O Planejamento e a Paisagem no Brasil - Bacias hidrográficas como unidade de planejamento: contatos entre Estados Unidos e Brasil, CIBPU, CPEU, Planos Diretores e Planos Diretores pós Estatuto da Cidade: a pauta ambiental, por Luciana Schenk.

Figura 80- Palestra “O histórico do Planejamento com a Paisagem”, por Luciana Schenk.

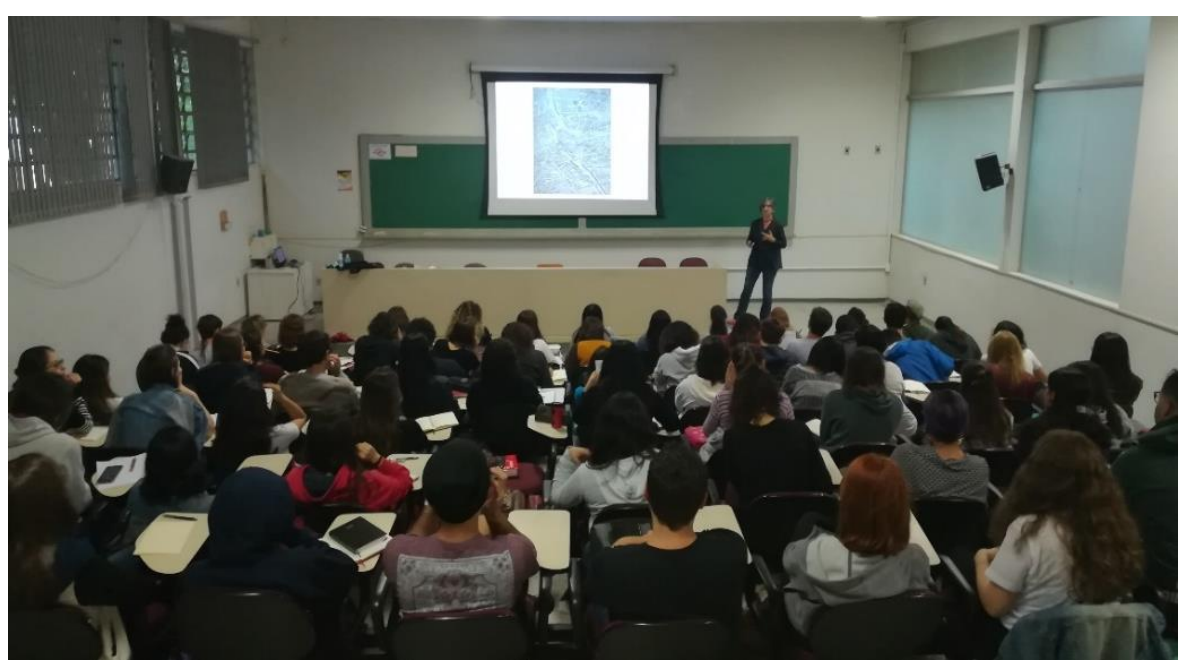

Fonte: arquivo do autor, 2019.

\section{Tarde}

Desenvolvimento de uma dinâmica-aula (figura 81): 
"Presidente Prudente: Um histórico de conflito entre meio físico e desenvolvimento: um parque e uma nova centralidade na década de 80: a construção de uma alternativa? " e "O Plano Diretor de Presidente Prudente 2008: questões ambientais. Cartografia, representação e realidade: Presidente Prudente e as bases oficiais", por Luciana Schenk, Arlete Francisco e Gabriel Francisqueti.

Figura 81 - Dinâmica-aula com as docentes Luciana Schenk e Arlete Francisco.

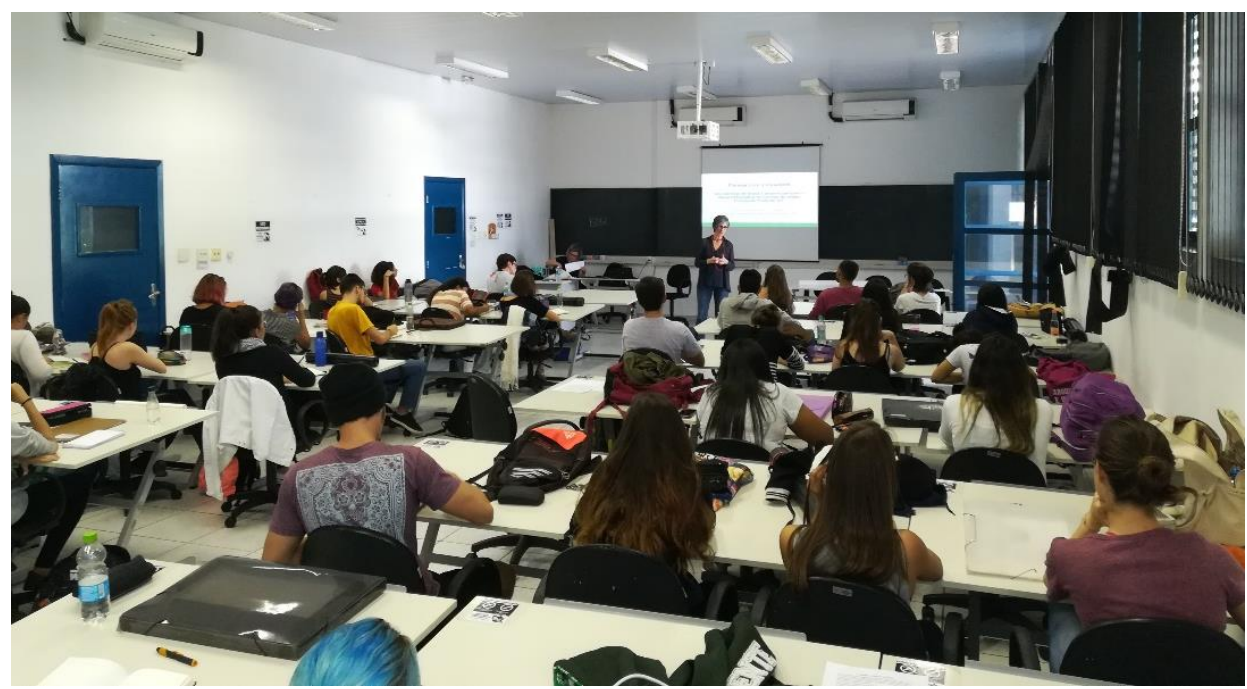

Fonte: arquivo do autor, 2019.

E posterior proposição de recorte de leitura e ação projetual: a Bacia do Córrego do Veado palmilhada de cumeada a cumeada (figura 82), passando pelo vale: a secção de Vale e o percurso planejado em contraposição ao percurso sensível: efetivado. Assim, houve a divisão dos alunos nos grupos de trabalho e "fatias": dez grupos no total, sendo quatro grupos com quatro alunos e seis grupos com três alunos, totalizando trinta e quatro alunos. 
Figura 82 - Cada grupo recebeu um mapa da cidade de Presidente Prudente com os trechos ou "fatias" (1 a 10) a serem palmilhadas de cumeada a cumeada, atravessando o vale.

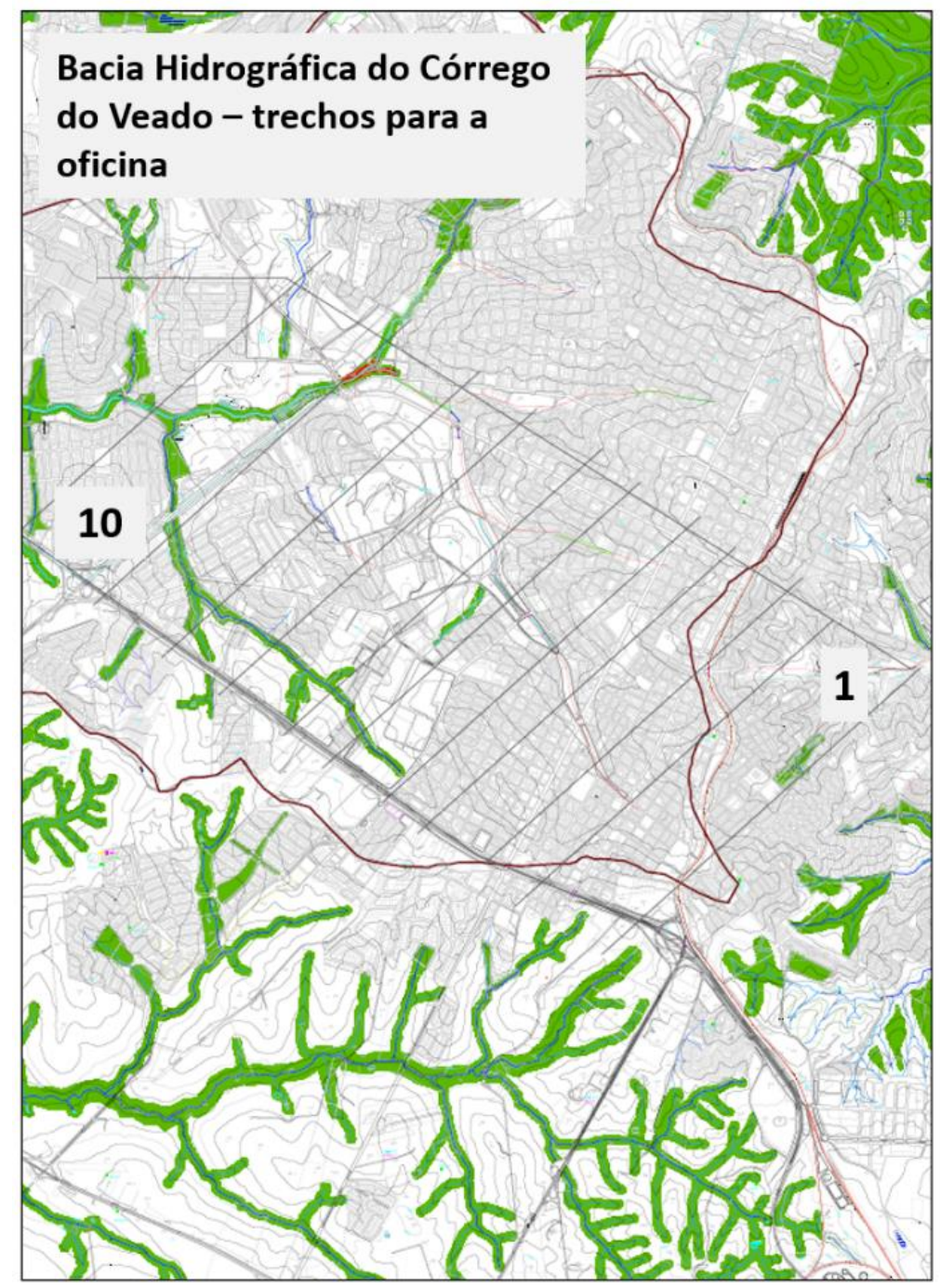

Fonte: Prefeitura Municipal de Presidente Prudente, modificado pelo autor.

Workshop - 2º dia - 17 de maio de 2019

\section{Manhã}

Período de trabalho de campo, no qual cada grupo se dirigiu a sua área para palmilhar a bacia.

\section{Tarde}

Seminário O Córrego do Veado e suas vertentes: uma primeira leitura, no qual cada grupo apresentou as informações e experiências de seu campo (figura 83).

Ao final, foi realizada uma dinâmica que associou todos os trechos em nova cartografia: essa ação reuniu experiências, tornando possível pensar as possibilidades e questões a partir da união. 
Figura 83 - Apresentação dos campos realizados pelos grupos e dinâmica sobre o pensamento em totalidade para a Bacia a partir das cartografias produzidas.
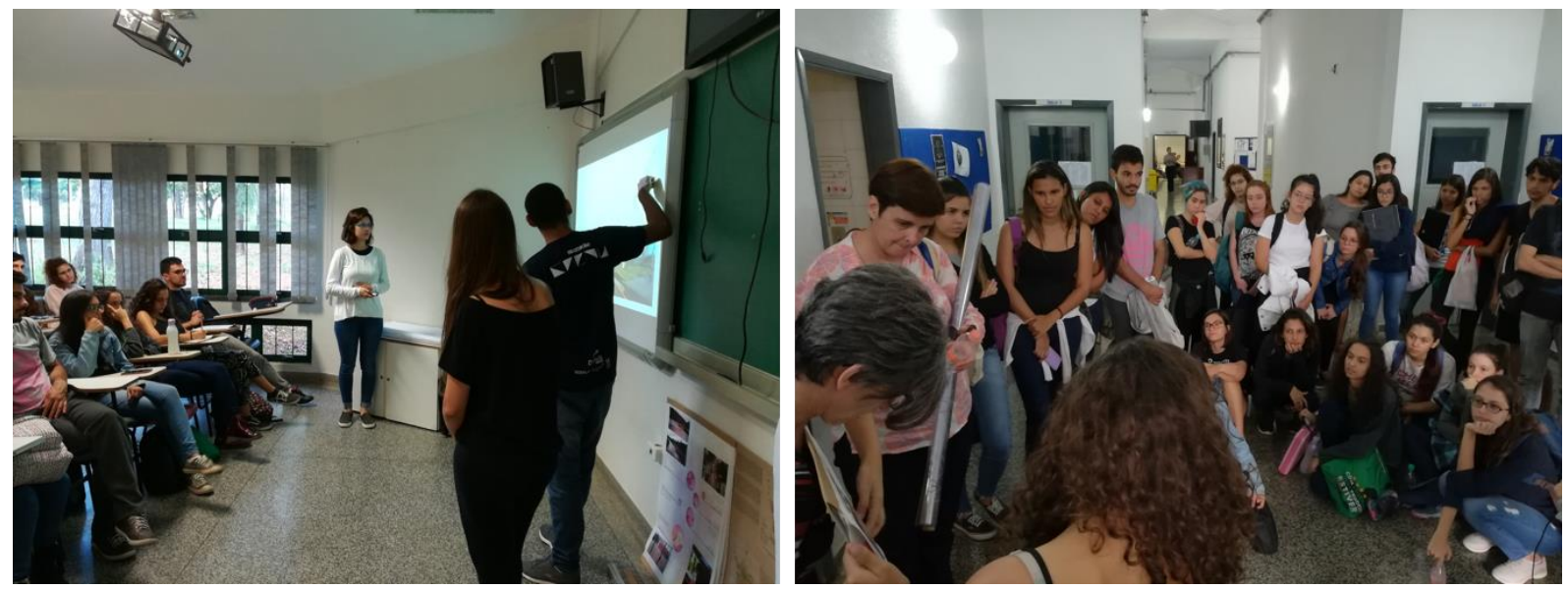

Fonte: arquivo do autor, 2019.

Workshop - 3o dia - 18 de maio de 2019

\section{Manhã - formação de repertório}

Palestra: SEL, sistema de espaços livres, uma proposição contemporânea para a realidade brasileira nas cidades médias: o exemplo de São Carlos-SP, por Luciana Schenk.

\section{Tarde}

Realização da última dinâmica (figura 84): proposta de um exercício prático e coletivo de construção de uma cartografia de intenções para a Bacia do Córrego do Veado.

Os grupos formulam projetos possíveis para a bacia, endereçando soluções que contemplem um sistema de espaços livres em suas dimensões infraestruturais e socioculturais. 
Figura 84 - Dinâmica de apresentação das propostas e intenções de projeto para a Bacia Hidrográfica do Córrego do Veado.
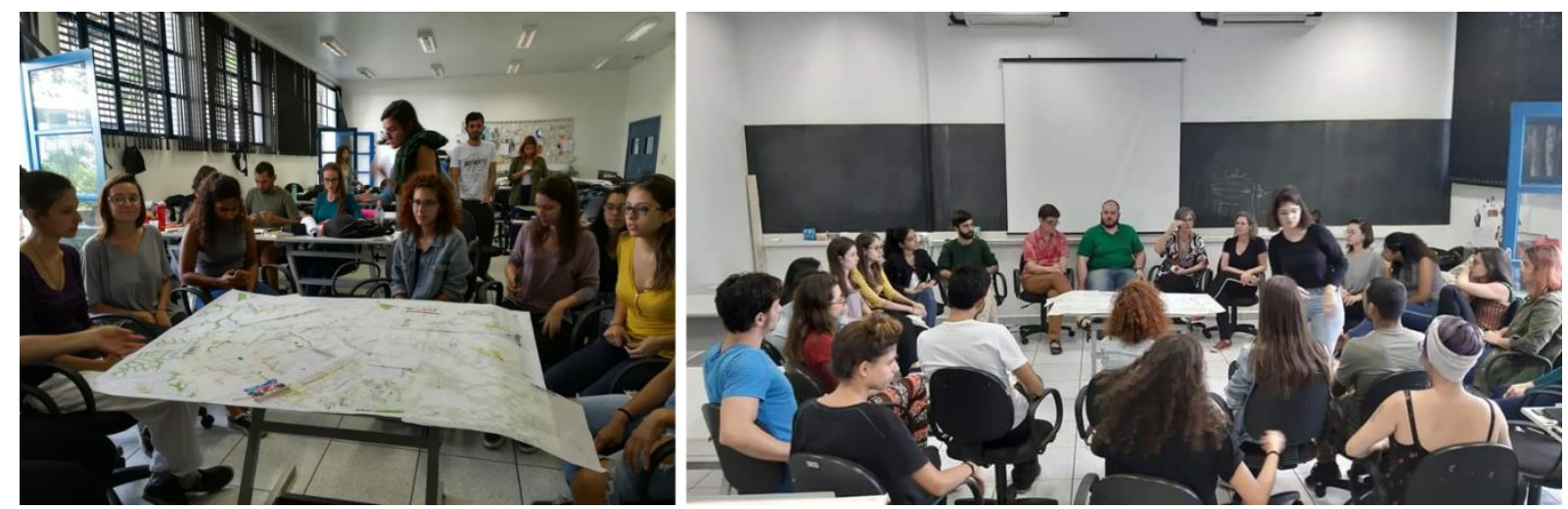

Fonte: arquivo do autor, 2019.

\subsection{Percursos e experiências: estratégia metodológica}

A partir das discussões, teorias e projetos apresentados nas palestras e dinâmicas-aula, os alunos saíram a campo, cada grupo palmilhando sua "fatia" da Bacia; ao final, foi solicitado que cada grupo apresentasse em um seminário suas conclusões e experiências. Foi solicitado que antes de irem a campo, os alunos fizessem um plano de como dar-se ia o percurso, podendo o mesmo ser alterado desde que a alteração fosse documentada - interessava perceber a alteração entre aquilo que depreendemos das cartografias e o que a realidade nos desperta como gatilho de atenção. Foi também sugerida a levada de material para registro, seja fotográfico, seja desenho, de forma que o percurso pudesse ser comentado através das imagens produzidas.

Todos os grupos apresentaram alterações nos traçados predeterminados "percurso planejado versus percurso sensível" - enfatizando a influência do território e da paisagem na determinação dos caminhos. Além disso, a variação nos percursos propostos (figura 85) evidencia, através das percepções, as diferenças de se projetar a partir de uma visão de sobrevoo e a de se realizar uma radiografia in loco da paisagem para os processos de planejamento e projeto. 
Figura 85 - Percurso planejado versus percurso sensível.

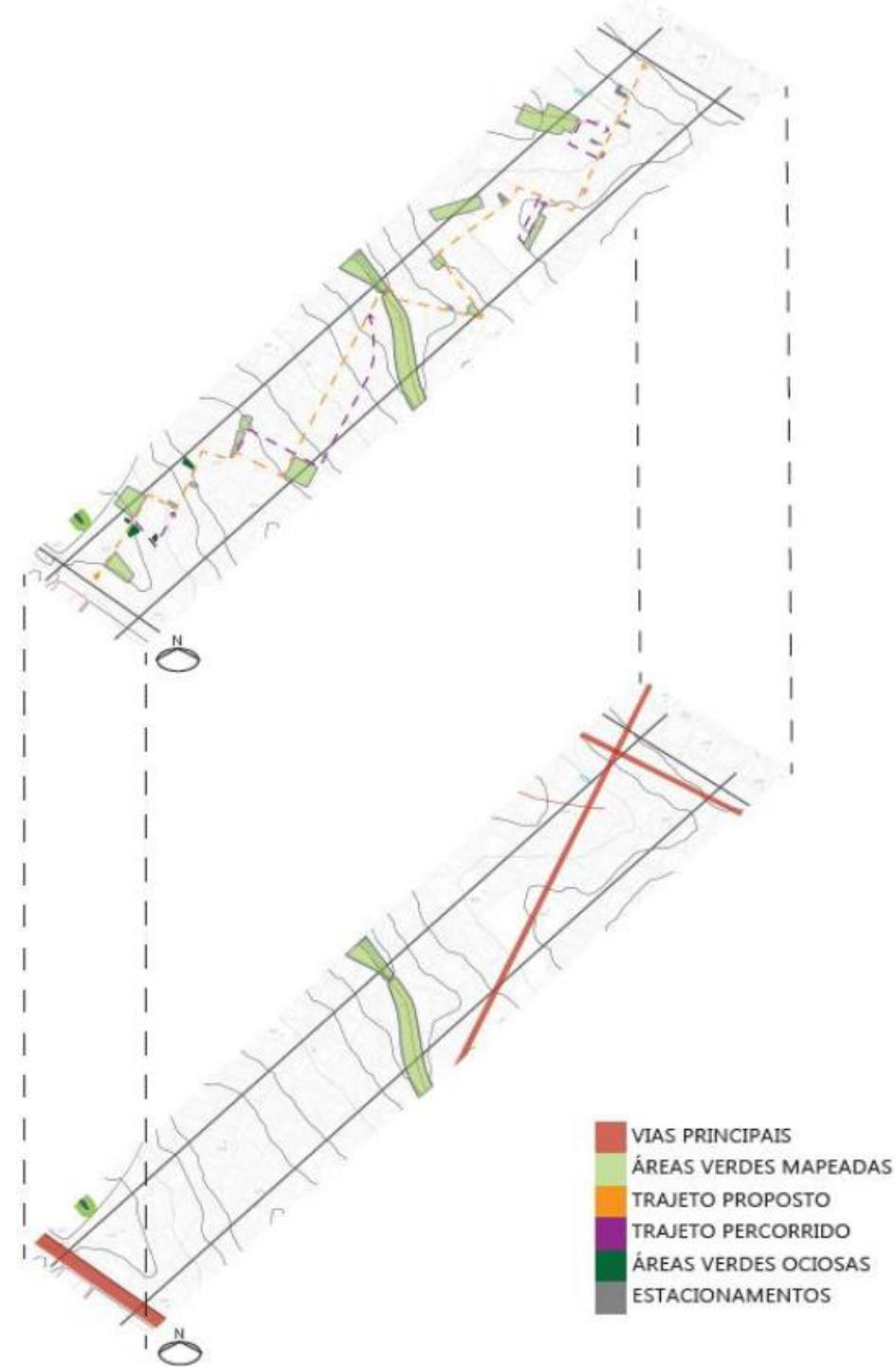

Cartografias: identificação das preexistências e endereçamento de espaços livres que poderiam formar um sistema conectando vias principais e Parque do Povo. Notar o percurso planejado e o percurso sensível. Trecho 4 - Fonte: Antônio Souza, Marina Abreu e Sarah Garrido.

A seguir, exemplos (figuras 86 a 89) retirados das apresentações realizados pelos alunos após a visita a campo, com cada grupo palmilhando sua fatia do território e trazendo à dinâmica suas percepções e inquietações. 
Figura 86 - Percursos e experiências.
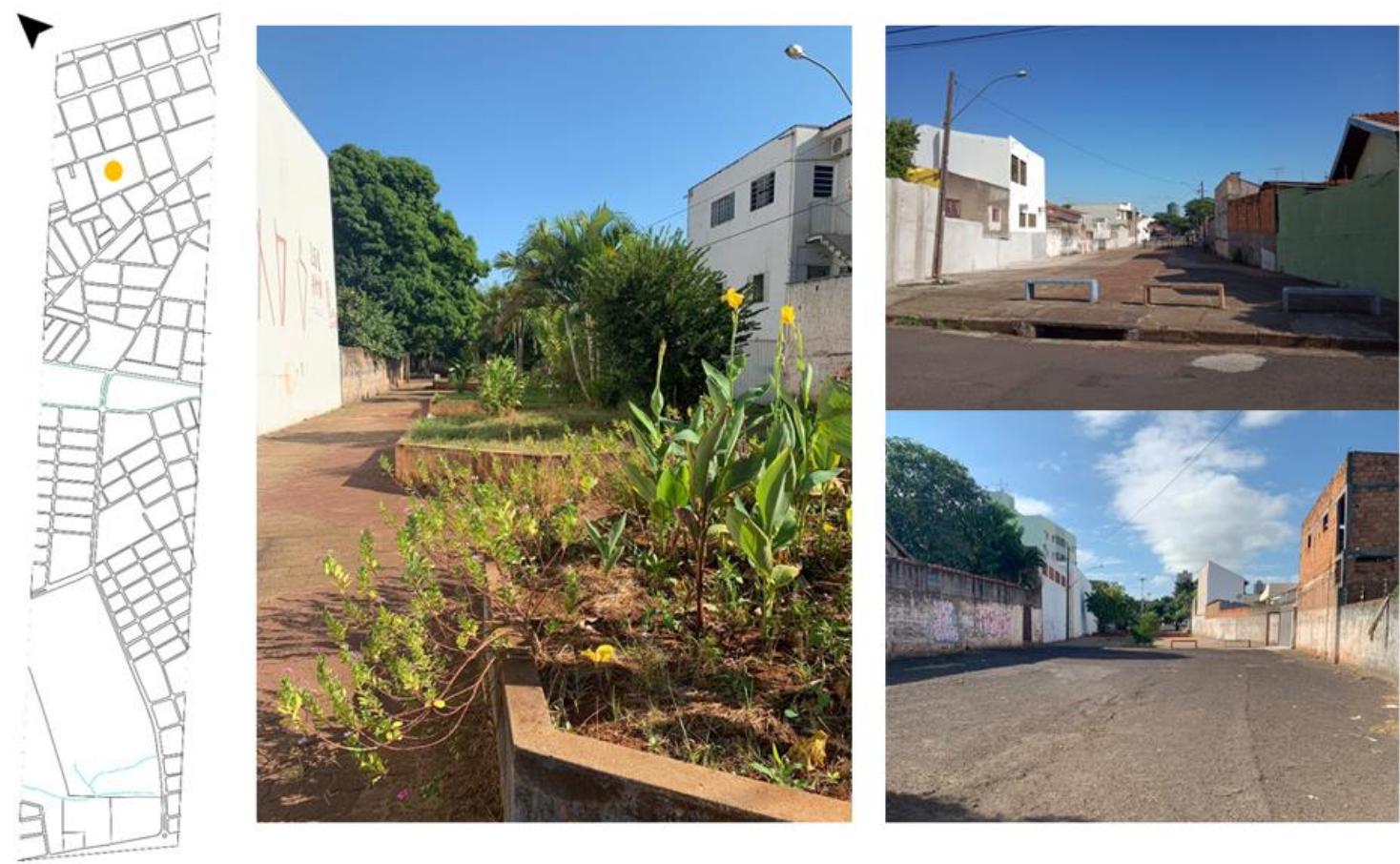

Espaços livres sobre a galeria do Córrego Água Bôscoli. Predominância da "engenharia cinza", fruto do planejamento urbano proposto nos anos 1970. Trecho 5 - Fonte: Ana Luiza Leonardi, Fernanda Rígolo, Luana Dutra.

Figura 87 - Percursos e experiências.
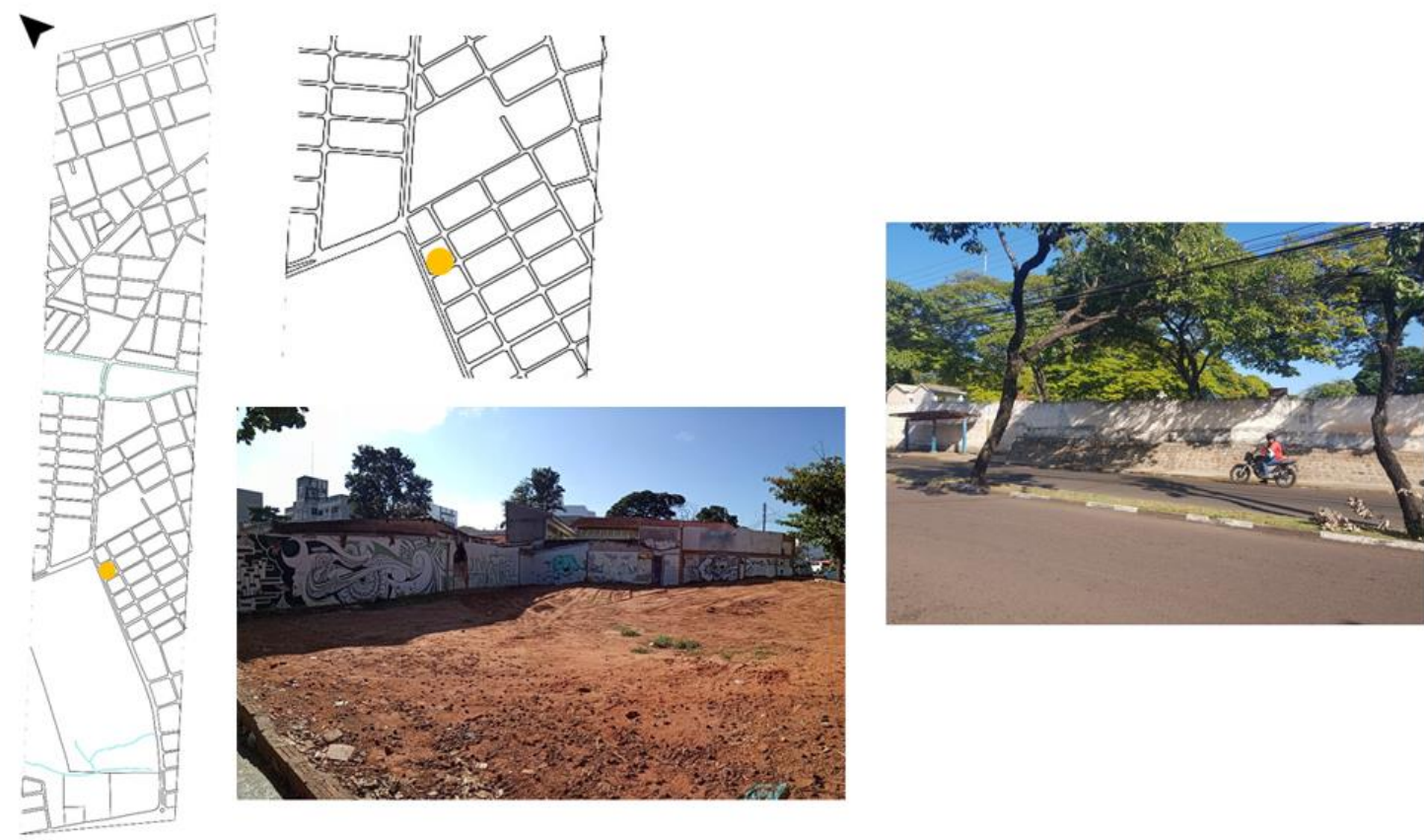

Muros: barreiras físicas e visuais, mas também possibilidades, como arte urbana. Trecho 5 - Fonte: Ana Luiza Leonardi, Fernanda Rígolo, Luana Dutra. 
Figura 88 - Percursos e experiências.
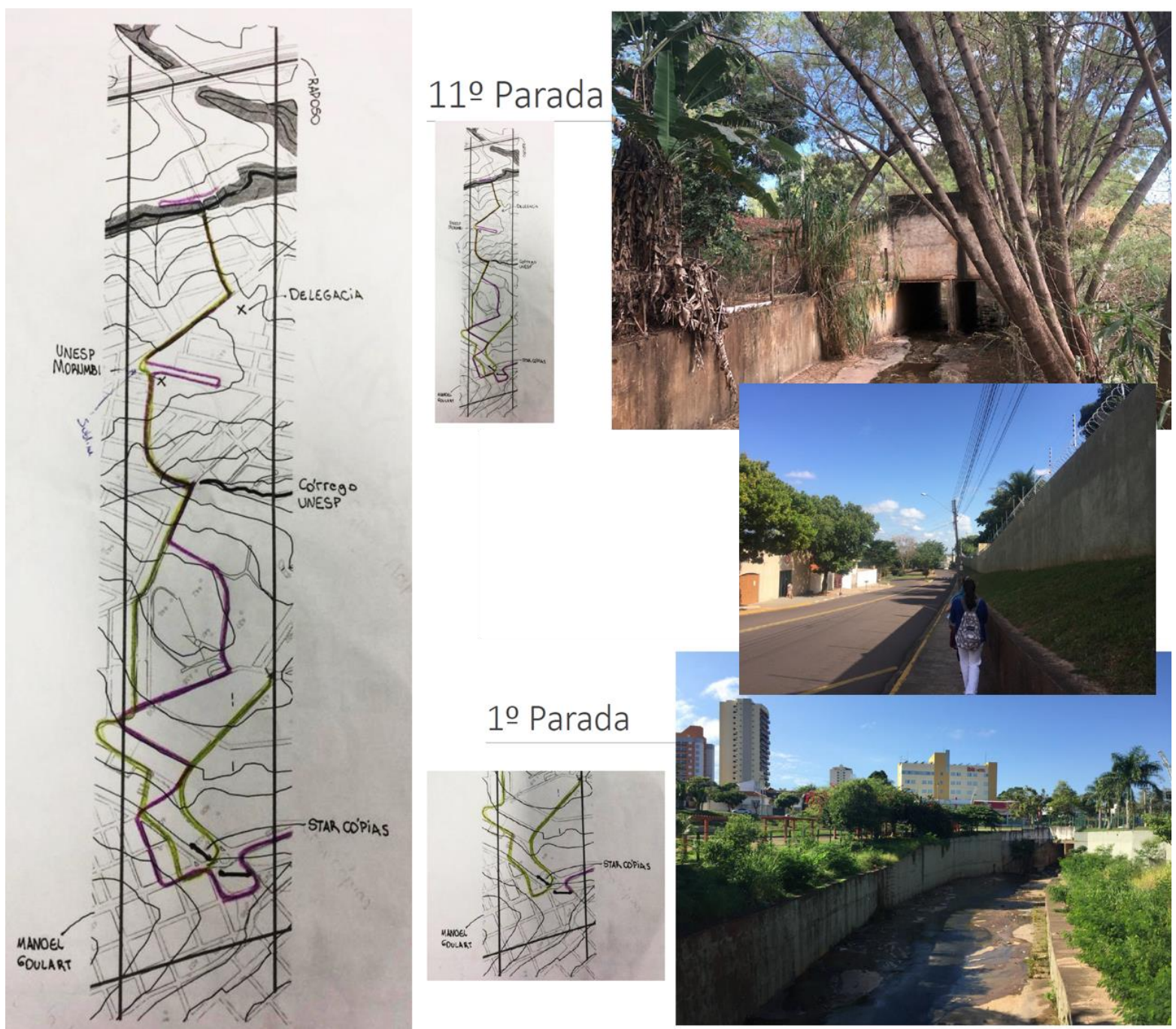

Córregos canalizados e condomínios fechados. A transformação dos cursos d'água em canais de concreto acontece desde a região mais central às regiões mais distantes desta. Trecho 8 - Fonte: Eloisa Lima, Betina Hernandes, Renata Yoshitake. 
Figura 89 - Percursos e experiências.
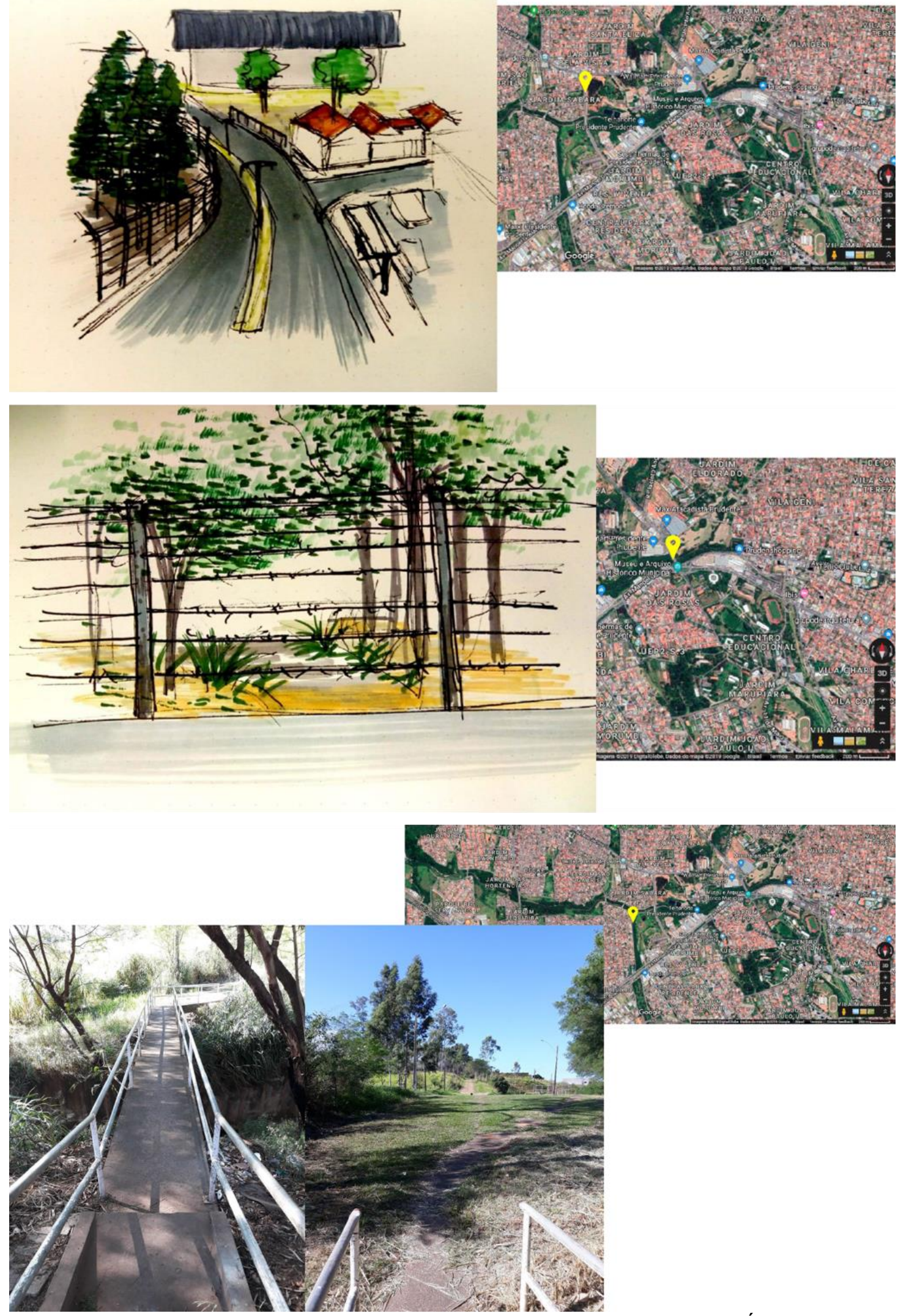

Forma urbana e perspectiva: materialidades, rugosidades, espaços livres; Cercamento das Áreas de Preservação Permanentes; Passarela sobre o Córrego do Saltinho, canalizado. A natureza está na cidade, mas é preciso que seja redescoberta. Trecho 10 - Fonte: André Araújo, Eloah Martins, Gabrielle Alberini, Julia Hirche 


\subsection{Proposições}

A partir das experiências em campo e de uma discussão sobre as cartografias geradas para a Bacia Hidrográfica com a união das "fatias", foram endereçadas, na última dinâmica (figura 90) do workshop, proposições para a região da Bacia Hidrográfica do Córrego do Veado.

Figura 90 - Apresentação e discussão sobre as proposições para um projeto de paisagem pensando sistemicamente.
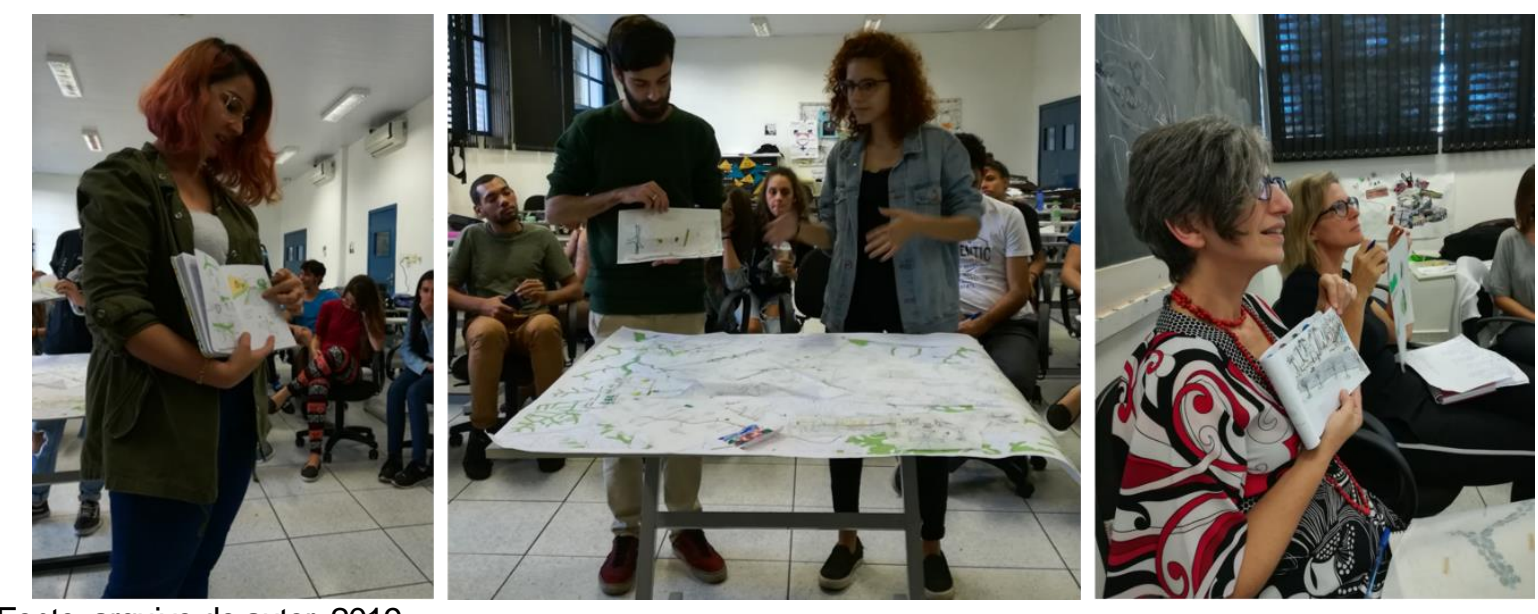

Fonte: arquivo do autor, 2019.

Ao palmilhar o território, adentra-se um planejamento sensorial - que vai desde mapas mentais ( $\mathrm{LYNCH}, 1997)$ e seus elementos, entendo a paisagem através de seus marcos, limites, pontos nodais, vias e bairros, à experiência desses lugares, que são representadas, por exemplo, através das visões seriais (CULLEN, 1983). Procurando entender as dinâmicas da paisagem urbana - compondo um enredo para um método de projeto que, a partir de então, não é apenas fruto de uma visão de sobrevoo - muitas vezes deslocado da realidade, do "chão" -, mas de um contato entre ações, teóricas e práticas. As proposições (figuras 91 a 97) emergem a partir das experimentações e experiências reais dos usuários, com base nas teorias e referenciais de projeto apresentadas anteriormente (MCHARG, 1969; SPIRN, 1995; HOUGH, 1998; GORSKI, 2010; SCHUTZER, 2012) durante as palestras e aulas teóricas.

O intuito é provocar nos alunos e participantes, tanto do workshop quanto da disciplina regular, o entendimento de que a cidade atual e as problemáticas por ela apresentadas são frutos de processos de planejamento e políticas públicas que foram instauradas ao mesmo tempo em que o campo disciplinar da arquitetura da paisagem 
já apresentava outras soluções possíveis e concretas, algumas delas idealizadas no século XIX - como os projetos de Frederick Law Olmsted apresentadas em Spirn (1995) - e século XX - como as metodologias e projetos apresentados em McHarg (1969) e Hough (1998) - e que cotejavam aquilo que veio a ser referenciado como base para um planejamento e projeto sustentáveis: um planejamento urbano e de paisagem ecossistêmicos, dos quais participem os processos naturais e sociais e nos quais a cidade seja entendida como parte da natureza.

As imagens a seguir apresentam parte dos produtos elaborados pelos discentes na última dinâmica do workshop: as proposições para um projeto de paisagem, tendo a Bacia Hidrográfica do Córrego do Veado como base.

Figura 91 - Proposições elaboradas durante o workshop.

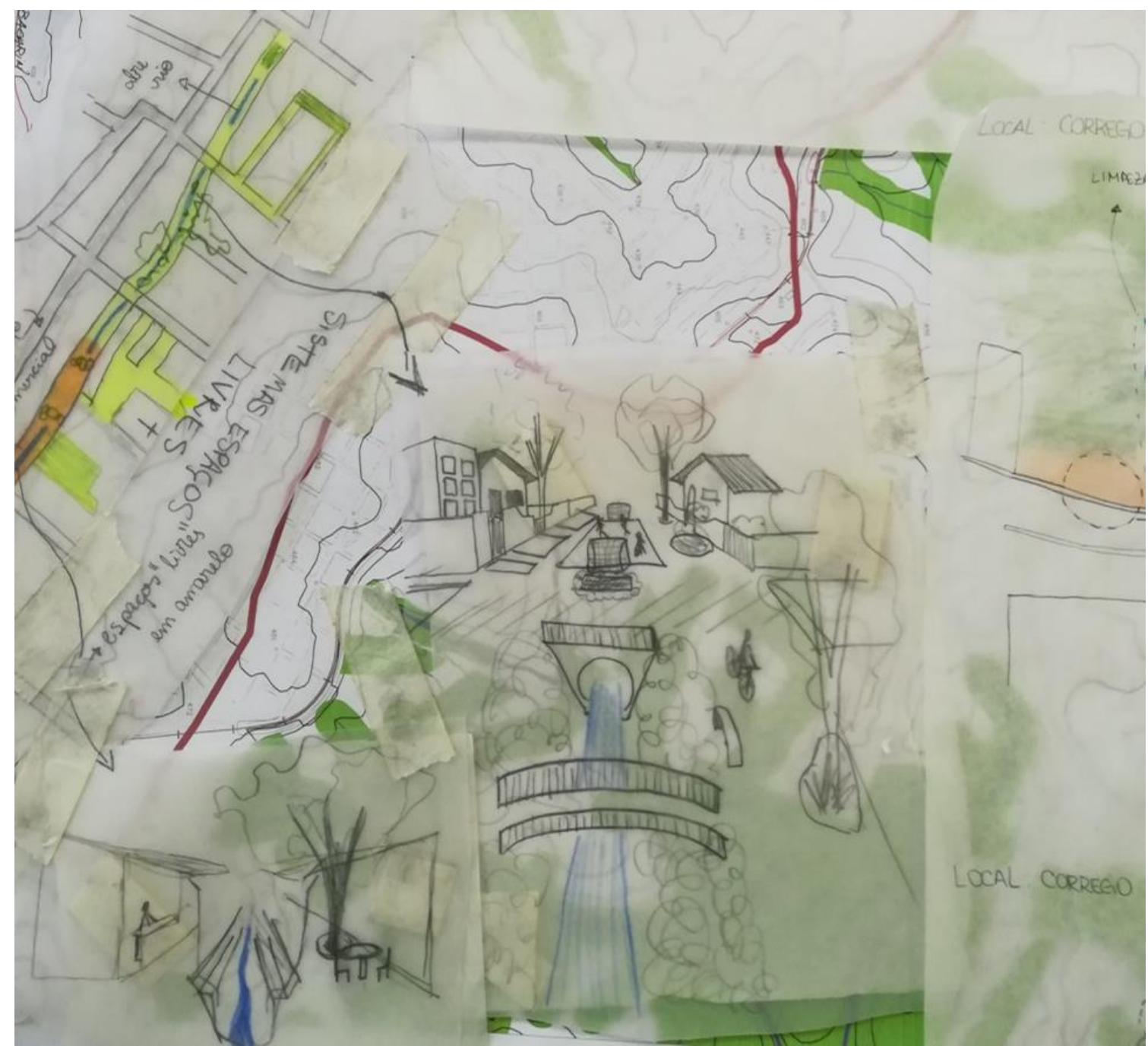

Proposição de abertura de trecho do Córrego Água Bôscoli e construção de equipamentos de lazer, passarelas, área sombreadas e fachadas ativas na rua de pedestres. Fonte: Workshop, 2019. 
Figura 92 - Proposições elaboradas durante o workshop.

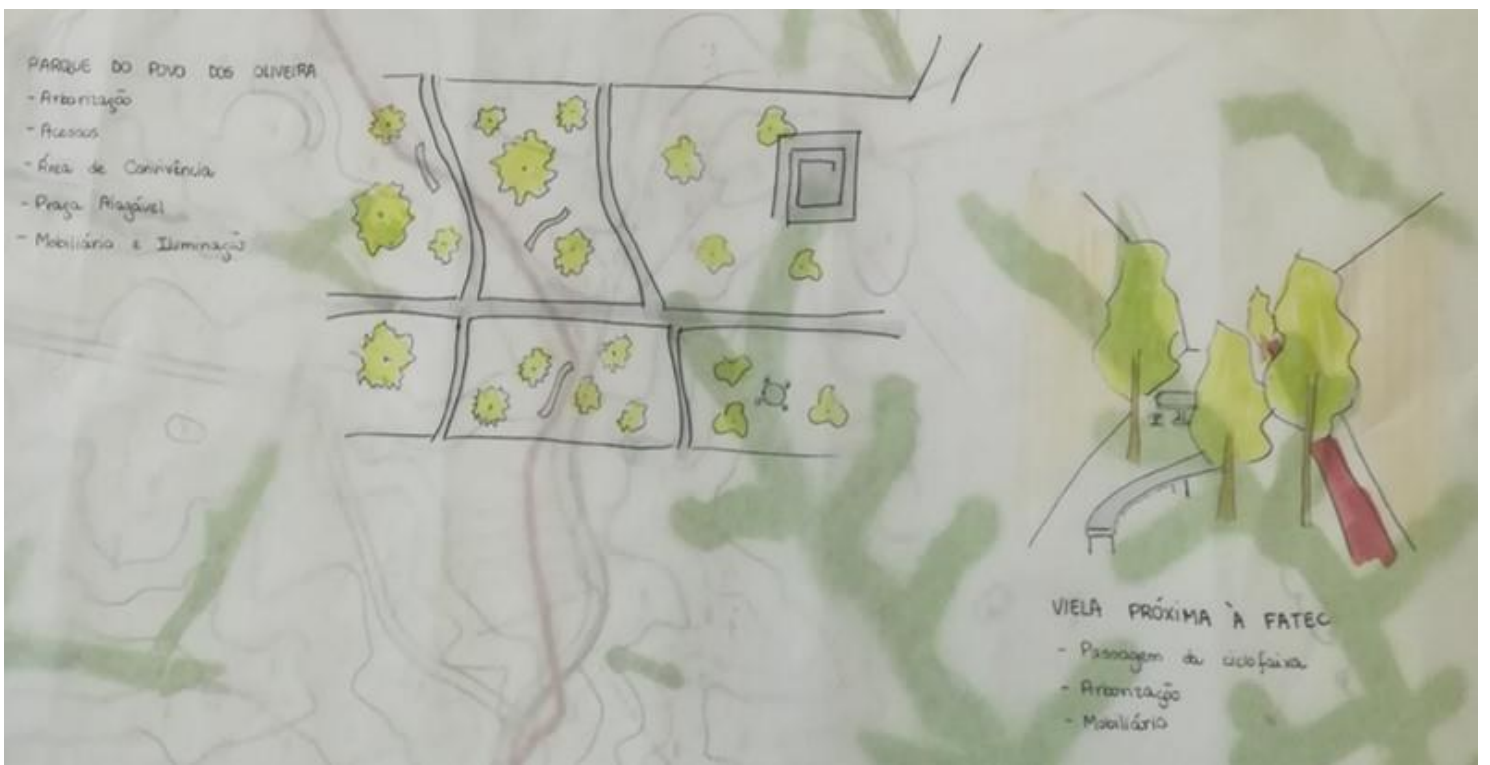

Parque do Povo dos Oliveira (zona Leste de Presidente Prudente): iniciativas de projeto pensando em um sistema que esteja integrado à Bacia Hidrográfica do Córrego do Veado. Proposição de mobiliário e iluminação, dispositivos de infraestrutura verde - praças alagáveis -, arborização, espaços de convivência. Fonte: Workshop, 2019. 
Figura 93 - Proposições elaboradas durante o workshop.

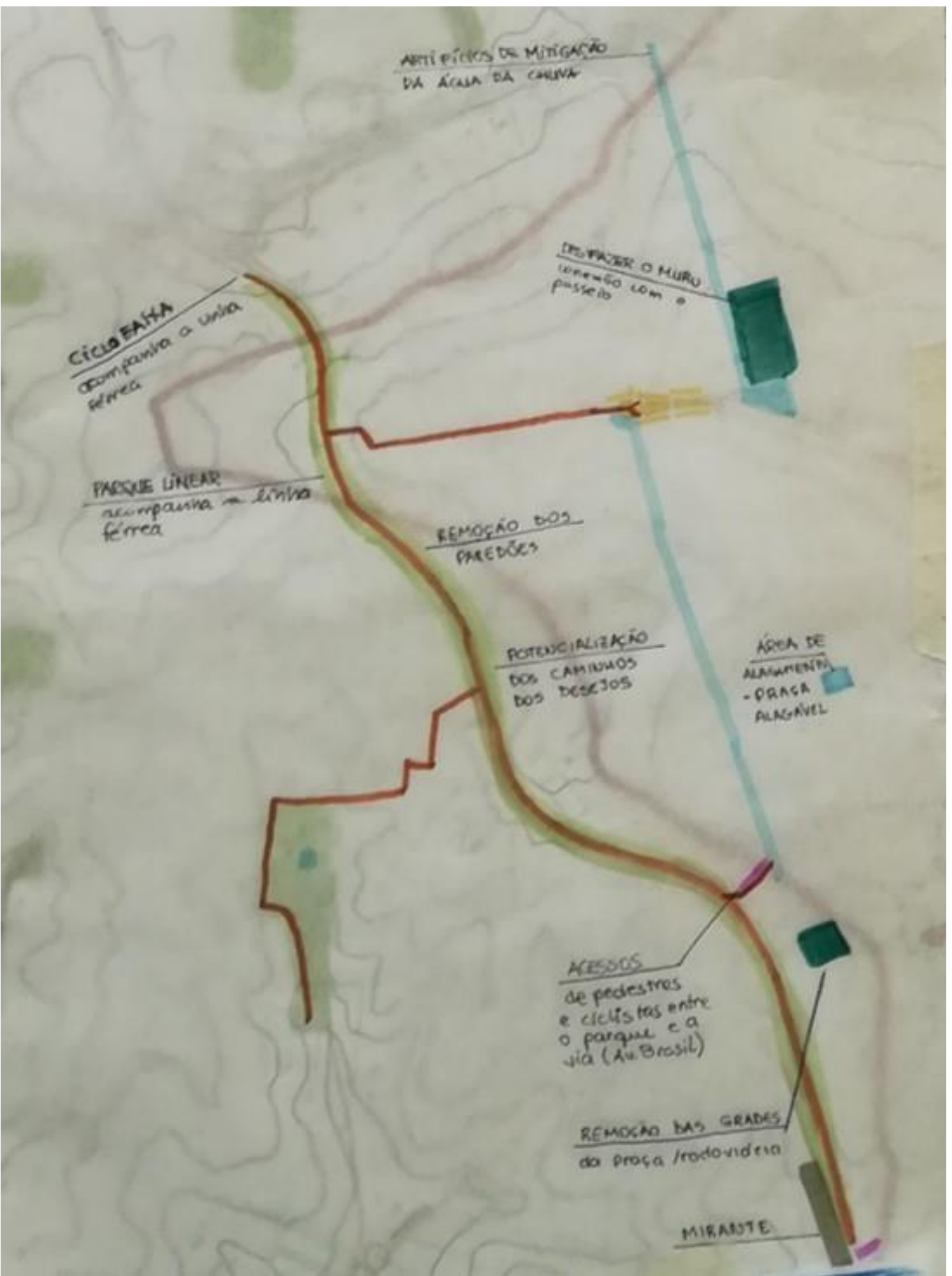

Proposta de um parque linear para a linha férrea - espigão do relevo e divisor das bacias hidrográficas: ciclofaixa acompanhando a linha férrea, remoção dos paredões que dividem a cidade "antes da linha férrea/após a linha férrea", remoção das grades que circundam a Praça da Rodoviária, proposta de um mirante. Fonte: Workshop, 2019. 
Figura 94 - Proposições elaboradas durante o workshop.

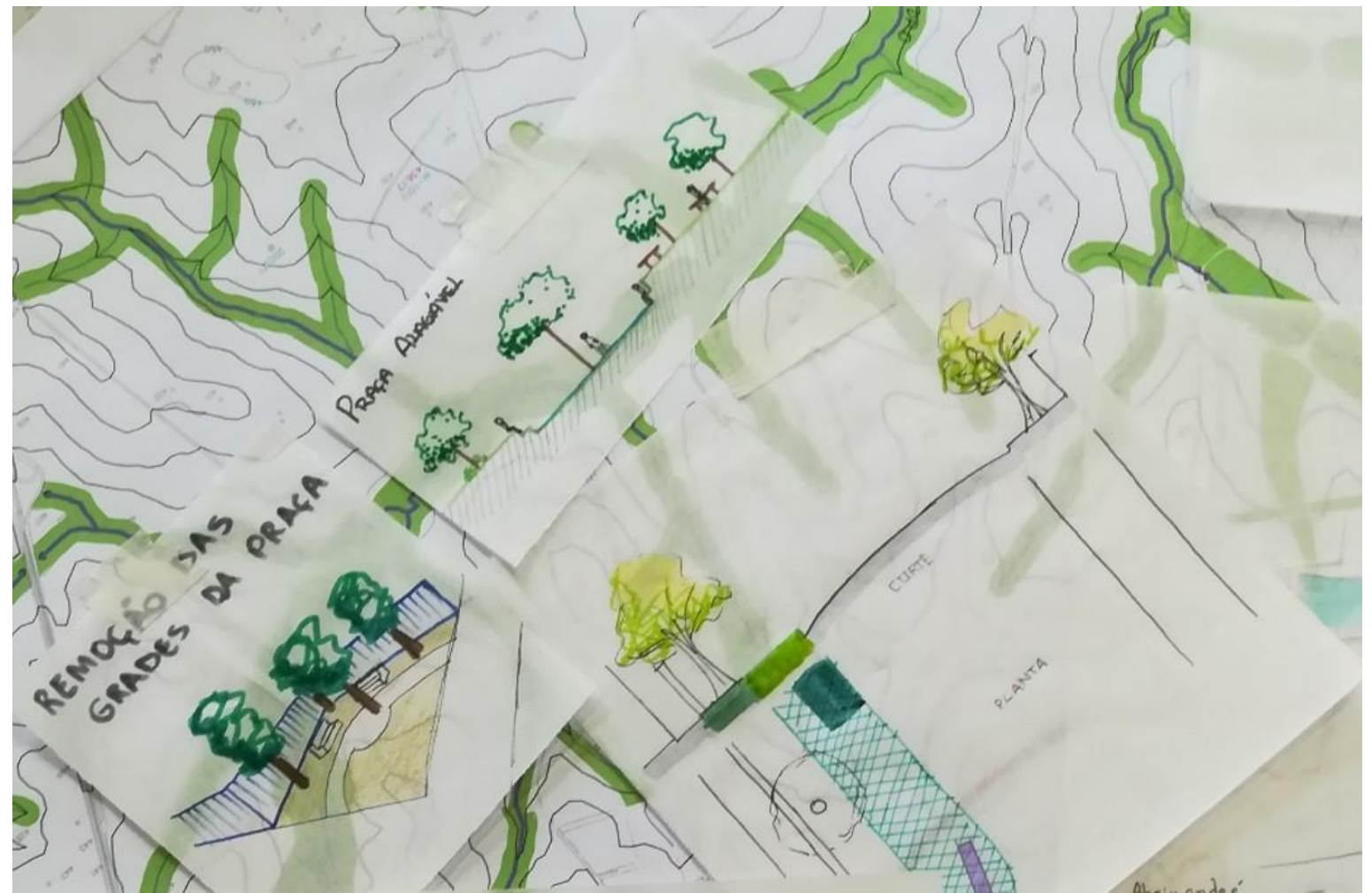

Detalhamento (corte e perspectivas) para o parque linear na região da ferrovia: remoção das grades na Praça da Rodoviária, corte esquemático de uma praça alagável e corte esquemático para uma rua com dispositivos para captação de água (infraestrutura verde). Fonte: Workshop, 2019.

Figura 95 - Proposições elaboradas durante o workshop.

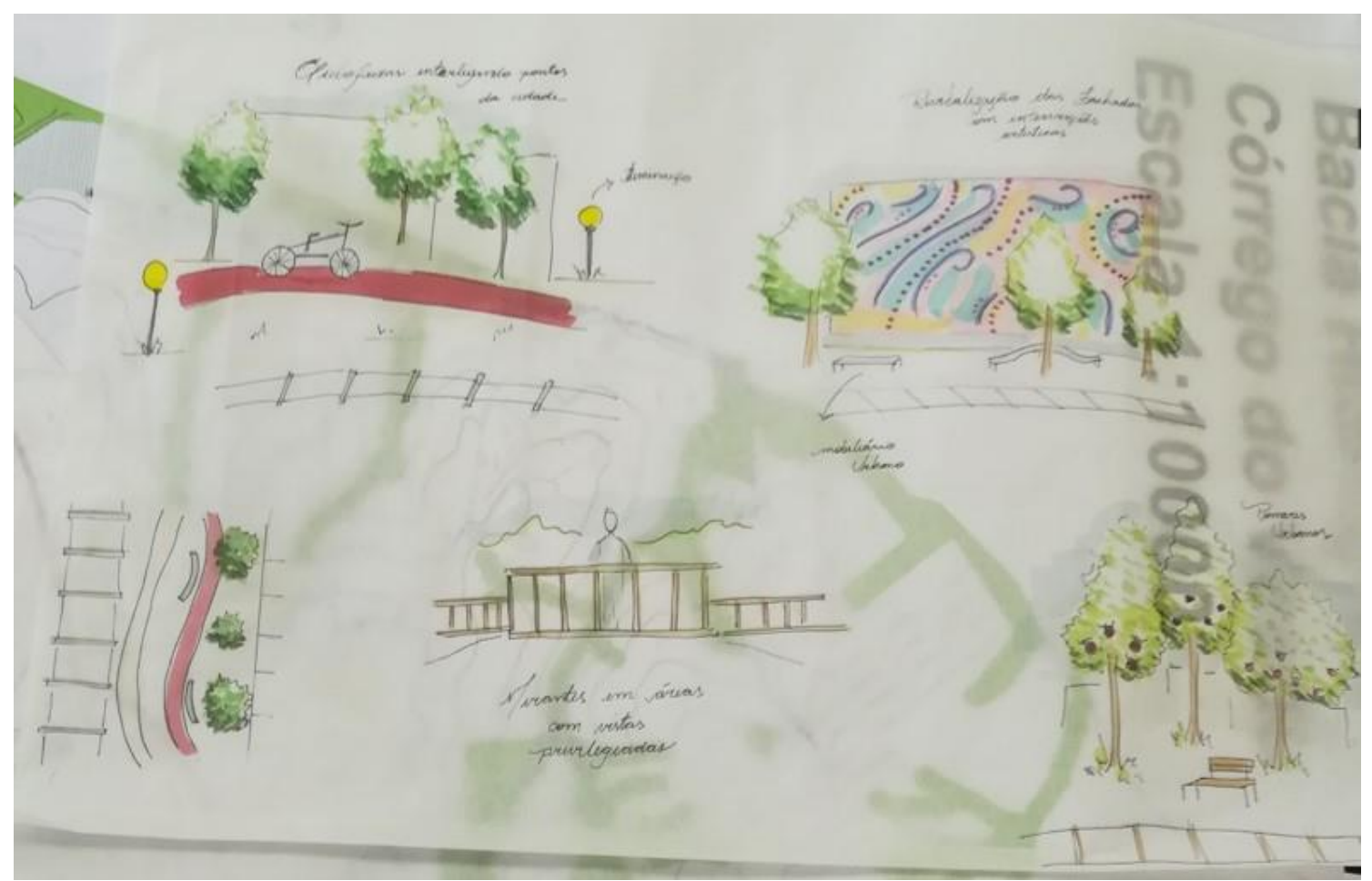

Detalhamento das propostas para o parque linear na linha férrea: ciclofaixa, espaços de permanência, revitalização das fachadas e indicação de arte urbana em paredões/fechadas cegas, mirante em áreas com vistas privilegiadas, pomares urbanos. Fonte: Workshop, 2019. 
Figura 96 - Proposições elaboradas durante o workshop.

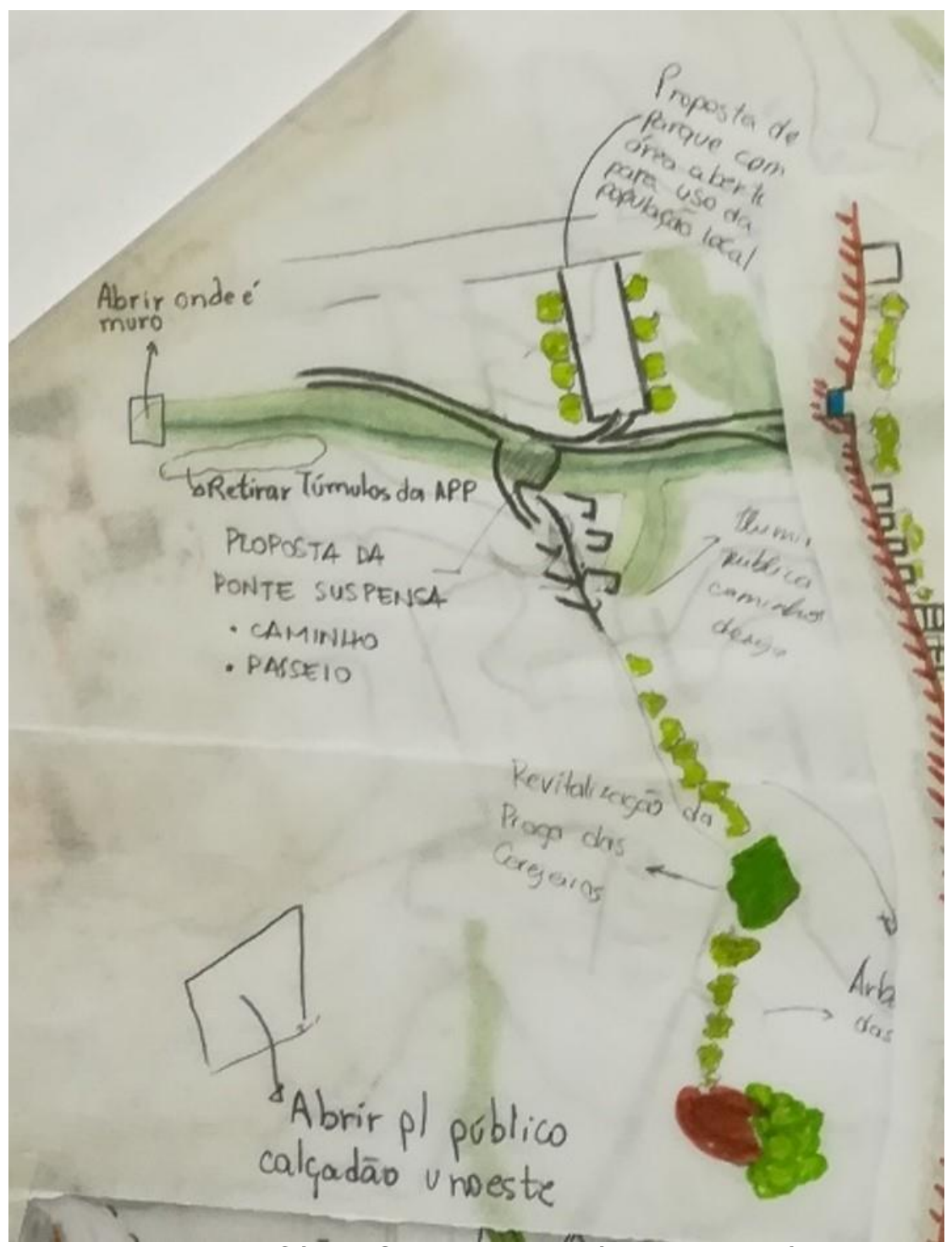

Propostas para a região da nascente do Córrego Saltinho: remover túmulos no cemitério que estão próximos à APP; e abrir o muro entre a avenida da Saudade e a nascente do Córrego do Saltinho - que atualmente impede a vista para o fundo de vale do córrego; proposta de uma ponte suspensa que interligue o parque linear, revitalização da Praças das Cerejeiras e conexão desta com o parque no fundo de vale e promover a abertura do calçadão da Unoeste para o público - atualmente uma rua de pedestre com alguns trechos de uso exclusivo pela universidade. Fonte: Workshop, 2019. 
Figura 97 - Proposições elaboradas durante o workshop.

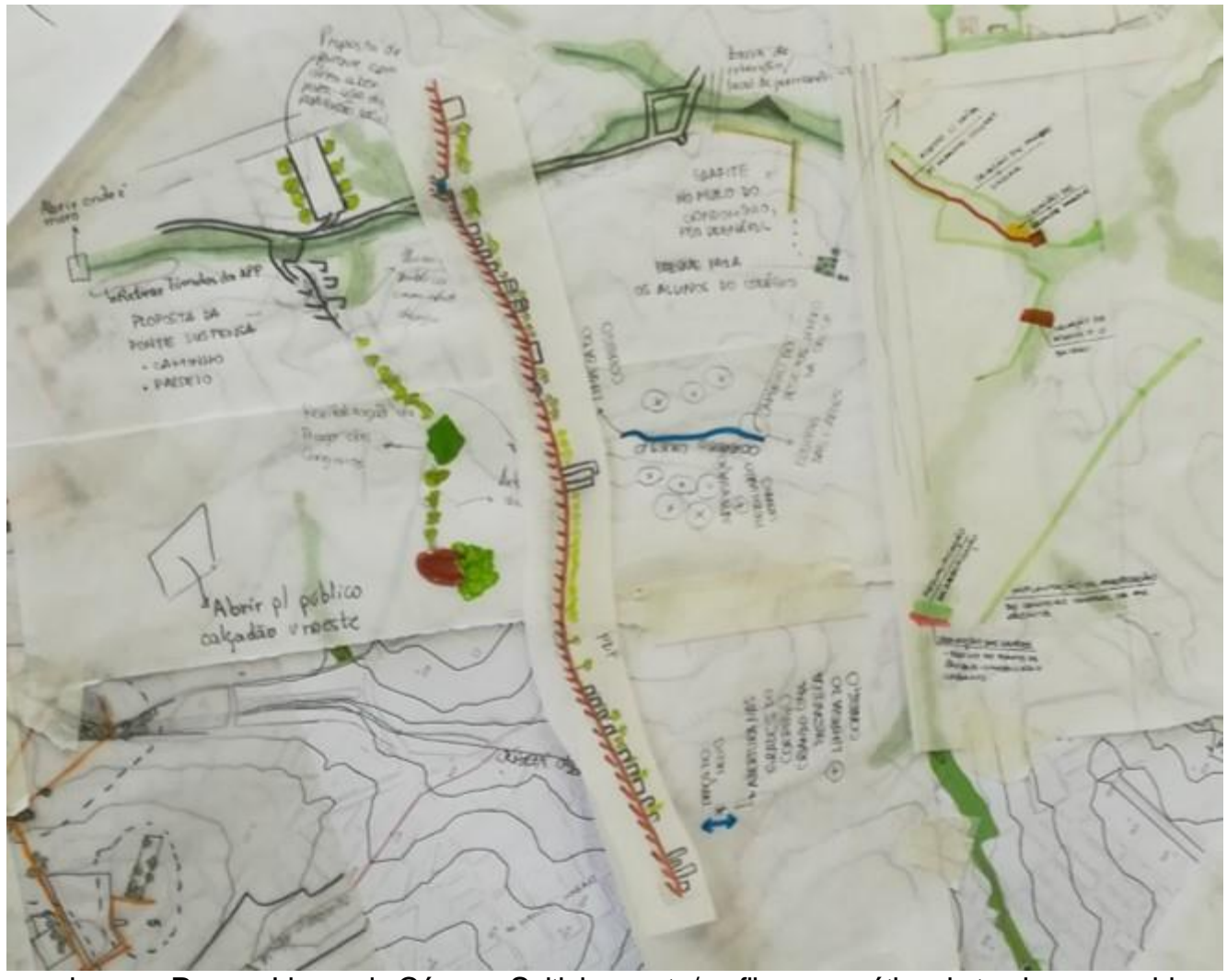

Proposta geral para o Parque Linear do Córrego Saltinho: corte/perfil esquemático do trecho percorrido pelo grupo; proposta de uma bacia de retenção; grafites nos muros dos condomínios fechados e conexão do Córrego Saltinho com o Córrego da UNESP através destes corredores verdes artísticos; limpeza do Córrego da UNESP, remoção das grades e inserção de mobiliário urbano e arborização; e criação de um parque linear - com espaços de permanência e pontes de pedestres - junto ao Córrego do Saltinho até o encontro de suas águas com o Córrego do Veado, formando um sistema de espaços livres. . Fonte: Workshop, 2019.

Ao se trabalhar transversalmente, partindo de uma linha à outra da divisa das bacias hidrográficas - atravessando o vale -, o método projetual ganha fôlego para, em momentos futuros, propor a conexão entre as bacias hidrográficas e seus espaços livres: é uma ação em rede, formando um sistema de espaços livres a partir de diversos outros sistemas menores. Do planejamento local ao regional, da Micro à Macrobacia hidrográfica. Como relata Spirn (1995):

As soluções para os problemas da cidade e de sua região não devem ser isoladas, mas de preferência coordenadas e tratadas com a maior compreensão do ecossistema que for permitida pelo conhecimento atual. (SPIRN, 1995, p. 285, grifo nosso)

Considerando as devidas proporções - de os produtos finais da oficina terem sido produzidos em um único período do último dia - o resultado apresentou-se positivo, especialmente no que diz respeito à compreensão sistêmica do planejamento com a paisagem, elencando ações projetuais que vão desde pequenas ações 
pontuais a parques lineares nos córregos e linha férrea, percorrendo praças e possibilidades de ruas arborizadas, formando um sistema de espaços livres. Enfatizase ainda o alcance da proposta teórica, prática e metodológica preconizada pelos autores da metodologia desenvolvida e pelos autores abordados nesta pesquisa

Uma primeira estratégia poderia ser a de aproximação: da população com a paisagem e a natureza da cidade. Como enfatiza Hough (1998): a de tornar visíveis os processos que sustentam a vida - neste caso, proposição de mirantes em pontos estratégicos e espaços de permanência nos fundos de vale e nos encontros dos cursos fluviais, retirada de muros e grades para melhor conexão visual e atração da população para estes espaços livres.

Tem-se a oportunidade de poder trabalhar sistemicamente com a paisagem, propondo projetos e executando ações que a alterem positivamente e tragam ganhos ao meio ambiente urbano e sua população.

Por mais que boa parte dos rios na Bacia Hidrográfica do Córrego do Veado estejam canalizados e alguns deles tamponados, esta pesquisa e os trabalhos de campo, dos quais fazem parte o workshop, revelam oportunidades de se alterar a situação atual das relações rios e cidade e também entre cidade e natureza; alterando dessa forma também as relações destes com a população.

Como observado nos capítulos anteriores, alguns destes córregos apresentam áreas de proteção permanentes e outros espaços livres contíguos que permitiriam a implantação de diferentes projetos dentro de um sistema. Além disso, o próprio workshop mostra a possibilidade de trabalhar com o ambiente construído nutrindo percepções: instalando mirantes, parques lineares na linha férrea, praças, arborização urbana e dispositivos de infraestrutura verde.

Em relação às árvores da cidade, deve-se ter como estratégia:

[...] explorar o potencial da vegetação para melhorar o clima e a qualidade do ar, a estabilidade das encostas e a qualidade das águas para prevenir as enchentes, aumentar a diversidade da propagação da vida silvestre e melhorar a imagem da cidade. (SPIRN, 1995, p. 224)

Em relação aos parques e espaços livres na região de espigão do relevo como a ferrovia em Presidente Prudente - e o planejamento relacionado à drenagem urbana, questão fundamental nesse trecho da cidade, conforme visto -, Spirn (1995) também sugere que parte de um plano para prevenção de enchentes e conservação e recuperação da água deva: "localizar nas cabeceiras e nas várzeas a jusante novos 
parques e área verdes para preservar a capacidade de armazenamento das águas, e para melhorar a recarga dos lençóis freáticos" (SPIRN, 1995, p. 184).

No caso desenvolvido em Presidente Prudente - SP, o grupo participante do workshop (figura 98) apresenta o indicativo das potencialidades em uma paisagem já consolidada - em termos de materialidade do ambiente construído e ocupação do território, considerando que a bacia do Córrego do Veado está completamente inserida em uma área urbana - mas que anseia por mudanças e precisa delas conforme verificado através do referencial histórico de planejamento para a cidade e os reflexos dessas políticas para a relação rios e cidade e espaços livres.

Esta pesquisa tratou de radiografar a situação de uma cidade contextualizando os processos dentro de uma chave histórica de ações e políticas de planejamento e ocupação do território que nos trazem às dinâmicas e problemáticas atuais - e também de demonstrar as potencialidades existentes para um plano de ações e planejamento dentro de outra chave, de um campo disciplinar que pensa e projeta a paisagem ecossistemicamente - e que o faz desde o final do século XIX.

Se paisagem é a "acumulação de tempos desiguais" (SANTOS, 2002, p.21), qual cidade ou relação natureza e cidade, ou ainda, qual qualidade de paisagem deixaremos para este e os próximos tempos? O trabalho desenvolvido pela pesquisa e também no workshop evidencia algumas possibilidades e muitos caminhos...

Figura 98 - Participantes do workshop.

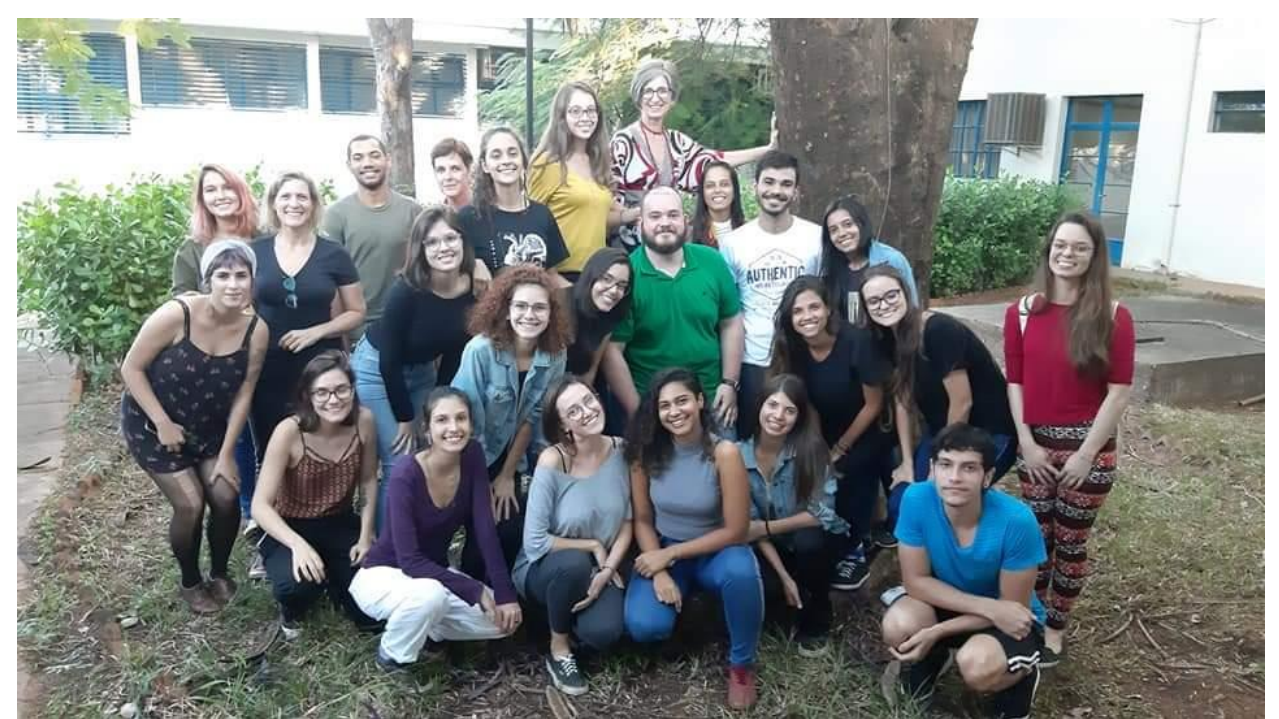

Docentes e Discentes participantes da dinâmica final do workshop "Planejar com a paisagem": uma alternativa para se pensar o planejamento. Fonte: arquivo do autor, 2019. 


\section{CONSIDERAÇÕES FINAIS}

O ponto de partida para a pesquisa de mestrado que levou à produção desta dissertação foi a conflituosa relação entre rios e cidade - e entre meio físico e processos de ocupação urbana - em Presidente Prudente, cidade média do interior paulista. Uma vez que a história de uma cidade é a "história de sua produção continuada" (SANTOS, 1994, p.71), esse trabalho procurou entender o núcleo urbano de Presidente Prudente e sua paisagem atual a partir da descrição dos processos históricos - de surgimento, crescimento, expansão e produção urbanos - tendo em mente um recorte: a Bacia Hidrográfica do Córrego do Veado. Sendo esta a bacia hidrográfica sobre a qual se deu o maior desenvolvimento do município, apresentando-se completamente inserida na malha urbana atual, procurou-se explicitar os conflitos para, em diálogo com questões inscritas nas lógicas contemporâneas de planejamento e projeto para o território e sua paisagem, investigar e descrever, elencar alternativas, ensaiar metodologias e revelar potencialidades para a construção de um futuro mais sustentável.

Assim, o primeiro capítulo deste trabalho constatou que a relação entre rios e cidade, que era originalmente harmônica e muitas vezes de dependência, passou, a partir do crescimento e explosão populacional das cidades, a uma relação conflituosa. Evidenciou que se trata de um conflito construído e ratificado por ações e políticas de planejamento urbano, aliados ao anseio humano por dominar a natureza através da técnica. Neste processo de construção da vida urbana, cada vez mais caótica e miserável, cidade e natureza foram então colocadas como se fossem entes separados, uma contra a outra.

A água potável para abastecimento e consumo não depende mais necessariamente dos rios que cortam a cidade, a técnica é capaz de buscá-la a distâncias prodigiosas, mas não sem custos, econômicos e ambientais; as rodovias, e não mais os rios e ferrovias, passam a conectar pessoas e lugares, o crescente protagonismo do carro altera a fisionomia das paisagens; o crescimento populacional e processos industriais contribuem para o mau-cheiro e poluição dos cursos d'água. Por sua vez, especificamente em relação à drenagem e circulação, a expansão e produção do espaço urbano impermeabilizam cada vez mais o território; enchentes e inundações tornam-se frequentes; o domínio técnico à época entendeu os cursos d'água como canais de drenagem; os fundos de vale, já negligenciados e entendidos 
como fundos da cidade, ganharam então novo protagonismo, mas como possíveis corredores de trânsito, na tentativa de resolver os problemas de circulação da nova forma urbana das cidades, caracterizadas por um modelo centro-periférico; vias marginais ou até mesmo sobrepostas aos córregos e rios são então construídas: nesse contexto, ocorrido em boa parte das cidades a partir da década de 60 do século XX, o processo de ruptura (GORSKI, 2010) dos rios com a cidade está completo. Vistos como barreiras e entrave ao desenvolvimento, os cursos d'água são então canalizados e tamponados; desaparecem dos mapas e se dissolvem em meio à paisagem transformada pelo homem; tornam-se invisíveis (SPIRN, 1995) na cidade e no imaginário da população.

Ao abordarmos no primeiro capítulo as questões relativas a urbanização e planejamento urbano no Brasil, vimos também que entre as décadas de 1920 e 1930 o índice de urbanização do país triplica e que, atrelada aos processos de industrialização, a década de 1930 representaria um momento de mudanças políticas, econômicas e sociais que provocaria também uma mudança estrutural na governança, com a instauração do planejamento urbano com parte da agenda do Estado. Como relatado por Monte-Mór (2008, p. 34), "vão sendo buscadas, na experiência do mundo desenvolvido, as abordagens existentes para os problemas gerados" e se difunde no Brasil, um modelo racional funcionalista que prima pelo zoneamento e termina por privilegiar o transporte sobre rodas. Na periodização elaborada por Villaça (1999), é a partir da década de 1930 que se tem início um planejamento integrado que busca solucionar - através de técnicas e métodos - os problemas gerados pelo crescimento das cidades brasileiras.

A partir de então, e mais especificamente entre o período 1965-1971 caracterizado por Villaça (1999) como o dos superplanos - através de entes públicos, de projetos ligados a universidades, ou mesmo instituições privadas, diversos órgãos relacionados à questões urbanísticas e de planejamento passariam então a desenvolver Planos Diretores para diversos municípios, impactando também Presidente Prudente, a cidade analisada nesta pesquisa.

Em relação aos conflitos entre meio físico e processos de ocupação, e entre rios e cidade, este período corresponde à fase das canalizações e das avenidas de fundo de vale na cidade de São Paulo, sendo consolidada no Plano Urbanístico Básico (1968), que "recomendava o uso dos vales como suporte das avenidas, em função do baixo custo e da topografia suave" (OSEKI; ESTEVAM, 2006). Tornando-se principal 
polo econômico do país, São Paulo tornar-se-ia também modelo e vetor para as transformações urbanas e planos: a transformação dos fundos de vale e margens dos cursos d'água em avenidas iria se replicar em diversas cidades, com destaque para os principais polos regionais no interior do estado. Em Presidente Prudente, as vias marginais no fundo de vale do Córrego do Veado, contíguas ao Parque do Povo, são exemplos de planos desta época que foram postos em prática.

Outro ponto importante discutido no decorrer do trabalho é a questão legislativa relacionada à proteção dos cursos d'água e suas margens: apenas em 1965, com a aprovação do Código Florestal, é que se viria a demarcar a proteção para "áreas de preservação permanentes", com a função de resguardar a paisagem e recursos hídricos; ainda assim, não havia uma legislação que abrangesse os rios e suas margens em áreas urbanas, e nesse período, passou-se a utilizar o Código Florestal como parâmetro.

Apenas em 1979, com a Lei ํㅜ 6766, dispondo sobre o parcelamento do solo urbano, é que se previu a demarcação de uma faixa de proteção de quinze metros para cada lado dos cursos d'água, nos rios e córregos das novas áreas que viriam a ser loteadas e parceladas. Portanto, enfatiza-se que à época de aprovação das referidas leis, e mesmo anteriormente, muitas cidades brasileiras encontravam-se em franco crescimento e expansão, com núcleos urbanos e centros consolidados; assim, o conflito com os rios estava sendo construído, ou já estava instaurado em muitas cidades.

O primeiro capítulo realiza uma abordagem que relaciona as cidades médias paulistas e os modelos desenvolvidos na metrópole. Após um processo de surgimento e estruturação dessas cidades, a ligação rodoviária com a capital e os planos e processos de industrialização - visando à concentração populacional e desenvolvimento locais e também à desconcentração industrial na capital do estado - provocaram o crescimento e expansão da malha urbana das mesmas, refletindo os processos de produção do espaço encontrados na metrópole e grandes cidades: condomínios fechados, modelo de expansão centro-periférico, eixos comerciais, surgimento de novas centralidades, distritos industriais, shopping centers, entre outros.

A homogeneização dos processos e suas paisagens, compreendidas como possibilidade de estabelecimento de paralelos entre metrópoles e cidades médias, relaciona-se também aos conflitos entre cidade e natureza e a ocupação do território 
e o meio físico: são encontrados nas cidades médias rios canalizados, tamponados, avenidas em fundos de vale, supressão de vegetação, desrespeito às áreas de preservação permanentes. A forma urbana das cidades e a escala dos processos é diferente, mas a morfologia indica similaridades e congruências entre os planos e processos de planejamento e a produção do espaço urbano que resultam nas relações conflituosas estudadas e discutidas por este trabalho.

O segundo capítulo apresenta uma outra chave de pensamento: a de que é possível planejar as cidades e espaços livres pensando a partir dos processos naturais e considerando o meio físico, em um planejamento ecossistêmico com a paisagem, evitando o conflito. O capítulo apresenta modelos e projetos, que vão desde cidades a sistema de parques, que foram desenvolvidos já no final do século XIX e durante o século XX, pensando-se em uma resolução para o caos e problemas gerados nas áreas urbanas em função do fenômeno da industrialização e de como esta afetou o acesso aos recursos naturais e causou a insalubridade de muitas cidades.

Autores nos auxiliaram nesse percurso de construção de uma possível convergência entre desenvolvimento e natureza: para Geddes (1994), as cidades apresentavam-se miseráveis e sua saúde, bem como da população, dependia de um maior acesso à natureza, ao campo, e também de uma maior participação destes no ambiente urbano. O modelo Cidade-Jardim, proposto por Ebenezer Howard no final do século XIX, idealizava a integralização entre cidade e campo, urbano e rural, em um modelo de cidade-social autossustentável, regida por seus espaços livres. As cidades e outras propostas baseadas no modelo - bairros no subúrbio e loteamentos, por exemplo - de fato apresentam desenho urbano em consonância com as linhas do relevo, considerando um processo de ocupação menos conflituoso com o meio físico, além da valorização dos parques, jardins e daquilo que seria chamado contemporaneamente de caminhabilidade.

No segundo capítulo, descrevemos também, através de Spirn (1995) e o caso de Boston (EUA), como as intervenções humanas na paisagem podem resultar em situações catastróficas para a vida urbana e como um posterior processo de planejamento pautado pela valorização das características físico-naturais do território pode reconverter a situação de conflito. Assim, apresentamos os projetos desenvolvidos por Frederick Law Olmsted para um sistema de parques para Boston e que se configuraram em um planejamento sistêmico dos espaços livres da cidade, 
atuando no controle de enchentes e na qualidade da água e promovendo espaços de recreação e lazer e o desenvolvimento de modais de transporte coletivo. Tem-se na figura e trabalhos de Frederick Law Olmsted, além da fundação do campo profissional da Arquitetura da Paisagem, as bases que justificam que o planejamento urbano a partir dos processos naturais e ecológicos podem resolver os conflitos entre os processos de ocupação e o meio físico e também que este mesmo planejamento pode recuperar paisagens alteradas pelo homem.

Como observado e descrito nos dois primeiros capítulos do trabalho, o campo disciplinar da arquitetura da paisagem, embora tão antigo quanto o próprio surgimento do urbanismo como disciplina, não se apresentou como o principal norteador das ações de planejamento no mundo moderno, que priorizou modelos alicerçados na racionalidade funcional. Porém, os projetos, pesquisas e metodologias desenvolvidas na área continuaram em atividade e retomaram sua força e importância a partir da ênfase na dimensão ambiental e sustentável propagadas no decorrer da segunda metade do século $X X$.

Tendo em vista os desdobramentos e atualizações frente ao planejamento com a paisagem no século $\mathrm{XX}$, apresentou-se no segundo capítulo as metodologias, projetos e contribuições desenvolvidos por importantes figuras do campo disciplinar da Paisagem, McHarg (1969) e Hough (1998) que, juntamente com Spirn (1995), descrevem processos e ações pensando na natureza como uma totalidade, além das propostas mais recentes que entendem a infraestrutura verde como um conceito e intervenções projetuais que possuem baixo impacto, mas alto desempenho, reunindo as especificidades e qualidades de diferentes campos disciplinares e áreas profissionais para otimizar a vida em meio urbano. Uma vez que, como apresentado por meio da obra de Hough (1998), é impossível dissociar o meio ambiente construído do meio ambiente natural em nossa realidade atual, frente a tantas transformações promovidas pela vida humana.

O trabalho apresentou o pioneiro lan McHarg (1969), cujo desenvolvimento de metodologia de leitura e análise da paisagem revolucionaram o planejamento de regiões. Trabalhando com o cruzamento de informações e suas sobreposições, a investigação gera uma cartografia síntese, ou mapa de aptidões, endereçando a melhor ocupação e possíveis usos para os espaços e território. McHarg desenvolveu também em seu método um corte fisiográfico do projeto, caracterizando a paisagem local e suas potencialidades e propondo cenários possíveis. Dos aspectos físicos aos 
sociais, de projetos locais a regionais, a metodologia do autor evidencia a possibilidade de se trabalhar em diferentes escalas, transitando por elas. Este aspecto é fundamental nos processos de projeto com a paisagem, principalmente naqueles relacionados às bacias hidrográficas.

O recorte de investigação alicerçado sobre a bacia hidrográfica é fundamento para o campo disciplinar que a toma por unidade de paisagem. Desse modo Hough (1998), ao apresentar o projeto para o Rio Don (Canadá), parte de sua bacia hidrográfica, e nos mostra a reconversão de um rio urbano e sua paisagem através de um processo de planejamento que procurou tornar aparente os processos que sustentam a vida (HOUGH, 1998); a ideia que é preconizada pelo autor tem uma dimensão cultural fundamental que preconiza a participação da população: o planejamento e o processo de projeto e implementação são base para a reconversão da população em sua relação com a natureza: "O princípio da visibilidade [...] é portanto, crítico para alcançar um comportamento ambiental responsável" (HOUGH, 1998, p. 48).

O caso do Rio Don é emblemático, uma vez que apresenta similaridade aos casos de muitos rios em cidades brasileiras: a original área degradada, poluída e desvalorizada, vista como barreira e entrave ao crescimento, recebe projeto para sua bacia, entendendo-a como uma unidade de paisagem. Essa ação integradora em muitas dimensões permitiu a ressignificação do rio para a cidade e possibilitou seu reencontro com a população - além do restabelecimento de sua biodiversidade, recuperação dos meandros, criação de lagos e áreas alagáveis, e proposição de usos mistos para seu entorno - aliando a prática de frequentar os espaços à ideia de promover segurança e aumentar o contato dos frequentadores e moradores com os processos ecossistêmicos.

Após estabelecer-se um panorama dos processos históricos de planejamento e das relações entre rios e cidade no primeiro capítulo e abordar-se, no segundo capítulo, os processos e metodologias praticados por outra chave de pensamento que entende a possibilidade de planejar sua paisagem a partir dos processos ecossistêmicos - adentra-se à pesquisa sobre a cidade de Presidente Prudente e o recorte escolhido: a Bacia Hidrográfica do Córrego do Veado.

Assim, os três últimos capítulos do trabalho estabelecem relações com as temáticas abordadas nos dois primeiros, porém contextualizando e relacionando à realidade local de uma cidade média. O terceiro capítulo apresenta o surgimento e 
crescimento de Presidente Prudente, descrevendo os processos de planejamento e ocupação do território que provocaram os conflitos entre rio e cidade. O quarto capítulo apresenta uma radiografia do processo específico de ocupação da Bacia Hidrográfica do Córrego do Veado. Por meio de comparações de imagens de satélite e fotos aéreas, evidencia as relações rio, cidade e espaços livres, do passado à configuração atual; em paralelo, discute documentos e as políticas de planejamento que ainda são pautadas na canalização dos córregos urbanos em Presidente Prudente. O quinto capítulo aborda, em referência às metodologias e modelos discutidos no segundo capítulo, uma proposta metodológica para projetar a paisagem - elegendo a bacia hidrográfica como unidade -, e que foi desenvolvida no formato de um workshop juntamente com alunos do curso de graduação em arquitetura e urbanismo da FCTUNESP em Presidente Prudente.

O trânsito de escalas que os três últimos capítulos realizam, a saber, do plano ao desenho urbano, iniciam-se pelas questões históricas relacionadas à Presidente Prudente, sua origem e desenvolvimento. Com base em toda a bibliografia e materiais analisados, observa-se que o desenvolvimento da região ocorreu pela intenção de ocupar o território, portanto como uma política governamental: as terras eram desbravadas, as matas derrubadas, lavouras implementadas, população fixada. Assim, o nascimento do núcleo urbano de Presidente Prudente, em 1917, também está ligado à questão fundiária, com a implementação de duas vilas - por dois diferentes coronéis - que funcionavam como base para os compradores e também como entreposto de produtos.

A linha férrea, que dividia as duas vilas, fornecia conexão direta com a capital do estado e foi responsável pelo desenvolvimento da região, fixando população e permitindo o escoamento das produções de café e algodão, entre outros produtos agrícolas. Nas décadas seguintes, a população continuava a crescer, indústrias se instalariam na cidade - como, por exemplo, as Indústrias Reunidas Fábricas Matarazzo (IRFM) em 1937 - e a mancha urbana, constituída sobre o espigão do relevo, passaria a se expandir em direção aos fundos e vale, iniciando os primeiros conflitos entre relevo, cursos d'água e a implantação do traçado urbano e ocupação do território. Sem suporte legislativo, urbanístico e ambiental, relacionado aos cursos d'água, e, em especial, na ausência de uma cultura alternativa àquela que construiu o território transformando os rios em galerias de água subterrânea, os 
processos de ocupação e produção do espaço invisibilizaram nascentes e os trechos iniciais de alguns córregos de Presidente Prudente já nas décadas de 1950.

Com as mudanças políticas estruturais e reformas administrativas advindas a partir da década de 1930, e difundidas também no decorrer das décadas posteriores, inicia-se um processo de planejamento urbano e do território por parte do governo, promovendo maior autonomia municipal e também a regionalização do estado, com a instalação de núcleos de serviços e atendimento em cidades que foram definidas como sedes de suas regiões. Os planos rodoviários e de industrialização no interior contribuiriam para fixação de população e desenvolvimento dos municípios.

Presidente Prudente é então oficializada como capital regional do oeste paulista e ganha destaque na CIBPU como possível polo industrial: a pedido da Comissão, é realizado o "Projeto de Um Distrito Industrial", em 1966, que tinha como proposta a fixação de população e desenvolvimento econômico regional a partir de um polo de desenvolvimento que já possuía infraestruturas: ferrovia, rodovias e proximidade a grandes rios, como Paraná e Paranapanema, além de crescimento demográfico. Para que o projeto se concretizasse e fossem atendidas também as normativas governamentais estaduais e federais para a provisão de recursos financeiros, a cidade deveria apresentar e aprovar seu Plano Diretor. Vinculado à época dos Superplanos - na divisão proposta por Villaça (1999) -, Presidente Prudente teria seu primeiro plano diretor elaborado entre os anos de 1968 e 1969 embora viesse a ser aprovado apenas em 1973. Desenvolvido pelo CPEU, ligado à Universidade de São Paulo, em conjunto com a Prefeitura Municipal e a Associação dos Arquitetos e Engenheiros da Alta Sorocabana e visando ao atendimento da nova Lei Orgânica dos Municípios, o Plano Diretor reflete um momento singular no qual as questões eram tratadas por várias instâncias técnicas e governamentais, procurando assegurar a efetividade do planejamento.

As monografias produzidas como bases para os planos apresentam uma investigação completa, na forma de diagnósticos, das questões territoriais, infraestruturais, econômicas e sociais para a cidade, propondo ações e projetos que teriam impacto efetivo no desenvolvimento da mancha urbana e na caracterização de Presidente Prudente como uma capital regional.

Diferentemente do modelo de planejamento racional funcionalista, que se enraizava pelo país como a principal corrente de planejamento e resolução das problemáticas, o CPEU, por estar vinculado à cadeira de planejamento da Faculdade 
de Arquitetura e Urbanismo da Universidade de São Paulo, apresentava influência de outros modelos e chaves de pensamento, como as experiências inglesas com as Cidades Novas e o conceito das unidades de vizinhança.

Assim, o documento final do Projeto de Um Distrito Industrial propõe que sobre o fundo de vale do Córrego do Veado, ainda desocupado à época, fosse construída uma avenida central e que em suas extremidades estivessem localizados os distritos industriais - um existente e outro proposto. Porém, além de apresentar a avenida, o documento vai além e propõe também a construção de um centro esportivo no local, atendendo às atividades de lazer e recreação da população.

Em relação aos espaços livres, os planos, especialmente o Plano Diretor, indicam a preservação paisagística dos fundos de vale, além da criação de "faixas verdes, bem sombreadas [...] passando a ter uma função mais orgânica e ativa no conjunto da cidade, junto às quais se instalariam os equipamentos urbanos" (Projeto de um Distrito Industrial para Presidente Prudente, 1966, p. 120). Assim, pode-se supor que o planejamento proposto pelo CPEU foi fundamental para que o Parque do Povo viesse a ser construído nos anos seguintes, nesse mesmo trecho central entre as pistas da nova avenida central. Embora as regiões de cabeceiras localizadas na área central já estivessem impermeabilizadas nesta época, o parque se tornaria uma grande área permeável para toda a bacia, além de consagrar-se como principal área de esportes, lazer, recreação e eventos da cidade; um parque como espaço público cultural e social.

Nos córregos já consolidados pela ocupação urbana - Córrego Água Bôscoli e Córrego do Bacarin - a aprovação do Plano Diretor proporcionou a vinda de recursos do Programa CURA (Comunidade Urbana para Recuperação Acelerada) que tiveram como objetivo principal na cidade as obras de drenagem e canalização de córregos, transformando-os em galerias de concreto, tamponados.

Apenas em 1979, com a Lei Lehmann, é que os novos loteamentos passariam a contar com áreas de proteção permanentes aos rios e suas margens. Considerando a legislação e as mudanças no mercado imobiliário apresentadas em Presidente Prudente a partir da década de 1970, mostrou-se, através de mapas e imagens de satélite, o impacto na forma urbana da cidade, que passou de uma mancha urbana compacta e consolidada a uma mancha urbana dispersa, mas que tem salvaguardada parte das áreas de proteção permanente de seus córregos nos loteamentos aprovados a partir de 1979 . 
$\mathrm{Na}$ área central da cidade - região de nascentes dos cursos d'água que compõem a bacia hidrográfica do Córrego do Veado - porém, os córregos apresentam-se invisíveis e o território, em quase sua totalidade, impermeabilizados. Como reflexo, são frequentes os conflitos entre rios e cidade, com enchentes e inundações e os rios tornando-se visíveis e entendidos como problemática principal. Culpa-se a natureza e seus processos, mas pouco se avalia o impacto das transformações e alterações humanas no território e, consequentemente, na paisagem.

Adentrando às questões relativas à Bacia Hidrográfica do Córrego do Veado, recorte da pesquisa, o trabalho apresentou as justificativas para sua escolha; entre elas: por ser, atualmente, uma bacia hidrográfica completamente urbana e sobre a qual desenvolveu-se a maior parte da cidade; por apresentar $91 \%$ de seus cursos d'água com intervenções; por ser a principal região de conflitos e problemáticas entre rios e cidade e entre o meio físico e os processos de ocupação; e por já se constituir em lugar de grande sociabilidade; quer-se ampliar também, potencialidades para 0 desenvolvimento de projetos e planejamento que possam configurar uma nova relação da população com os processos naturais e ecossistêmicos, conforme demonstrado nos registros históricos e teóricos apresentados no segundo capítulo e que nos servem como referência de uma chave de pensamento e planejamento possíveis.

Assim, o quarto capítulo, ao apresentar os córregos e processos históricos de ocupação de seu entorno e fundos de vale, evidenciando a supressão de cursos d'água, impermeabilização excessiva do solo, canalização, cercamento das áreas de APP, transformação de margens e fundos de vale em avenidas e vias, apresenta uma lógica de tratamento dada aos cursos d'água que foi, e ainda é, uma política de planejamento vigente em muitas cidades brasileiras, e não apenas no município pesquisado. Trata-se de uma dimensão local que dialoga com uma prática nacional, a partir de ações realizadas sobre os rios urbanos em todo o país e que se tornaram referenciais.

Como apresentado, canaliza-se os córregos da Bacia Hidrográfica do Córrego do Veado desde o início dos anos 1950, quando o desenvolvimento da malha urbana e os processos de ocupação e produção do espaço entraram em conflito com o meio físico. As canalizações não continuaram a ser realizadas em um modelo fechado, de tamponamento dos córregos, apenas porque houve intervenção do Ministério Público 
Ambiental, através da Promotoria do Meio Ambiente, que criou, em 2005, a partir de Presidente Prudente, uma normativa com abrangência estadual recomendando a não outorgar canalizações fechadas em rios, a menos que, além das razões técnicas, sejam casos excepcionais em que haja justificativa de utilidade pública ou interesse social para tais atos.

No quarto capítulo, ao se compararem as imagens que apresentam os cursos d'água e a ocupação de seus entornos em diferentes temporalidades, é possível observar que, no intervalo apresentado - entre meados da década de 1970 e 2019 houve um ganho considerável de vegetação e massas arbóreas, principalmente nas faixas referentes às áreas de preservação permanente dos córregos e que estas, salvo algumas exceções, foram respeitadas.

Percebendo um potencial sistema de espaços livres que as imagens conformam, nota-se a possibilidade de ser elaborado um planejamento com a paisagem, tirando partido do sistema formado por esses "corredores verdes e azuis" em uma bacia hidrográfica que é completamente urbana.

O quinto capítulo, então, apresenta um ensaio ocorrido em um workshop realizado em Presidente Prudente, parceria UNESP - USP, com alunos do curso de arquitetura e urbanismo, que propõe sobre a bacia do Córrego do veado uma alternativa para se pensar planejamento, planejando com a paisagem, ecossistemicamente, através da metodologia desenvolvida por (SCHENK; MEDEIROS, 2016) com base nas teorias e referenciais de projeto (MCHARG, 1969; SPIRN, 1995; HOUGH, 1998; GORSKI, 2010).

Parte-se do contexto histórico de uma chave de pensamento que alicerça 0 planejamento urbano a partir da paisagem, pioneiramente ainda no século XIX, para o planejamento atual da paisagem, evidenciando que aquela mesma chave de pensamento, atualizada, pode ser a solução para muitos dos conflitos e problemáticas apresentados na realidade atual de nossas cidades.

Elegendo a bacia hidrográfica como unidade de paisagem, consegue-se abrangência e efetividade das ações sobre todo seu território, seja ele local ou regional, rural ou urbano. O método projetual pode então, a partir daquela unidade, ampliar sua atuação, conectando-se a outras bacias hidrográficas e seus espaços livres: é uma ação em rede, formando um sistema pensado a partir de chaves que articulam infraestrutura e sociedade: drenagem, mobilidade, diminuição da temperatura, qualidade do ar, lazer e descanso. 
Trata-se, portanto, de uma ação que pode contribuir para a constituição de espaços qualificados que tenham suas questões infraestruturais contempladas de modo a gerar a vida e alicerçar a dimensão sócio-cultural desses lugares. A perspectiva é contribuir no desenvolvimento de políticas públicas de planejamento, projeto e atuação que possam partir da escala local e suas particularidades e atender a toda uma região. Para isso, é necessário que ocorra a articulação entre as diferentes instâncias - governamentais, legislativas e sociais.

Uma vez mais, utilizando-se da fala de Sposito (2009) apresentada no primeiro capítulo:

\begin{abstract}
No caso das cidades pequenas e médias, esta interface é muito mais forte, porque são cidades com níveis menos amplos de interações. São cidades que, a meu ver, ainda nos possibilitam, pelo tamanho que têm, um tratamento mais adequado da natureza, bem como exigem reconhecimento de uma consciência maior sobre o fato de que a cidade é natureza, para superar aquela ideia de que a natureza está fora cidade. Então quando eu falo par de articulação não é a cidade de um lado e a natureza de outro, mas é a própria compreensão de que a cidade é natureza e de que, sem sombra de dúvidas, são os processos de produção do espaço urbano os que mais estão interferindo, desconhecendo, negligenciando a dinâmica dos processos naturais. (SPOSITO, 2009, p. 17-18, grifo nosso)
\end{abstract}

Esta pesquisa procurou evidenciar esses processos - de ocupação do território, de produção do espaço, da construção do conflito entre meio físico e processos de ocupação, entre rios e cidade, entre cidade e natureza - para uma cidade média, Presidente Prudente; apresentando também alternativas, as potencialidades de se planejar (com) a paisagem.

Retomando Besse (2014) e considerando a polissemia do conceito de paisagem - uma construção social; a expressão de cultural de uma sociedade; a organização espacial de uma sociedade em certa temporalidade; uma experiência fenomenológica - tem-se na figura do arquiteto da paisagem um profissional articulador destas complexidades, uma vez que este reúne as bases e questões dos diferentes campos e seria o responsável por transformar a paisagem - projetando possibilidades - a partir do que ele próprio compreende da mesma - em uma leitura das potencialidades - e todas as suas relações.

Como relata Hough (1998), é necessário que novos processos cumulem os lugares das cidades de significado, com projetos que transformem os corpos de água, a também chamada rede azul, em algo mais que galerias, que se façam visíveis os 
processos que sustentam a vida, para que, então, passem a ser preservados e desejados como parte de uma política pública de planejamento urbano - que é também, sem dúvidas, uma política de planejamento com a paisagem.

Os espaços livres, seu planejamento e projeto são a resposta bastante consistente. As cidades médias são uma possibilidade. O arquiteto da paisagem potenciamente articula esses processos, materializando sob a forma de desenho essas muitas demandas e análises numa ação integradora que procura, uma vez mais unir desenvolvimento e natureza. 


\section{REFERÊNCIAS}

ABREU, Dióres Santos. Formação histórica de uma cidade pioneira Paulista: Presidente Prudente. Presidente Prudente: FFCLPP, 1972.

ALVES, A. O. Planejamento ambiental urbano na microbacia do Córrego Colônia Mineira. 2004. 128 f. Dissertação (Mestrado em Geografia) Faculdade de Ciências e Tecnologia de Presidente Prudente - Universidade Estadual Paulista.

AMORIM, Margarete Cristiane da Costa Trindade. Análise ambiental e qualidade de vida na cidade de Presidente Prudente/SP. Dissertação de mestrado. Presidente Prudente: UNESP - FCT, 1993.

ANDRADE, Carlos Roberto Monteiro de. A peste e o plano. O urbanismo sanitarista do engenheiro Saturnino de Brito. 1992. 282 f. Dissertação (Mestrado) - Faculdade de Arquitetura e Urbanismo, Universidade de São Paulo, São Paulo, 1992.

BASTIDE, Roger. 1978. Brasil, Terra de Contrastes. São Paulo, DIFEL.

BERQUE, A. Médiance. De milieux en paysages. Montpellier: GIP Reclus, 1990.

BERNARDELLI, Maria Lúcia Falconi da Hora. Programa Cura III em Presidente Prudente: Uma porta para a cidade? In: SPOSITO, M. E. B. (org) Textos e Contextos para a Leitura Geográfica de uma Cidade Média. Presidente Prudente: UNESP, 2001.

BONZI, Ramon S. Andar sobre Água Preta: a aplicação da Infraestrutura Verde em áreas densamente urbanizadas. Dissertação (Mestrado), FAUUSP, 2015.

BORTOLO, Carlos Alexandre. Transformações no/do espaço urbano e a dinâmica da produção de um espaço público: um ensaio sobre o Parque do Povo em Presidente Prudente - SP. In: ACTA Geográfica, Boa Vista, v. 6, n. 11, p. 35-51, 2012.

BESSE, Jean-Marc. O gosto do mundo: exercícios de paisagem. Rio de Janeiro: Eduerj, 2014.

BIRKHOLZ, Lauro Bastos. Planos Diretores Municipais no Estado de São Paulo e sua Implantação.1964. Tese de Livre Docência. Faculdade de Arquitetura e Urbanismo, Universidade de São Paulo. São Paulo: 1964.

BORTOLO, Carlos Alexandre. O Parque do Povo em Presidente Prudente - SP: reflexões geográficas. In: Revista Percurso - NEMO, no 2, v. 5 - Maringá - p. 47-71, 2013.

BRASIL, 1965. Lei no 4.771. Institui o novo Código Florestal.

BRASIL, 1979. Lei n 6.766. Dispõe sobre o parcelamento do solo urbano e dá outras providências. 
BRASIL, 2012. Lei no 12.651. Dispõe sobre a proteção da vegetação nativa

BRITO, A.L.N.P et al. A difícil aplicabilidade da legislação de faixas marginais de proteção de rios urbanos: $O$ caso do município de Mesquita na Baixada Fluminense. II Seminário Nacional de APPs Urbanas, 2012, Natal.

CALDEIRA Teresa P. do Rio. Cidades de muros: crime, segregação e cidadania em São Paulo. São Paulo: Ed. USP, 2000

CAMPOS, Cândido Malta. Os rumos da cidade: urbanismo e modernização em São Paulo. São Paulo: Editora Senac São Paulo, 2002.

CANO, Wilson; GUIMARAES NETO, Leonardo. A Questão Regional no Brasil: traços gerais de sua evolução histórica. In: Pensamiento Iberoamericano. Economia PoliticaMadri: Instituto de Cooperation Iberoamericana, n. 10, p. 167-184, 1986.

CHOAY, F. El Urbanismo, Utopías y Realidades. Barcelona: Lumen, 1970.

CIBPU. Projeto de um Distrito Industrial para Presidente Prudente. São Paulo: CPEU/USP, 1966.

CORMIER, Nathaniel S.; PELLEGRINO Paulo R.M. Infraestrutura verde: uma estratégia paisagística para a água urbana. Revista Paisagem Ambiente, n. 25, São Paulo, FAU-USP, p. 127-142, 2008.

COSTA, L. M. S. A. Rios urbanos e o desenho da paisagem. In: COSTA, L. M. S. A. (Org.) Rios e paisagens urbanas em cidades brasileiras. Rio de Janeiro: PROURB/UFRJ, 2006.

CPEU. Plano Diretor de Presidente Prudente. São Paulo: CPEU/USP, 1969.

CULLEN, Gordon. Paisagem Urbana. São Paulo: Martins Fontes, 1983.

CUSTÓDIO, Vanderli; CAMPOS, Ana Cecília M. de Arruda; MACEDO, Silvio Soares; QUEIROGA, Eugênio F. Sistemas de Espaços Livres e forma urbana: algumas reflexões. Desenvolvimento, planejamento e governança, 2013, Recife. ENCONTROS NACIONAIS DA ANPUR, Anais... Revista da ANPUR v.15, p. 1-17. Disponível em: <http://www.anpur.org.br/revista/rbeur/index.php/anais/article/view/4429/4298>. Acesso em: 15 ago. 2017.

DAL POZZO, C. F. Fragmentação socioespacial em cidades médias paulistas: os territórios do consumo segmentado de Ribeirão Preto e Presidente Prudente / Clayton Ferreira Dal Pozzo. - Presidente Prudente: [s.n.], 2015

DEÁK, Csaba; SCHIFFER, Sueli Ramos (org.) O processo de urbanização no Brasil. São Paulo: EdUSP, 2004.

FAGUNDES, B. As águas da cidade de Presidente Prudente - SP - Brasil: memória e representação social. 2018. 367f. Tese (Doutorado em Geografia), Universidade 
Estadual Paulista, Faculdade de Ciências e Tecnologia, 2018. Disponível em: <http://hdl.handle.net/11449/157227>

FELDMAN, Sarah. Planejamento e zoneamento. São Paulo: 1947-1972. São Paulo, Edusp, Fapesp, 2005.

FELDMAN. Sarah. Instituições de urbanismo no Brasil na década de 1930: olhar técnico e dimensão urbano-industrial. 2008. Tese (Livre-docência) - Universidade de São Paulo, Escola de Engenharia de São Carlos, São Carlos, 2008.

FERNANDES, Ana. Urbanismo como política (1930-1945): formulações e experiências. In: Rezende, Vera (org) Urbanismo na Era Vargas: a transformação das cidades brasileiras. 01 ed. Niterói: Editora da Universidade Federal Fluminense, 2012, v.01.

FIREHOCK, Karen. A short history of the term green infrastructure and selected literature. 2010. Disponível em: <http://www.gicinc.org/PDFs/Gl\%20History.pdf> Acesso em: 07 de Abril de 2018.

FRANCISCO, A. M. Os desafios do planejamento urbano em áreas de fundo de vale consolidadas: o caso da microbacia do Córrego do Veado em Presidente Prudente, SP. In: Seminário Nacional Sobre Áreas De Preservação Permanente Em Meio Urbano: Abordagens, Conflitos E Perspectivas Nas Cidades Brasileiras, 2., 2012, Natal. Anais... Disponível em <http://anpur.org.br/app-urbana-2012/anais> Acesso em: 08 fev. 2019.

FRANCISCO, Arlete M. et al. Repensando os espaços da cidade: Diretrizes Urbanísticas para Áreas de Preservação Permanente Urbana Consolidadas. In: Seminário Nacional Sobre O Tratamento De Áreas De Preservação Permanente Em Meio Urbano, 2014, Belém. Anais... Belém: UFPA, 2014.

GARDIN, Cleonice. CIBPU: A Comissão Interestadual da Bacia Paraná-Uruguai no Planejamento Regional Brasileiro (1951-1972). Dourados, MS: Editora da UFGD, 2009. 244p.

GEDDES, Patrick. Cidades em evolução. Tradução de Maria José Ferreira de Castilho. Campinas, SP: Papirus, 1994.

GORSKI, Maria Cecília B. Rios e Cidades: ruptura e reconciliação. São Paulo: Senac, 2010.

HALL, Peter. Cidades do amanhã: uma história intelectual do planejamento e do projeto urbanos no século XX. São Paulo: Perspectiva, 1995. 550 p.

HIGUERAS, Esther. Urbanismo Bioclimático. Barcelona: Gustavo Gili, 2010.

HERZOG, Cecília Polacow. Cidade para todos: (re) aprendendo a conviver com a natureza. Rio de Janeiro: Mauad X: Inverde, 2013. 
HERZOG, C.P. ROSA, L. Z. Infraestrutura verde: sustentabilidade e resiliência para a paisagem urbana. In REVISTA LABVERDE/ Universidade de São Paulo. Faculdade de Arquitetura e Urbanismo, Departamento de Projeto. LABVERDE - Laboratório Verde - v.1, n.1 (2010), p. 134-154. São Paulo: FAUUSP, 2010.

HORA, Mara Lúcia Falconi da. Produção x apropriação do espaço urbano: o papel exercido pelo poder público no processo de "valorização" de áreas urbanas. O exemplo do Jardim Caiçara e da Vila Mathilde Vieira em Presidente Prudente-São Paulo /Mara Lúcia Falconi da Hora, Maria José Martinelli Silva. - Presidente Prudente, 1991

HOUGH, Michael. Naturaleza y ciudad. Barcelona: GG, 1998.

HOWARD, Ebenezer. Cidades-jardins de amanhã. Tradução: Marco Aurélio Lagonego, Introdução: Dácio Araújo Benedito Otoni. São Paulo: Hucitec, 1996.

INSTITUTO BRASILEIRO DE GEOGRAFIA E ESTATÍSTICA (IBGE). Sinopse do Censo Demográfico 2010. Rio de Janeiro: IBGE, 2011. Disponível em: < http://www.ibge.gov.br/home/estatistica/populacao/censo2010/default_sinopse.shtm> . Acesso em: 12 dez. 2017.

LE DANTEC, Jean Pierre. O Eclipse Moderno do Jadim. In: LEENHARDT, Jacques (org). Nos Jardins de Burle Marx. São Paulo: Perspectiva, 2000. p. 100-103

LEITE, José Ferrari. A Ocupação do Pontal do Paranapanema. São Paulo: Hucitec; Fundação Unesp, 1998.

LÉFÈBVRE, Henri. Espacio y política: El derecho a la ciudad, II. Barcelona: Ediciones península, 1972.

LEFEBVRE, H. The Urban Revolution. Translation of La Révolution urbaine by Robert Bononno. University of Minnesota Press. 2003

LUCCHESE, Maria Cecilia. Curam-se cidades uma proposta urbanística da década de 70. 2004. Dissertação (Mestrado em Estruturas Ambientais Urbanas) - Faculdade de Arquitetura e Urbanismo, Universidade de São Paulo, São Paulo, 2004. DOI:10.11606/D.16.2004.tde05112013-110903. Acesso em: 2019-03-11.

LYNCH, Kevin. A imagem da cidade. São Paulo: Martins Fontes, 1997.

MACEDO, S.; QUEIROGA, E.; GALENDER, F.; CAMPOS, A. C. DE; CUSTÓDIO, V.; DEGREAS, H.; GONÇALVES, F. Os Sistemas de Espaços Livres na Constituição da Forma Urbana Contemporânea no Brasil: Produção e Apropriação (QUAPÁSEL II). Paisagem e Ambiente, n. 30, p. 137-172, 30 jun. 2012. DOI: https://doi.org/10.11606/issn.23595361.v0i30p137-172

MAGNOLI, Miranda M. E. M. Espaços livres e urbanização: uma introdução a aspectos da paisagem metropolitana. 1982. 116 p. Tese (Livre-docência em 
Estruturas Ambientais Urbanas) - Faculdade de Arquitetura e Urbanismo, Universidade de São Paulo, São Paulo, 1982.

MAGNOLI, Miranda M. Espaço Livre - Objeto de Trabalho. Paisagem e Ambiente: ensaios. n. 21. São Paulo. p. 175 - 198. 2006

MARISCO, Luciane M. de Oliveira. Contribuição ao estudo do planejamento municipal no Brasil: o Plano Diretor de Desenvolvimento Integrado de Presidente Prudente (SP) de 1969. Presidente Prudente, 1997. Dissertação de mestrado em Geografia, UNESP, Presidente Prudente.

MARQUES, Cristiana A. P. Feltrin. Arquitetura em Presidente Prudente: três obras. São Paulo, 2011. 159 p. Dissertação de mestrado em Projeto de Arquitetura, Faculdade de Arquitetura e Urbanismo, Universidade de São Paulo, São Paulo, 2011.

MATOS. O. N. Café e Ferrovias: a evolução ferroviária de São Paulo e o desenvolvimento da cultura cafeeira. Campinas. Pontes, 1990.

MCHARG, Ian. Design with Nature. Jonh Wiley \& Sons Inc., 1992.

MENDONÇA, Vinicius Moura. Impactos pluviais na cidade de Presidente Prudente-SP. 2011. 1 CD-ROM. Trabalho de conclusão de curso (Bacharelado - Geografia) - Universidade Estadual Paulista, Faculdade de Ciências e Tecnologia, 2011. Disponível em: <http://hdl.handle.net/11449/119957>

MONTE-MÓR, Roberto Luís de Melo. Do urbanismo à política urbana: notas sobre a experiência brasileira. In: COSTA, G.M.; MENDONÇA, J. G. (Org.). Planejamento urbano no Brasil: trajetória, avanços e perspectivas. Belo Horizonte: Ed. C/Arte, 2008. p.31-65.

MOROZ-CACCIA GOUVEIA, I. C.; GOUVEIA, J. M. C. Estimativa de mudanças nas taxas de processos hidrodinâmicos em bacias hidrográficas urbanas: Contribuições da cartografia geomorfológica. In: XI Encontro Nacional da ANPEGE, № 11, 2015. Presidente Prudente. Anais do XI Encontro Nacional da ANPEGE, 2015, p. 10648-10659.

MOROZ-CACCIA GOUVEIA, I. C.; SILVA, N. R.; DERIVAÇÕES AMBIENTAIS. In: NUNES, J. O. R et al. (Org.). Atlas ambiental escolar de Presidente Prudente, São Paulo, Brasil. 1ed.PRESIDENTE PRUDENTE: Ed. do Autor, 2017, v. 1, ISBN (97885-60554-14-0). Disponível em: http://portaldoprofessor.fct.unesp.br:9000/

MUMFORD, Lewis. Planejamento Regional: uma nova tarefa. In: A Cultura das Cidades. Belo Horizonte. Editora Itatiaia, 1938.

NUNES, João O. R. et al. Atlas ambiental escolar de Presidente Prudente, São Paulo, Brasil. FCT-UNESP, Campus Presidente Prudente. ISBN: 978-85-60554-14-0. Disponível em: < http://portaldoprofessor.fct.unesp.br:9000/ > Acesso em: 18 de julho de 2018.

OSEKI, Jorge Hajime; ESTEVAM, Adriano Ricardo. A fluvialidade em rios paulistas. In: Rios e paisagens urbanas em cidades brasileiras [S.I: s.n.], 2006. 
OTTONI, Dácio A. B. Cidade-jardim: formação e percurso de uma ideia. Introdução a: HOWARD, Ebenezer. Cidades-jardins de amanhã. São Paulo: Hucitec, 1996.

PRESIDENTE PRUDENTE. Lei no 301, de 25 de maio de 1954. 1954. Dispõe sobre a declaração de utilidade pública a área aproximada de 17000 metros quadrados do buracão entre as ruas São Sebastião e Vitória. Disponível em http://www.presidenteprudente.sp.gov.br/site/leis_decretos.xhtml. Acesso em 20 de março de 2018

PRESIDENTE PRUDENTE. Decreto Municipal no 4417, de 16 de junho de 1981. 1981. Declara de utilidade pública imóveis a serem desapropriados para "obras de saneamento e urbanização do Buracão da Raposo Tavares. Disponível em http://www.presidenteprudente.sp.gov.br/site/leis_decretos.xhtml. Acesso em 17 de setembro de 2019

PRESIDENTE PRUDENTE, Prefeitura Municipal de Presidente Prudente está préselecionada para receber recursos do PAC 2. 2010. Disponível em: http://www.presidenteprudente.sp.gov.br/site/noticias.xhtml;jsessionid=363DDB87A7282432 A2567EB702D16FCE?cod=7844\&imprimir=true. Acesso em: 14 nov. 2019.

PRESIDENTE PRUDENTE, Prefeitura Municipal de. Prefeito lança Parque Ecológico do São Lucas com investimentos de $R \$ 3,3$ milhões. 2014. Disponível em: http://www.presidenteprudente.sp.gov.br/site/noticias.xhtml?cod=27073. Acesso em: 17 nov. 2019.

PRESIDENTE PRUDENTE. Lei Complementar no 230, de 20 de dezembro de 2018. 2018a. Dispõe sobre a Lei do Plano Diretor do Município, e dá outras providências. Disponível em http://www.presidenteprudente.sp.gov.br/site/leis_decretos.xhtml. Acesso em 03 de abril de 2019

PRESIDENTE PRUDENTE. Lei Complementar no 231, de 20 de dezembro de 2018. 2018b. Dispõe sobre a Lei de Zoneamento do Uso e Ocupação do Solo do município, e dá outras providências. Disponível em http://www.presidenteprudente.sp.gov.br/site/leis_decretos.xhtml. Acesso em 02 de abril de 2019

PRESIDENTE PRUDENTE. Lei Complementar nº 232, de 20 de dezembro de 2018. 2018c. Dispõe sobre a Lei de Parcelamento do Solo do Município, e dá outras providências. Disponível em http://www.presidenteprudente.sp.gov.br/site/leis_decretos.xhtml. Acesso em 02 de abril de 2019

PRESIDENTE PRUDENTE. Lei Complementar n² 233, de 20 de dezembro de 2018. 2018d. Dispõe sobre a Lei do Sistema Viário do município, e dá outras providências. Disponível em http://www.presidenteprudente.sp.gov.br/site/leis_decretos.xhtml. Acesso em 03 de abril de 2019

QUEIROGA, Eugênio $F$. Por um paisagismo crítico: uma leitura sobre a contribuição de Miranda Magnoli para a ampliação do corpus disciplinar do paisagismo. In: Paisagem e Ambiente: ensaios - no 21, São Paulo, p. 55-64, 2006. 
QUEIROGA, Eugênio F.; BENFATTI, Denio M. Sistemas de Espaços Livres Urbanos: Construindo um Referencial Teórico. In: Paisagem e Ambiente: Ensaios - no 24 (Especial ENEPEA 2006), São Paulo, pp. 81-88, 2007.

REIS FILHO, Nestor Goulart. Notas sobre urbanização dispersa e novas formas de tecido urbano. São Paulo: Via das Artes, 2006

SÃO PAULO (Estado). Ministério Público. Assunto: Canalização de córregos na cidade de Presidente Prudente - SP. Parecer técnico. Autos: PT no 439/05. Presidente Prudente, 11 nov. 2005a.

SÃO PAULO (Estado). Secretaria de Recursos Hídricos, Saneamento e Obras. Departamento de Águas e Energia Elétrica. [Outorgas - canalização]. São Paulo, 2005b. Requerimento de outorga de direito de uso de recursos hídricos ao Departamento de Águas e Energia Elétrica DAEE. Processo ㄲo 9400819, Provisória 9.

SANTOS, Milton. Cidade e Região nos países subdesenvolvidos. In: A cidade nos países subdesenvolvidos. Rio de Janeiro. Ed. Civilização Brasileira, 1965.

SANTOS, Milton. A Natureza do Espaço. Técnica e Tempo, Razão e Emoção. São Paulo: Hucitec, 1996.

SANTOS, Milton. Pensando o espaço do homem. São Paulo: Hucitec, 1997.

SANTOS, Milton. O tempo nas cidades. Cienc. Cult., São Paulo, v. 54, n. 2, p. 21-22, Oct. 2002. Disponível em <http:/cienciaecultura.bvs.br/scielo.php?script=sci_arttext\&pid=S000967252002000200020\&lng=en\&nrm=iso >. Acesso em 11 Mar. 2017.

SANTOS, Milton. A urbanização brasileira. São Paulo. EDUSP, 2005.

SAWADA, Fernando T. et al. Análise espaço-temporal do Parque do Povo de Presidente Prudente a partir de fotos aéreas e imagem orbital. Presidente Prudente, 2007. Monografia de conclusão de curso. Universidade Estadual Paulista, Faculdade de Ciências e Tecnologia de Presidente Prudente, 2007.

SCHENK, Luciana. B. M. Arquitetura da paisagem: entre o Pinturesco, Olmsted e o Moderno. Tese de Doutorado. São Carlos: EESC/USP, 2008.

SCHENK, Luciana Bongiovanni Martins; MEDEIROS, Givaldo Luiz. Bacia hidrográfica como unidade de paisagem: sistemas de espaços livres, cidade e meio ambiente. Anais.. Salvador: Universidade Federal da Bahia - Faculdade de Arquitetura e Urbanismo - FAUFBA, 2016.Disponível em: .https://enepeasalvador.wixsite.com/enepea2016/copia-artigos-aceitos

SCHUTZER, José Guilherme. Cidade e meio ambiente: a apropriação do relevo no desenho ambiental urbano. São Paulo: Edusp, 2012.

SILVA, Maria José Martinelli. O parque do povo em Presidente Prudente - SP. Dissertação de Mestrado em Geografia, Presidente Prudente, 1994. 
SILVA, N. R. da; MOROZ-CACCIA GOUVEIA, I. C. 100 Anos de urbanização e transformações na Bacia Hidrográfica Córrego Do Veado, Presidente Prudente (SP). Espaço em Revista, v. 19, n. 1. jan.jun. 2017. p. 21 - 37. ISNN: 1519-7816. 2017

SOBARZO, Oscar. A segregação socioespacial em Presidente Prudente: análise dos condomínios horizontais. Presidente Prudente, 1999. 213f. Dissertação (Mestrado em Geografia) - Faculdade de Ciências e Tecnologia, UNESP.

SPIRN, Anne W. O Jardim de Granito. São Paulo: Edusp, 1995.

SPIRN, A. W. The Language of Landscape. Yale University Press, 1998

SPOSITO, Maria Encarnação Beltrão. O chão em Presidente Prudente: a lógica da expansão territorial urbana. 1983. 230f. Dissertação (Mestrado em Geografia) Universidade Estadual Paulista, Instituo de Geociências e Ciências Exatas de Rio Claro, 1983.

SPOSITO, Maria Encarnação B. Expansão Territorial Urbana de Presidente Prudente. Recorte, n. 04, Presidente Prudente, 1995.

SAVÉRIO SPOSITO, Eliseu. Reestruturação produtiva e urbana no Estado de São Paulo. Scripta Nova. Revista Electrónica de Geografía y Ciencias Sociales. Barcelona: Universidad de Barcelona, 1 de agosto de 2007, vol. XI, núm. 245 (69). <http://www.ub.es/geocrit/sn/sn-24569.htm> [ISSN: 1138-9788]

SPÓSITO, M. E. B. Novas formas comerciais e redefinição da centralidade intraurbana. In: SPÓSITO, Maria Encarnação Beltrão (org). Textos e contextos para a leitura geográfica de uma cidade média. Presidente Prudente, 2001. p. 235-254

BELTRÃO SPOSITO, Maria Encarnação Beltrão. Reestruturação urbana e segregação socioespacial no interior paulista. Scripta Nova. Revista electrónica de geografía y ciencias sociales. Barcelona: Universidad de Barcelona, 1 de agosto de 2007, vol. XI, núm. 245 (11). <http://www.ub.es/geocrit/sn/sn-24511.htm> [ISSN: 1138-9788]. 2007.

SPOSITO, Maria Encarnação Beltrão. Cidades médias: reestruturação das cidades e reestruturação urbana. In: SPOSITO, Maria Encarnação Beltrão (org.). Cidades médias: espaços em transição. São Paulo: Expressão Popular, 2007c.

SPÓSITO, M. E. B. Para Pensar as Pequenas e Médias Cidades Brasileiras. Belém: Federação de Órgãos para Assistência Social e Educacional/FASE, Instituto de Ciências Sociais Aplicadas/UFPA, 2009.

TAVARES, J. Planejamento Regional no Estado de São Paulo: Polos, Eixos e a Região dos Vetores Produtivos. In: Anais do XVII ENANPUR. v. 17, n. 1. São Paulo, 2017. ISSN 19848781. 2017

TOLEDO, Benedito Lima. Prestes Maia e as Origens da Urbanismo Moderno em São Paulo. São Paulo, Empresa das Artes, 1996. 
TOPALOV, C; LEME, Maria Cristina da Silva. Saberes sobre a cidade: tempos de crise? Espaco e Debates, v.11, n.34, p.28-37. 1991.

TUCCI, C. E. M. Águas urbanas. In: Estudos avançados, São Paulo, v.22, n.63, 2008.

UNWIN, R. La Practica del Urbanismo. Una Introducion al arte de proyectar ciudades y barrios. Barcelona: Gustavo Gili, 1984.

VILLAÇA, Flávio. Uma contribuição para a história do planejamento urbano no Brasil. In: DEÁK, Csaba; SCHIFFER, Sueli Ramos (org.) O processo de urbanização no Brasil. São Paulo: EdUSP, 1999. p. 169 - 243. 